\title{
Geohydrology and Water Quality of the Durham Center Area, Durham, Connecticut
}

BY ROBERT L. MELVIN, JANET RADWAY STONE, PATRICK A. CRAFT, JOHN W. LANE, JR., AND BRUCE S. DAVIES 3D

U.S. GEOLOGICAL SURVEY

Water-Resources Investigations Report 94-4237

Prepared in cooperation with the U.S. ENVIRONMENTAL PROTECTION AGENCY

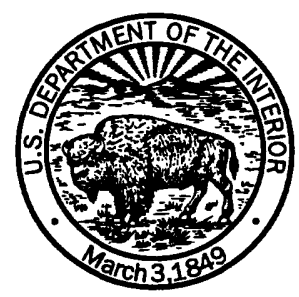

Hartford, Connecticut 1995 


\title{
U.S. DEPARTMENT OF THE INTERIOR BRUCE BABBITT, Secretary
}

\author{
U.S. GEOLOGICAL SURVEY \\ Gordon P. Eaton, Director
}

For additional information write to:

District Chief

U.S. Geological Survey

450 Main Street

Room 525

Hartford, CT 06103
Copies of this report can be purchased from:

U.S. Geological Survey

Earth Science Information Center

Open-File Reports Section

Box 25286, MS 517

Denver Federal Center

Denver, CO 80225 


\section{CONTENTS}

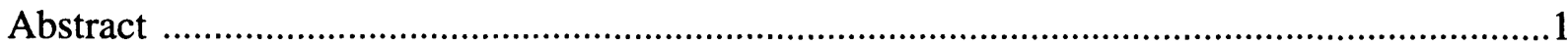

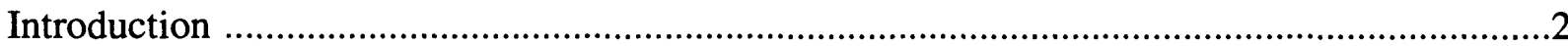

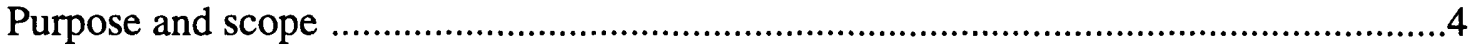

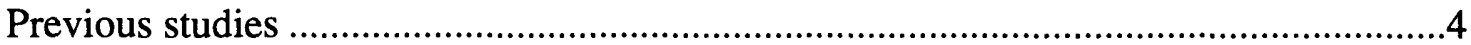

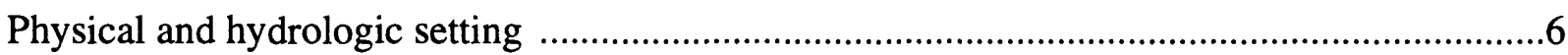

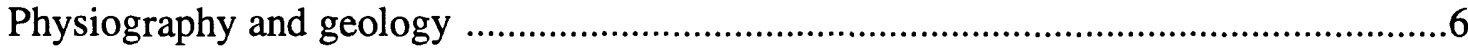

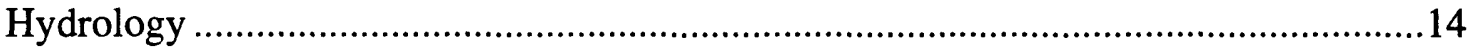

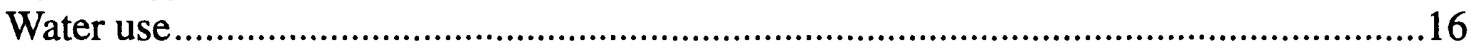

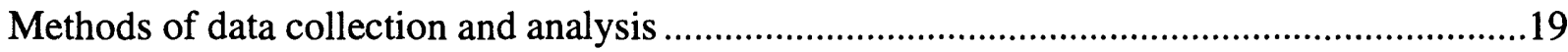

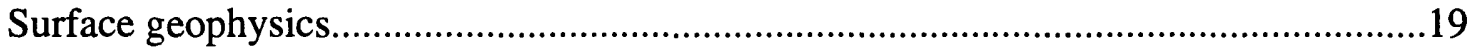

Azimuthal, square-array direct-current resistivity soundings ............................20

Square-array direct-current-resistivity traverses ................................................20

Very-low-frequency electromagnetic traverses..................................................20

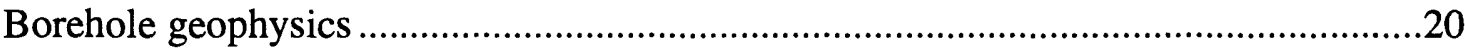

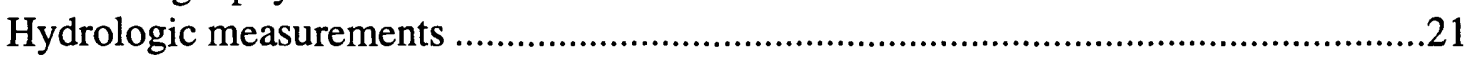

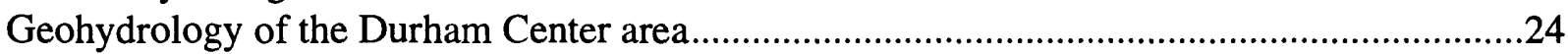

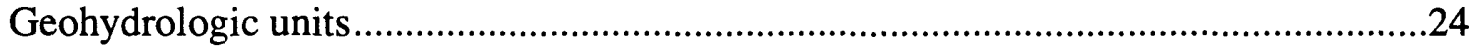

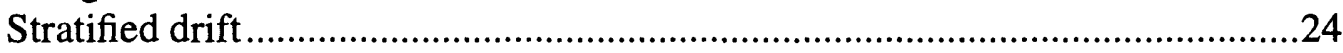

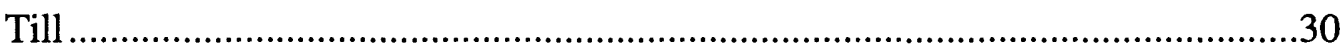

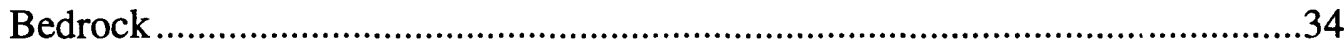

Stratigraphy, lithology, and mineralogy ...............................................34

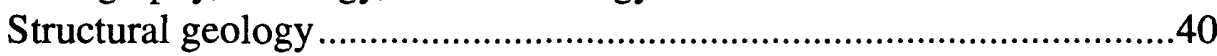

Hydraulic properties...................................................................................

Hydrologic models for the bedrock ..................................................52

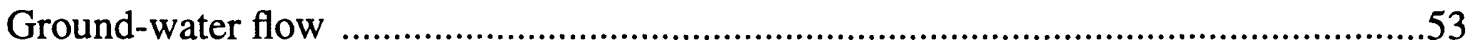

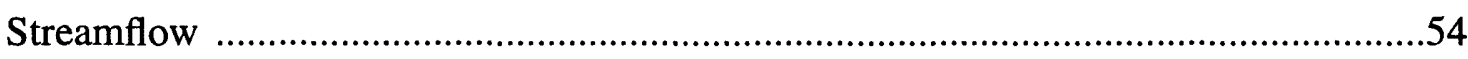

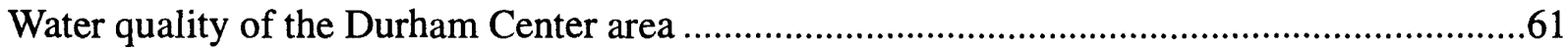

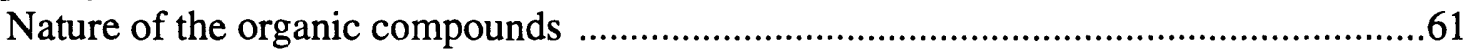

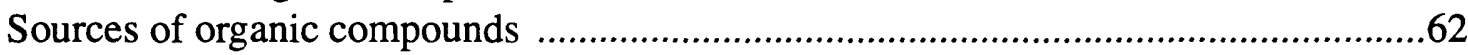

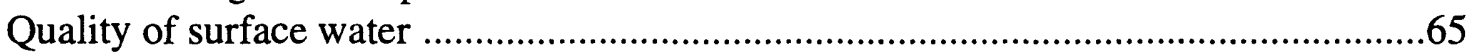

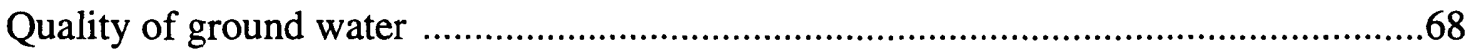

Conceptual model of the movement and fate of organic contaminants in ground water ............80

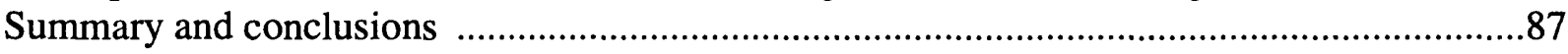

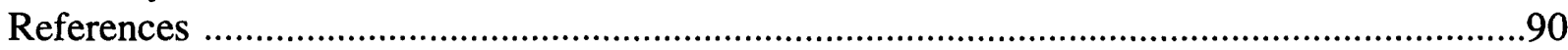

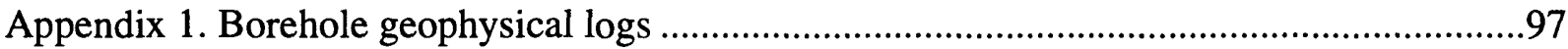




\section{FIGURES}

1. Map showing the location of the Durham Center area, Durham, Conn. ...................................3

2. Map showing the Coginchaug River basin, Conn. .................................................................

3. Maps showing:

a. Bedrock geology and bedrock-surface contours in the Durham Center area,

Durham, Conn ...............................................................................................

b. Surficial geology in the Durham Center area, Durham, Conn...................................10

c. Geologic section along A-A', Durham, Conn. ………............................................12

4. Graph showing average annual precipitation at Middletown, Conn., January 1962 -

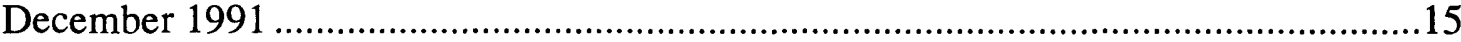

5. Graph showing distribution of yields from wells completed in different bedrock aquifers

in the lower Connecticut River basin.......................................................................17

6. Map showing idealized surface-water and shallow ground-water circulation pattern

in the Durham Center area, Durham, Conn. ..................................................................18

7. Map showing location of wells in and near the Durham Center area, Durham, Conn. ...........25

8. Map showing depth to bedrock at Durham Center, Durham, Conn. ......................................32

9. Graph showing water levels in U.S. Geological Survey observation well D-117,

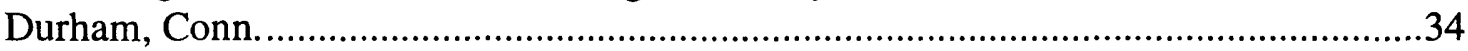

10. Lithologic logs of selected wells in the Durham Center area, Durham, Conn., interpreted from borehole-geophysical data .................................................................36

11. Geologic sections B-B' and C-C', Durham Center area, Durham, Conn. ............................38

12. Map showing locations of surface-geophysical surveys in the Durham Center area,

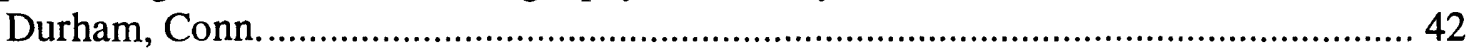

13. Graph showing mean terrain resistivity and anisotropy along square-array directcurrent resistivity traverse lines 1 and 2, Durham Center area, Durham, Conn.

14. Graph showing ratio of secondary to primary magnetic field along very-low frequency electromagnetic traverse line 5, Durham Center area, Durham, Conn.

15. Azimuthal plots of square-array direct-current resistivity sounding measurements made with 40-meter A-spacing at sites 1 and 2, Durham Center area, Durham, Conn.

16. Lower-hemisphere, equal-area net plot of the poles to fracture planes (A) and rose diagram showing frequency of observed strike directions of fractures (B), in the Durham Center area, Durham, Conn.

17. Graph showing apparent resistivity (A) and geoelectric sections (B) constructed from azimuthal, square-array direct-current resistivity soundings SQ-S1 and SQ-S2, Durham Center area, Durham, Conn.

18. Map showing water levels in bedrock wells in the northern part of the Durham Center area, Durham, Conn., on January 15, 1990.

19. Map showing locations of U.S. Geological Survey partial-record streamflow-gaging stations in the Allyn Brook drainage basin, Durham, Conn.

20. Rating curves for U.S. Geological Survey partial-record streamflow-gaging stations in the Allyn Brook drainage basin, Durham, Conn.

21. Map showing locations of surface-water-quality sampling sites in the Durham Center area, Durham, Conn. 


\section{FIGURES--continued}

22. Map showing concentrations of trichloroethene in water samples from bedrock wells in the Durham Center area, Durham, Conn., January 1982-February 1983..........73

23. Map showing maximum concentrations of trichloroethene in water samples from bedrock wells in the Durham Center area, Durham, Conn., January 1993June 1993

24. Graph showing concentrations of selected organic halides (ethenes) in water samples from well D-191 at Frank W. Strong School, Durham, Conn. .....................................75

25. Graph showing concentrations of selected organic halides (ethenes) in water samples from well D-78 at 262 Main Street, Durham, Conn.................................................. 76

26. Graph showing concentrations of trichloroethene in water samples from well D-191 at Frank W. Strong School and unnumbered wells at 168 Main Street and 174 Main Street, Durham, Conn.

27. Graph showing concentrations of trichloroethene in water samples from unnumbered wells at 159 Main Street, 174 Main Street, and 188 Main Street, Durham, Conn.

28. Map showing locations of bedrock wells in the Durham Center area, Durham, Conn., for which long-term water-quality data are shown in figures 24-27.

29. Idealized block diagram representing the physical framework for a conceptual model of contaminant transport and fate at Durham Center, Durham, Conn.

\section{TABLES}

1. Borehole-geophysical logging done by the U.S. Geological Survey at Durham Center Durham, Conn., July 1993

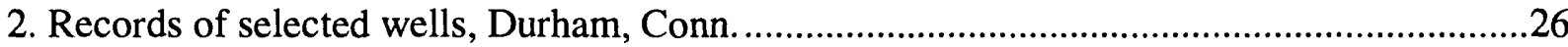

3. Hydraulic properties of till, Durham, Conn..........................................................................35

4. Hydraulic properties of sedimentary bedrock estimated from constant-rate aquifer tests, Durham Center area, Durham, Conn.

5. Discharge measurements and flow-duration estimates for Allyn Brook and selected tributaries in Durham, Conn., in 1993

6. Selected properties of organic compounds detected in ground water and soil samples from the Durham Center area, Durham, Conn

7. Analytical data for surface-water samples collected at Durham, Conn., on August 9, 1982 ..... .68

8. Analysis of water samples from wells tapping the Portland Formation near Durham Center, Durham, Conn. 


\section{CONVERSION FACTORS, ABBREVIATIONS, AND VERTICAL DATUM}

\begin{tabular}{lcl} 
Multiply & By & To obtain \\
\hline inch (in.) & 25.4 & millimeter \\
foot $(\mathrm{ft})$ & 0.3048 & meter \\
mile $(\mathrm{mi})$ & 1.609 & kilometer \\
square foot $\left(\mathrm{ft}^{2}\right)$ & 0.09290 & square meter \\
square mile $\left(\mathrm{mi}^{2}\right)$ & 2.590 & square kilometer \\
gallon $(\mathrm{gal})$ & 3.785 & liter \\
million gallons $(\mathrm{Mgal})$ & 3,785 & cubic meter \\
cubic foot $\left(\mathrm{ft}^{3}\right)$ & 0.02832 & cubic meter \\
foot per day $(\mathrm{ft} / \mathrm{d})$ & 0.3048 & meter per day \\
gallon per minute $(\mathrm{gal} / \mathrm{min})$ & 0.06309 & liter per second \\
gallon per day $(\mathrm{gal} / \mathrm{d})$ & 0.003785 & cubic meter per day \\
million gallons per day $(\mathrm{Mgal} / \mathrm{d})$ & 0.04381 & cubic meter per second \\
foot squared per day $\left(\mathrm{ft}^{2} / \mathrm{d}\right)$ & 0.09290 & meter squared per day \\
gallon per minute per foot $(\mathrm{gal} / \mathrm{min} / \mathrm{ft})$ & 0.2070 & liter per second per meter \\
\hline
\end{tabular}

Abbreviated water-quality units used in this report:

$\begin{array}{ll}\mathrm{mg} / \mathrm{L} & \text { milligrams per liter } \\ \mu \mathrm{g} / \mathrm{L} & \text { micrograms per liter } \\ \mu \mathrm{S} / \mathrm{cm} & \text { microsiemens per centimeter at } 25 \text { degrees Celsius }\end{array}$

For temperature conversions between degrees Celsius $\left({ }^{\circ} \mathrm{C}\right)$ and degrees Fahrenheit $\left({ }^{\circ} \mathrm{F}\right)$, the following formulas may be used:

$$
\begin{aligned}
& { }^{\circ} \mathrm{C}=5 / 9 \times\left({ }^{\circ} \mathrm{F}-32\right) \\
& { }^{\circ} \mathrm{F}=\left(1.8 \times{ }^{\circ} \mathrm{C}\right)+32
\end{aligned}
$$

Sea level: In this report "sea level" refers to the National Geodetic Vertical Datum of 1929 (NGVD of 1929)- a geodetic datum derived from a general adjustment of the first-order level nets of both the United States and Canada, formerly called Sea Level Datum of 1929. 


\title{
GEOHYDROLOGY AND WATER QUALITY OF THE DURHAM CENTER AREA, DURHAM, CONNECTICUT
}

\author{
by Robert L. Melvin, Janet Radway Stone, Patrick A. Craft, \\ John W. Lane, Jr., and Bruce S. Davies, 3d
}

\section{ABSTRACT}

Contaminated ground water is widespread and persistent beneath the Durham Center area in the town of Durham, Conn. Most of the contaminants are organic halides, usually trichloroethene, 1,1,1-trichloroethane, and tetrachloroethene. Less extensive chemical contamination of surface water, soil, and glacial sediments also has been detected. Two manufacturing companies, located at the northern and southern ends of this largely residential area, are believed to be the principal sources of the organic compounds detected in ground water.

The contamination of water in the bedrock, the primary source of drinking water throughout the area, is the major environmental concern. Maximum concentrations of trichloroethene in three bedrock wells range from 4,500 to about 5,500 $\mu \mathrm{g} / \mathrm{L}$ (micrograms per liter). Concentrations of trichloroethene greater than $5 \mu \mathrm{g} / \mathrm{L}$, the maximum contaminant level established for drinking water by the U.S Environmental Protection Agency, have regularly been detected in water samples from many other bedrock wells for at least 9 years.

The geohydrology of the area is highly complex. Compact lodgment till that is up to 30 feet thick and probably fractured, overlies the bedrock. The bedrock is lithologically heterogeneous, and consists mostly of red fluvial sandstone, siltstone, and conglomerate; it is locally interbedded with black lacustrine shales and gray sandstones. Lithology and stratigraphy interpreted from borehole-geophysical logs at Durham Center are consistent with the Portland Formation subfacies described in earlier geologic studies. Beds strike nearly north-south and dip gently eastward. At least one high-angle normal fault transects the bedrock; it strikes northeast and dips northwest. Acoustic televiewer logs, measurements at outcrops, and azimuthal, squarearray, resistivity data indicate a dominance of northeast-striking fractures that dip steeply northwest and southeast. Less prevalent strike directions are north to east-northeast.

The till and sedimentary bedrock are dual-porosity, dual-permeability media. The hydraulic conductivity of the bulk mass of till is believed to be on the order of tenths of a foot per day to about 2.5 feet per day, with a total porosity of about 25 percent and an estimated average fracture porosity of less than 1 percent. The reported transmissivities of the bedrock range from less than 1 to about 1,700 feet squared per day and storativity is generally about $10^{-4}$, but the accuracy of these values is uncertain. The intergranular porosity of the sandstone units is estimated to average 5 percent, and estimates of fracture porosity from square-array, resistivity soundings at two sites were 1.1 and 2.7 percent.

The bedrock has characteristics of both a single aquifer and a multi-unit, artesian or leaky aquifer system. A local ground-waterflow system that includes the upper part of the bedrock is unconfined. A large-scale flow system in deeper parts of the bedrock has transported organic compounds across topographic drainage divides. Borehole-geophysical logs and head measurements indicate that the natural ground-water-flow system in the bedrock has been altered by drilled wells that connect fractures and by withdrawals from wells. A conceptual model of the movement and fate of organic contaminants suggests that 
(1) nonaqueous phase organic halides are retained near their source; (2) flow is primarily through fractures in the till and through fractures and bedding-plane openings in the sedimentary rocks; (3) retardation of contaminants occurs primarily by diffusion from fractures into the aquifer matrix; and (4) transport directions of dissolved organic halides are controlled by a combination of natural hydraulic gradients, hydraulic gradients produced by the cyclical pumping of wells, and by the strike directions of bedrock faults, fractures, and bedding planes.

\section{INTRODUCTION}

In 1992, the U.S. Geological Survey (USGS), in cooperation with the U.S. Environmental Protection Agency (USEPA), began geohydrologic investigations of selected sites of ground-water contamination in New England. These sites are on the National Priorities List (NPL) (U.S. Environmental Protection Agency, 1988, 1989), which was developed under the authority of the Comprehensive Environmental Response, Compensation, and Liability Act of 1980, as amended by the Superfund Amendments and Reauthorization Act of 1986 (commonly known as Superfund). The objective of these investigations was to develop a preliminary characterization and understanding of the regional and local geohydrology of the sites using existing data, supplemented by a limited amount of new data primarily collected by methods other than drilling or excavation. The geohydrologic characterization can be used to aid the development of Superfund Remedial Investigation/Feasibility Studies that will be required at these sites.

Durham Center, the second area in New England selected for study under the USGSUSEPA program, is a long-established residential, industrial, and commercial area that borders Main Street (Connecticut Route 17) in the town of Durham, Conn. (fig. 1). Extensive degradation of ground-water quality by organic chemicals has taken place in this area and less extensive contamination of soil and underlying glacial deposits has been detected at the sites of two manufacturing companies (Leggette, Brashears, and Graham, Inc., 1982; Roux Associates Inc., 1983, 1988, 1990a).

In 1982, DEP issued pollution abatement and water-supply orders to Merriam Manufacturing Co. ${ }^{1}$ and Durham Manufacturing Co. because DEP considered these companies to be the likely source of the ground-water contamination in the Durham Center area (The Hartford Courant, 1983; The New York Times, 1984). USEPA evaluated the Merriam Manufacturing Co. facility in 1985 (R.J. Ross, NUS Corp., written commun., 1985) under authority of the Superfund program. In 1988, USEPA concluded that the site, whose name had been changed from Merriam Manufacturing Co. to Durham Meadows ${ }^{2}$ was appropriate for placement on the NPL (U.S. Environmental Protection Agency, 1988). The Durham Meadows site was added to the NPL on October 4, 1989 (U.S. Environmental Protection Agency, 1989), although there was some uncertainty as to the boundaries of the site and whether sources of contamination other than Merriam Manufacturing Co. facility should be part of the site. Subsequently, both Merriam Manufacturing Co. and Durham Manufacturing Co. were included as possible sources of contamination (U.S. Environmental Protection Agency, 1994) and notified that they were potential responsible parties for investigation and remedial activities at the Durham Meadows Superfund site (M.S. Hohman, U.S. Environmental Protection Agency, written commun., 1993).

\footnotetext{
${ }^{1}$ The use of trade, product, industry, or firm names in this report is for identification or location purposes only, and does not constitute endorsement of products by the U.S. Geological Survey, nor impute responsibility for any present or potential effects on the natural resources.

${ }^{2}$ Durham Meadows is the geographic name of a wetland located west of Durham Center.
} 


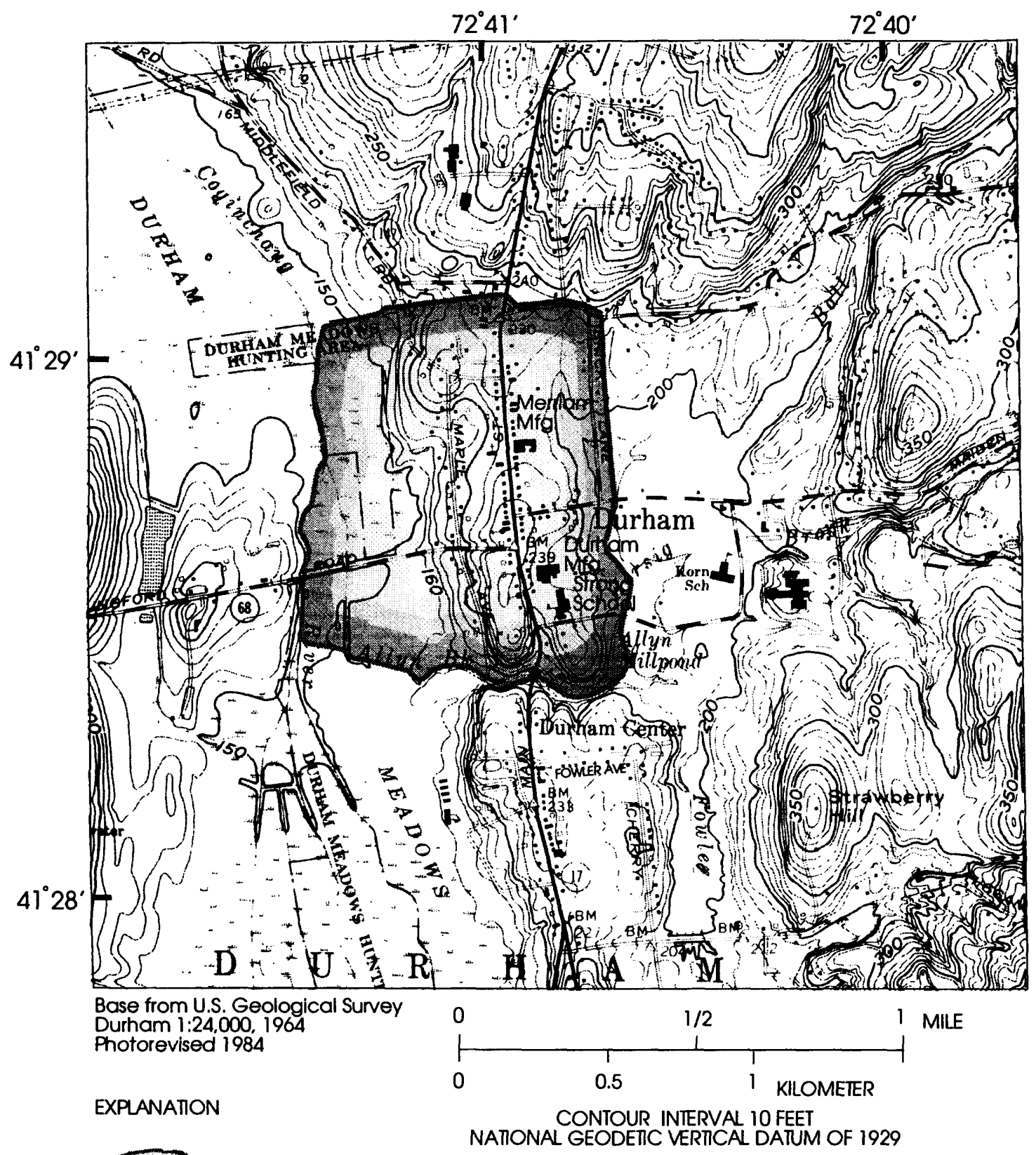

Study area

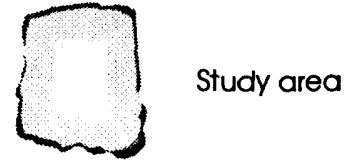

A. WESTERN HIGHLANDS

B. CONNECTICUT VALLEY LOWLAND

C. EASTERN HIGHLANDS

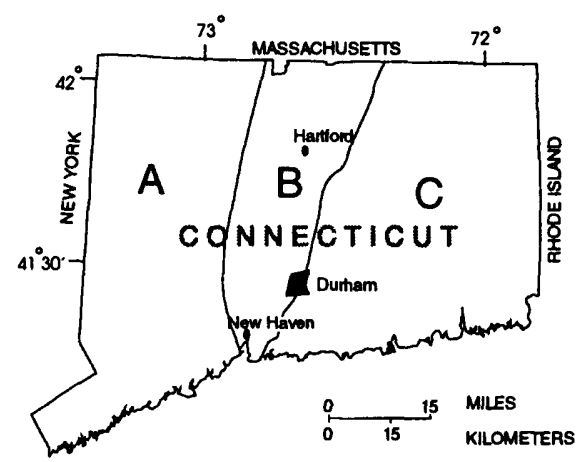

Figure 1. Location of the Durham Center area, Durham, Conn. 


\section{Purpose and Scope}

This report describes the geohydrology and water quality of the Durham Center area. It summarizes the findings of several published and unpublished reports and maps that were reviewed as part of this study, as well as information obtained from files of the USEPA, USGS, the Connecticut Department of Environmental Protection (DEP), the Connecticut Department of Health Services (DOHS), the town of Durham, and Regional School District 13. The report also contains the results of field work, which included an extensive inventory of wells; detailed geologic mapping, with emphasis on interpreting the lithology and structural features of the sedimentary bedrock; surface-geophysical surveys; borehole-geophysical surveys; and measurements of stream stage, streamflow, and water-level fluctuations in wells. The surface-geophysical surveys included 2 square-array, direct-current (dc) resistivity traverses; 2 square-array dc-resistivity soundings; 5 very low-frequency electromagnetic (VLF-EM) traverses; and 7 groundpenetrating radar (GPR) profile lines. The borehole-geophysical surveys, in 13 drilled bedrock wells, included several combinations of caliper, temperature, gamma, fluid-resistivity, focused-resistivity, self-potential, spontaneous-potential, acoustic-televiewer, and acoustic-velocity logs. Heat-pulse flowmeter measurements were made at selected depths in 8 wells and television camera logs were recorded on video tape for 10 wells. The report also describes a conceptual model of the movement and fate of organic contaminants in ground water at Durham Center that should provide guidance for any subsequent remedial investigation and feasibility study.

\section{Previous Studies}

The Durham Center area was included in a regional hydrologic study of the lower Connecticut River basin (Weiss and others, 1982) and in a hydrogeologic study of the town of Durham (Klimenok, 1989). The bedrock and surficial geology of the area are described in maps and reports by Simpson (1968a, 1968b), Rodgers (1985), LeTourneau (1985), LeTourneau and McDonald (1985), and Stone and others (1992). In March 1970, several compounds, including tetrachloroethane and chloroform, were found in water samples collected by the DOHS from the well supplying the Durham High School (now the Frank W. Strong Middle School) and from Ball Brook (fig. 1) (G.G. Bonadies, Connecticut Dept. of Health Services, written commun., 1970).

No subsequent water-quality investigations are known to have taken place until the DEP initiated a survey of ground-water quality in 1982. During a 14-month period (January 1982 to February 1983), 78 separate watersupply sources were sampled and analyzed by the State and 14 of these sources were resampled and reanalyzed. Additional analyses by private laboratories of samples from six other water-supply sources were collected during this period. Analyses of samples for the January 1982 to February 1983 period represent the most comprehensive data on ground-water quality in the Durham Center area. The organic halides trichloroethene (TCE), 1,1,1-trichloroethane (1,1,1-TCA), and tetrachloroethene (PCE) were the most commonly detected compounds, but several other hydrocarbons were detected less frequently. Most water samples were collected from drilled domestic wells that tap fractured sedimentary bedrock; the rest were from dug wells that tap glacial till or from springs.

Several studies have been done to comply with DEP Pollution Abatement Orders issued in 1982. Leggette, Brashears, and Graham, Inc. (1982) studied ground-water contamination in the southern part of Durham Center. This study included an aquifer test to determine hydraulic properties of the bedrock and an analysis of flow and water quality in the upper part of the saturated zone above the bedrock. This firm also completed a soil-gas 
survey in June 1992 on properties located southwest of the Durham Manufacturing Co. (Robert LaMonica, Leggette, Brashears, and Graham, Inc., written commun., 1992).

P.H. Roux Associates Inc. made a series of studies in the northern and central parts of the Durham Center area. The first study (Roux Associates Inc., 1983) assessed the contamination of soil, glacial sediments, and ground water at Merriam Manufacturing Co., summarized the DEP water-quality data, and made recommendations for further study. An additional study, made on behalf of Merriam Manufacturing Co. in 1988 (Roux Associates Inc., 1988), included more extensive investigation of the contamination of soil and glacial sediments, installation of bedrock monitoring wells, and collection and analyses of groundwater samples. An analysis of water-quality data led to conclusions about the general directions of ground-water flow, relations between TCE concentrations in water from bedrock wells and proximity to Merriam Manufacturing Co., and seasonal trends in TCE concentrations in ground water.

A second phase of the site investigation at Merriam Manufacturing Co., starting in 1989 and ending in March 1990, is described in three reports (Roux Associates Inc., 1990a, 1990b, and 1990c). This investigation included additional study of the contamination of soil and glacial sediments on the Merriam property, assessment of ground-water flow eastward to adjacent wetlands, fracture-trace analysis, installation of additional bedrock monitoring wells, and hydraulic tests of selected bedrock monitoring wells (includes testing intervals isolated by a packer). The study identified principal areas of contaminated soils and glacial sediments, presented evidence of eastward flow of ground water, established a relation between orientation of fracture traces and higher concentrations of TCE in domestic wells, and found that TCA rather than TCE had become the dominant organic contaminant in some on-site bedrock monitoring wells.
Roux Associates Inc. made a soil-gas survey at Merriam Manufacturing Co. in August 1990 (D.A. Costolnick, Roux Associates Inc., written commun., 1990) and collected and analyzed samples of soil and glacial sediments from two new borings in November 1990. Additional piezometers were installed east and northeast of Merriam Manufacturing Co. in November 1990 (Roux Associates Inc., 1990a), and in 1991, a water-quality screening program was proposed (Roux Associates Inc., 1991a). This latter report (Roux Associates Inc., 1991a) also summarized the water-quality data collected during August 1988 - October 1990 , evaluated water-quality trends during this period, and estimated where the perimeter of the plume of contaminated ground water associated with Merriam Manufacturing Co. was located.

The most recent study for Merriam Manufacturing Co. included a soil-gas survey at Merriam Manufacturing Co. and sampling and analysis of storm-water runoff from the roof of Merriam Manufacturing Co. (Haley and Aldrich, 1992). This study, made in July and August 1992, found TCA, TCE, and PCE at most soil-gas sampling sites and low concentrations of TCA in runoff from the roof of Merriam Manufacturing Co.

In August, 1989, Roy F. Weston Inc., under contract to USEPA, collected shallow soil samples at Merriam Manufacturing Co. and a water sample from the company's production well. Analytical results are contained in a report prepared for USEPA (Roy F. Weston Inc., 1989). Metcalf and Eddy Inc., also under contract to the USEPA, collected samples of surface water, soil, and stream-bottom sediment in the Allyn Brook watershed in July 1993. These data, together with previous analyses of water, soil, and glacial sediment, are included in a data compilation prepared for USEPA (Metcalf and Eddy Inc., 1994). 


\section{PHYSICAL AND HYDROLOGIC SETTING}

\section{Physiography and Geology}

Durham Center is near the eastern border of a broad north-south-trending lowland in central Connecticut and Massachusetts; this lowland is variously known as the Connecticut Valley Lowland, the Central Lowland, or the Hartford Basin (fig. 1). The lowland is divided into eastern and western sections by a band of locally offset, narrow, linear ridges called traprock ridges. Several miles to the west and south of Durham Center, traprock ridges rise 600 to $800 \mathrm{ft}$ above sea level. About $2 \mathrm{mi}$ to the east of Durham Center, the Eastern Highlands of Connecticut also reach altitudes greater than $700 \mathrm{ft}$. Durham Center, which is located on the north-central part of the Durham 7.5-minute topographic quadrangle map, lies on a low hill that rises to about $240 \mathrm{ft}$ above sea level within a broad basin defined by the surrounding higher hills (fig. 2). This basin slopes northward and is drained by the Coginchaug River, which flows through a lowlying, fairly flat area, Durham Meadows, just west of Durham Center. To the east of Durham Center, a less extensive flat-lying area is drained by Ball Brook and Hersig Brook; these join north-flowing Fowler Brook and become Allyn Brook, which flows westward through a rock gorge to Durham Meadows and the Coginchaug River.

The physiography of the area is a result of geologic processes acting over an extended period. Differential effects of erosional processes on the lithology and structure of the underlying bedrock, including those of relatively recent continental glaciation, produced the existing configuration of the bedrock surface. Deposition of glacial sediments during the retreat of the last (late Wisconsinan) ice sheet and minor postglacial stream erosion modified the bedrock surface, resulting in the present physiography.

The geology of the area is shown in figure 3. Highlands to the east of Durham Center are underlain by erosion-resistant, crystalline (metamorphic and igneous) rocks of Paleozoic age including schist, gneiss, and intrusive pegmatite (figs. $3 \mathrm{a}$ and $3 \mathrm{c}$ ). The traprock ridges to the west and south of Durham Center are formed of highly resistant, igneous rocks consisting of tholeiitic basalt of Early Jurassic age. These rocks are eastward-dipping massive lava sheets and are extensively fractured by joints that formed when the lava cooled.

The area beneath Durham Center, as well as the rest of the Connecticut Valley Lowland (exclusive of the traprock ridges), is underlain by layered sedimentary rocks that are more readily eroded and weathered than the metamorphic or igneous rocks. These rocks include sandstone, siltstone, shale, and conglomerate that accumulated in an asymmetric, blockfaulted, rift basin during Late Triassic to Early Jurassic time. The basin was created by vertical downward movement along a west-dipping normal fault, which is composed of a series of north- and northeast-striking segments. This fault (the Eastern Border Fault) marks the eastern extent of sedimentary rocks in contact with crystalline rocks of the Eastern Highlands. Sediment was deposited by rivers that flowed from the east and west into the rift basin; sedimentation was concurrent with rifting and sinking of the basin, so that movement on the Eastern Border Fault strongly affected depositional processes in the basin (Eaton and Rosenfeld, 1960; LeTourneau, 1985). Exposed strata typically dip $10^{\circ}$ to $20^{\circ}$ east toward the border fault. In the central part of the basin, many northeast-striking, west-dipping, normal faults cut and offset the traprock ridges and sedimentary rocks. 


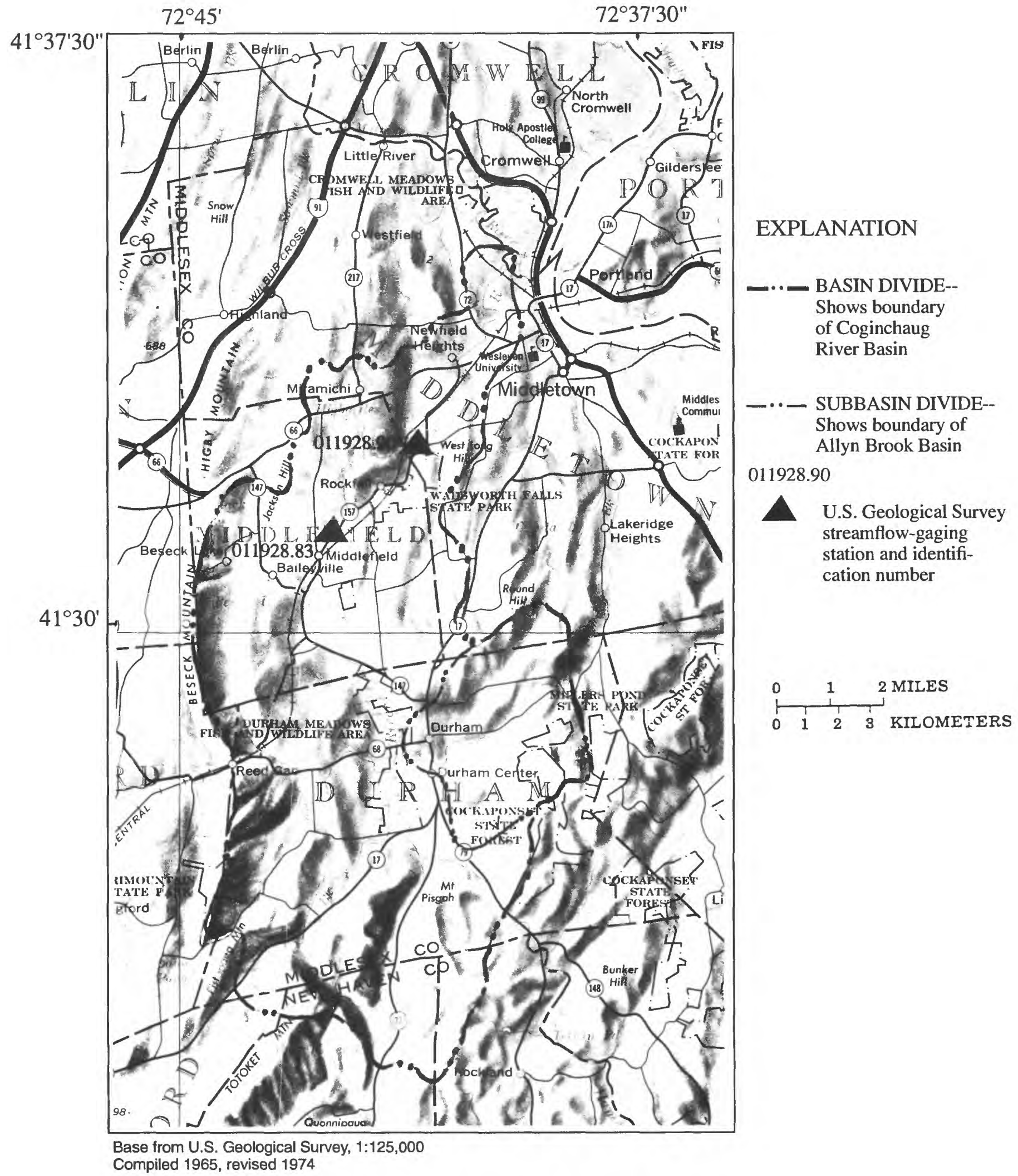

Figure 2. The Coginchaug River basin, Conn. 


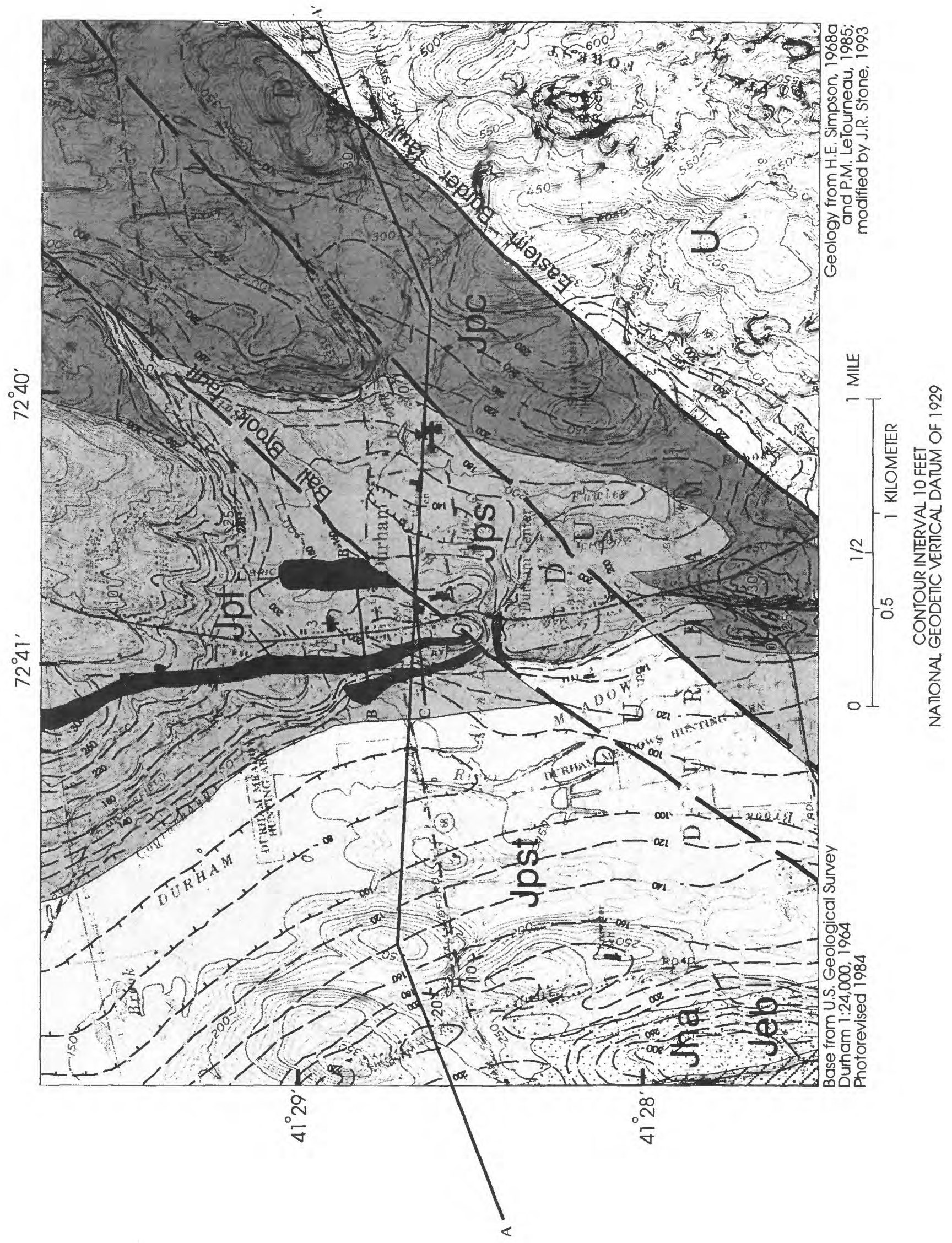




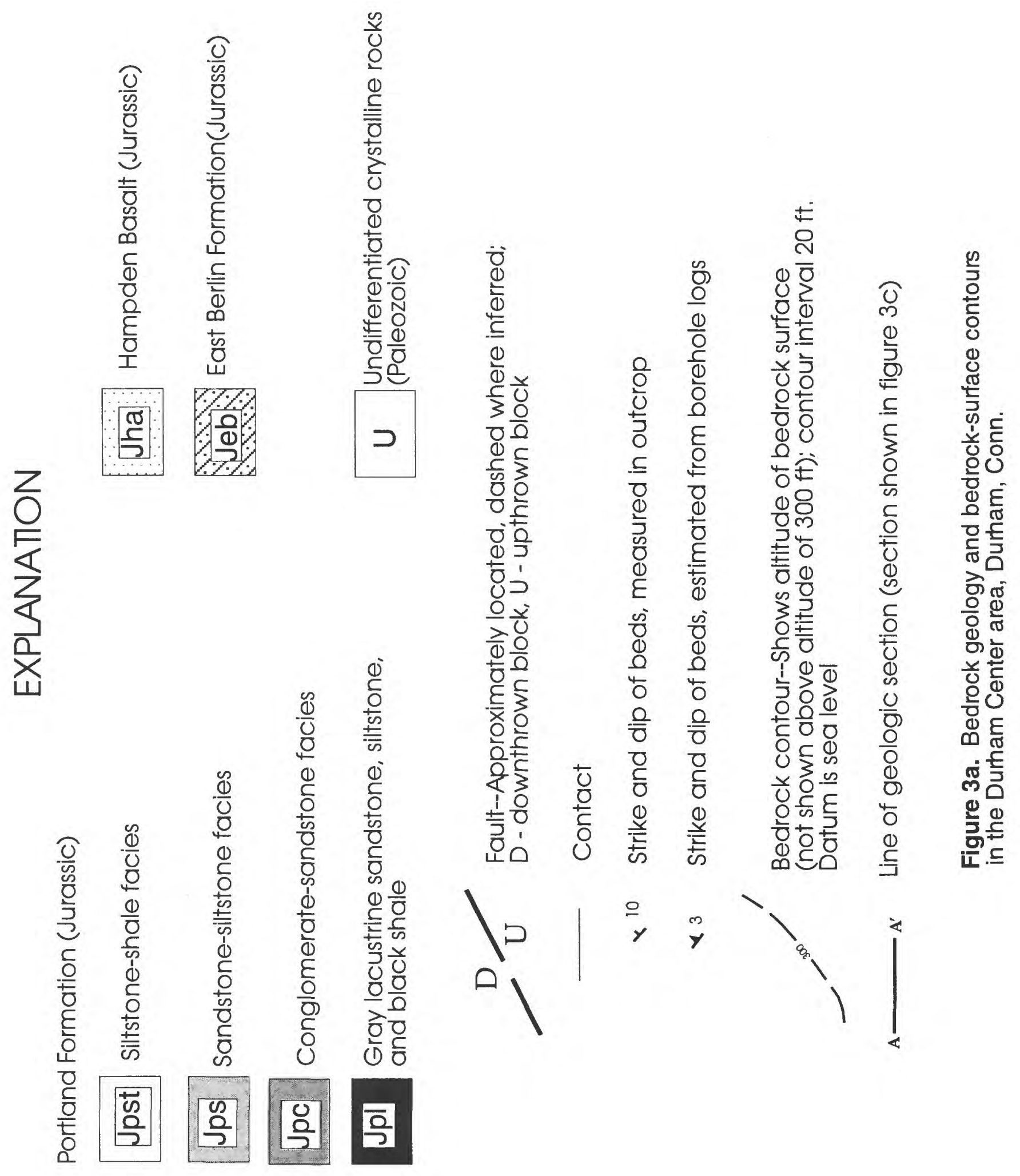




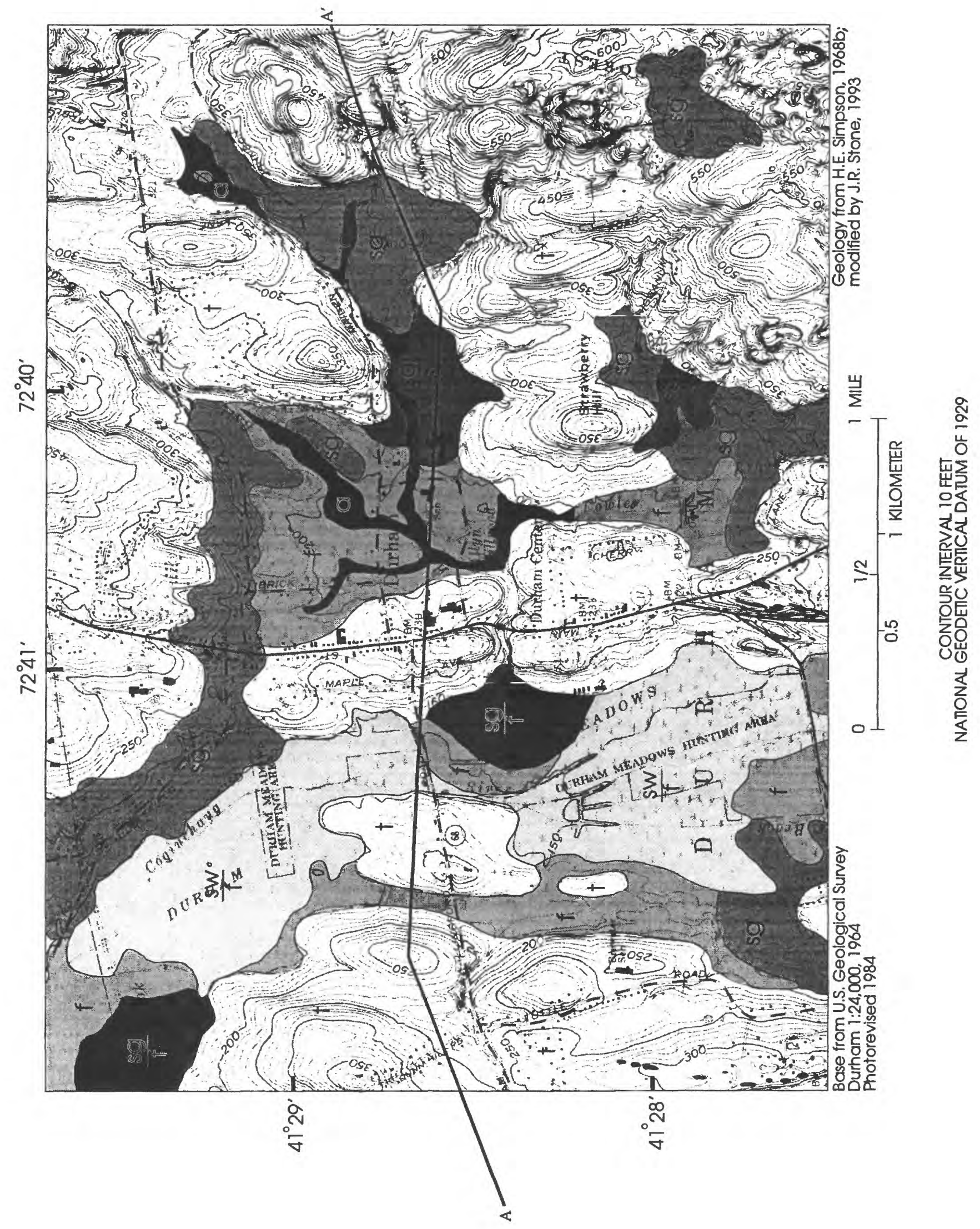




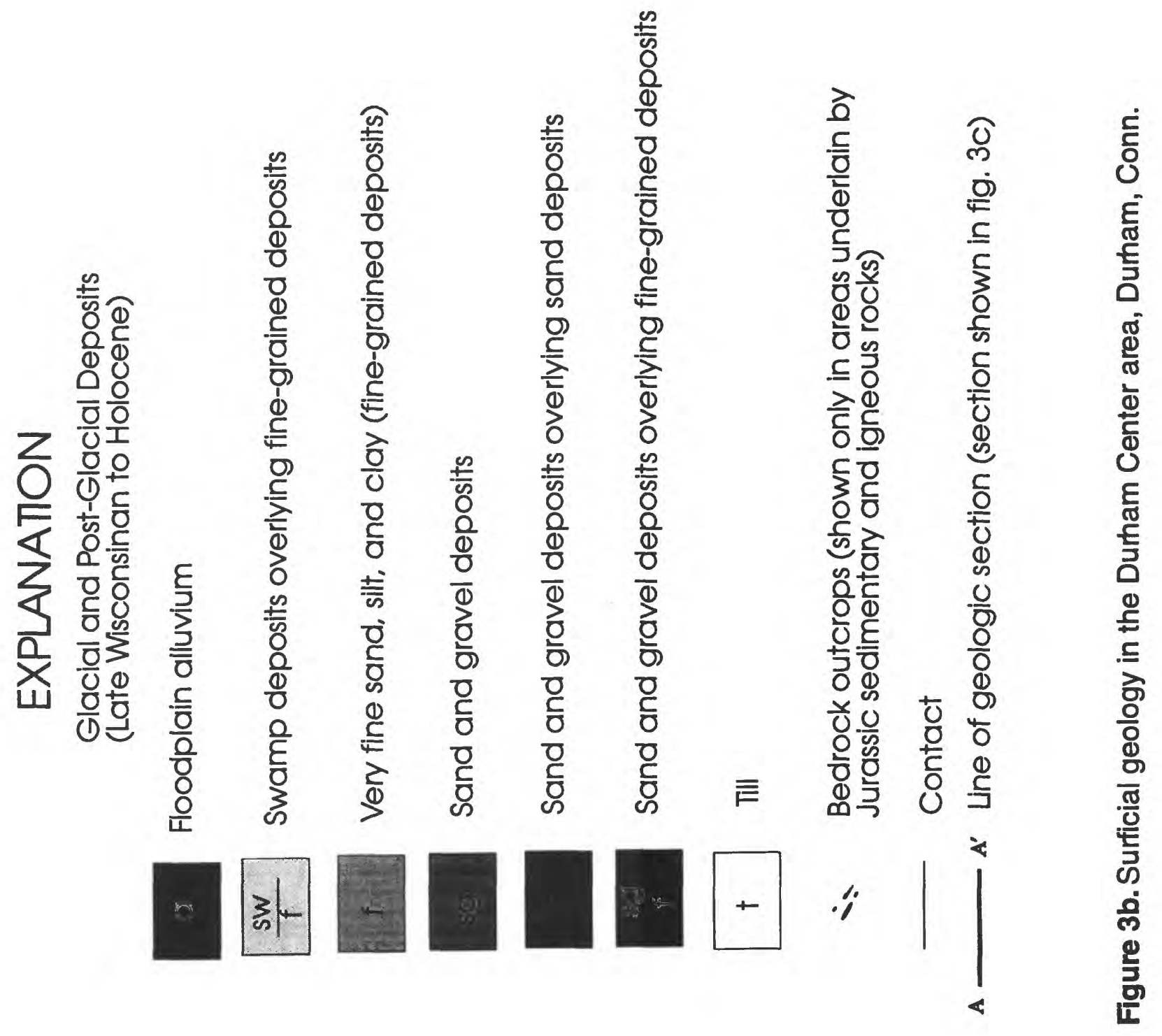




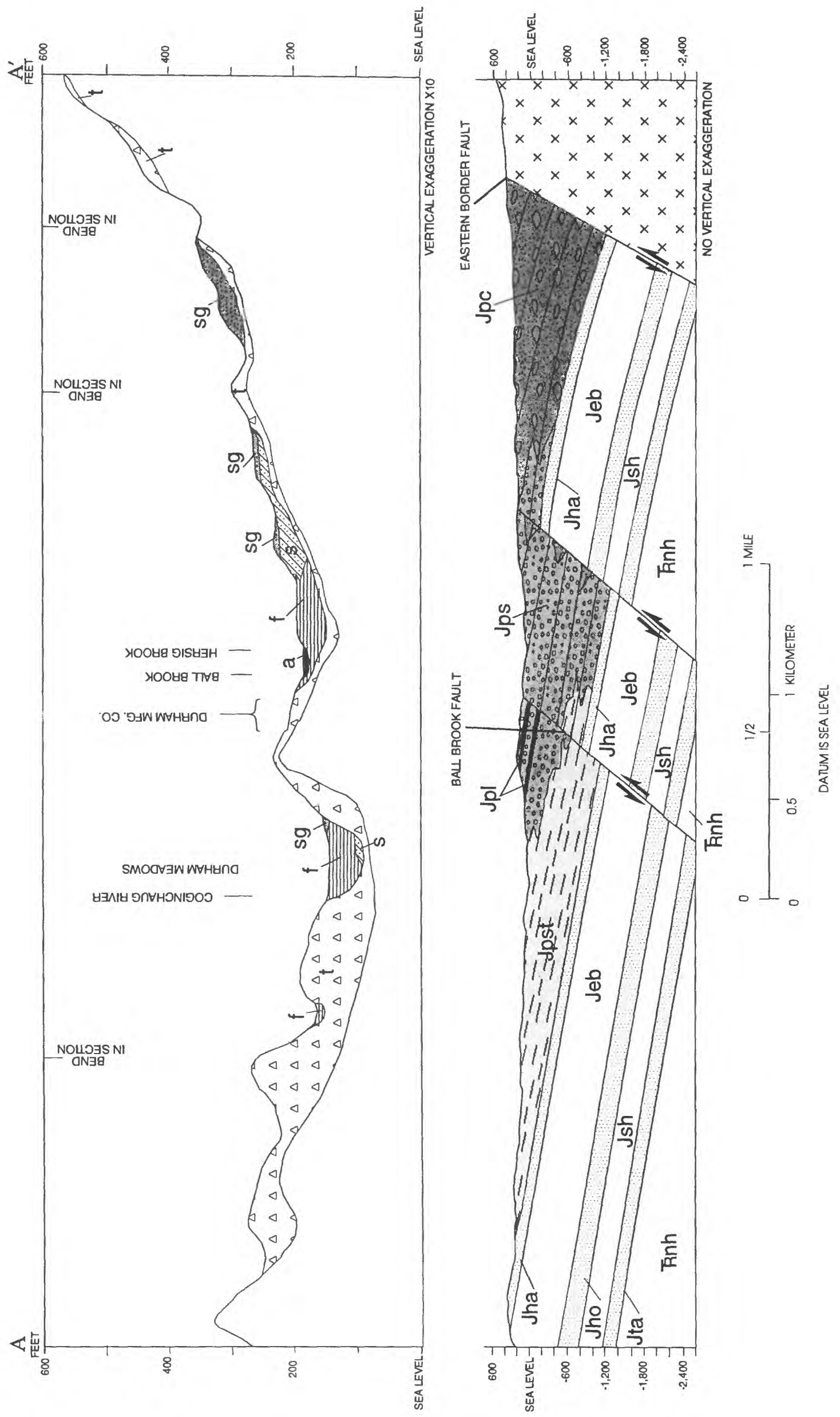




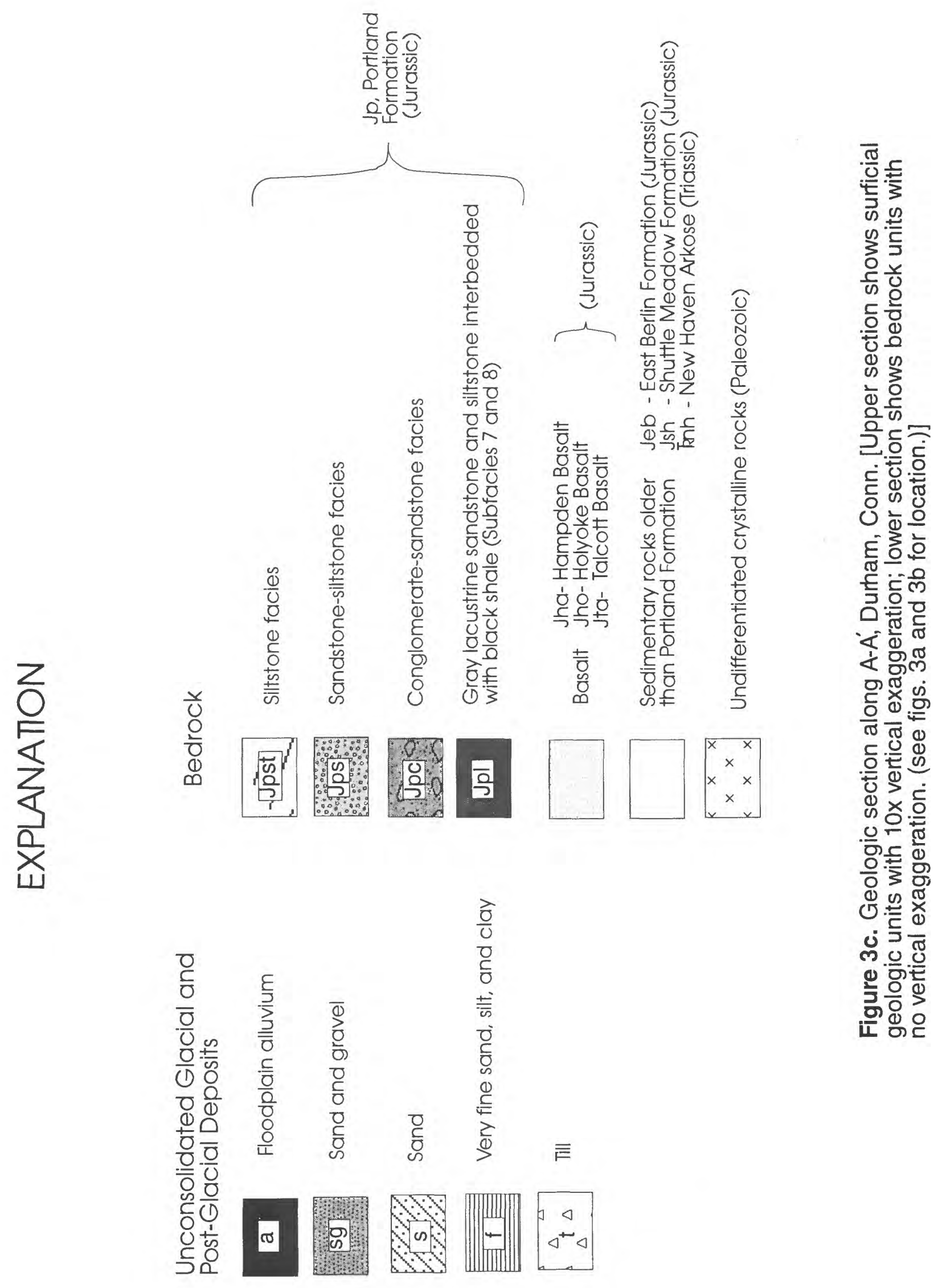


The sedimentary rocks are predominantly red to reddish brown due to the presence of authigenic hematite (iron oxide) pigment on sand-grain surfaces. The sediments are fluvial and include alluvial-fan, braidedstream, and mudflat deposits. Locally, gray lacustrine sandstones and black shales are interbedded with the red brown layers. Following deposition, the sediments became indurated by precipitation of albite overgrowths and carbonate cements, forming the now wellconsolidated rocks with relatively low porosities.

Thin patches of saprolite or weathered bedrock are present only locally in this region because most weathered bedrock was removed and redeposited as drift by multiple episodes of continental glaciation. Glacial sediments directly overlie fresh, unweathered bedrock in this area (figs. $3 b$ and $3 c$ ). Till, deposited during at least two glaciations, overlies bedrock in most of the Durham area. Several smooth, north- and north-northeast (NNE)- trending hills in Durham (for example, Strawberry Hill) are drumlins composed entirely, or almost entirely, of till. The bulk of sediment in these drumlins is believed to be very compact, relatively fine-grained, fractured, drumlin (lower) till deposited during the earlier (Illinoian) glaciation (Stone in Weddle and others, 1989; Melvin and others, 1992a, 1992b).

During the retreat of the last (late Wisconsinan) ice sheet, thick accumulations of sediment (stratified drift) were deposited in bedrock valleys by glacial meltwater (fig. 3b). Most of the stratified drift in the Durham Center area was deposited as deltas and lake-bottom sediment in glacial Lake Coginchaug, a temporary, ice-dammed lake that occupied all of the Coginchaug River valley as well as tributary valleys. The water level of this glacial lake in the Durham Center area was approximately $300 \mathrm{ft}$ above present sea level; the lake was impounded by the ice margin to the north and spilled out across the drainage divide to the south through an outlet at an altitude of 275 ft. Deltas composed of sand and gravel were built into the lake in places along its margins; fine-grained sediment settled out in quiet water in the central parts of the lake. When the icemargin retreated farther north into Middletown, Conn., lower outlets became available, draining the glacial lake and allowing the Coginchaug River to flow across the lake bed (Durham Meadows). Tributary streams such as Allyn Brook locally built thin, coarse-grained alluvial fans on top of the glacial lake sediments.

\section{Hydrology}

The regional hydrology of the Durham Center area has been described by Weiss and others (1982) and general patterns of groundwater flow are discussed by Klimenok (1989). Surface water flows directly into the Coginchaug River or its tributaries in the Allyn Brook subbasin. (See fig. 2.) Hydrologic data for the area are contained in both of these reports, as well as in Bingham and others (1975), Roux and Associates Inc. (1988, 1990a, 1990b), and the annual series of USGS data reports titled "Water Resources Data for Connecticut."

Durham is in the State's Southeast Hills climate regime (Brumbach, 1965). The National Weather Service (NWS) has a longterm station located at Middletown, Conn., about $4.5 \mathrm{mi}$ northwest of Durham Center. Data collected at this station for the 30-year reference period 1951-80 (National Oceanic and Atmospheric Administration, 1992) show a normal annual temperature of about $50^{\circ} \mathrm{F}$ and a normal annual precipitation of about 50 in. The coldest month is January (normal temperature of $27.4^{\circ} \mathrm{F}$ ) and the warmest is July (normal temperature of $72.5^{\circ} \mathrm{F}$ ). Average monthly precipitation is, in general, evenly distributed throughout the year (Weiss and others, 1982) but the precipitation in any given month varies considerably over a long-term period. Average 
annual precipitation calculated from data collected at the NWS station at Middletown, Conn., for the 30-yr period January 1962 to December 1991 is shown in figure 4. During this period, the annual precipitation ranged from 36.5 in. (1965) to 69.2 in. (1983) and averaged 49.9 in. Runoff from the Coginchaug River basin has been measured over most of the same 30 -yr period by two continuousrecord USGS gages shown in figure 2 (station 011928.90 from $1962-80$ and station 011928.83 from 1982-91). The runoff computed by calendar year ranged from 11.4 in. (1965) to 45.2 in. (1983) and averaged about $26 \mathrm{in.}$ The average annual evapotranspiration during this period is estimated to be equal to the difference between the average annual precipitation and the average annual runoff--about 24 in.

The annual evaporation is relatively constant for a given location (Weiss and others, 1982). Therefore, for the 30 -yr period $1962-$ 91 , the average annual remainder of approximately 26 in. of water (1) runs off the land surface to nearby streams, swamps, and lakes (direct runoff) or (2) percolates to the saturated zone and is withdrawn by wells or flows to natural discharge points such as streams, swamps, lakes, and springs.

Three geohydrologic units are present in this area: stratified drift, till, and sedimentary bedrock. Stratified drift and till are unconsolidated glacial deposits, whereas sedimentary bedrock is consolidated rock that ranges in texture from shale to conglomerate. The areal distribution of these units is shown in figures 3a and $3 \mathrm{~b}$, and subsurface spatial relations between the units are shown in figure 3c. Coarse-grained stratified-drift deposits (coarser than very fine sand) that are thick and extensive form the major aquifers in Connecticut. Most of the stratified drift near Durham Center, however, is composed of fine-grained glaciolacustrine sand, silt, and clay (fig. $3 b$ ). These deposits have low permeability and are poor (low-yield) aquifers. Stratified drift, under natural conditions, receives recharge from precipitation that percolates down to the water table. The long-term average annual recharge to stratified drift from precipitation has been estimated by a regionalization tech-

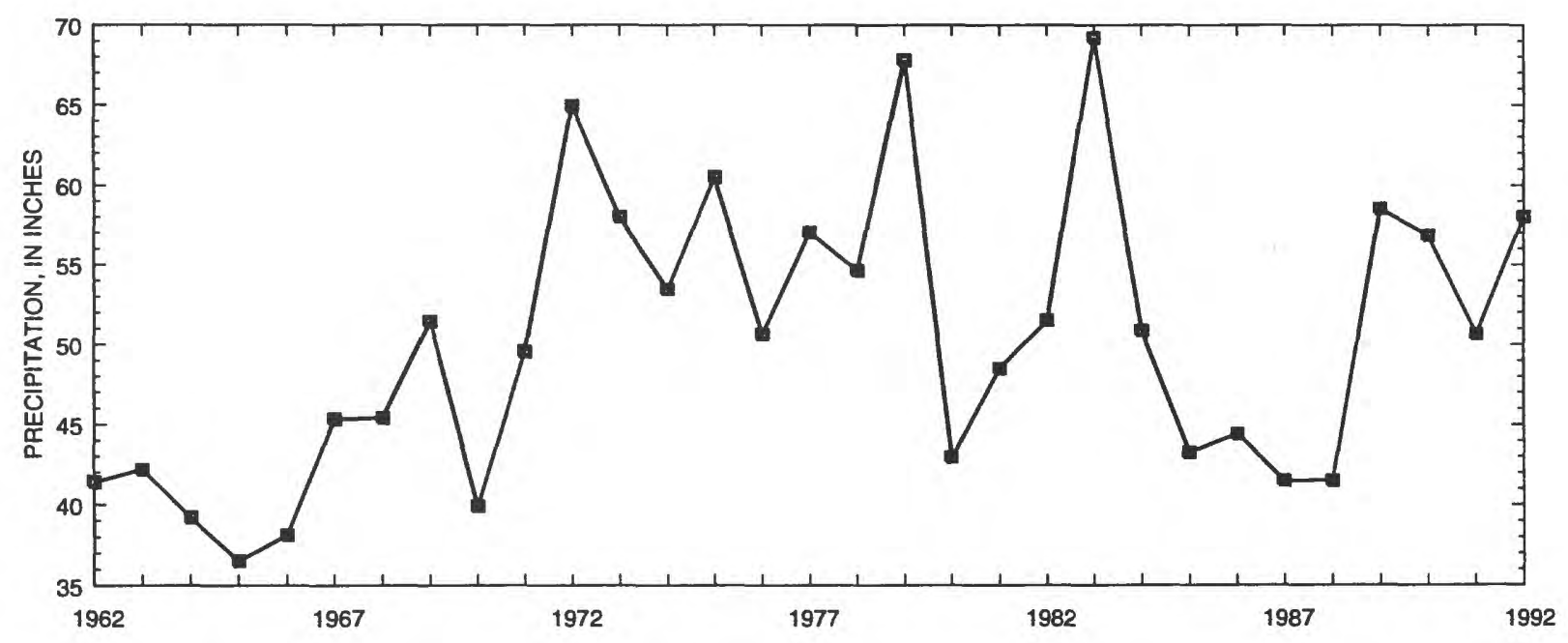

Figure 4. Average annual precipitation at Middletown, Conn., January 1962December 1991. 
nique (Cervione and others, 1972; Mazzaferro and others, 1979) to be equal to about 90 percent of the average annual runoff, or 23.4 in for the Durham area.

Till usually has low permeability and may be unsaturated or have only a thin saturated zone for much of the time. Although till is rarely used as a source of water supply, it is still an important geohydrologic unit, serving as a connection between the land surface and underlying bedrock aquifers in most of this area, as shown in figure $3 \mathrm{c}$.

Bedrock is the principal aquifer for onsite domestic water supply as well as for small on-site commercial, industrial, and institutional supplies. Water in the bedrock aquifers is primarily transmitted through networks of interconnected open fractures (joints and faults) and openings formed along bedding planes in sedimentary rocks. Yields of wells that tap sedimentary rocks and the other types of bedrock aquifers in this part of Connecticut, reported by Weiss and others (1982), are shown in figure 5 . The yield shown in figure 5 may underestimate the potential of the bedrock aquifers because most of the wells were drilled for domestic use and large yields were not required.

Separate estimates of till and bedrock recharge rates have not been made. However, an aggregate rate for both units has been estimated using the regionalization technique described by Cervione and others (1972) and Mazzaferro and others (1979). The combined long-term average annual recharge to till and bedrock is estimated to be 30 percent of longterm average annual runoff, or about $8 \mathrm{in}$., for the Durham area. Recharge occurs over most of the landscape except in low valleys, which are predominantly discharge areas.

Surface-water and ground-water flow in most of Connecticut are localized within basins drained by perennial streams and, under natural conditions, each basin is considered to be a closed system (Melvin and others, 1985, p. 161). That means the water entering a basin is limited to the precipitation that falls within the basin divides, surface-water drainage divides are coincident with the lateral boundaries of ground-water flow systems, and water leaves the basin only by evapotranspiration or as streamflow. An idealized pattern of surfacewater and shallow (upper part of the saturated zone) ground-water circulation in the Durham Center area under the typical natural flow regimen is shown in figure 6. Klimenok (1989) assumed that the ground water is unconfined in Durham and produced a water-level contour map using water levels in drilled wells and altitudes of stream reaches and ponds (Klimenok, 1989, fig. 13). The contours on this map are a subdued reflection of the surface topography and show a general pattern of horizontal ground-water movement toward the Coginchaug River valley from both the east and west.

Weiss and others (1982, p. 26) proposed that large-scale ground-water flow systems may be present in the sedimentary rocks of the Connecticut Valley Lowland. In these largeflow systems, surface-water drainage divides and boundaries of ground-water flow systems may differ and some ground water flows across the topographic divides that separate drainage basins. Certain water-quality data and historic data on hydraulic heads in the bedrock, subsequently described in this report, indicate that this regional ground-water flow is present in at least part of the Durham Center area and is controlled by bedrock structural features and is affected by withdrawals from wells.

\section{Water Use}

The source of the water used in the study area is ground water, almost all of which is withdrawn from the sedimentary bedrock. Part of the area was served by a public water company, until 1979, when the company's supply source, a spring located on the Durham- 


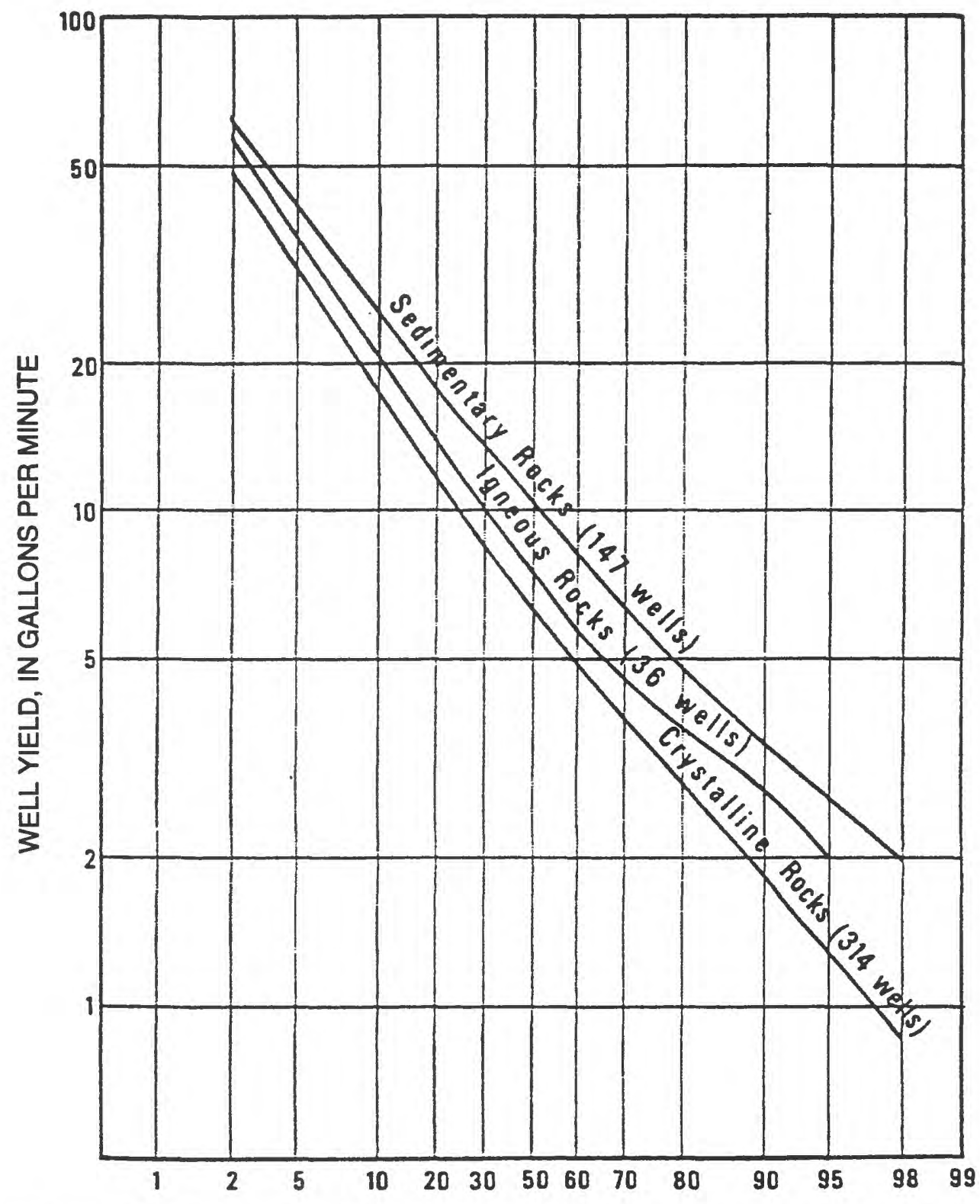

PERCENTAGE OF WELLS WITH YIELDS EQUAL TO OR GREATER THAN INDICATED

Figure 5. Distribution of yields from wells completed in different bedrock aquifers in the lower Connecticut River basin. (From Weiss and others, 1982, fig. 35.) 


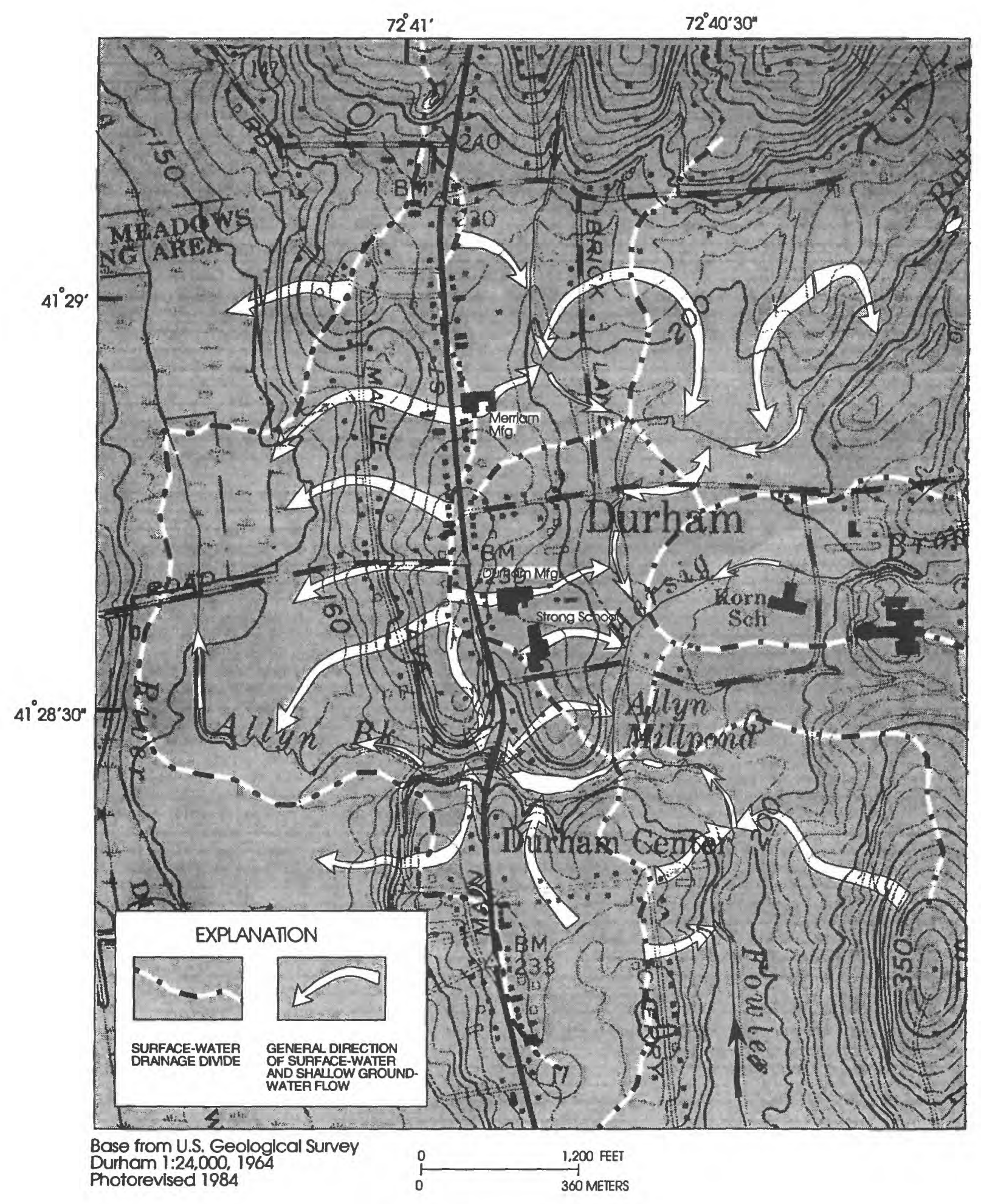

CONTOUR INTERVAL 10 FEET

NATIONAL GEODETC VERTCAL DATUM OF 1929

Figure 6. Idealized surface-water and shallow ground-water circulation pattem in the Durham Center area, Durham, Conn. 
spring located on the Durham-Middlefield town line, was abandoned. The area south of Allyn Brook along Main St., Fowler Ave., and Cherry La. (fig. 1) is served by the Aqua Treatment and Service Co. In 1993, this company obtained its water from Fowler Brook and from a bedrock well (USGS well D-50) but was under orders from the Connecticut Public Utilities Commission to discontinue using Fowler Brook as a supply source.

Water use is mainly for industrial, domestic, and institutional (schools and churches) purposes. The total estimated water use in 1993 was about $26 \mathrm{Mgal}(50 \mathrm{gal} / \mathrm{min})$. The estimated use for each category in 1993 was as follows: domestic--11.3 Mgal; industrial--12.3 Mgal; institutional--2.1 Mgal; other-- $0.5 \mathrm{Mgal}$. These values are based on an estimated household usage of $275 \mathrm{gal} / \mathrm{d}$; metered use by Durham Manufacturing Co. (John Negrich, Durham Manufacturing Co., oral commun., 1994) and Strong School (Leo Baker, Regional School District 13, oral commun., 1994), and estimates made by USGS for Merriam Manufacturing Co. of $2.5 \mathrm{Mgal} / \mathrm{yr}$.

All wastewater, other than industrial wastewater, is discharged to on-site septic systems. The total amount of wastewater that is discharged to the ground is estimated to be almost equal to the total used. Some industrial wastewater from Durham Manufacturing Co. is discharged into an unlined pond east of the plant near Ball Brook. This water is treated by aeration and then reused, although some leakage is likely through the bottom of the pond.

\section{METHODS OF DATA COLLECTION AND ANALYSIS}

The methods used during this study to characterize the geohydrology of the Durham Center area include geologic mapping, surface-geophysical surveys, and borehole-geophysical surveys. Stage-discharge data from streams draining the area and water-level data from wells also were collected and analyzed.
-Principal objectives of the geologic mapping were to determine (1) the bedrock stratigraphy and lithology, and (2) the orientation and frequency of joints and faults.

-Objectives of the surface-geophysical surveys were to (1) detect faults and joints in bedrock and determine their orientations, (2) aid in defining the general stratigraphy of the area, and (3) locate the water table.

-Borehole-geophysical surveys were intended to (1) aid in defining the lithology and stratigraphy of the sedimentary bedrock; (2) detect openings in the bedrock, including faults, joints, and openings along bedding planes; (3) determine the orientation of planar features (faults, joints, and bedding planes); and (4) determine water levels and zones where water is entering or leaving wells.

-Stream-stage and discharge data were collected to (1) develop stage-discharge relations at sites that were related to contaminant discharge or were likely to be water-quality sampling sites, and (2) estimate low-flow frequency and duration of streams draining the study area.

-Water-level data from wells were collected to (1) assess the general nature of the ground-water flow system in the bedrock, including vertical gradients; and (2) determine the effects of manmade and natural stresses on water levels.

\section{Surface Geophysics}

Surface-geophysical surveys were made in the spring and summer of 1993 by the USGS to determine the distribution and orientation of fracture sets within the bedrock, and the distribution and trend of large-scale fracture zones and faults. The surface-geophysical methods were azimuthal, square-array dcresistivity soundings; square-array dc-resistivity traverses (using a fixed-array size); VLFEM traverses; and GPR traverses. The GPR method was unsuccessful for locating the water table or for detection of deeper reflectors 
such as the bedrock surface. The reasons for the lack of radar penetration of the subsurface are unknown, but may be related to the mineral composition of the till. The GPR survey is not discussed further in this report.

\section{Azimuthal, square-array dc-resistivity soundings}

Azimuthal, square-array dc-resistivity soundings are designed to detect the presence and orientation of saturated, steeply dipping fracture sets. In some cases, further analysis of data from these soundings can provide an estimate of the secondary porosity attributable to fracturing (Lane and others, 1995). Data analysis also provides a "layered-earth" interpretation of the subsurface beneath a surveyed site that aids in understanding local stratigraphy.

Azimuthal, square-array dc-resistivity soundings were made at two locations in the study area. Each azimuthal survey consisted of six square-array soundings separated by a $15^{\circ}$ rotational angle about the array centerpoint. The array sizes (A-spacings) were expanded from $16.4 \mathrm{ft}$ to $131.2 \mathrm{ft}$ for each sounding. The data were collected using an ABEM Multimac dc-resistivity system. This is a computercontrolled data acquisition and storage system that allows a complete sounding at a given azimuth to be collected automatically through remotely accessed addressable switchers, which connect the electrodes for a given measurement. The data were analyzed using the techniques described by Lane and others (1995). Layered-earth interpretations were obtained using RESIX-plus, a computer-based interpretation software package.

\section{Square-array dc-resistivity traverses}

Square-array dc-resistivity traverses with a fixed-array size are designed to detect the presence of large-scale fracture zones and faults. The trend of such features is determined by correlating anomalies across multiple parallel traverses. Two parallel square-array traverses were made at a single location in the study area. Data were collected at $65.6 \mathrm{ft}$ intervals using two 131.2-ft-A-spacing square arrays, separated by a rotational angle of $45^{\circ}$. Data were analyzed using methods described by Darboux-Afouda and Louis (1989).

\section{VLF-EM traverses}

VLF-EM surveys can detect anomalies in conductivity caused by large fracture zones and faults. Data were collected every $50 \mathrm{ft}$ along multiple traverses over the study area. The data were collected and analyzed using methods described by Telford and others (1977); more detailed information about this technique can be found in McNeill and Labson (1987).

\section{Borehole Geophysics}

Borehole-geophysical surveys were made in 13 wells in July 1993 by the USGS. The basic logging equipment and the procedures used in borehole logging are described by Keys (1990). Two logging units with different capabilities were used because access to some wells precluded use of a large logging truck. For this reason and others, such as the need to rapidly restore a well to service, the suites of logs are not the same for all wells. The types of logs that were obtained and their applications are summarized in table 1 , and selected logs are in appendix 1. More detailed information on the applications of boreholegeophysical logs to geohydrologic investigation may be found in Keys (1990) and Hearst and Nelson (1985).

The data obtained from most borehole logs (acoustic amplitude and velocity, caliper, focused resistivity, fluid resistivity and temperature, natural gamma, spontaneous potential, single-point resistance, and heat-pulse flowmeter) were recorded and stored electronically in digital format. Paper copies of these logs were made in the field with an analog chart recorder or ink-jet printer. The acoustic televiewer log data were recorded by a video cassette recorder and stored on Beta-format video tape. Acoustic televiewer images were made in the field with a thermal printer. Television images 
were viewed on a color monitor during the logging and were recorded by a video cassette recorder and stored on VHS-format video tape. Copies of all recorded borehole logs are on file at the USGS Connecticut District office in Hartford, Conn.

Only qualitative log analyses were done for this study, largely because of the lack of information about the properties of the rock matrix. More quantitative analysis of these borehole data may be possible if requisite data on rock properties become available. Methods of qualitative and quantitative analyses of logs are described in Keys (1990) and Hearst and Nelson (1985). Qualitative analysis of borehole logs collected at a site in New Jersey where the bedrock geology is similar to that in Durham is described by Williams and Conger (1990).

The primary objectives of the log analysis were to identify the lithology of the sedimentary rocks penetrated by the wells, to correlate stratigraphic units between wells, where possible, and to determine the location and orientation of faults, joints, and bedding planes. Lithologic and stratigraphic interpretations were largely derived from the combined and synergistic analysis of the acoustic televiewer, television, and resistivity logs. The pattern and texture of acoustic-televiewer images and television pictures were related to rock type, as were relative resistivity and acoustic amplitude. Gamma logs were not useful in distinguishing shale from sandstone because of the high potassium content of the arkosic sandstone. The interpretations of the lithology and stratigraphy were aided by lithologic logs compiled from drill cuttings at some wells (Roux Associates Inc., 1990b) and by the regional sedimentology and stratigraphy of the Portland Formation described by LeTourneau (1985).

The acoustic televiewer logs were most useful for determining the location of open planar features that represent joints, faults, and bedding planes. The acoustic televiewer produces oriented photograph-like images of the pattern of acoustic reflectivity of the well bore by recording the ultrasonic reflections as a pulsed-source detector transducer scans the borehole at 3 revolutions per second (Keys, 1990, p. 115). These images were used not only to locate fractures or openings along bedding planes, but also to determine the strike and dip of many of the high-angle planar features using the procedure described by Paillet $(1985$, p. 12).

Other logs that were useful in detecting fractures were caliper, gamma, and acoustic amplitude. Fluid temperature and fluid resistivity logs yielded some qualitative information about the inflow or outflow of water within the well. Heat-pulse flowmeter measurements were subsequently made in several wells at depths above and below fractures or anomalies in fluid temperature and fluid resistivity gradients to determine whether the inflow or outflow of water could be detected under ambient conditions.

\section{Hydrologic Measurements}

Stream stage and stream discharge were measured using established methods described by Buchanan and Somers (1969), Carter and Davidian (1968), and Rantz (1982). Stage was measured at each surface-water gaging site with respect to an established reference point. Two types of current meters were used to measure stream discharge--a standard AA cup meter and a pygmy meter. Small discharges were also measured by using a portable sharpcrested weir. Computed stream discharges were checked and plotted to develop a rating curve for each gaging site. All streamflow records are on file at the USGS District office in Hartford, Conn.

Water levels in observation wells were measured using a float-counterweight system connected to a Fischer Porter punch-tape recorder. Measurements were also made with a chalked steel tape with $0.01-\mathrm{ft}$ gradations to verify the accuracy of the automatic recorders. All recorded water levels were entered into a USGS computerized data base. 


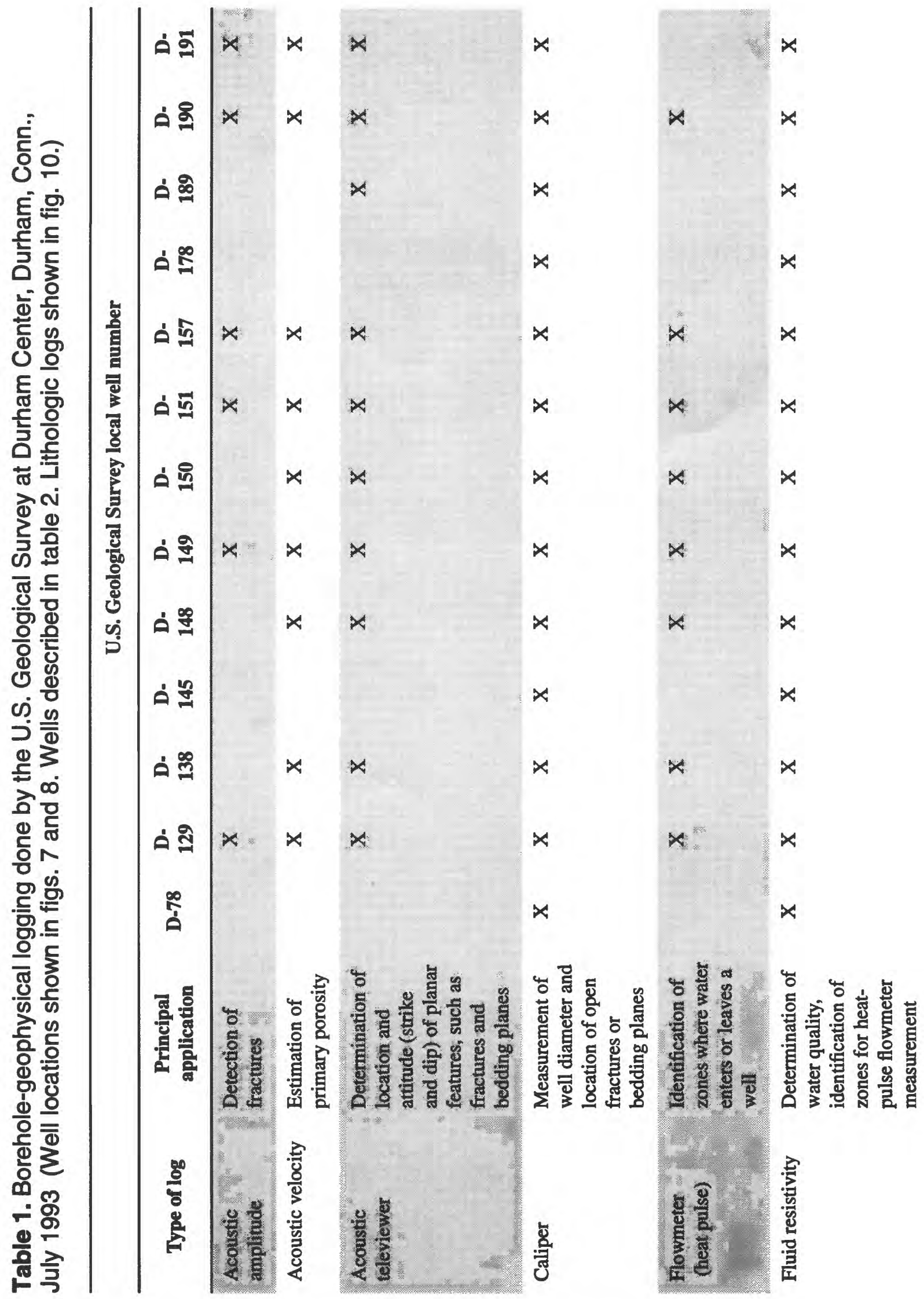




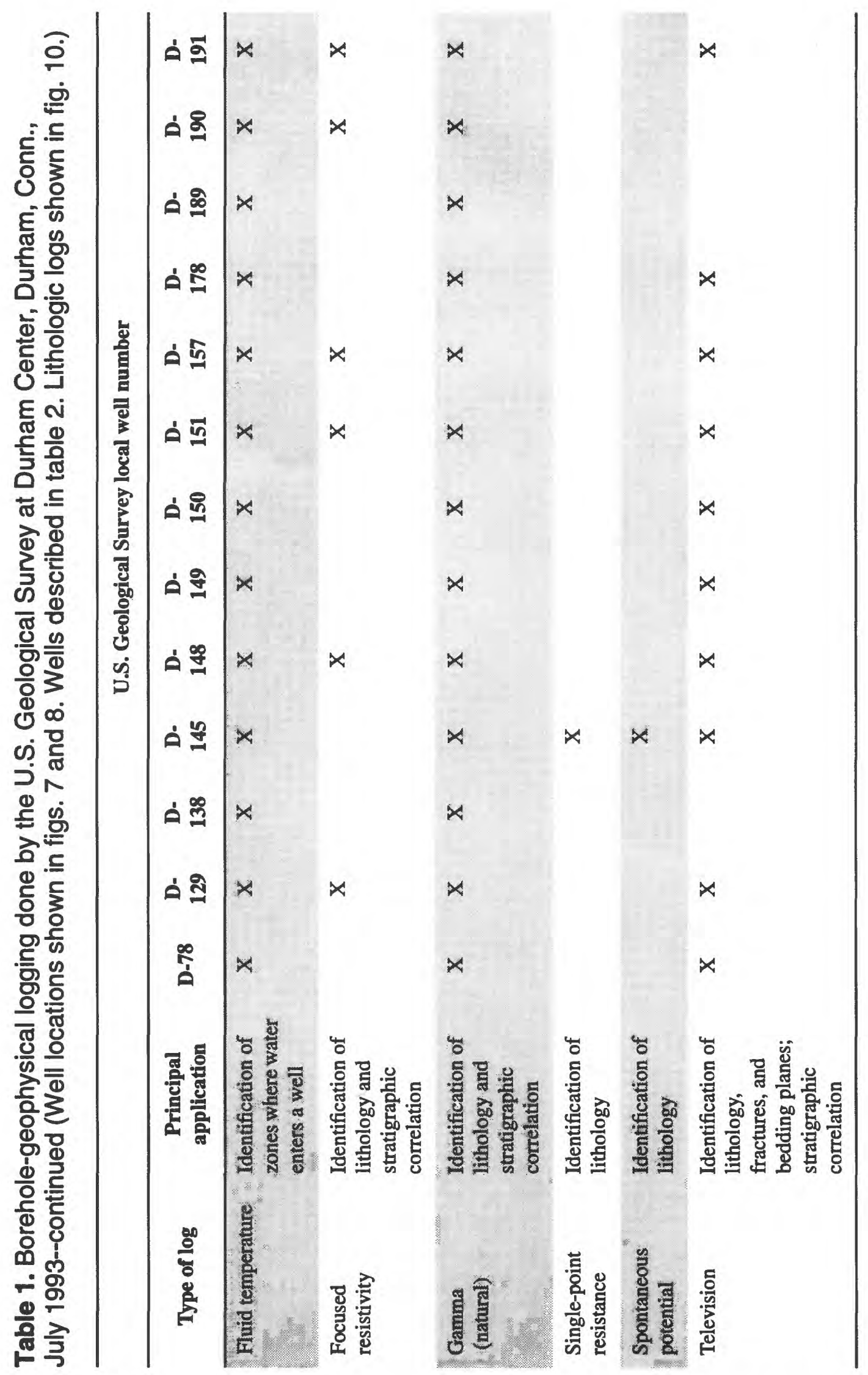




\section{GEOHYDROLOGY OF THE DURHAM CENTER AREA}

The regional and local geohydrology of this area is complex with regard to the lithology and hydraulic properties of the unconsolidated deposits and sedimentary rocks, the structural features of the bedrock, and the movement of ground water. Two of the geohydrologic units in the Durham Center area, till and sedimentary bedrock, are the principal media for the storage and transport of the organic chemicals that have caused widespread degradation of the ground water. Surficial exposures of these units are rare in the study area, and most of the information about the units has been obtained from well records, hydraulic tests and borehole-geophysical measurements in wells, and samples taken from test pits or borings, or has been extrapolated from the study of similar materials in the region.

An extensive effort was made to obtain records of wells located in or near Durham Center. Although many well records were found in publications and agency files, no records were available for 42 homes and other buildings known or believed to have wells (including several that have water-quality data). The USGS located and inventoried the wells for which some information on construction characteristics, yield, or geology was found. These wells are shown in figure 7 and are listed in table 2, with available information on their construction characteristics, water level, depth, and depth to bedrock. The information for the inventoried wells was entered into the USGS computerized Ground-Water Site Inventory (GWSI) data base.

\section{Geohydrologic Units}

\section{Stratified Drift}

Stratified drift is present only in the lowlying areas beneath Ball Brook-Hersig Brook valley to the east, and Durham Meadows to the west of Durham Center (units $\mathrm{f}, \mathrm{s}$, and sg shown in fig. 3b). Beneath these areas, stratified drift consists predominantly of finegrained glaciolacustrine sediment including very fine sand, silt, and clay (fine-grained deposits in fig. 3b). The sediment is at least in part varved; that is, it is present in thin, rhythmically laminated, alternating silt and clay layers. Surface exposures of varved silt and clay were reported in the Ball Brook-Hersig Brook valley by Simpson (1968b); and are also recorded in the logs of some wells and test holes from Durham Meadows.

The surface altitude of the fine-grained deposits is at 180 to $190 \mathrm{ft}$ in Hersig Brook valley and at 150 to $160 \mathrm{ft}$ in the Coginchaug River valley (Durham Meadows). Glaciolacustrine sediment is as much as $50 \mathrm{ft}$ thick in the Hersig Brook valley and as much as $100 \mathrm{ft}$ thick beneath Durham Meadows. Locally, thin units of coarser-grained sand and gravel overlie the fine-grained deposits in both valleys (fig. $3 \mathrm{~b}$ and $3 \mathrm{c}$ ); these materials were deposited either as alluvial fans on the drained glacial lake bed or as floodplain alluvium along modern streams incised into the lake bed.

Extensive, marshy areas along the Coginchaug River in Durham Meadows are underlain by thick swamp deposits--peat and organic muck that have accumulated in a highwater-table environment on top of the glacial lake sediments during postglacial time.

The hydraulic properties of the finegrained stratified drift have not been measured in this area, and measurements elsewhere in Connecticut are sparse. Laboratory-determined values of hydraulic conductivity and storativity for fine-grained glaciolacustrine sediments compiled by Melvin and others (1992b) are shown below. 


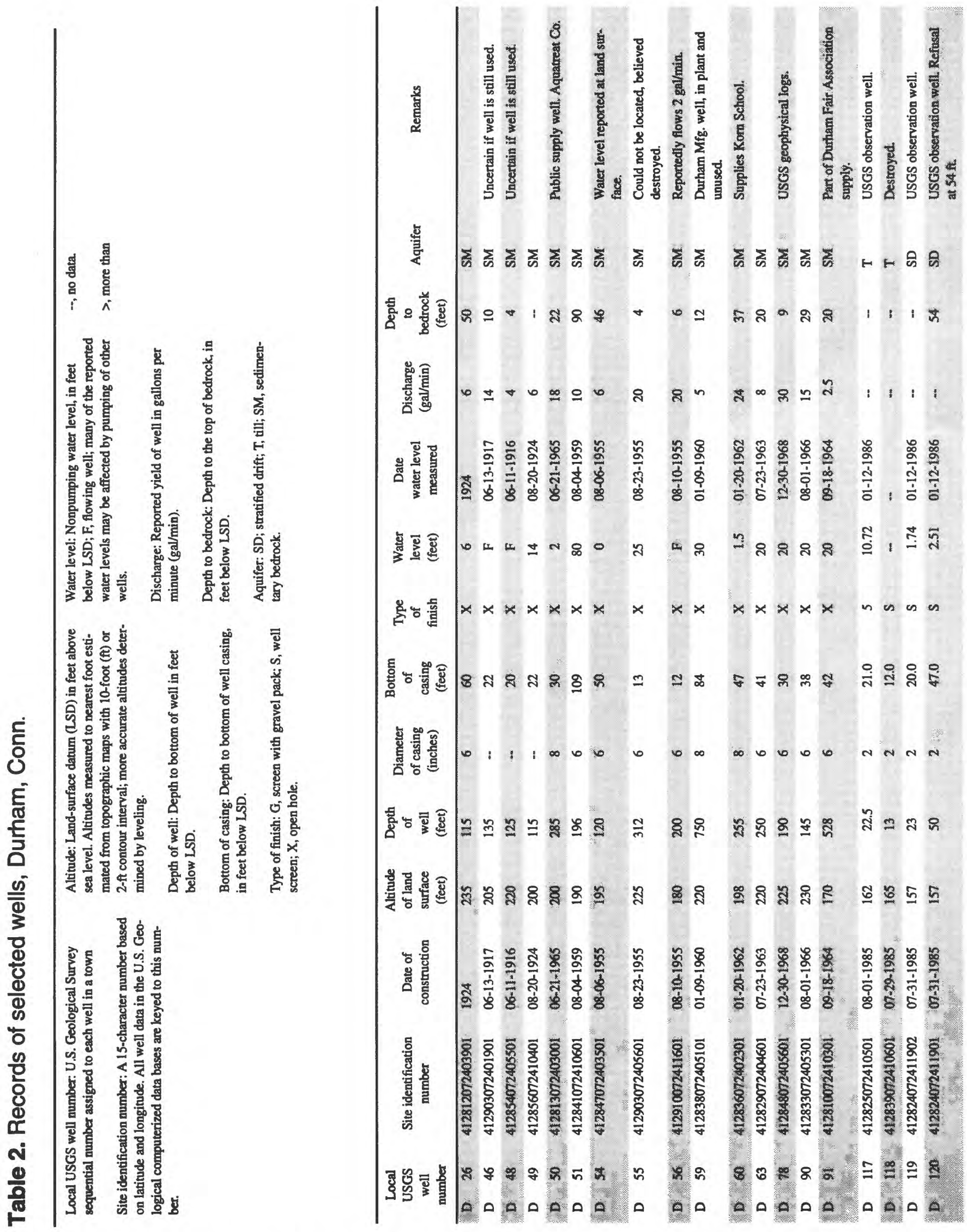




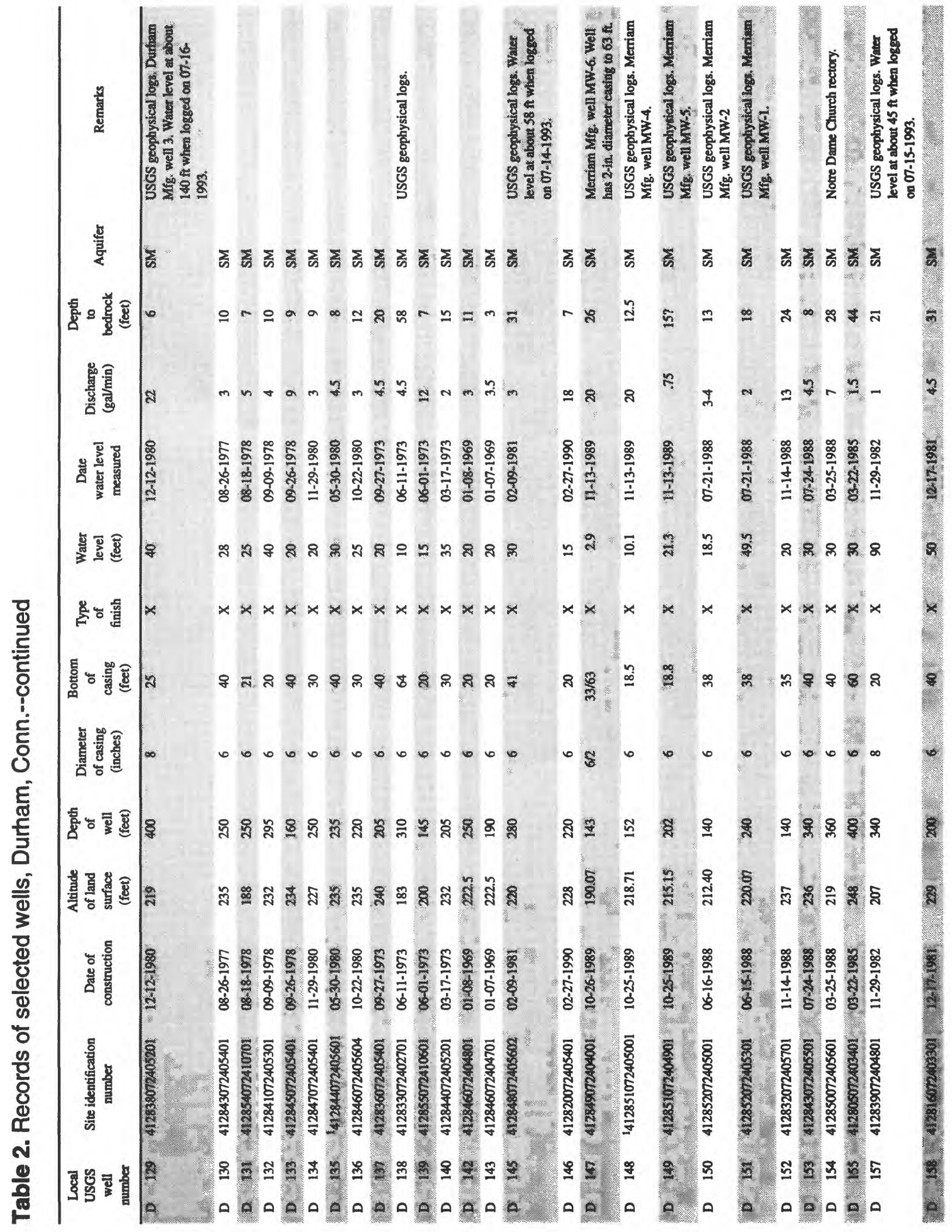




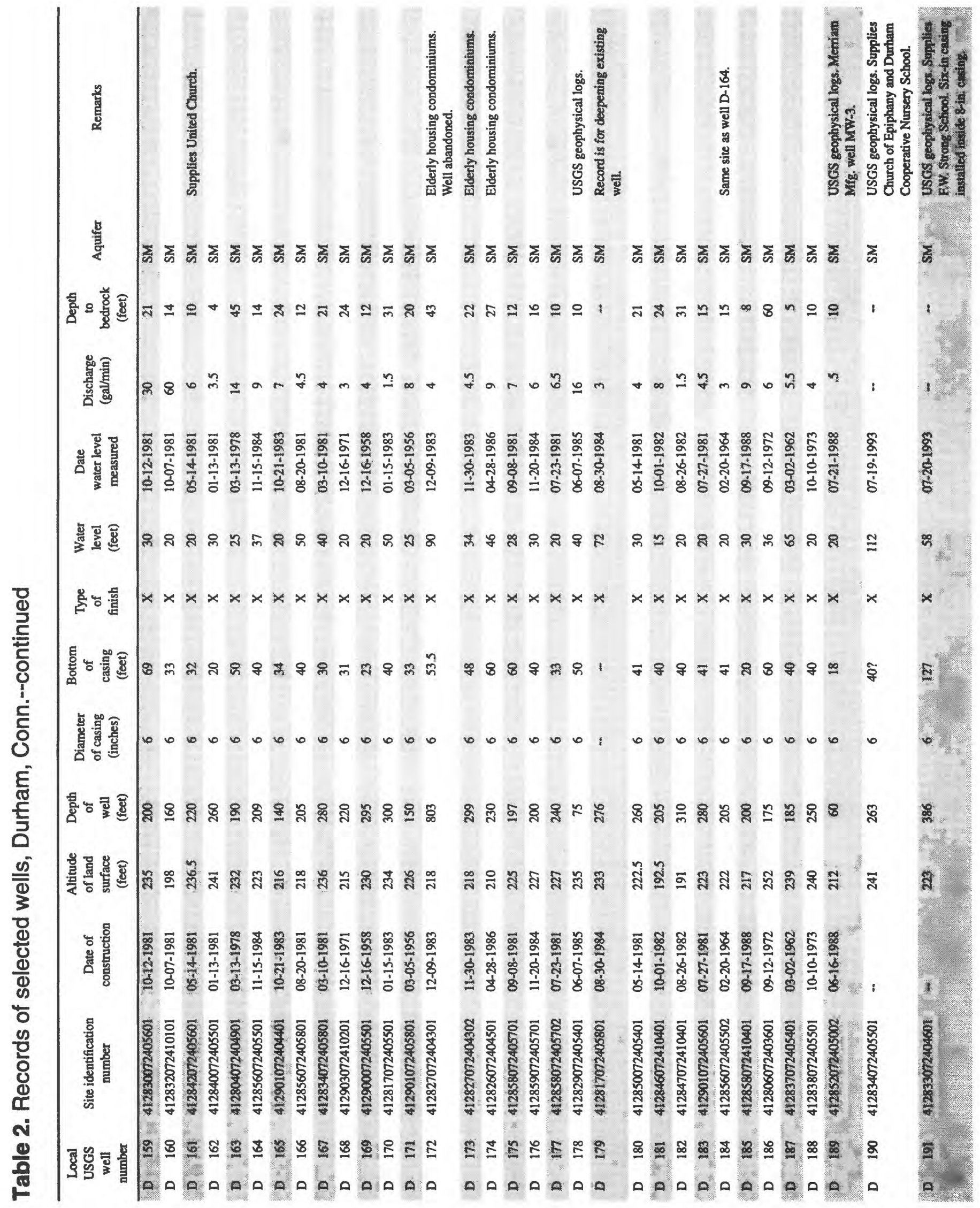




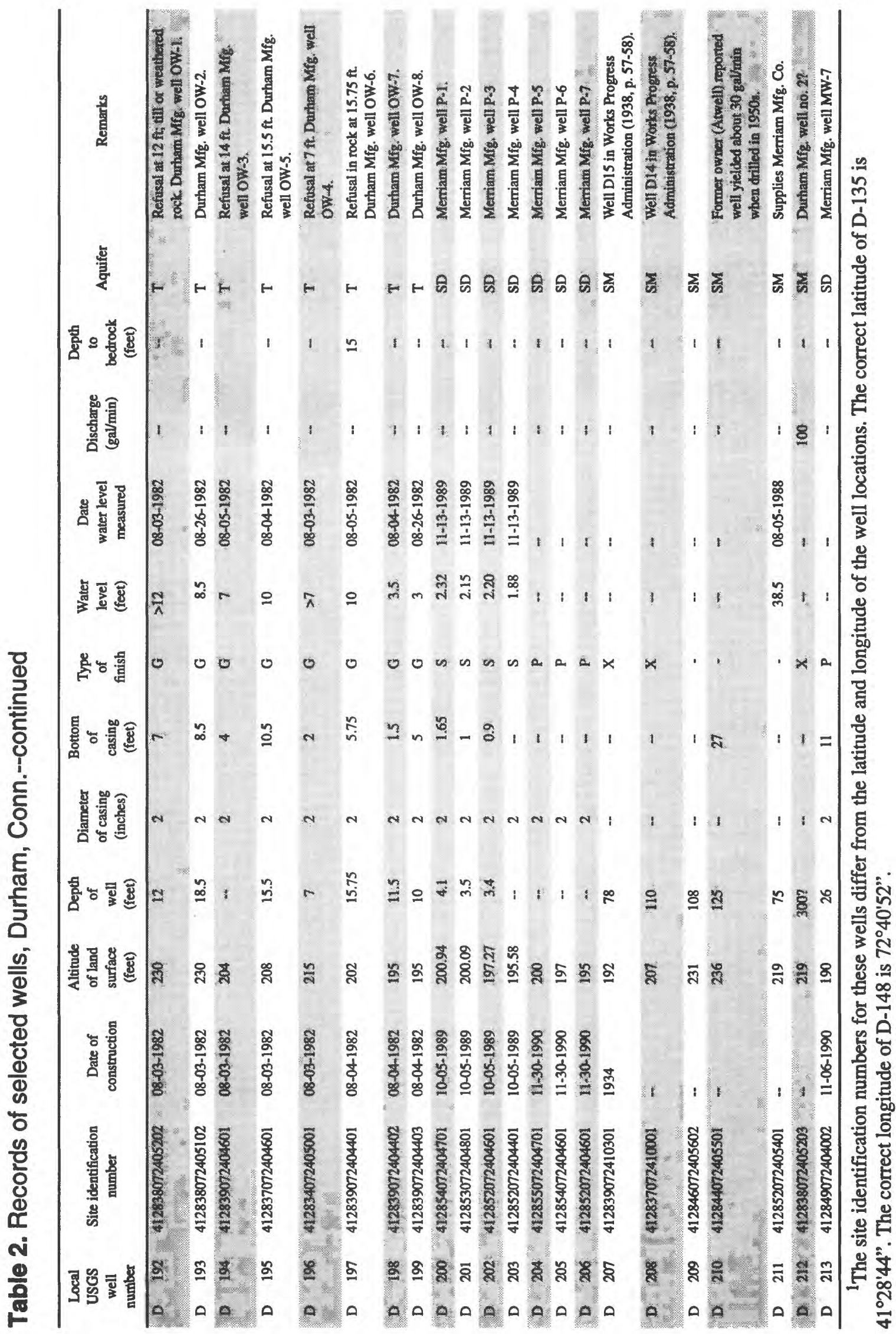


Unit and thickness

Median hydraulic

conductivity (feet per day)

Six undisturbed samples

of lake silts, oriented vertically

Three undisturbed samples

of varved clay, oriented vertically

Three undisturbed samples

of varved clay, oriented horizontally
0.14

.0001

not determined
Median storativity

(dimensionless)
Till

Till is the surface geologic unit over most of the Durham Center area (fig. 3b); it mantles the bedrock surface in thicknesses generally ranging from 5 to $30 \mathrm{ft}$ (fig. 8). Locally, on the west side of Durham Center, till is as thick as $90 \mathrm{ft}$. Old records of dug wells (Brown, 1928; Works Progress Administration, 1938) at Durham Center show depths to the water table ranging from 2.3 to $26 \mathrm{ft}$, and the saturated thickness is estimated to be less than $20 \mathrm{ft}$ throughout most of the area, even during periods when the water table is higher than average. At Merriam Manufacturing Co., the till in some borings and test pits was unsaturated and the water table was located in the underlying bedrock (Roux Associates Inc., $1983,1988,1990 b)$. The water table may be below the bedrock surface at other places where the till is thin. The position of the water table in till can fluctuate several feet as shown by the hydrograph of USGS well D-117 (fig.9), west of Durham Center. Consequently, the water table may move back and forth between the till and bedrock annually or less frequently.

The till in the Durham area was deposited predominantly as lodgment till beneath continental ice sheets during the late Wisconsinan and earlier (Illinoian) glaciations. Its color and lithology closely resemble the underlying sedimentary bedrock from which it was derived. The till is red brown and consists of a nonsorted, nonlayered mixture of grain sizes with a matrix of 50 to 60 percent sand, 30 to 40 percent silt, and 10 to 15 percent clay; larger rock fragments (clasts) generally constitute 10 to 20 percent of the total volume of the material (Melvin and others, 1992b). This red brown till is relatively hard, dense, and compact; this is partly due to its subglacial origin but also to its higher silt and clay content, as compared to gray tills of the Eastern Highland areas that are derived from crystalline rocks. The till is fractured in many places; some fractures are stained with iron or manganese, making them more visible in section. No surface exposures of till were available in the Durham Center area during the time of this study; however, a previous exposure of till at the DurhamMiddlefield landfill (1 mi northwest of Durham Center) was examined, sampled, and described by USGS personnel in 1985-86. That till was very dense, and closely spaced, dark-stained joints were common; spacing between joints ranged from less than 1 in. to several inches. Horizontal or subhorizontal joints were most common and, together with the less-common vertical joints, formed jointbounded blocks of till that could be excavated from the exposure.

Some measurements of the hydraulic properties of till were made in or near the Durham Center area. Aquifer tests were done on wells tapping the till at Durham Manufacturing Co. by Leggette, Brashears, and Graham, Inc. (1982), and laboratory measure- 
ments were made on till samples from USGS test holes about $0.5 \mathrm{mi}$ southeast of Durham Center. These data are summarized in table 3. The hydraulic conductivities determined from the aquifer tests are higher than the laboratorydetermined values, and this relation is consistent with observations made elsewhere (Stephenson and others, 1988, table 3). The difference in hydraulic conductivity measured by field and laboratory tests is generally ascribed to the till having both primary (intergranular) hydraulic conductivity and secondary hydraulic conductivity produced by fractures or other types of secondary openings. Laboratory tests commonly measure only the primary hydraulic conductivity of a till matrix.
Aquifer tests, such as those done by Leggette, Brashears, and Graham, Inc. (1982), however, are more likely to measure the hydraulic conductivity of the "bulk mass" of till that includes fractures or other secondary openings. Because these aquifer tests were conventional single-well response (slug) tests, they may also have underestimated the hydraulic conductivity of the bulk mass of a fractured till (D'Astous and others, 1989; Keller and others, 1989).

Hydraulic conductivity, porosity, and hydraulic gradient are commonly used to estimate the average linear velocity of water moving through granular materials such as till. The porosity values in table 3 are laboratory

Table 3. Hydraulic properties of till, Durham, Conn.

[b, hydraulic conductivity of bulk mass of till; $m$, hydraulic conductivity of the till matrix; USGS, U.S. Geological Survey; ft, feet; $\mathrm{ft} / \mathrm{s}$, feet per second; ft/d, feet per day; $\mathrm{cm} / \mathrm{s}$, centimeters per second; --, no data]

\begin{tabular}{|c|c|c|c|c|}
\hline Location & $\begin{array}{l}\text { Type of test and } \\
\text { method of analysis }\end{array}$ & $\begin{array}{c}\text { Hydraulic } \\
\text { conductivity } \\
\text { (feet per day) }\end{array}$ & $\begin{array}{l}\text { Porosity } \\
\text { (percent) }\end{array}$ & Remarks \\
\hline $\begin{array}{l}\text { Durham Manufacturing } \\
\text { Co. monitoring wells } \\
\text { OW-3 and OW-7 (USGS } \\
\text { wells D-194 and D-198) }\end{array}$ & $\begin{array}{l}\text { Single-well response } \\
\text { (slug) test. Analyzed } \\
\text { using method described } \\
\text { by Hvorslev (1951) }\end{array}$ & 0.22 to 0.57 (b) & - & $\begin{array}{l}\text { Leggette, } \\
\text { Brashears, and } \\
\text { Graham, Inc. } \\
(1982) \text {. Values } \\
\text { are converted } \\
\text { from ft/s to ft/d. }\end{array}$ \\
\hline $\begin{array}{l}\text { Durham Manufacturing } \\
\text { Co. monitoring wells } \\
\text { OW-2, OW-6, and OW-8 } \\
\text { (USGS wells D-193, } \\
\text { D-197, and D-199) }\end{array}$ & $\begin{array}{l}\text { Single-well response } \\
\text { (slug) test. Analyzed } \\
\text { using method described } \\
\text { by Papadopolous and } \\
\text { others (1973) }\end{array}$ & .04 to 2.4 (b) & -- & Do. \\
\hline $\begin{array}{l}\text { Cherry Lane, Durham, } \\
\text { Comi, } 16 \text { core samples } \\
\text { from USGS test holes } \\
\text { D-14TH and D-15TH. } \\
\text { Samples are from } 2.6 \text { to } \\
24.3 \text { ft below land surface }\end{array}$ & $\begin{array}{l}\text { Constant-head } \\
\text { permeameter tests } \\
\text { measuring vertical } \\
\text { hydraulic conductivity }\end{array}$ & .0005 to $0.05(\mathrm{~m})$ & 21 to 28 & $\begin{array}{l}\text { Melvin and } \\
\text { others (1992a). } \\
\text { Values are } \\
\text { converted from } \\
\mathrm{cm} / \mathrm{s} \text { to } \mathrm{ft} / \mathrm{d}\end{array}$ \\
\hline $\begin{array}{l}\text { Durham-Middlefield } \\
\text { landfill, Durham, Conn.; } \\
3 \text { core samples from deep } \\
\text { trench }\end{array}$ & $\begin{array}{l}\text { Constant-head } \\
\text { permeameter tests } \\
\text { measuring vertical } \\
\text { hydraulic conductivity }\end{array}$ & .014 to $0.07(\mathrm{~m})$ & 32 to 27 & Do. \\
\hline
\end{tabular}




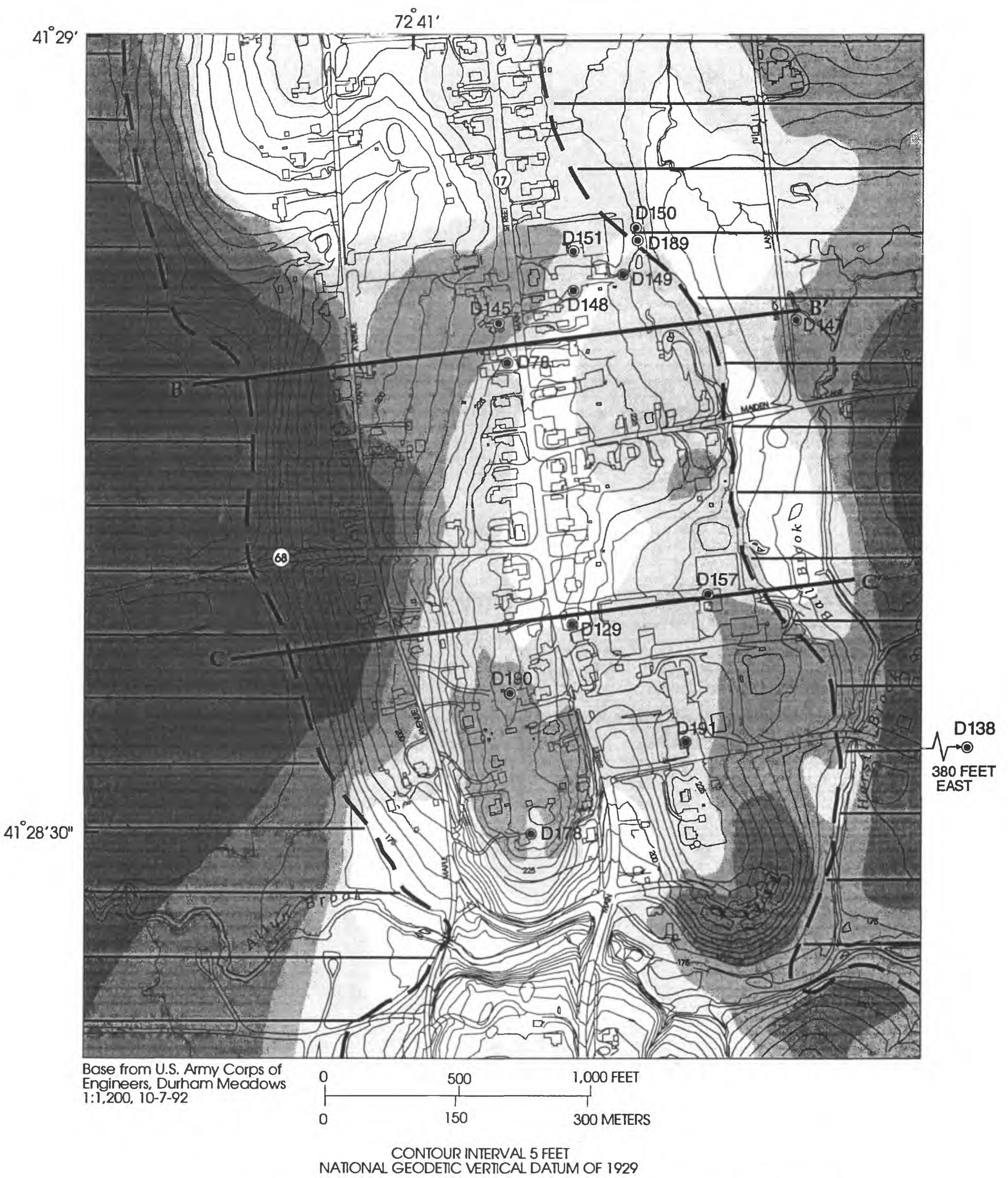

Figure 8. Depth to bedrock at Durham Center, Durham, Conn. 


\section{EXPLANATION}

\section{DEPTH TO BEDROCK}

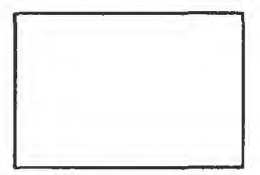

Less than 10 feet

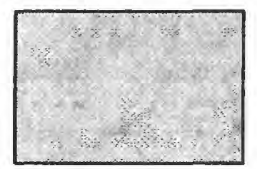

10 - 20 feet

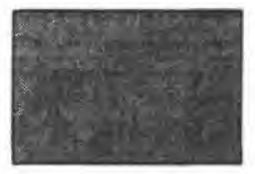

$21-30$ feet

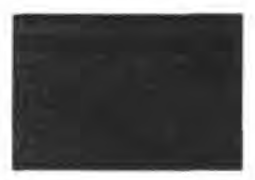

31 - 50 feet

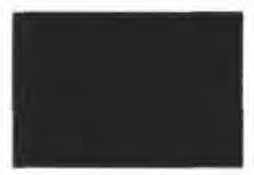

$51-100$ feet

D145 Wells in which borehole-geophysical logs were obtained (logs shown in appendlx 1)

B - Line of section for geologic sections B-B' and C-C' shown in figure 11

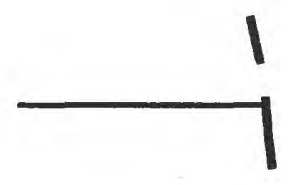

Areas underlain by stratified drlft
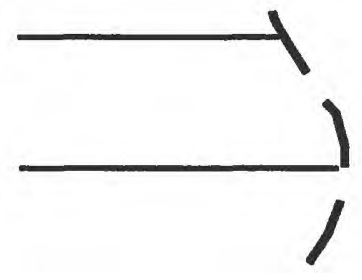


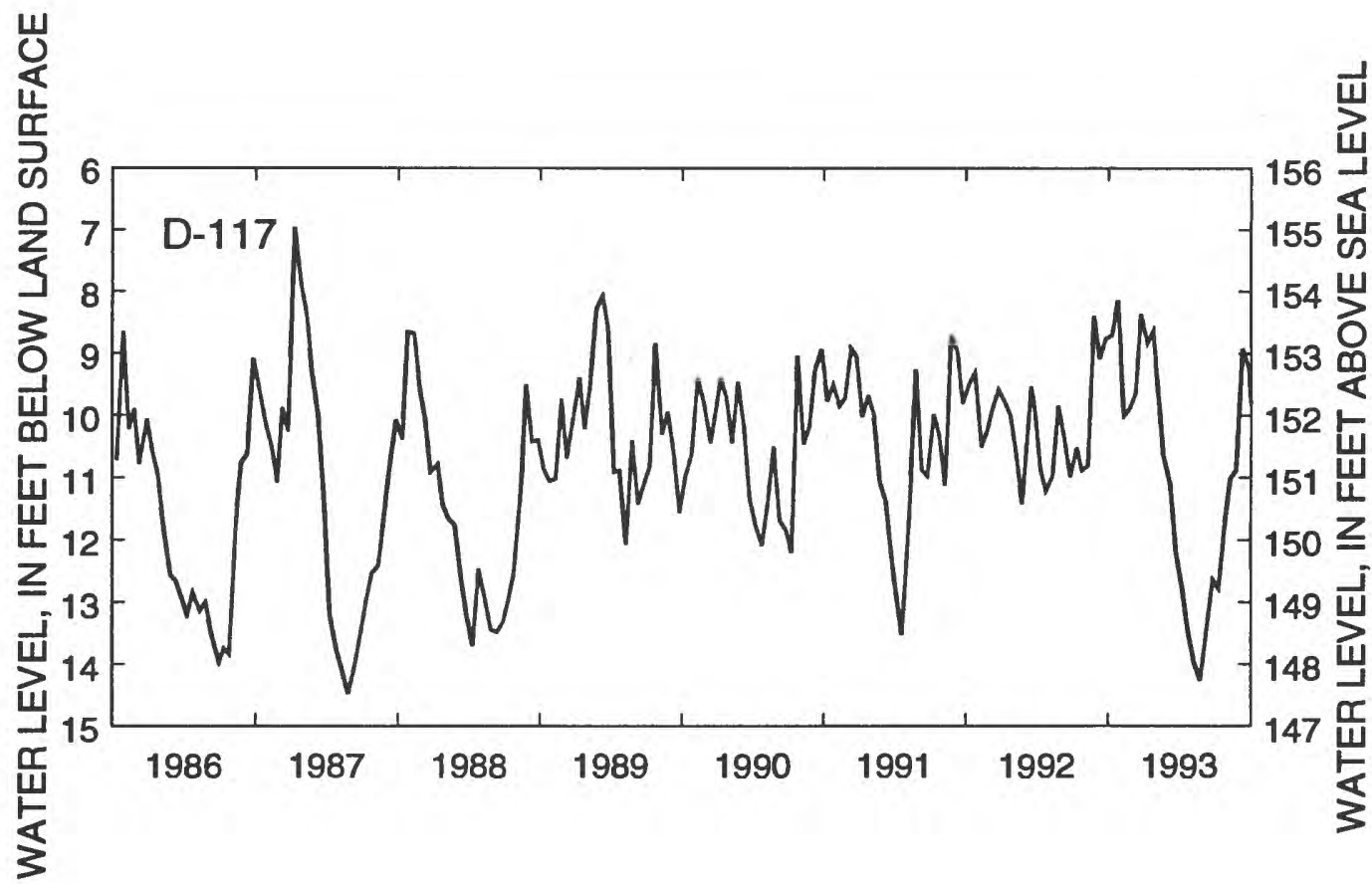

Figure 9. Water levels in U.S. Geological Survey observation well D-117, Durham, Conn.

measurements of total intergranular pore space--porosities resulting from fractures in till are much lower, and may be less than 1 percent (Grisak and others, 1976, p. 320). If the till in the Durham Center area is fractured, as is likely, the velocities of flowing ground water would be considerably greater than estimates based on intergranular porosity.

\section{Bedrock}

Sedimentary bedrock of the Portland Formation is the major geohydrologic unit in the Durham Center area (fig. 3a and 3c). Nearly all the wells in the area penetrate and are cased through the glacial sediments and withdraw water from the bedrock (table 2). The yields of these wells range from less than 1 to as much as $100 \mathrm{gal} / \mathrm{min}$.

\section{Stratigraphy, Lithology and Mineralogy}

Bedrock is mapped as Portland Formation on geologic maps (Simpson, 1968a; Rodgers, 1985); however, LeTourneau (1985) further subdivided conglomerate, sandstone, siltstone, and shale lithofacies within the Portland Formation and mapped the Durham Center area as underlain by pebbly sandstone and siltstone. He also inferred the presence of a lacustrine black shale unit at depth by stratigraphic projection of a black shale unit exposed in Laurel Brook, approximately $2 \mathrm{mi}$ to the north. The classification scheme of the lithofacies within the Portland Formation presented by LeTourneau (1985), and slightly modified by Horne and others (1993), is used to describe lithologic units in this report. Stratigraphic correlation of lithologic units within the Portland Formation must take into account (1) spatial relations between lithofa- 
cies within a stratigraphic unit due to local depositional environment; (2) vertical changes in the rock sequence caused by oscillations in climatic conditions during Early Jurassic time; (3) the changing positions of lakes, river floodplains, and alluvial fans caused by basin subsidence; and (4) post-depositional structural effects. The structural effects include minor folding, but more significantly, extensional and compressional faulting, that has resulted in the formation of fault blocks within the basin. Stratigraphic units have been vertically displaced hundreds of feet across the high-angle normal faults. (See fig. 3c.)

Exposures of bedrock examined during this investigation and earlier studies (fig. 3a) lie outside of the immediate Durham Center area, which is entirely covered by glacial deposits (fig. 8). Consequently, the lithology and stratigraphy of rock units beneath Durham Center has been interpreted largely from borehole-geophysical logs (appendix 1) collected at the 13 wells shown in figure 8. The downhole TV camera and acoustic televiewer logs were particularly useful for identifying lithologic units in the wells (fig. 10). Lithologic units were assigned to subfacies as defined by LeTourneau (1985). Correlation of units between wells is shown in two east-westtrending geologic sections (fig. 11), each approximately $2,000 \mathrm{ft}$ long. The northern section (labeled B-B' in fig. 11) crosses Main Street near Merriam Manufacturing Co. and the southern section, labeled C-C' in figure 11, crosses Main Street at Durham Manufacturing Co. Lithologic units beneath Durham Center within the depth range of the borehole logs, approximately $400 \mathrm{ft}$, include the following subfacies of LeTourneau (1985) as modified by Horne and others (1993):

- Subfacies 3-fine conglomerate and pebbly sandstone in trough and planar crossstratified beds deposited by braided streams in mid-distal alluvial fan environments

- Subfacies 4-silty fine sandstone with thin granule beds consisting of thin, planar and ripple cross-stratified, commonly poorly sorted beds deposited by shallow streams and sheet floods in distal alluvial fan environments

- Subfacies 5-medium to coarse sandstone with interbedded siltstone in trough cross-stratified beds deposited by ephemeral braided streams on desiccated floodplains on the basin floor

- Subfacies 6-siltstone with interbedded medium to coarse sandstone and mudstone deposited by perennial meandering rivers on the basin floor

- Subfacies 7-gray siltstone with interbedded ripple-cross-laminated sandstone deposited near shorelines and in shallow water of lakes

- Subfacies 8-dark siltstone and laminated black shale deposited in deep-water areas of perennial lakes.

In the process of borehole-log interpretation, coarse-grained lithologic units were most easily identified as a particular lithofacies because individual grains could be seen. The lacustrine units were easily distinguished as well because of their distinctive sedimentology and gray and black color. The specific lithologies of the red fine-grained units were more difficult to define in the absence of rock cores and outcrop data. The red fine-grained units are most likely to be subfacies 6 (siltstone with interbedded sandstone and mudstone) on the basis of the "wet-phase" depositional model of facies assemblages (LeTourneau, 1985; Horne and others, 1993; Hubert and others, 1978). Descriptions of drill cuttings in these zones from the wells at Merriam Manufacturing Co. (Roux Associates Inc., 1990b) include "siltstone," "silty sandstone," and "very fine sandstone, siltstone, and shale." Some parts of the "fine-grained" units seen in the well logs may actually be silty fine sandstone of subfacies 4 . As can be seen on sections B-B' and C-C' (fig. 11), the stratigraphic section beneath Durham Center includes two gray and black 

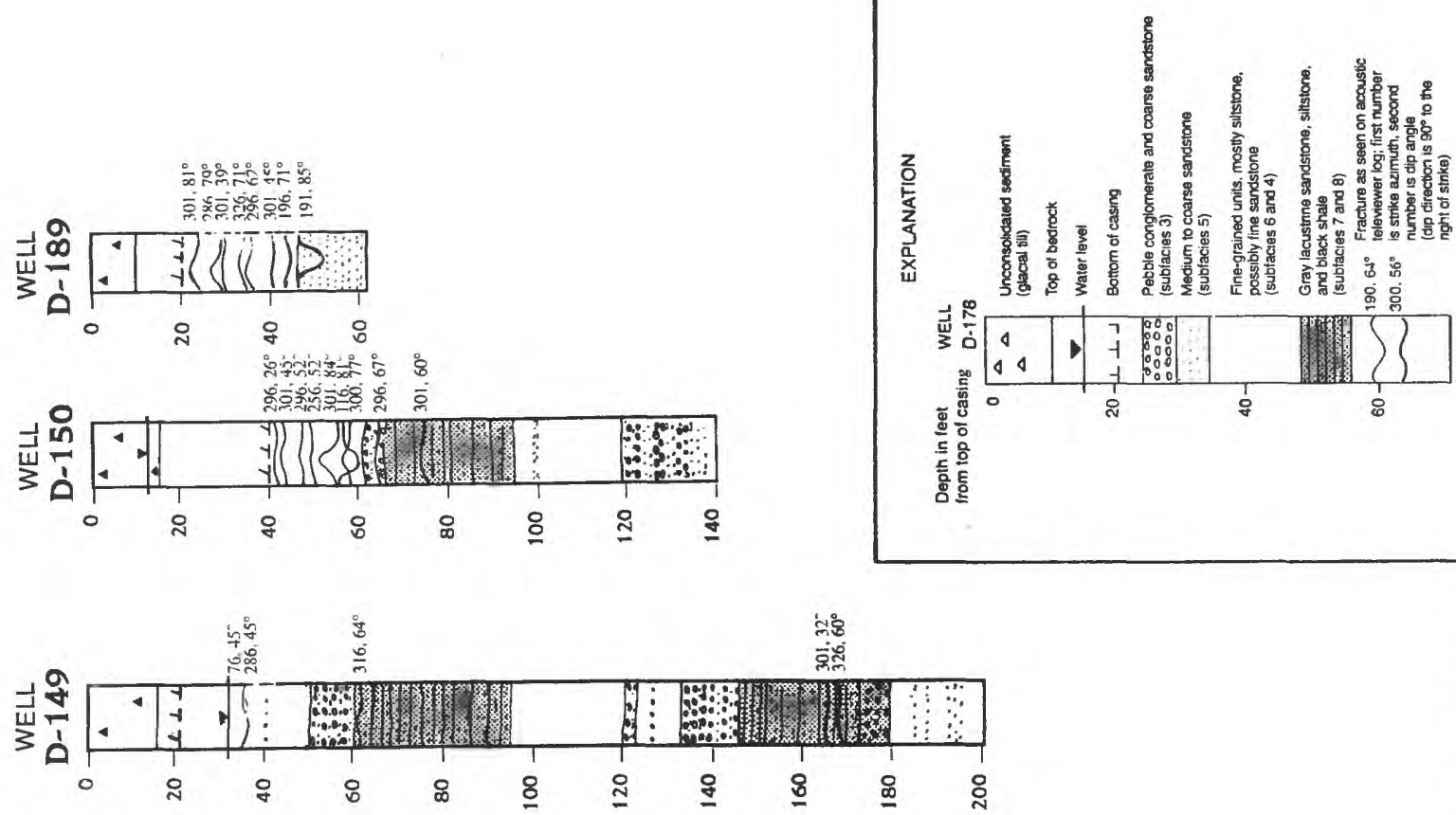

它
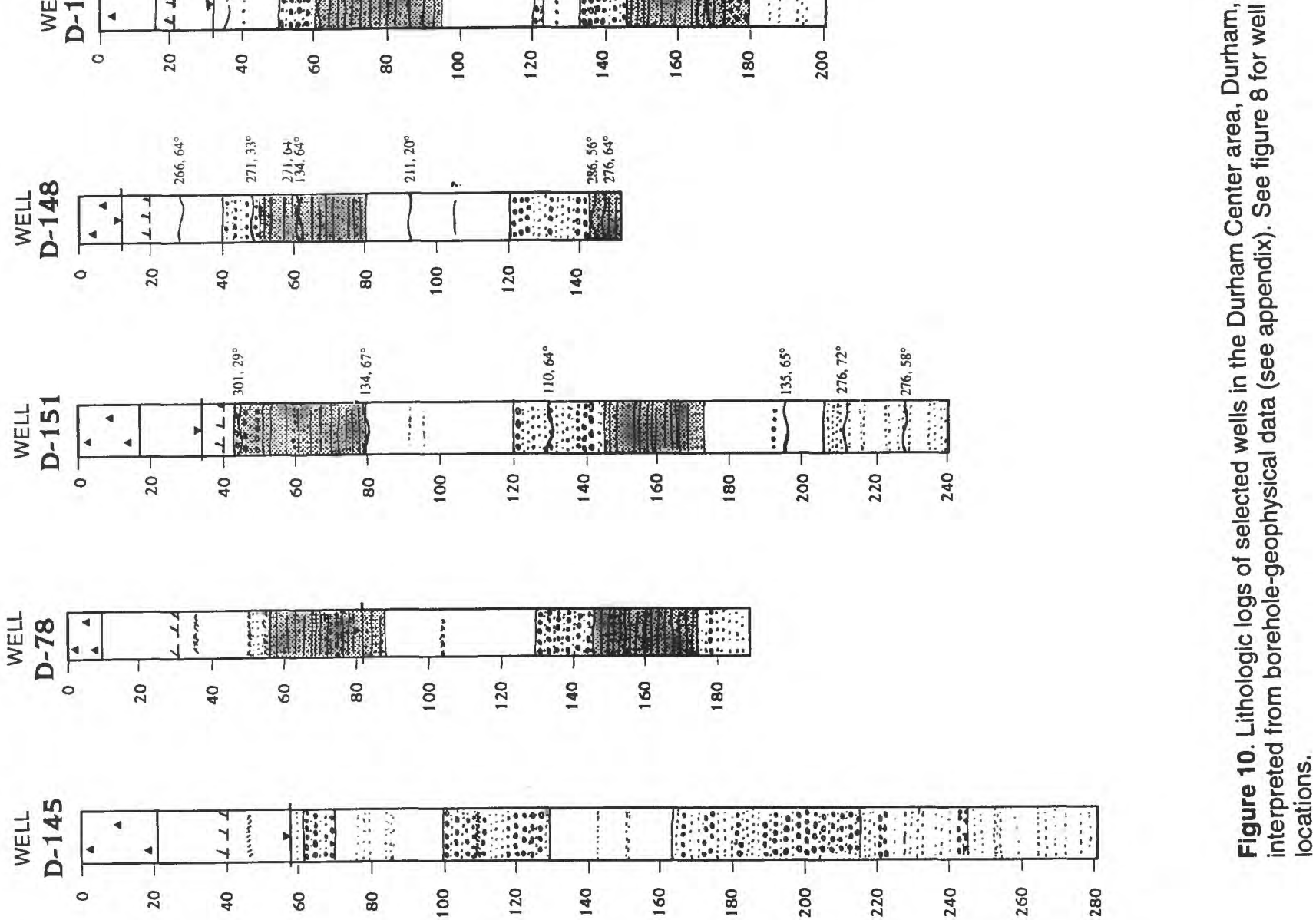

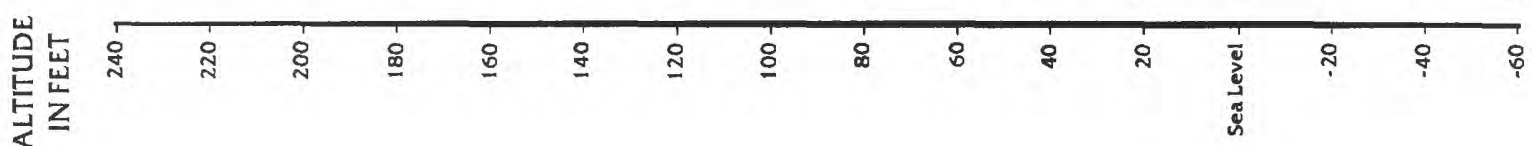




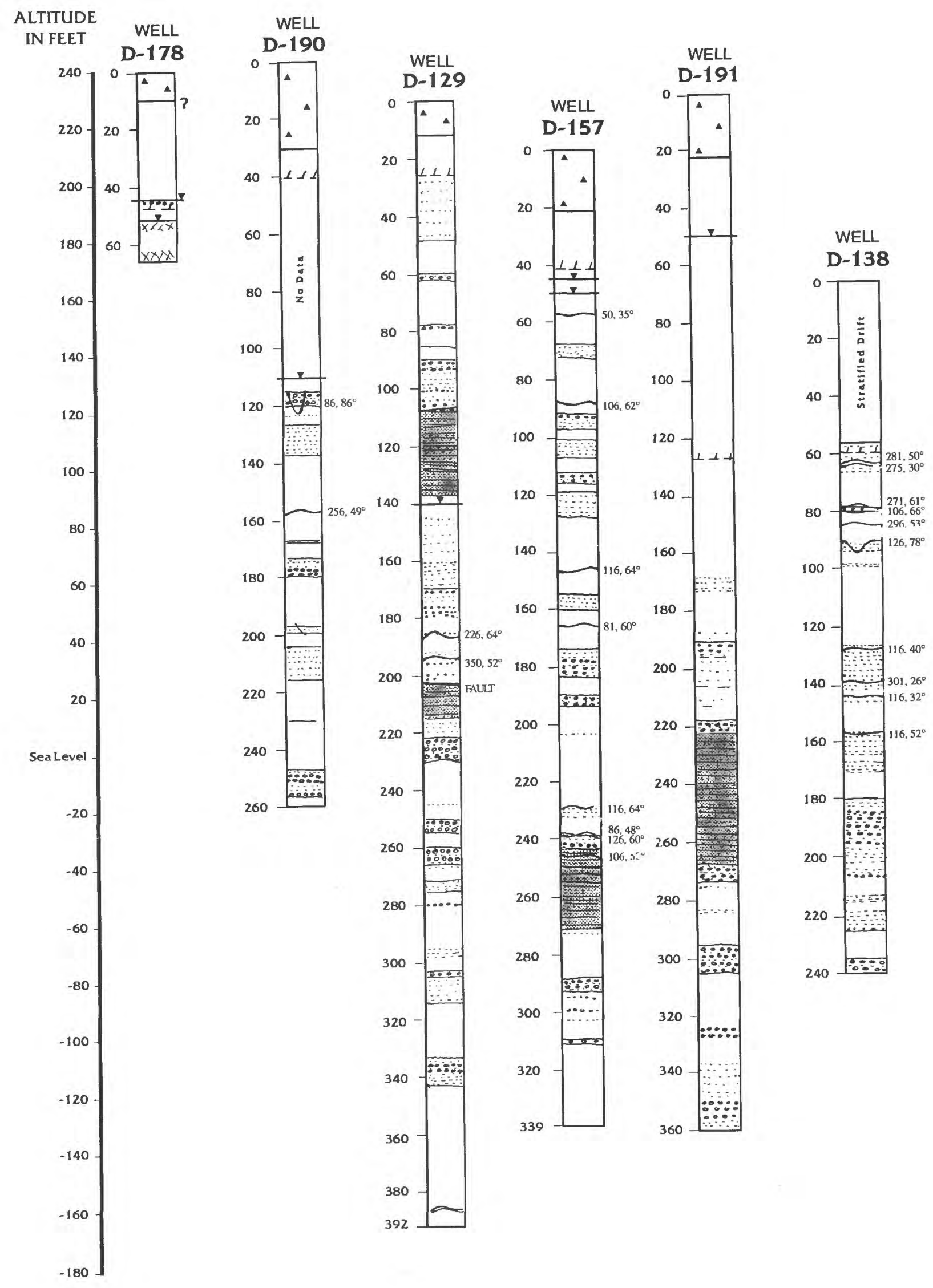

Figure 10. Lithologic logs of selected wells in the Durham Center area, Durham, Conn., interpreted from borehole-geophysical data--continued 


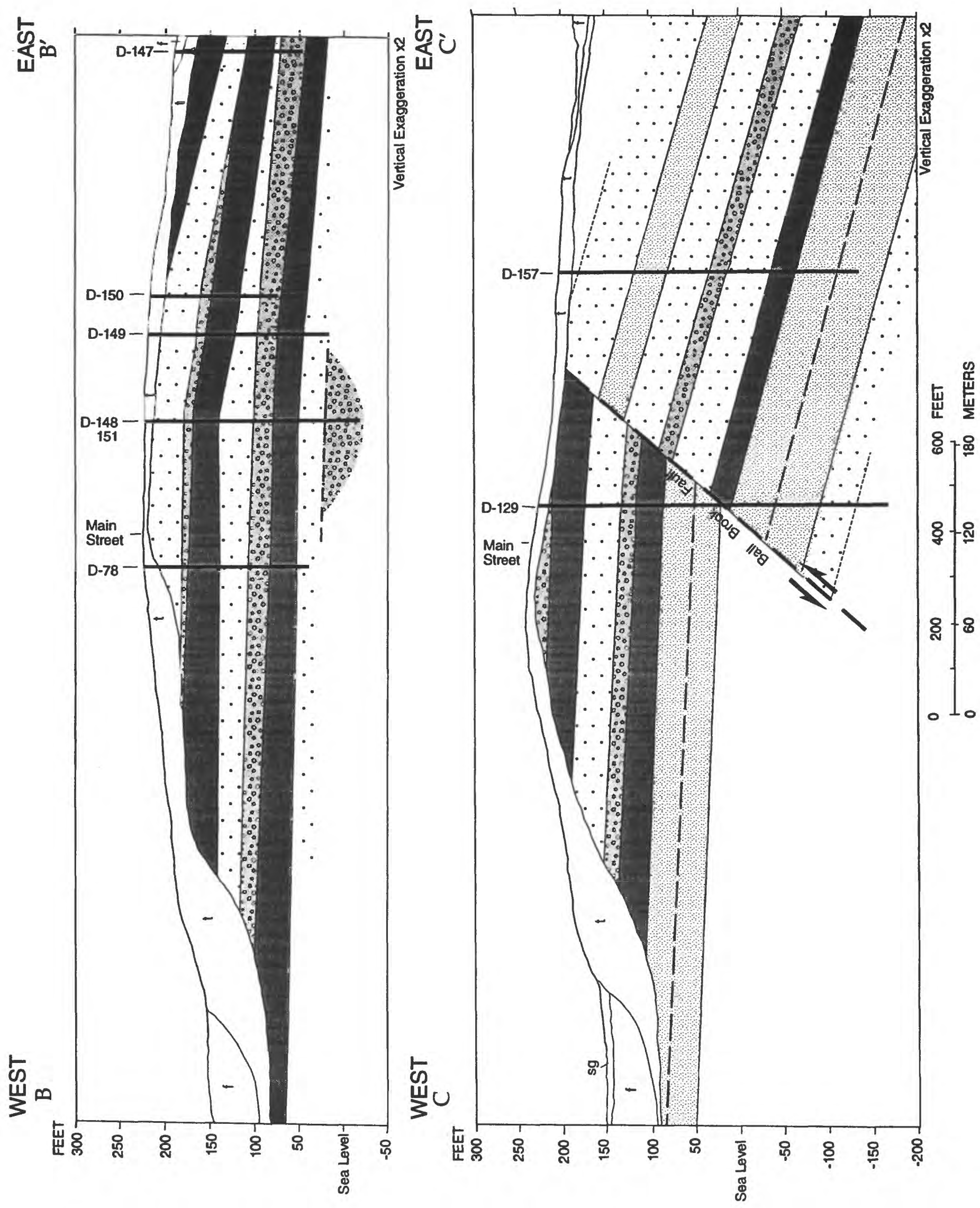




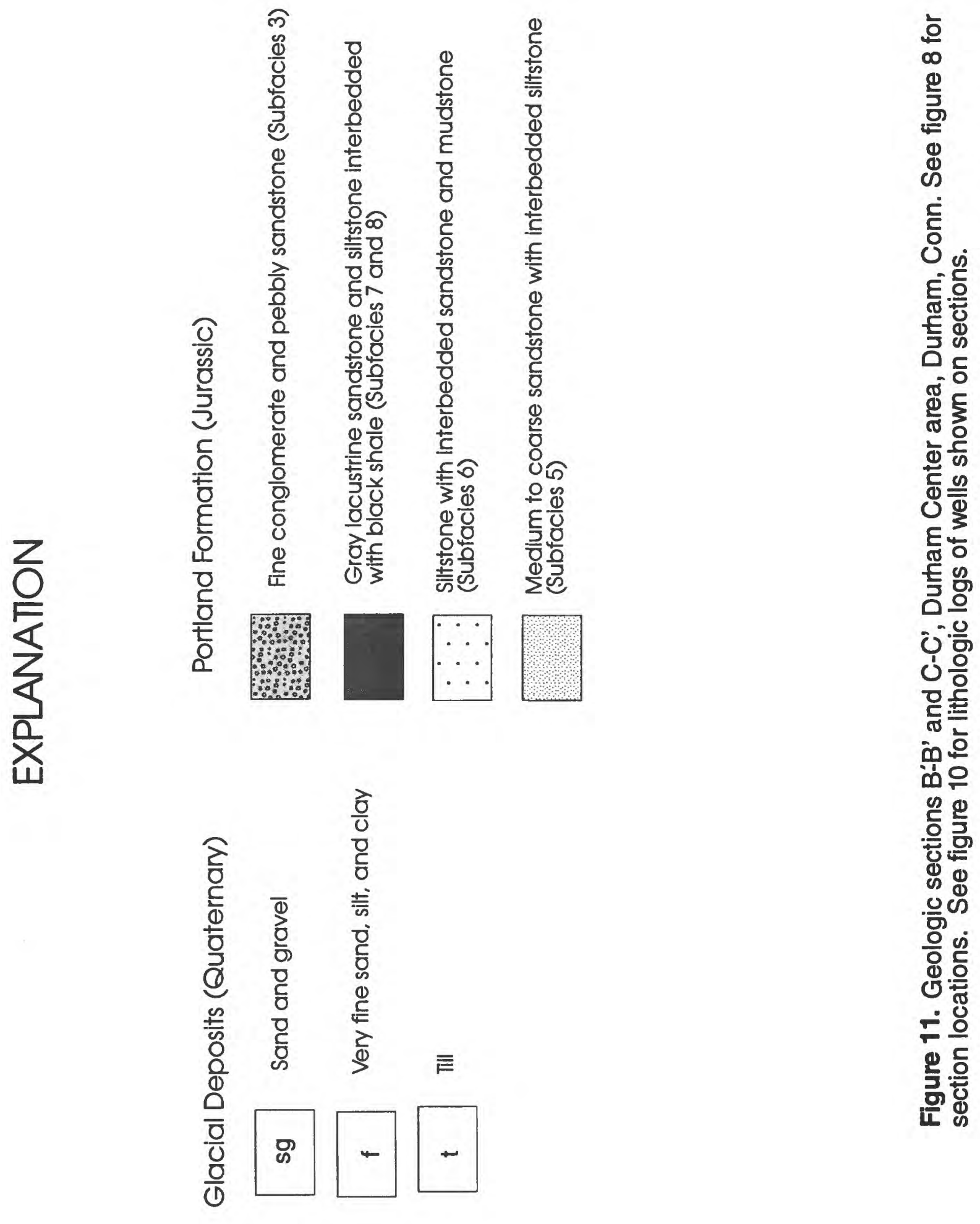


lacustrine units (subfacies 7 and 8) interlayered with coarse sandstone-pebble conglomerate units (subfacies 3 ) and red, fine-grained units that are probably siltstone (subfacies 6). The lower part of the stratigraphic section (below 150 to $200 \mathrm{ft}$ in depth), appears to be medium to coarse sandstone with siltstone interbeds (subfacies 5) and possibly zones of subfacies 4 . These units are probably related to an earlier "dry-phase" depositional environment. The lacustrine units have not been further subdivided here, but each comprises a stratigraphic sequence of subfacies 7-8-7, so that black shale is layered between gray, interbedded siltstone and sandstone. This relation has been described in outcrops (LeTourneau, 1985; Hubert, and others, 1978) and could be seen on the downhole television camera in several wells. In several places where coarse sandstone-pebble conglomerate (subfacies 3 ) overlies a lacustrine unit, clasts of black shale were recognizable within the lower few inches of the conglomerate.

The mineral composition of sediments and diagenetic cements of the Hartford Basin sandstones, including the Portland Formation, is described by Hubert and others (1992). Three sampling localities for their study were near the Durham Center area at Laurel Brook, Allyn Brook, and Arbutus Road (1.5 mi northeast of Durham Center). Portland Formation sandstones are feldspar-rich arkose and lithic arkose, composed of subequal amounts of quartz and feldspar and lesser amounts of rock fragments (mostly phyllite, slate, schist, quartzite, and gneiss). Within the feldspar fraction, the plagioclase-potassium feldspar ratio is 12:1 for fluvial sediments (derived from the Eastern Highlands) and 11:1 for lacustrine sands (derived from the Western Highlands). Grains in fluvial sediments are stained by authigenic hematite, a weathering product formed by oxidation during burial that gives the rocks their reddish color. Albite overgrowths on plagioclase-feldspar grains have lowered the porosity of these rocks; albite comprises 6 to 23 percent of the total volume of the rock. Carbonate cements consist of ferroan calcite and calcite in fluvial sandstones and ferroan dolomite and dolomite in lacustrine strata; these cements comprise 6 to 7 percent of the volume of the rock.

Locally in lacustrine units, for example at Laurel Brook, mixed-layer smectite-chlorite-corrensite is a cement, and expandable swelling chlorite is in pore fillings. Barite is also present in some lacustrine sandstones of the Portland Formation. Lacustrine black shale and mudstone typically contain 1 to 4 percent by weight of total organic carbon, whereas gray mudstones have slightly less organic carbon. The organic matter gives these lacustrine units their gray and black color.

\section{Structural geology}

Structural features of the rock units related to the movement of ground water are the strike and dip of bedding, faults, and other fractures. Beds in the Portland Formation in the Durham area strike in a generally northward direction, ranging from NNW to northeast and dip eastward at relatively low angles of $5^{\circ}$ to $10^{\circ}$ (Simpson, 1968a; LeTourneau, 1985). Direct measurement of the strike and dip of bedding at Durham Center was made during this study using the borehole logs from the Merriam Manufacturing Co. wells. Altitudes of lithologic contacts in wells D-151 and D-148 (fig. 8) are the same, indicating that these wells are along strike with each other. This defines the strike direction as approximately $\mathrm{N} 8^{\circ} \mathrm{W}$ in this area. The decrease in altitude of lithologic contacts eastward from these two wells to wells D-149 and D-150 defines the angle of dip, which is about $3^{\circ}$ to the east-northeast. The strike appears to change to a more northwesterly direction and the dip to a more northeasterly direction between the northern (B-B') and southern (C$\left.\mathrm{C}^{\prime}\right)$ geologic sections in figure 11. Stratigraphic units are about $40 \mathrm{ft}$ higher on the southern section than on the northern section, indicating a northward component of dip of about $1^{\circ}$ between the two areas. 
High-angle normal faults that clearly cut and offset linear ridges of Hampden Basalt to the west of Durham Center are shown as extending through Portland Formation rock units beneath Durham Center on the geologic map by Simpson (1968a), although they are not exposed. There is, however, strong regional evidence for at least one northeaststriking, northwest-dipping normal fault in the Portland Formation beneath Durham Center. The steep-walled valley of Ball Brook to the northeast of Durham Center is reasonably interpreted as a fault zone because of its straight, sharp trend, and because strike ridges and dip slopes in the Portland Formation have different orientations on either side of this valley. The northeast trend of Ball Brook valley can be projected southwestward across the southern end of Durham Center at the western end of the rock gorge at Allyn Brook, and then across Durham Meadows to a fault that cuts and offsets the ridge of Hampden Basalt. (See fig. 3a.) Surface- and borehole-geophysical surveys made during this study and the distribution of wells with high yields (Klimenok, 1989) also provide evidence of a fault. In this report, this fault is referred to as the Ball Brook fault.

Section C-C' (fig. 11) shows the inferred Ball Brook fault as it would appear on an eastwest section between wells D-129 and D-157 at Durham Manufacturing Co. In the upper $220 \mathrm{ft}$ of well D-129, lithologic units interpreted from borehole logs match the stratigraphy along section B-B' to the north, but cannot be correlated to the lithology at well D-157; this suggests a fault between the two wells. Well D-129 has a reported yield of $22 \mathrm{gal} / \mathrm{min}$ (table 2) and is immediately adjacent to the Durham Manufacturing Co. production well (D-212) that reportedly can yield at least 100 $\mathrm{gal} / \mathrm{min}$ (Leggette, Brashears, and Graham, Inc., 1982). Lithology changes abruptly in well D-129 at the depth of $205 \mathrm{ft}$ and gamma values increase sharply from less than 25 to more than
125 American Petroleum Institute (API) units, with a maximum value of nearly 300 API units at $211 \mathrm{ft}$. Heat-pulse flowmeter measurements show a reversal in the direction of flow within this same zone. (See appendix 1.) A similar flow reversal occurs at a depth of $195 \mathrm{ft}$, in well D-190, located southwest of well D-129 (fig. 7) along the strike of the fault. The yield of well D-190 is unknown. Well D-160, on the western side of Maple Ave., $450 \mathrm{ft}$ southwest of well D-190 (fig. 7) along the strike of the fault, is $160 \mathrm{ft}$ deep and reportedly yields 60 $\mathrm{gal} / \mathrm{min}$ (table 2). No geophysical logs were obtained at this well, but the high yield indicates that it probably intersects a major fracture zone. The wells along section B-B' to the north are not deep enough to intersect the northwest-dipping Ball Brook fault.

Square-array dc-resistivity and VLF-EM surveys conducted at site 1 , southwest of Durham Center (fig. 12), provide additional evidence of a northeast-striking, northwestdipping fault beneath this area. The data from square-array resistivity traverse $\mathrm{SQR}-1$ show a coincident low or trough in mean terrain resistivity and anisotropy values between stations 6 and 8 (fig. 13) that probably defines the approximate location of the fault. VLF-EM data along traverse line VLF-5 show a peak in the ratio of secondary to primary magnetic field near station 9 (fig. 14). This anomaly probably indicates the presence of a large fault. The azimuthal, square-array, resistivity sounding SQ-S1 made at site 1 (fig. 12) shows the primary strike direction of fractures is northeast (fig. 15); this is consistent with the presence of the Ball Brook fault. At site 2 in figure 12 (Allyn Brook Park and Regional School District 13 athletic fields east of Durham Center), VLF-EM surveys revealed no anomalies, and the azimuthal, square-array resistivity sounding indicates a primary fracture strike direction of northwest. Site 2 lies southeast of the inferred Ball Brook fault in a separate fault block. 


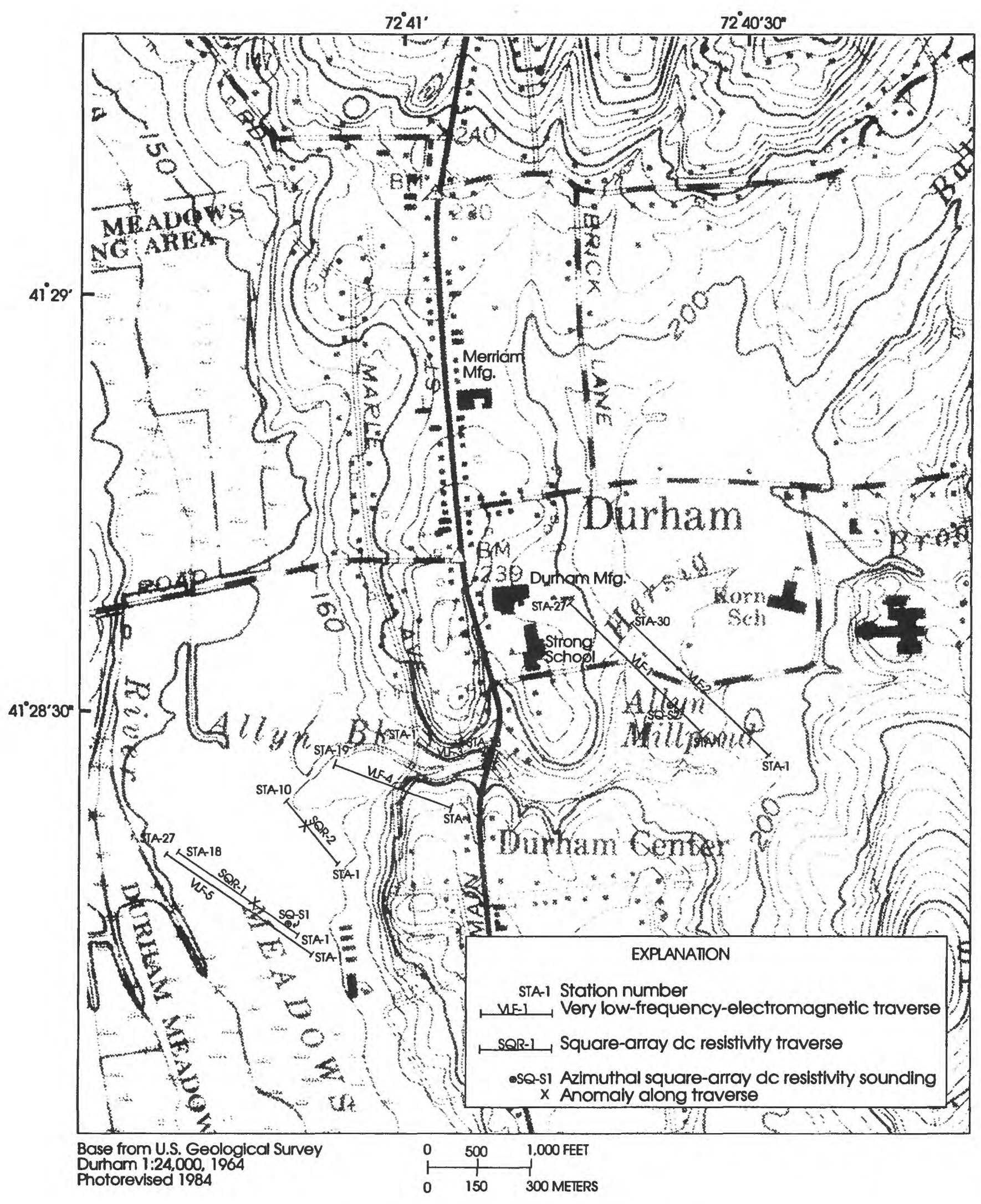

CONTOUR INIERVAL 10 FEET
NATIONAL GEODETIC VERTCAL DATUM OF 1929

Figure 12. Locations of surface-geophysical surveys in the Durham Center area, Durham, Conn. 

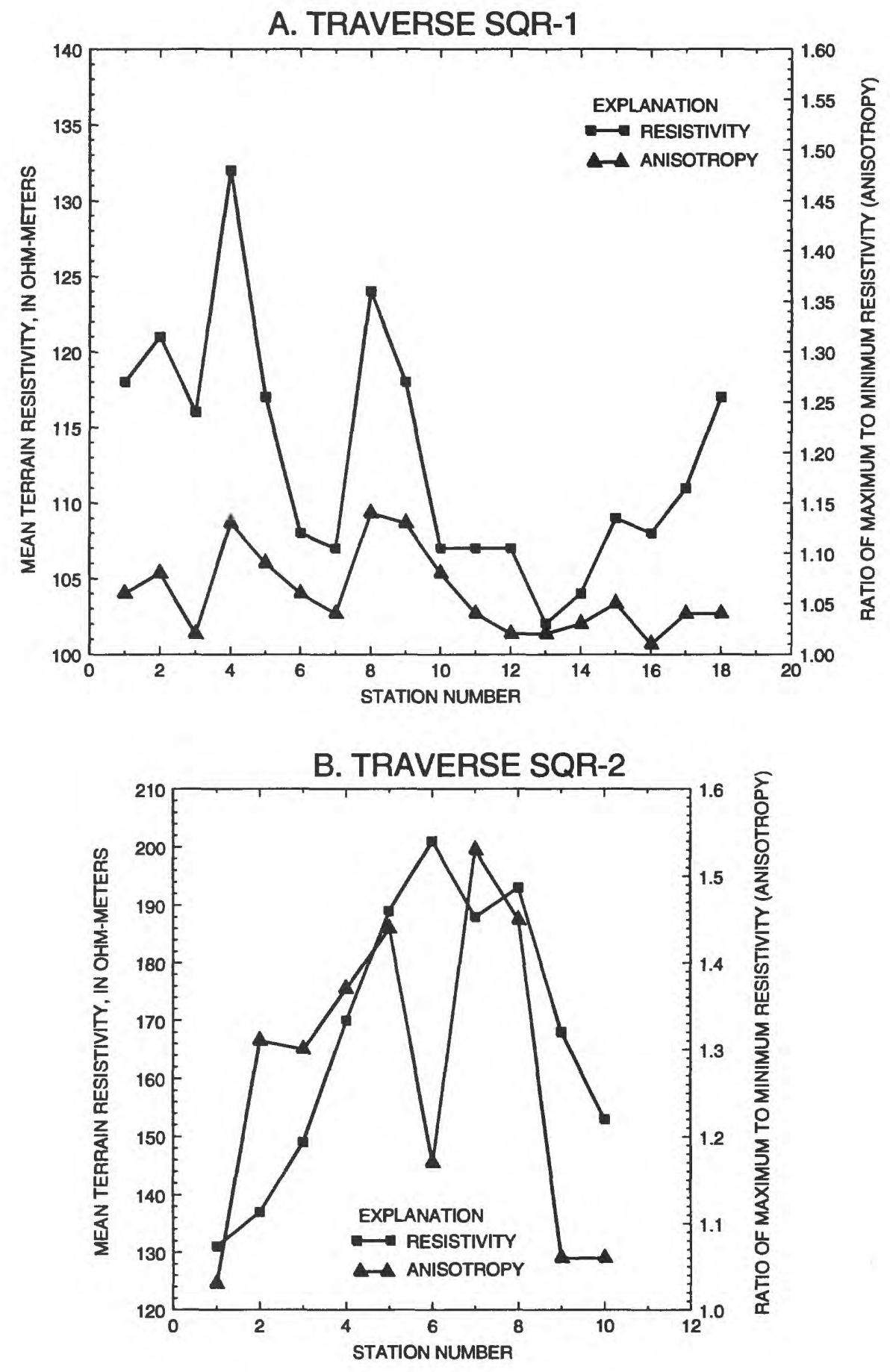

Figure 13. Mean terrain resistivity and anisotropy along square-array directcurrent resistivity traverse lines 1 and 2, Durham Center area, Durham, Conn. [Locations are shown in figure 12.] 


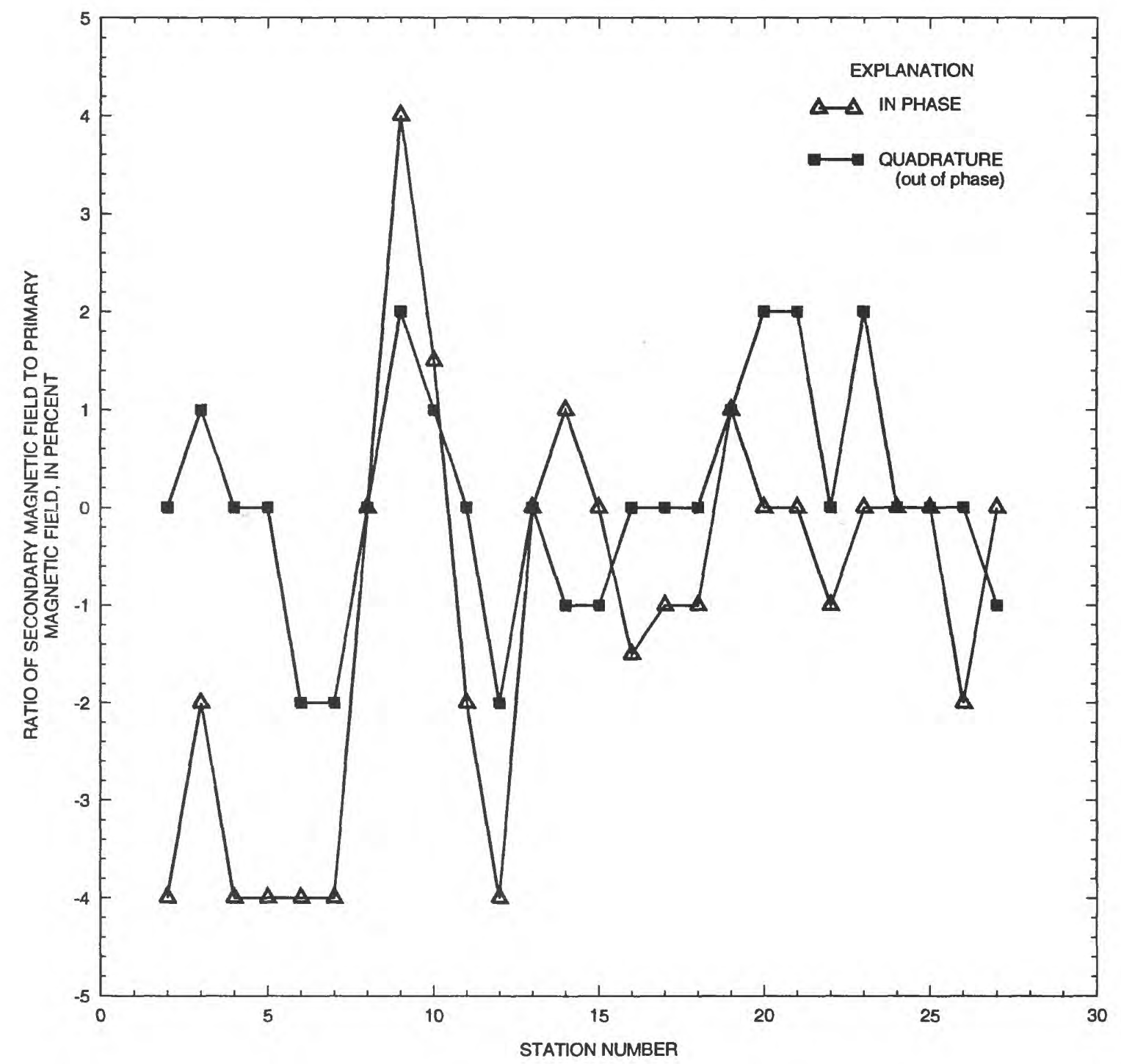

Figure 14. Ratio of secondary to primary magnetic field along very-low-frequency electromagnetic traverse line 5, Durham Center area, Durham, Conn. 


\section{SITE 1}

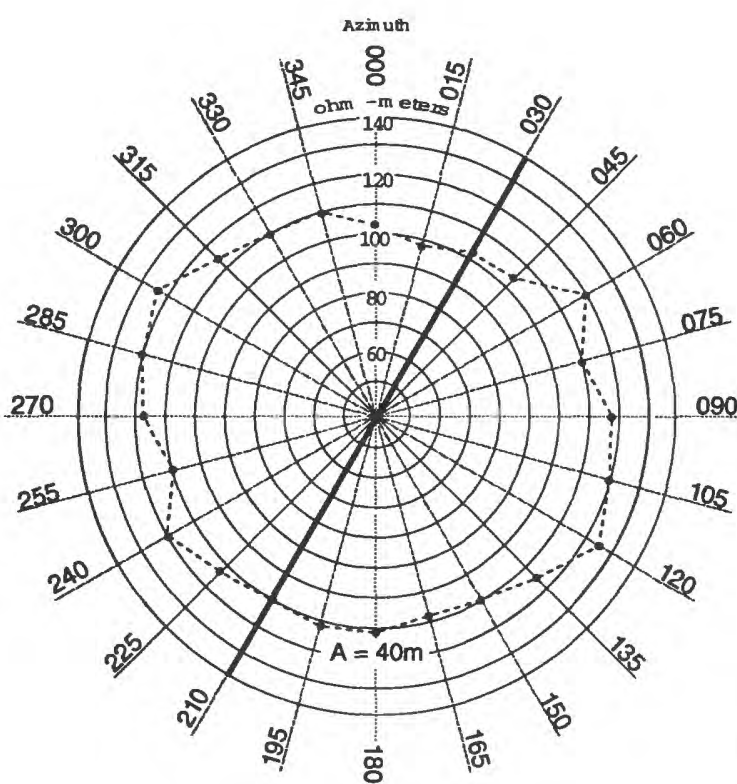

SITE 2

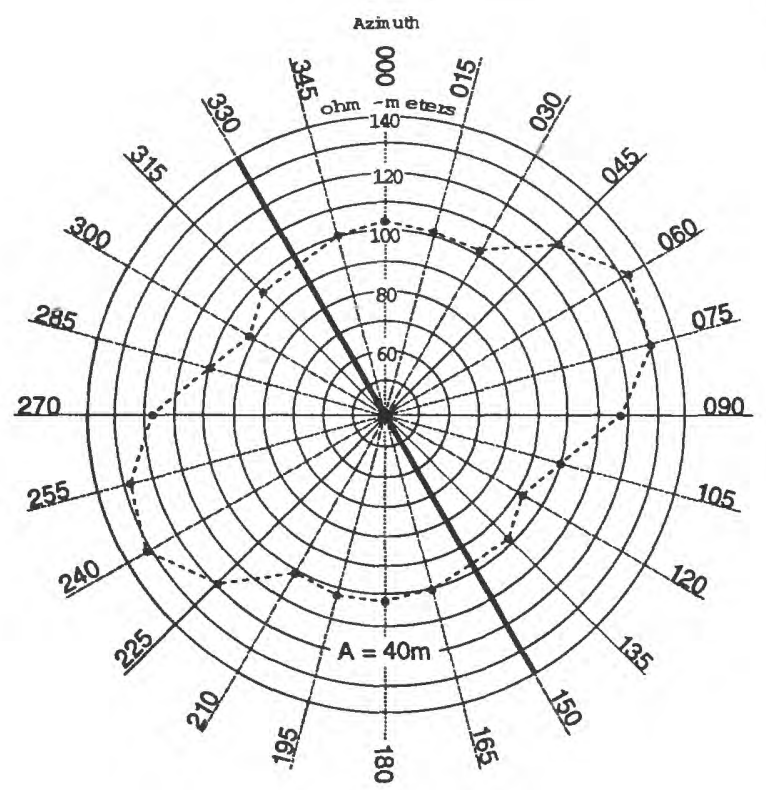

\section{EXPLANATION}

100 Line of equal apparent resistivity, in ohm - meters

- Interpreted primary fracture strike

- Data points showing apparent resistivity of bedrock at indicated azimuthal directions

000 Compass azimuth, in degrees

Figure 15. Azimuthal plots of square-array direct-current resistivity sounding measurements made with 40-meter A-spacing at sites 1 and 2, Durham Center area, Durham, Conn. 
In the northern part of the Durham Center area near Merriam Manufacturing Co., lithologic units can be correlated between wells D-78, D-151, D-148, D-149, D-150, and D-189 (fig. 10). The difficulty in correlating units between wells D-78 and D-145, which are along strike from each other and, therefore, should have lithologic-unit contacts at similar altitudes, indicates the possible presence of another fault between these two wells. Well D78 has a reported yield of $30 \mathrm{gal} / \mathrm{min}$, whereas D-145 yields only $3 \mathrm{gal} / \mathrm{min}$. More regional and site-specific data would be necessary to determine whether or not a second fault is present in this general area.

The nearest bedrock exposure at the southern boundary of Durham Center reveals a 35 -ft vertical section of WNW-dipping beds above the south bank of Allyn Brook. The Allyn Brook valley (east of Maple Avenue) occupies a possible east-trending, strike-slip fault zone (not shown in fig. 3a) and lies within a separate fault block, shown in fig. 3a. If this interpretation is correct, the strata exposed in the Allyn Brook section cannot be correlated with the stratigraphic units interpreted from the borehole logs in areas north of the inferred fault zone.

Borehole-geophysical data (appendix 1 and fig. 10) indicate relatively high-angle fractures and near-horizontal bedding-plane openings throughout the sedimentary bedrock. The fractures and bedding-plane openings that are interconnected provide the pathways for most ground-water flow in these rocks. Fracture orientations measured from acoustic-televiewer logs of wells D-151, D-148, D-149, D-150, D-189, D-190, D-129, D-157, and D-138, as well as those measured at the Allyn Brook outcrop and an outcrop along Connecticut Route 17 (1.3 mi south of Durham Center), are plotted in figure 16. Figure 16a is a contoured, lower-hemisphere, equal-area-net plot of poles normal to the fracture planes, whereas figure $16 \mathrm{~b}$ is a rose diagram showing the strike directions of fractures. Northeast-striking fractures that dip at relatively high angles to the northwest or southeast strongly predominate. Less common strike directions are to the north and east-northeast. The dominant northeast-striking fractures are undoubtedly related to normal faulting associated with the Ball Brook fault. Some fractures seen on the borehole logs are accompanied by peaks on the gamma logs. The relatively high radioactivity along northeast-trending faults and fractures that cut the Hampden Basalt was demonstrated by Simpson (1966) who was able to map their extent into the Portland Formation using a scintillometer. The high gamma peaks on the borehole logs that coincide with fractures may also be due to elevated radioactivity along fracture planes.

Figure 17 shows geoelectric sections generated using a layered-earth model of the data from square-array, resistivity soundings SQ-S1 and SQ-S2 (fig. 12). These geoelectric sections of the subsurface are consistent with geologic interpretations of well data. At both locations, the upper few feet of unconsolidated sediment consists of coarse-grained (more resistive) stratified drift (artificial fill at site 2) overlying thicker fine-grained (less resistive) glacial lacustrine deposits. Bedrock is interpreted to be 30 to $35 \mathrm{ft}$ below land surface at both sites. The higher resistivity values in the upper 15 to $20 \mathrm{ft}$ (5-6 m) of the bedrock probably represent a conglomerate unit; this coarsegrained unit overlies a less resistive, finergrained rock unit. This lithologic interpretation is supported by the borehole-geophysical logs of well D-138 (appendix 1), which is near sounding SQ-S2 (fig. 12). 

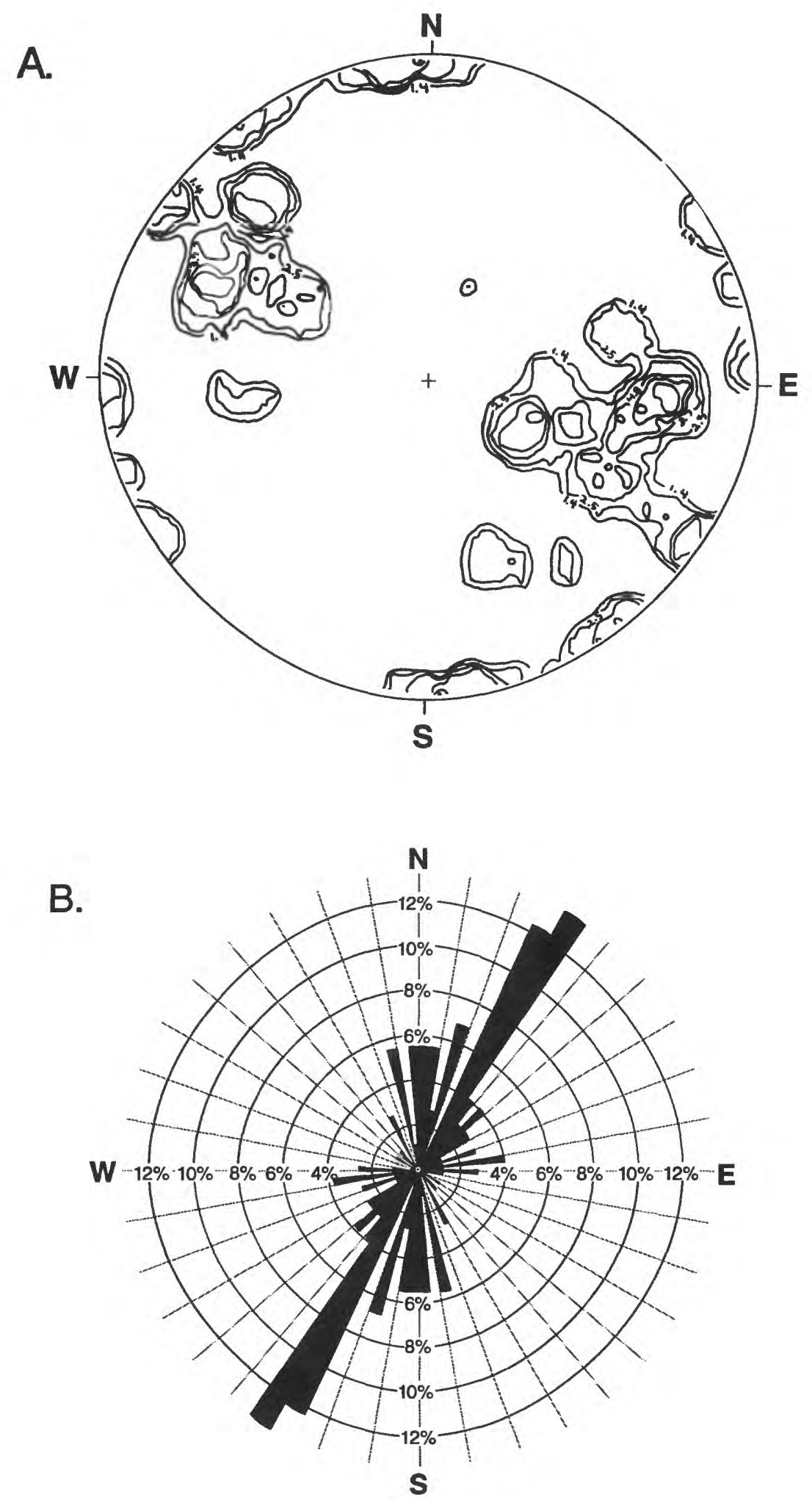

Figure 16. Lower-hemisphere, equal-area-net plot of the poles to fracture planes (a) and rose diagram showing frequency of observed strike directions of fractures (b) in the Durham Center area, Durham, Conn. 
SOUNDING SQ-S1

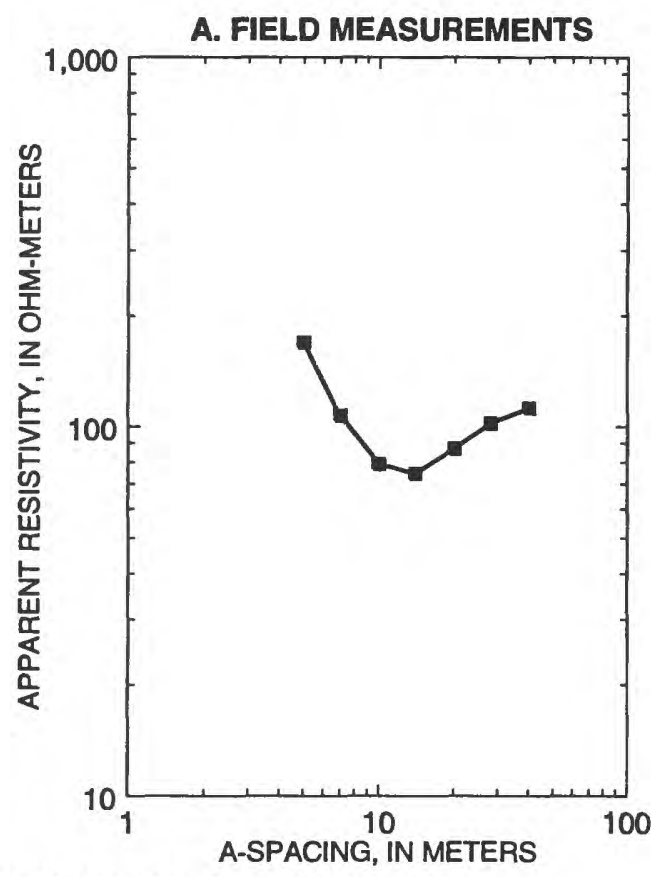

B. GEOELECTRIC SECTION FROM INVERSION OF FIELD DATA

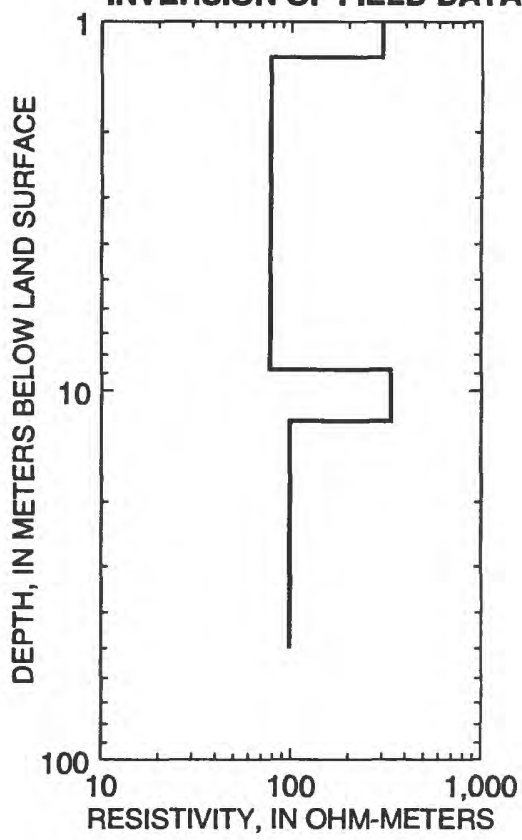

SOUNDING SQ-S2

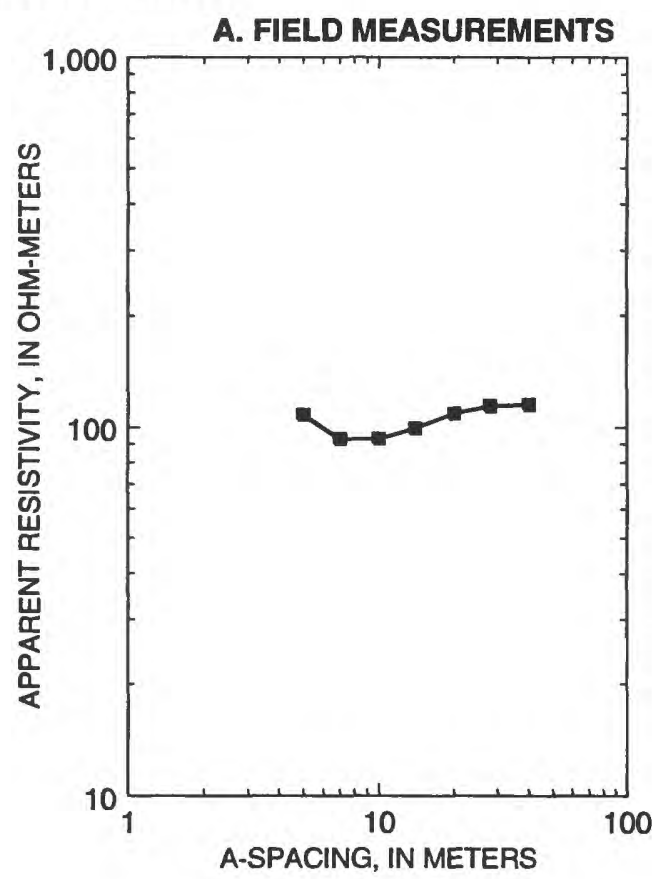

B. GEOELECTRIC SECTION FROM INVERSION OF FIELD DATA

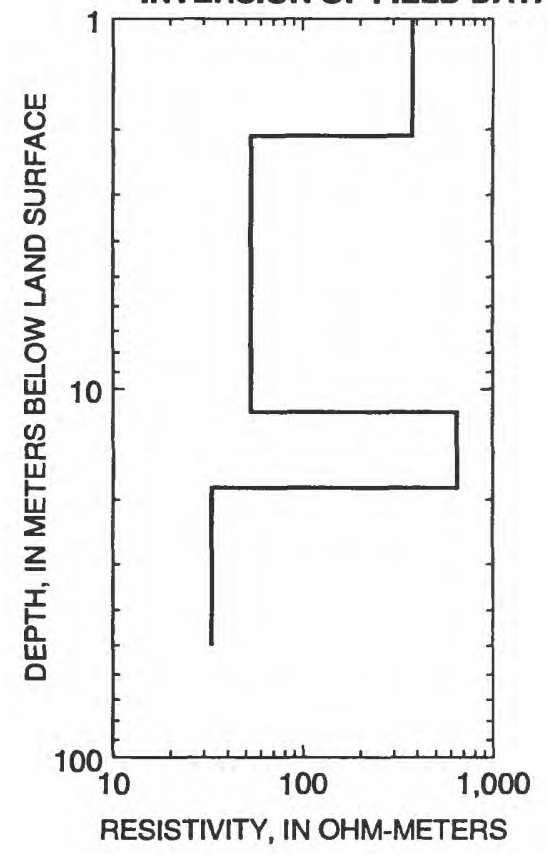

Figure 17. Apparent resistivity $(A)$ and geoelectric sections $(B)$ constructed from azimuthal, square-array direct-current resistivity soundings SQ-S1 and SQ-S2, Durham Center area, Durham, Conn. [Locations are shown in figure 12.] 


\section{Hydraulic Properties}

Aquifer tests were conducted in the Durham Center area by Leggette, Brashears, and Graham, Inc. (1982) and Roux Associates Inc. (1990a, 1990d) to estimate the transmissivity and storativity of the Portland Formation. These were constant-rate pumping tests of generally short duration (several hours); drawdown measurements were made in several wells. Pumping from other wells in the area could not be controlled during the test period and the effects of this pumping were not evaluated. The data were analyzed using the Theis nonequilibrium method (Theis, 1935) and the Jacob straight-line method (Cooper and Jacob, 1946); analytical results are summarized in table 4. Transmissivity and storativity estimates from these studies cannot be considered fully reliable for the following reasons: First, the aquifer tests were conducted under adverse field conditions--pumping throughout the area could not be controlled and drawdown measurements were commonly inadequate to define the early part of the type curve used in the Theis method of analyses. Second, the field conditions meet few of the assumptions of the analytical methods (Ferris and others, 1962; Kruseman and de Ridder, 1991). Third, the aquifer has dual permeability and porosity, the observation wells are partially penetrating, and the aquifer may actually be a series of separate aquifers--analytical methods for analyzing tests under such conditions are lacking (Bishop and others, 1993a).

Several observations made during these tests are related to the movement of ground water and dissolved contaminants. These test data, however, are not sufficient for assessing or inferring the degree of hydraulic connection between wells and areas where contaminants may possibly have entered the subsurface. The first test, conducted in 1982, used the Durham Manufacturing Co. production well (USGS well D-212) as the pumped well and measured drawdowns in accessible wells about 5 to $860 \mathrm{ft}$ away. The analysis of distance-drawdown data collected from selected observation wells after 5 hours of pumping resulted in an estimated transmissivity of about 1,600 to $1,700 \mathrm{ft}^{2} / \mathrm{d}$--the highest value reported (table 4). The relatively high transmissivity is consistent with the high yield of the pumped well (100 gal/min) and the presence of a major fault in the area that is believed to intersect the well bore. The storativity values of $6 \times 10^{-5}$ and $5 \times 10^{-4}$, determined by analyses of this test (table 4), are within the range typical of confined (artesian) aquifers.

The observation wells for this test included USGS well D-191 at Strong School, $660 \mathrm{ft}$ southeast of the pumped well (fig. 7), and an unnumbered well at 174 Main St. (Clark residence, for which there is no record) $737 \mathrm{ft}$ south of the pumped well. Water samples from these observation wells have high concentrations of organic halides (commonly greater than $1,000 \mu \mathrm{g} / \mathrm{L}$ ). The drawdowns in both wells during the aquifer test were less than $1 \mathrm{ft}$, indicating poor hydraulic connection between D-212, the pumped well, which is believed to intersect the Ball Brook fault, and these wells. However, the small drawdown in these wells may reflect complex fracture pathways that require a longer time than the 5-hour test period for a measurable hydraulic response. Much greater drawdowns were observed in other wells aligned with (1) the strike of bedding and the secondary direction of the strike of fractures $(11.57 \mathrm{ft}$ in well D$130,490 \mathrm{ft}$ to the north) and (2) the principal direction of fracturing $(9.25 \mathrm{ft}$ in well D-159, $860 \mathrm{ft}$ to the southwest).

Transmissivities calculated from aquifertest data at Merriam Manufacturing Co. (table 4) are much lower than the transmissivity derived from the test at Durham Manufacturing Co. Storativities estimated from aquifer tests at Merriam Manufacturing Co. are similar to those at Durham Manufacturing Co. and are within the range that is typical of confined aquifers. Poor hydraulic connection between wells was commonly observed, and transmissivities appeared to be directional (anisotropic) (Roux Associates Inc., 1990a and 1990d). 
Table 4. Hydraulic properties of sedimentary bedrock estimated from constant-rate aquifer tests, Durham Center area, Durham, Conn.

[USGS, U.S. Geological Survey; ft, feet]

\begin{tabular}{|c|c|c|c|c|}
\hline Location & $\begin{array}{l}\text { Type of test and } \\
\text { method of } \\
\text { analysis }\end{array}$ & $\begin{array}{c}\text { Transmissivity } \\
\text { (feet squared } \\
\text { per day) }\end{array}$ & $\begin{array}{c}\text { Storativity } \\
\text { (dimensionless) }\end{array}$ & Remarks \\
\hline $\begin{array}{l}\text { Durham } \\
\text { Manufacturing } \\
\text { Co. well } 2 \\
\text { (USGS well } \\
\text { D-212) } \\
\end{array}$ & $\begin{array}{l}\text { Theis type } \\
\text { curve (Theis, } \\
\text { 1935) and } \\
\text { distance- } \\
\text { drawdown } \\
\text { analysis using } \\
\text { Jacob's method } \\
\text { (Cooper and } \\
\text { Jacob, 1946) }\end{array}$ & 1,600 to 1,700 & $6 \times 10^{-5}$ to $5 \times 10^{-4}$ & $\begin{array}{l}\text { Analysis of } \\
\text { distance- } \\
\text { drawdown data } \\
\text { by Leggette; } \\
\text { Brashears, and } \\
\text { Graham, Inc. } \\
\text { (1982); } \\
\text { reanalyzed by } \\
\text { USGS }\end{array}$ \\
\hline $\begin{array}{l}\text { Merriam } \\
\text { Manufacturing } \\
\text { Co. well MW-2 } \\
\text { (USGS well } \\
\text { D-150) }\end{array}$ & $\begin{array}{l}\text { Theis type } \\
\text { curve (Theis, } \\
\text { 1935) and } \\
\text { straight-line } \\
\text { method (Cooper } \\
\text { and Jacob, 1946) }\end{array}$ & 51 to 62 & $\begin{array}{l}2.8 \times 10^{-4} \text { to } \\
3.7 \times 10^{-4}\end{array}$ & $\begin{array}{l}\text { Analyzed by } \\
\text { Roux } \\
\text { Associates Inc. } \\
(1990 a)\end{array}$ \\
\hline $\begin{array}{l}\text { Merriam } \\
\text { Manufacturing } \\
\text { Co. upper zone } \\
\text { (above } 150 \mathrm{ft} \text { ) of } \\
\text { well MW-1 } \\
\text { (USGS well } \\
\text { D-151) }\end{array}$ & 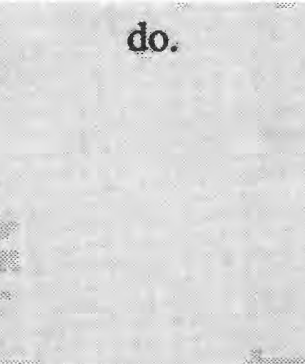 & 59 to 120 & $\begin{array}{l}3.5 \times 10^{-4} \text { to } \\
4.9 \times 10^{-4}\end{array}$ & $\begin{array}{l}\text { Analyzed by } \\
\text { Roux } \\
\text { Associates Inc. } \\
\text { (1990d) }\end{array}$ \\
\hline $\begin{array}{l}\text { Merriam } \\
\text { Manufacturing } \\
\text { Co. lower zone } \\
\text { (below } 75 \mathrm{ft} \text { ) of } \\
\text { well MW-4 } \\
\text { (USGS well } \\
\text { D-148) }\end{array}$ & do. & 50 to 270 & $\begin{array}{l}2.1 \times 10^{-4} \text { to } \\
6.4 \times 10^{-4}\end{array}$ & $\begin{array}{l}\text { Analyzed by } \\
\text { Roux } \\
\text { Associates Inc. } \\
\text { (1990d) }\end{array}$ \\
\hline
\end{tabular}

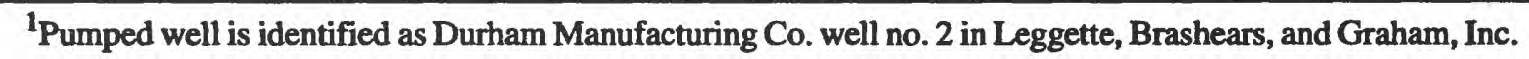
(1982) and as well no. 1 in aquifer test field notes used to record data (Robert LaMonica, Leggette, Brashears, and Graham, Inc., written commun., 1994) 
In January 1990, well MW-2 (USGS well D-150) was pumped at $2 \mathrm{gal} / \mathrm{min}$ for 7.5 hours and no drawdown was observed in nearby wells MW-1 and MW-3 (USGS wells D-151 and D-189) (Roux Associates Inc., 1990a). Time-drawdown data from the third observation well, MW-5 (USGS well D-149) $170 \mathrm{ft}$ from the pumped well, were used to calculate the transmissivity and storativity listed in table 4.

Aquifer tests in which a packer was used to isolate upper and lower zones of wells were also conducted at Merriam Manufacturing Co. in 1990 (Roux Associates Inc., 1990d). In one such test, the zone above a depth of $150 \mathrm{ft}$ in well MW-1 (USGS well D-151) was pumped at a rate of $2.5 \mathrm{gal} / \mathrm{min}$ for 22 hours. Little drawdown was measured in nearby observation wells MW-2, MW-3, and MW- 5 but no drawdown was measured in the nearest well MW-4 (USGS well D-148). Finally, water was pumped from the lower zone of well MW-4 (below $75 \mathrm{ft}$ ) at a rate of $4 \mathrm{gal} / \mathrm{min}$ for 20 hours. The drawdown in the lower zone at the end of the test was $59 \mathrm{ft}$, whereas no drawdown occurred in the isolated upper zone. Despite the poor hydraulic connection between wells and even between zones in the same well, no significant differences in groundwater quality were found in samples collected during this test (Roux Associates Inc., 1990d).

Transmissivity was estimated by USGS from the specific capacity of 55 wells in this area for which yield and drawdown data are available. Most of these wells were 6-in. diameter domestic wells that had been pumped for about 4 hours. Transmissivities that would result from specific capacities of about 0.01 , 0.1 , and $1.0 \mathrm{gal} / \mathrm{min} / \mathrm{ft}$ were calculated using the following formula developed by Theis for a 100-percent-efficient well (1963), and modified for artesian conditions by Brown (1963):

$$
\frac{Q}{s}=\frac{T}{264 \log _{10}\left(\frac{T t}{1.87\left(r_{w}\right)^{2} S}\right)-65.5},
$$

where $Q$ is the well yield in $\mathrm{gal} / \mathrm{min}, s$ is the drawdown in $\mathrm{ft}, T$ is the transmissivity expressed in $\mathrm{gal} / \mathrm{d} / \mathrm{ft}, S$ is the storativity (dimensionless and assumed to be $5 \times 10^{-4}$ ), $t$ is the pumping period in days, and $r_{w}$ is the effective well radius in $\mathrm{ft}$. Transmissivity was converted to $\mathrm{ft}^{2} / \mathrm{d}$ by dividing by 7.48 --the number of gallons in $1 \mathrm{ft}^{3}$ of water.

Results of these computations and specific capacity data from the 55 wells show that the estimated transmissivities are less than $1.5 \mathrm{ft}^{2} / \mathrm{d}$ at 9 percent of the sites; are 1.5 to $20 \mathrm{ft}^{2} / \mathrm{d}$ at 75 percent of the sites; and are 21 to $277 \mathrm{ft}^{2} / \mathrm{d}$ at 14.5 percent of the sites. At one site (USGS well D-178) representing the remaining 1.8 percent of the sample population, the estimated transmissivity is about $800 \mathrm{ft}^{2} / \mathrm{d}$.

Neither the intergranular porosity nor fracture porosity of the bedrock beneath Durham Center has been measured. A test performed on a sample of sandstone collected from the Portland Formation at Portland, Conn. showed the intergranular porosity to be approximately 7 percent (Gregory, 1909, p. 105). Total porosities of samples of sedimentary rocks from the New Haven Formation reported by Haeni and Anderson (1980) range from 2.9 to 11.1 percent. A median intergranular porosity of 5 or 6 percent is a reasonable estimate for sandstones and siltstones at Durham Center. The secondary porosity due to fracturing was estimated from the square-array dc-resistivity soundings using the method described by Lane and others (1995). The estimates of secondary porosity of 1.1 and 2.7 percent made by this method assume no clay or mineralization in the fractures and that the anisotropy is entirely due to fractures. An estimate of fracture porosity for similar fractured sedimentary rocks in Coventry, England, was less than 1 percent (Lerner and others, 1993a) and the estimates derived from analyses of the square-array resistivity data may be too high. On the other hand, the resistivity soundings were made in areas where a fault or fault zone 
is believed to be present and higher fracture porosity would be likely.

\section{Hydrologic Models for the Bedrock}

Two basic hydrologic models have been used to describe sedimentary bedrock aquifers such as underlie the Durham Center area (Michalski, 1990). The first model depicts the rocks as part of a single aquifer with horizontal to vertical anisotropy. An unconfined zone extends to depths of at least $250 \mathrm{ft}$, below which the conditions may be locally confined or semi-confined (leaky). Near-vertical fractures provide the principal pathways for ground water in this single aquifer model. In the second model, all the saturated bedrock is part of a multi-zone (or leaky multi-unit) aquifer system. No regional aquifers and confining units are identifiable in this system. The water-bearing zones could be large openings along bedding planes or layers of densely fractured rock; widely spaced, highangle fractures, would provide pathways for leakage between these zones. These models represent two extremes and any intermediate combination of the two is possible.

The regional and local geohydrologic information is ambiguous and inadequate to resolve which hydrologic model or combination of models best describes the conditions in the Durham Center area. Geologic field observations at the regional scale tend to support the presence of a stratigraphically controlled multi-unit aquifer system. Gregory (1909) and Klimenok (1989) have noted contrasts in the degree of fracturing that are related to lithology and differences in well yields that also appear to be related to the lithology of the sedimentary rocks. Detailed examination of large quarry exposures of the Portland Formation at Portland, Conn., about 8 mi from Durham, showed preferential flow of water in open bedding planes, especially along shaly partings and at the contact between strata of varying texture and composition (Gregory, 1909 , p.108). However, significant flow of water (about $0.25 \mathrm{Mgal} / \mathrm{d}$ ) from vertical joints was also observed by Gregory (1909) at the Portland quarries. Bedding planes and geologic contacts between basalts and sedimentary rocks were identified as the most important conduits for ground-water flow in Durham by Klimenok (1989), although no specific field evidence was presented.

Klimenok (1989) also observed that a relation existed between high well yields and steeply dipping faults in the Durham Center area and elsewhere in Durham.

Interpretations of the borehole-geophysical logs in appendix 1 show many zones where inflow or outflow of water are associated with high-angle fractures depicted in figure 10 , as well as similar zones of inflow or outflow of water apparently unrelated to this type of fracture. For example, in USGS well D-190, a large reduction in the upward ambient flow from almost $0.3 \mathrm{gal} / \mathrm{min}$ to about $0.02 \mathrm{gal} / \mathrm{min}$ is found in the depth interval between 114 and $126 \mathrm{ft}$ (appendix 1). Within this interval, the caliper and focused resistivity logs indicate a major open space, and the acoustic televiewer $\log$ interpretation is that the opening is a steeply dipping fracture (fig. 10). In this same well, downward flow of about $0.1 \mathrm{gal} / \mathrm{min}$ was found below $200 \mathrm{ft}$, but no fracture is apparent through which the water leaves the well bore. An increase in upward flow of $0.23 \mathrm{gal} / \mathrm{min}$ was measured between depths of $277.5 \mathrm{ft}$ and $260 \mathrm{ft}$ in well D-129 and a large change in fluid resistivity was measured in the same depth interval (appendix 1). The acoustic televiewer log does not show any high-angle fractures, but a nearly horizontal bedding plane opening at a depth of $266 \mathrm{ft}$ is the likely zone where water enters the well. Additional examples of the association, or lack of association, between ambient flow in wells and steeply dipping fractures can be seen in other wells where heatpulse flowmeter measurements and acoustic televiewer logs are available.

Two of the older bedrock wells in Durham Center, D-46 and D-48 (table 2 and fig. 7), reportedly flowed at the time they were constructed, although they were completed at 
relatively shallow depths of $135 \mathrm{ft}$ and $125 \mathrm{ft}$, respectively. Shallow flowing wells are consistent with the second (multi-unit) aquifer model but not the first (single-aquifer) model in which there is an extensive unconfined zone. Water levels in more recently drilled bedrock wells commonly exceed $20 \mathrm{ft}$ below land surface (table 2) but water levels in these younger wells are likely affected by pumping from the other nearby bedrock wells.

Other indicators of a multi-unit artesian or leaky aquifer system are variations in hydraulic head in nearby wells of similar depth and high vertical hydraulic gradients induced by layers of low permeability (Michalski, 1990; Bishop and others, 1993a). Water-level measurements for 13 bedrock wells made by Roux Associates Inc. on January 15, 1990 (Roux Associates Inc., 1990a), are shown in figure 18. This figure shows that water levels in nearby wells can differ by several feet, even when well depths are approximately the same. Another set of water-level measurements made by Leggette, Brashears, and Graham, Inc. (1982) on August 26, 1982, shows similar variability. At the time both sets of measurements were made, however, pumpage of nearby wells was not controlled, and observed differences in water levels could be ascribed to differences in cumulative drawdowns resulting from pumpage throughout the area. Likewise, differences in water levels can result if nearby wells do not tap the same high-angle, wateryielding fracture. High vertical hydraulic gradients have been measured at Merriam Manufacturing Co. where packers were used to isolate upper and lower zones in two bedrock wells. A head difference of almost $34 \mathrm{ft}$ was reported (Roux Associates Inc., 1990d, appendix B) after a packer was installed at a depth of $150 \mathrm{ft}$ to isolate the upper and lower zones in well MW-1 (USGS well D-151). The observed head difference could indicate the presence of a multi-unit artesian or leaky aquifer system or, alternatively, result from the local subsurface distribution of steeply dipping fractures. Although cited as evidence of a single or multi-unit aquifer system, an anisotropic response to pumping, as was observed during the aquifer test at Durham Manufacturing Co. (Leggette, Brashears, and Graham, Inc., 1982), can occur in either system (Michalski, 1990).

The sparse and commonly ambiguous information that has been described to date indicates that bedrock geohydrologic conditions at Durham Center are a hybrid, resembling the single aquifer model in some aspects but also having many features of the multi-unit aquifer model. Furthermore, the high concentrations of organic halides are present not only southwest of purported source areas--a direction that coincides with the primary orientation of the strike of most steeply dipping fractures and a large fault--but also along a generally north to south axis which coincides with the strike of less common fractures, and the local strike direction of the sedimentary rocks. More data on horizontal and vertical head distribution, particularly under nonpumping conditions, and the relative flow along bedding plane openings or fractured beds and dipping fractures would enable better definition of the nature of the bedrock aquifer or aquifers.

\section{Ground-Water Flow}

A local ground-water flow system has developed in response to the topographic relief and moderate recharge. This system is unconfined and includes saturated till and at least the upper part of the saturated bedrock. Recharge to this system occurs in the topographically high areas, and discharge is to adjacent streams and wetlands, as shown in figure 6 . The configuration of the water table is likely similar to the land surface, but has only been defined by measurements at Durham Manufacturing Co. (Leggette, Brashears, and Graham, Inc., 1982) and Merriam Manufacturing Co. (Roux Associates Inc., 1990a). Measurements of the water-table altitude on August 5, 1982, made by Leggette, Brashears, and Graham, Inc. (1982) show that the horizontal direction of ground-water flow was eastward from the Durham Manufacturing Co. plant toward Ball Brook. The water-table gradient was about 
0.026 (Leggette, Brashears, and Graham, Inc., 1982, fig. 6). Measurements of water levels in four wells (USGS wells D-200 to 203) east of Merriam Manufacturing Co. made on November 13, 1989 (Roux Associates Inc., 1990a), indicate that the horizontal ground-water flow at that time was to the southeast. The water table in till also fluctuates several feet a year, as shown by the hydrograph of the nearby USGS observation well D-117 (fig. 9), and over longer periods, fluctuations of more than $16 \mathrm{ft}$ have been observed in till wells elsewhere in Connecticut (Melvin and others, $1992 \mathrm{~b}$, p. 25). The water-table altitudes and hydraulic gradients at these two manufacturing locations consequently can be expected to differ from those observed in August 1982 and November 1989.

The withdrawal of water from the bedrock that underlies the till is likely to have resulted in significant vertical flow within the local ground-water-flow system. High vertical hydraulic gradients, even as high as $1: 1$, could result if pumpage from bedrock wells produces large drawdown in areas where the saturated till and bedrock are hydraulically well connected. The high vertical gradients would induce vertical downward flow through the till that could exceed the horizontal flow. No head measurements in the area are adequate for defining vertical ground-water flow in the local flow system.

A larger intermediate- or regional-scale flow system is believed to be present at some depth in the saturated bedrock, as evidenced by the presence of moderate to high concentrations of organic chemicals in ground water west and southwest of the drainage divide that separates Allyn Brook from Ball Brook (Metcalf and Eddy, 1994). The water-level measurements from wells cannot be used, even to define the horizontal direction of ground-water movement within this system, because of the effects of cyclical pumping and vertical components of flow. It is also likely that any largescale flow is controlled by high-permeability zones created by fractures and openings along bedding planes.
Evidence also indicates that the many bedrock wells drilled in this area have altered the ground-water-flow system by connecting zones that were hydraulically isolated under natural conditions. The existence of vertical hydraulic gradients in bedrock wells (Roux Associates Inc., 1990d) and anomalies in fluidtemperature gradients, variations in fluid resistivity, and heat-pulse flowmeter measurements (appendix 1) all indicate that there is considerable circulation of water in at least some well bores under ambient (nonpumping) conditions. Vertical circulation of fluid in wells under pumping conditions may even be greater than indicated by the borehole logs.

\section{Streamflow}

Ball Brook and two of its unnamed tributaries drain land on which Durham Manufacturing Co. and Merriam Manufacturing Co. are located (fig. 6) and receive ground-water runoff from the local ground-water flow system. Wastewater discharges to these streams were reported by DOHS in 1970 (G. G. Bonadies, Connecticut Dept. of Health Services, written commun., 1970) and organic halides were detected in Ball Brook in 1982 (Leggette, Brashears, and Graham, Inc., 1982). Information on the flow of Ball Brook and other streams in the Allyn Brook basin is therefore important for assessing water quality. Apparently no streamflow data were collected in the previous studies and no prior discharge measurements of any streams in the Allyn Brook basin had been made by the USGS. Continuous records of the flow of the Coginchaug River at downstream USGS stations in Middlefield, Conn., (stations 011928.90 and 011928.83) are available from October 1961 to the present (1994) and records of daily discharge have been published in the annual series of USGS data reports titled "Water Resources Data for Connecticut." Streamflow in the Coginchaug River basin may be affected by infrequent releases from a recreational lake and diversions for agriculture, recreation, and water supply. 


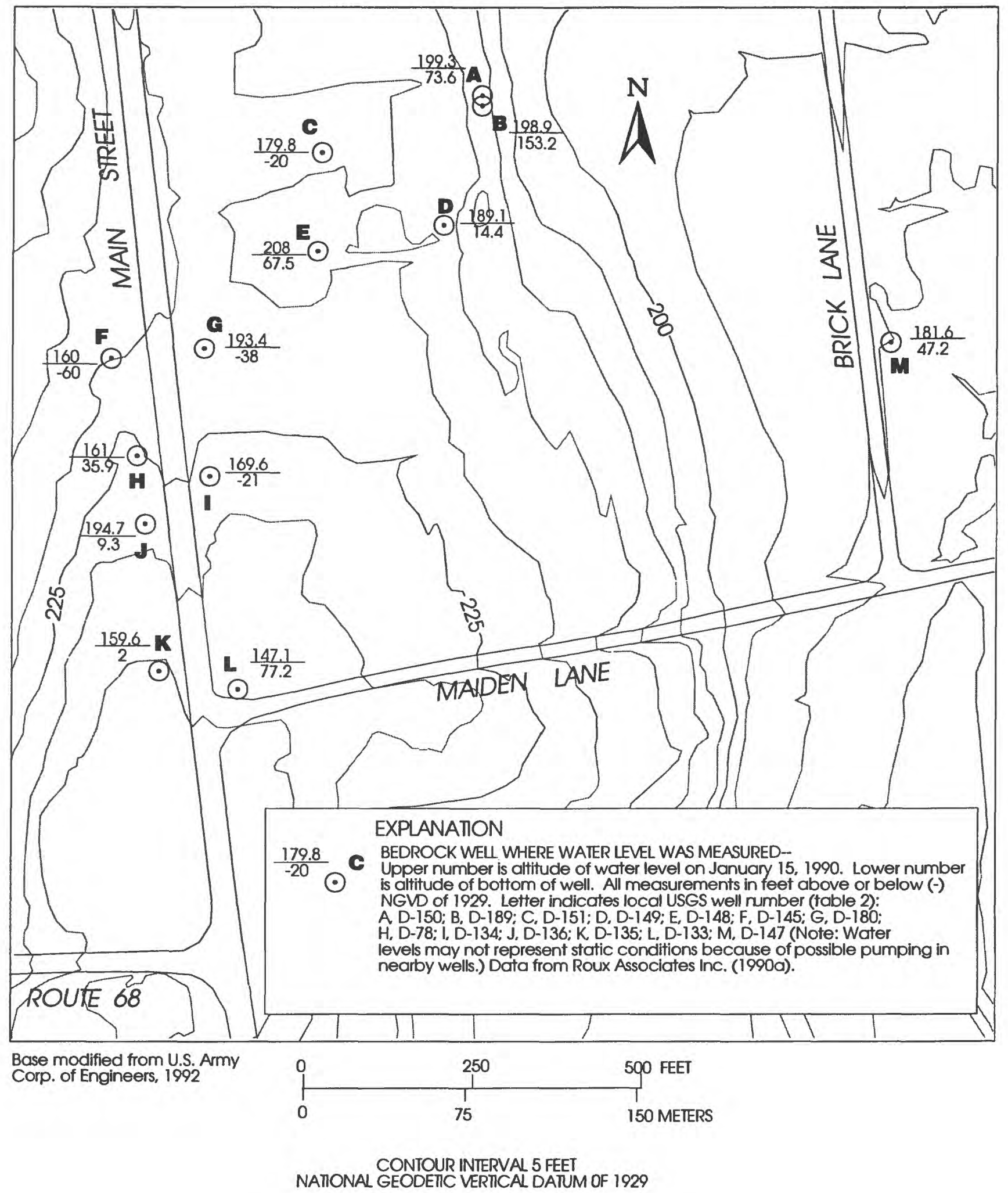

Figure 18. Water levels in bedrock wells in the northem part of the Durham Center area, Durham, Conn., on January 15, 1990. 
Five partial-record streamgaging stations, identified in table 5 and located in figure 19, were established in April 1993 to provide data on low-flow characteristics and to support planned water-quality sampling by USEPA. Discharge measurements that were made at these stations between April 23, 1993 and September 22, 1993 are listed in table 5; rating curves developed from these measurements are shown in figure 20. Flow-duration estimates for the various discharge measurements were made by constructing a flow-duration curve for the continuous record station on the Coginchaug River (station 011928.83) and then correlating the discharges at each partialrecord station (other than station 011928.12) with the daily discharge at the Coginchaug station. The estimated flow durations assigned to the discharge measurements at the partialrecord sites (table 5) may not be equivalent to long-term flow durations because of the relatively short record (1982-90) used to determine flow durations at station 011928.83. Flow durations could not be estimated for dis- charge measurements at the partial-record station on one of the tributaries to Ball Brook (station 011928.12) because of the poor correlation with daily discharges of the Coginchaug River.

Selected flow characteristics of streams in the Allyn Brook watershed can be roughly estimated by regionalization techniques. As an example, estimates of selected flow durations can be developed from regional flow-duration curves (Thomas, 1966). The 7-day, 10-year low flow at this or other locations can also be estimated from a regional formula developed by regression analyses (Cervione and others, 1982). It should be noted that the regionalization techniques for estimating flow duration and low-flow frequency apply only to unregulated streams and are based on the reference period October 1, 1930 through September 30, 1960 for flow duration, and the reference period April 1, 1941 through March 31, 1971 for the 7-day, 10-year low flow. 


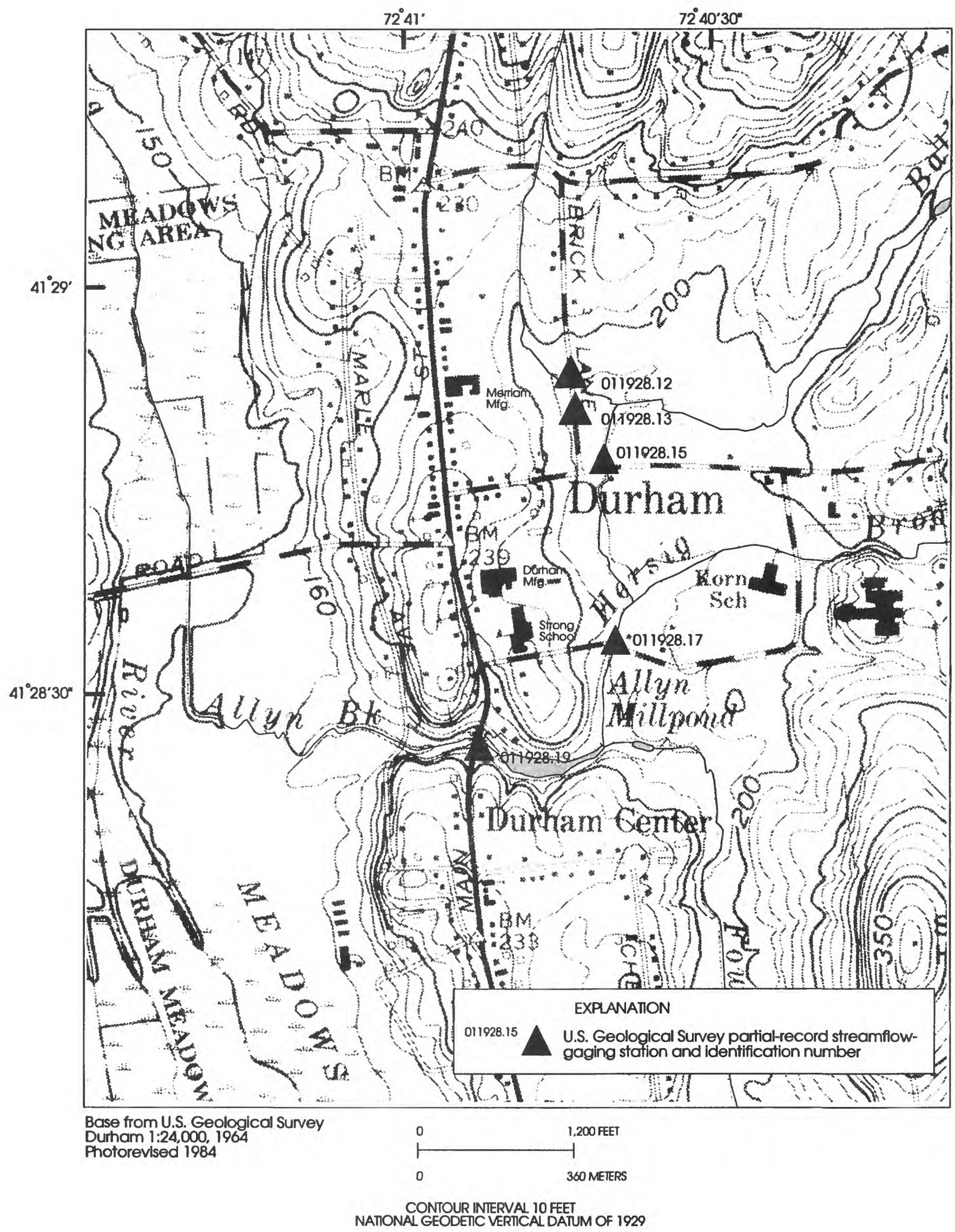

Figure 19. Locations of U.S. Geological Survey partial-record streamflow-gaging stations in the Allyn Brook drainage basin, Durham, Conn. 
Table 5. Discharge measurements and flow-duration estimates for Allyn Brook and selected tributaries in Durham, Conn., in 1993

[Locations shown in fig. 19; D.A., drainage area; $\mathrm{mi}^{2}$, square mile; --, not estimated]

\begin{tabular}{|c|c|c|c|c|}
\hline $\begin{array}{c}\text { Name, } \\
\text { location, and } \\
\text { drainage area of } \\
\text { measurement site } \\
\text { (square miles) }\end{array}$ & $\begin{array}{c}\text { U.S. } \\
\text { Geological } \\
\text { Survey } \\
\text { station } \\
\text { number }\end{array}$ & Date & $\begin{array}{l}\text { Discharge, in } \\
\text { cubic feet per } \\
\text { second }\end{array}$ & $\begin{array}{l}\text { Estimated } \\
\text { flow duration, } \\
\text { in percent }\end{array}$ \\
\hline \multirow{11}{*}{$\begin{array}{l}\text { Tributary to Ball } \\
\text { Brook (northern) at } \\
\text { Brick Lane } \\
\text { D.A. }=0.01 \mathrm{mi}^{2}\end{array}$} & \multirow[t]{11}{*}{011928.12} & April 23, 1993 & 0.46 & - \\
\hline & & May 7, 1993 & .22 & - \\
\hline & & May 25, 1993 & .01 & -- \\
\hline & & June 9, 1993 & .02 & - \\
\hline & & June 17,1993 & .02 & -- \\
\hline & & July 22,1993 & .00 & -- \\
\hline & & Aug. 6, 1993 & .00 & - \\
\hline & & Aug. 13, 1993 & .00 & - \\
\hline & & Aug. 26, 1993 & .00 & -- \\
\hline & & Sept. 22, 1993 & .07 & -- \\
\hline & & Sept. 22,1993 & .05 & -- \\
\hline \multirow{10}{*}{$\begin{array}{l}\text { Tributary to Ball } \\
\text { Brook (southern) } \\
\text { at Brick Lane } \\
\text { D.A. }=0.28 \mathrm{mi}^{2}\end{array}$} & \multirow[t]{10}{*}{011928.13} & April 23, 1993 & 0.55 & 11 \\
\hline & & May 7, 1993 & .34 & 26 \\
\hline & & May 25,1993 & .16 & 62 \\
\hline & & June 9, 1993 & .10 & 77 \\
\hline & & June 17, 1993 & .04 & 91 \\
\hline & & July 22, 1993 & .01 & 100 \\
\hline & & Aug. 6, 1993 & .00 & 100 \\
\hline & & Aug. 13, 1993 & .00 & 100 \\
\hline & & Aug. 26, 1993 & .01 & 96 \\
\hline & & Sept. 22, 1993 & .17 & 59 \\
\hline \multirow{9}{*}{$\begin{array}{l}\text { Ball Brook at } \\
\text { Maiden Lane } \\
\text { D.A. =1.6 mi }\end{array}$} & \multirow[t]{9}{*}{011928.15} & April 23, 1993 & 6.9 & 11 \\
\hline & & May 7, 1993 & 3.2 & 28 \\
\hline & & May 25, 1993 & 1.1 & 68 \\
\hline & & June 9,1993 & .73 & 77 \\
\hline & & June 17,1993 & .39 & 86 \\
\hline & & Aug. 6, 1993 & 311 & 97 \\
\hline & & Aug. 13, 1993 & .10 & 97 \\
\hline & & Aug. 26, 1993 & .20 & 92 \\
\hline & & Sept. 22, 1993 & 1.3 & 64 \\
\hline
\end{tabular}


Table 5. Discharge measurements and flow-duration estimates for Allyn Brook and selected tributaries in Durham, Conn., in 1993--continued

[Locations shown in fig. 19; D.A., drainage area; $\mathrm{mi}^{2}$, square mile; --, not estimated]

\begin{tabular}{|c|c|c|c|c|}
\hline $\begin{array}{c}\text { Name, } \\
\text { location, and } \\
\text { drainage area of } \\
\text { measurement site } \\
\text { (square miles) }\end{array}$ & $\begin{array}{c}\text { U.S. } \\
\text { Geological } \\
\text { Survey } \\
\text { station } \\
\text { number }\end{array}$ & Date & $\begin{array}{l}\text { Discharge, in } \\
\text { cubic feet per } \\
\text { second }\end{array}$ & $\begin{array}{c}\text { Estimated } \\
\text { flow duration, } \\
\text { in percent }\end{array}$ \\
\hline \multirow{11}{*}{$\begin{array}{l}\text { Hersig Brook at } \\
\text { Allyn Brook Park } \\
\text { D.A. }=3.8 \mathrm{mi}^{2}\end{array}$} & \multirow[t]{11}{*}{011928.17} & April 23. 1993 & 19 & 11 \\
\hline & & May 7, 1993 & 9.3 & 31 \\
\hline & & May 25,1993 & 3.1 & 70 \\
\hline & & June 9,1993 & 2.2 & 77 \\
\hline & & June 17, 1993 & 1.3 & 85 \\
\hline & & July 17,1993 & .65 & 92 \\
\hline & & July 22,1993 & .31 & 98 \\
\hline & & Aug. 6, 1993 & .28 & 99 \\
\hline & & Aug. 13, 1993 & .29 & 99 \\
\hline & & Aug. 26,1993 & .59 & 93 \\
\hline & & Sept. 22, 1993 & 3.0 & 71 \\
\hline \multirow{9}{*}{$\begin{array}{l}\text { Allyn Brook below } \\
\text { Route } 17 \\
\text { D.A. }=5.1 \mathrm{mi}^{2}\end{array}$} & \multirow[t]{9}{*}{011928.19} & April 23, 1993 & 22 & 11 \\
\hline & & May 7, 1993 & 9.6 & 33 \\
\hline & & May 25, 1993 & 3.9 & 70 \\
\hline & & June 9, 1993 & 2.9 & 76 \\
\hline & & June 17, 1993 & 1.5 & 87 \\
\hline & & July 22, 1993 & .42 & 98 \\
\hline & & Aug. 6, 1993 & .27 & 99 \\
\hline & & Aug. 13, 1993 & .31 & 99 \\
\hline & & Aug. 26, 1993 & .67 & 95 \\
\hline
\end{tabular}



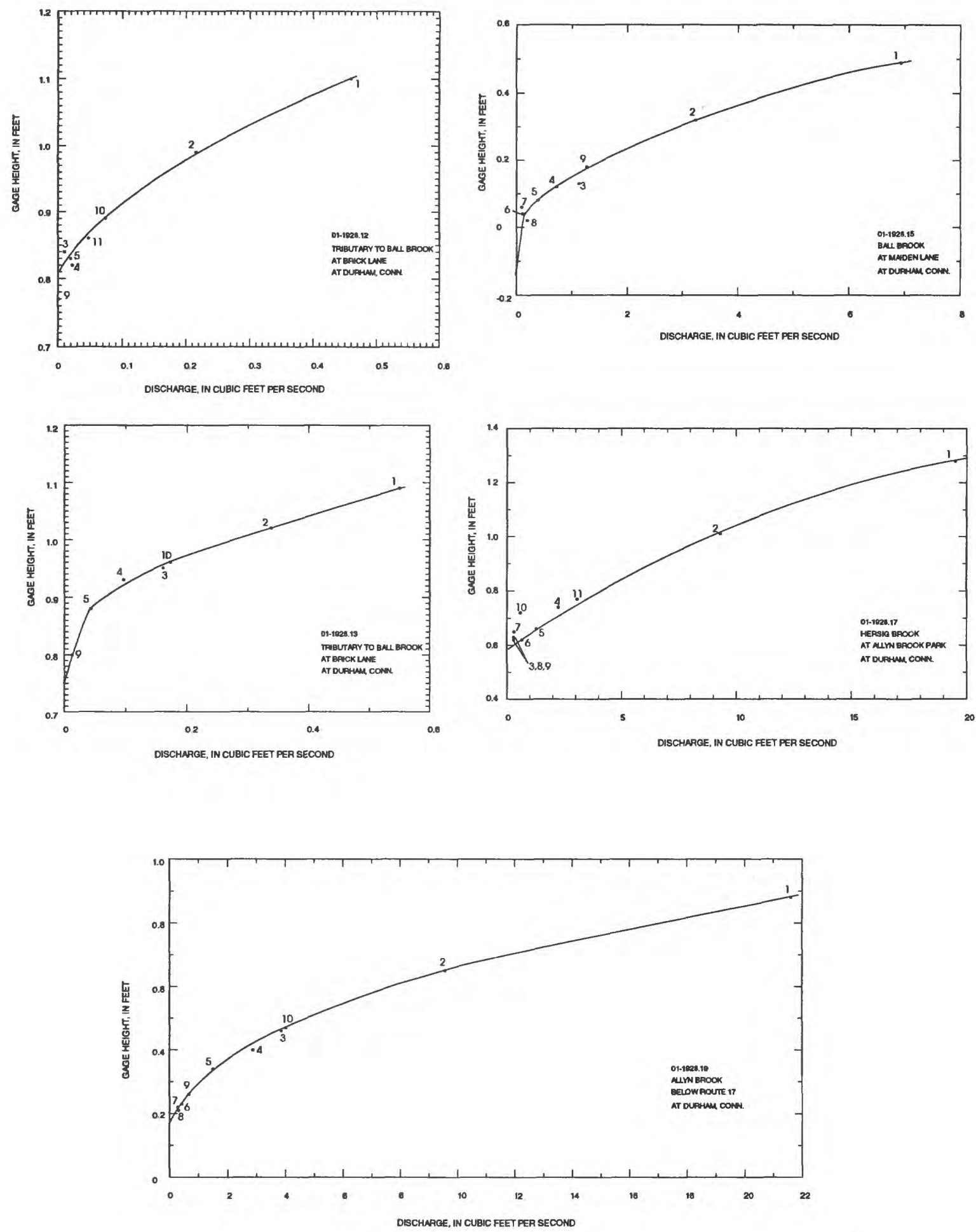

Figure 20. Rating curves for U.S. Geological Survey partial-record streamflow-gaging stations in the Allyn Brook drainage basin, Durham, Conn. (Numbered points are measured discharges used to define the rating curves.) 


\section{WATER QUALITY OF THE DURHAM CENTER AREA}

Water quality is a primary environmental concern in the Durham Center area--particularly the quality of ground water that is used for domestic and institutional (schools and churches) purposes. A complete and accurate characterization of historic or current (1994) water quality is not possible with the existing data. Surface-water-quality data are sparse, with only four sampling events in a 23-year period. Ground-water-quality data are relatively abundant with respect to the number of chemical analyses; more than 1,000 analyses are contained in the data summary compiled by Metcalf and Eddy (1994). These analyses are commonly incomplete, lacking many of the constituents that are of interest, and the analyses are mostly of water samples taken from the wells monitored by Durham Manufacturing Co., Merriam Manufacturing Co., and Regional School District 13. Water from most wells in the study area, other than those that are routinely monitored, has been sampled only once or twice since 1982 . Also, not all wells located beyond the limits of known ground-water degradation have been sampled. Other factors that make it difficult to characterize water quality using existing data are the different procedures used by the many different individuals, companies, and laboratories that have collected or analyzed water samples; the different minimum reporting levels reported for some constituents; the lack of documented sampling protocols; and the apparently limited quality-assurance and qualitycontrol procedures that were used (Metcalf and Eddy, 1994).

Several organic chemicals found in the water have also been detected in samples of soil and glacial sediments and of soil gas at a few sites within the Durham Center area (Roux Associates Inc., 1983, 1988, 1990a; E. Z. Harrison, Connecticut Department of Environmental Protection, written commun., 1982; D.A. Costolnick, Roux Associates Inc., written commun., 1990; Robert La Monica, Leggette, Brashears, and Graham, Inc., written commun., 1992; Haley and Aldrich, 1992). Data on contaminated soils and underlying glacial sediments, available only for the Merriam Manufacturing Co. area property, have been summarized by Metcalf and Eddy (1994) and are not presented in this report. Organic halides and aromatic compounds have been detected; the highest concentrations were generally found in shallow samples collected in 1982 during the earliest investigation. Maximum concentrations of organic compounds in core samples collected at shallow depths (up to $2.5 \mathrm{ft}$ below land surface) in 1982 were: TCE, $3,000 \mu \mathrm{g} / \mathrm{kg} ; 1,1,1-\mathrm{TCA}, 720 \mu \mathrm{g} / \mathrm{kg}$; PCE, $256,000 \mu \mathrm{g} / \mathrm{kg}$; benzene, $25,000 \mu \mathrm{g} / \mathrm{kg}$; toluene, $43,000 \mu \mathrm{g} / \mathrm{kg}$; and xylenes, $11,000 \mu \mathrm{g} / \mathrm{kg}$ (Roux Associates Inc., 1983). Lower concentrations of organic halides were measured in samples collected from greater depths (as deep as 16 to $20 \mathrm{ft}$ ) during subsequent studies (Roux Associates Inc., 1988, 1990a) and these data are summarized by Metcalf and Eddy (1994, tables 3-2, 3-3, and 3-4).

\section{Nature of the Organic Compounds}

The organic compounds detected in samples of water, soil, glacial sediments, and soil gas from the Durham Center area are listed in table 6. Some of the important physicochemical properties of these compounds are summarized in table 6 and additional information is contained in standard references such as Verschueren (1983). The solubilities of these organic compounds in water, although commonly low, are much higher than the maximum contaminant levels (MCL's) established for drinking water by the USEPA (1992). It also should be noted that most of these compounds are highly volatile.

Almost all of the organic compounds in table 6, including those commonly found in the study area, can be present in the subsurface in a vapor phase, an aqueous phase (dissolved in water), or a nonaqueous phase (a separate, undissolved liquid phase that is also termed an 
"immiscible phase"). The vapor phase occurs in the unsaturated zone, and migration of the vapors can contribute to the spread of groundwater contamination. Nonaqueous phase liquids in the subsurface makes it difficult to assess the extent of contamination or to develop feasible alternatives for remediation (Newell and Ross, 1992). The term "NAPL" is used to refer to the undissolved nonaqueous phase liquids. NAPL's are further subdivided on the basis of density into those compounds less dense than water (LNAPL's) and those compounds denser than water (DNAPL's).

Direct observation of NAPL's in either ground water or soils has not been reported by previous investigators. However, the existence of NAPL's, and particularly DNAPL's, is difficult to determine in fractured media (Kueper and others, 1992). Indirect evidence that DNAPL's were, and may still be, in the subsurface includes the long period during which significant quantities of TCE and other organic halides were used in manufacturing, the disposal of wastewater containing these compounds into unlined lagoons and subsurface drains, and high concentrations of TCE (21 and $118 \mathrm{mg} / \mathrm{L}$ ) and other organic halides in water samples collected in August 1982 from wells at Durham Manufacturing Co. (Leggette, Brashears, and Graham, Inc., 1982). The sampled wells (USGS wells D-193 and D-197) were installed in till and were located downgradient from a former storage area for solvents (well D-193) and a leaching field (well D-197). The observed concentrations of TCE were greater than 1 percent of its solubility of $1,100 \mathrm{mg} / \mathrm{L}$; this, according to Newell and Ross (1992), indicates the potential for DNAPL at a site.

Many of the organic compounds in table 6 can degrade under natural conditions into simpler compounds, many of which are also listed in this table. For example, PCE can degrade to TCE, which can degrade into one of the dichloroethenes (most commonly cis-1,2DCE, followed by 1,1-DCE and trans-1,2$\mathrm{DCE})$, which in turn can degrade into vinyl chloride (Vogel and others, 1987; Burston and others, 1993; Fetter, 1993). Degradation pathways for other organic halides into less halogenated compounds are described by Vogel and others (1987). The aromatic compounds, such as benzene and toluene, are also capable of natural degradation and several examples are cited by Fetter (1993, p. 328-329). Experiments by Acton and Barker (1992) indicate that biodegradation of aromatic compounds in anaerobic ground water can be selective. Rapid degradation of toluene was observed in these experiments in contrast to slow degradation of benzene and chlorobenzene.

\section{Sources of Organic Compounds}

As noted in the introduction to this report, the DEP concluded in 1982 that the organic compounds in the ground water resulted from storage, handling, and waste-disposal practices at Durham Manufacturing Co. and Merriam Manufacturing Co. Subsequent investigations have found contaminated ground water at both facilities and contaminated soil and glacial sediments at Merriam Manufacturing Co. (Leggette, Brashears, and Graham, Inc., 1982; Roux Associates Inc., $1983,1988,1990 \mathrm{a})$. Other potential sources of organic compounds have been reported (E. Z. Harrison, Connecticut Department of Environmental Protection, written commun., 1982; John Negrich, Durham Manufacturing Co., written commun., 1984; Durham Water Pollution Control Authority, written commun., 1982; Robert LaMonica, Leggette, Brashears, and Graham, Inc., written commun., 1984, 1992). Low concentrations of some organic constituents also may have resulted from use and disposal of household products containing these chemicals. A recent study of relations between land use and ground-water quality in Connecticut (Grady, 1994) found low concentrations of toluene $(0.2-0.3 \mu \mathrm{g} / \mathrm{L}), 1,1,1-\mathrm{TCA}$ $(0.2-2.1 \mu \mathrm{g} / \mathrm{L}), \mathrm{TCE}(0.2-4.4 \mu \mathrm{g} / \mathrm{L})$, PCE (0.2 - $0.3 \mu \mathrm{g} / \mathrm{L})$, chloroform (0.2 -1.3 $\mu \mathrm{g} / \mathrm{L})$, and methylene chloride $(8.8-11 \mu \mathrm{g} / \mathrm{L})$ to be 


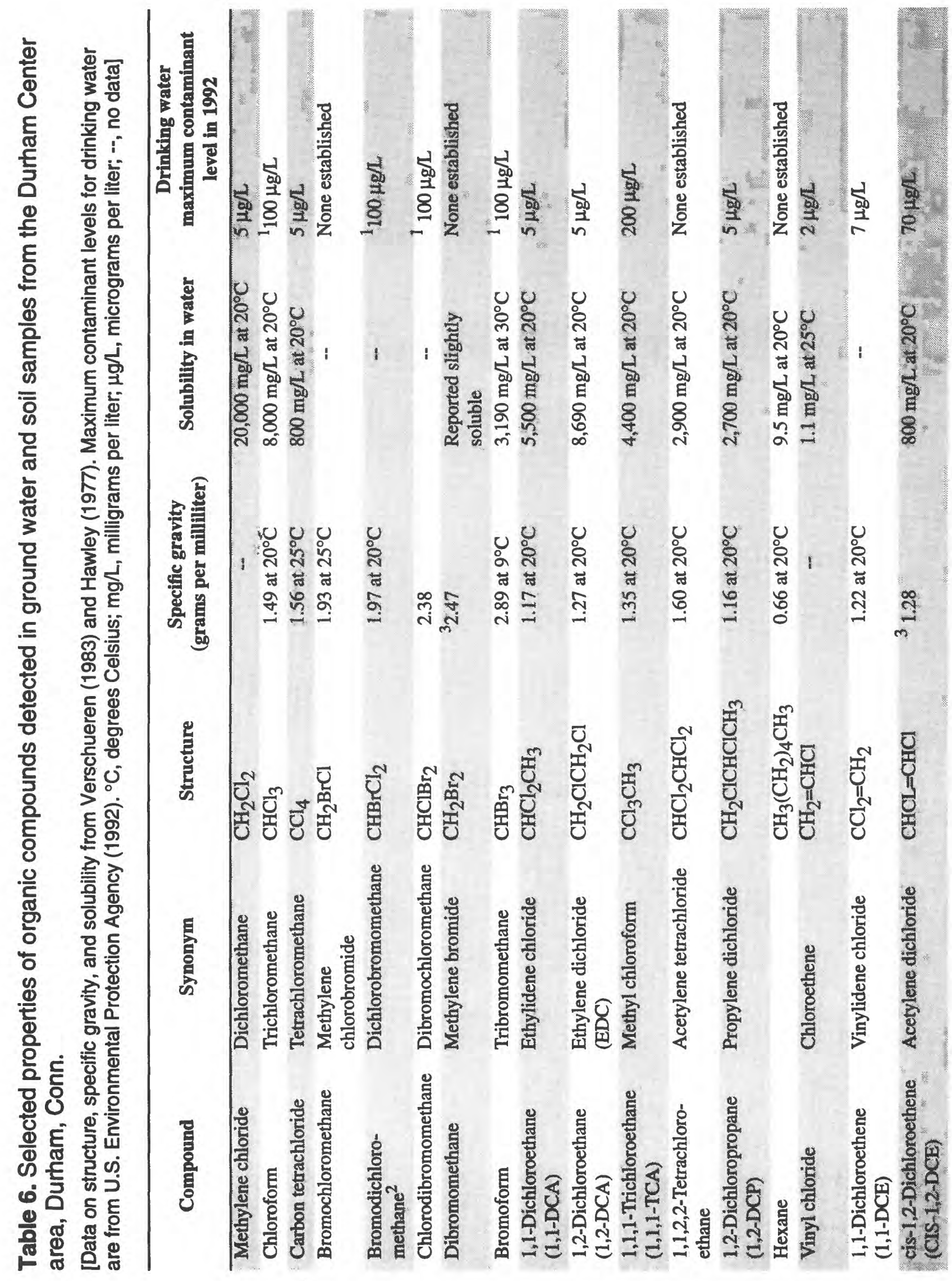




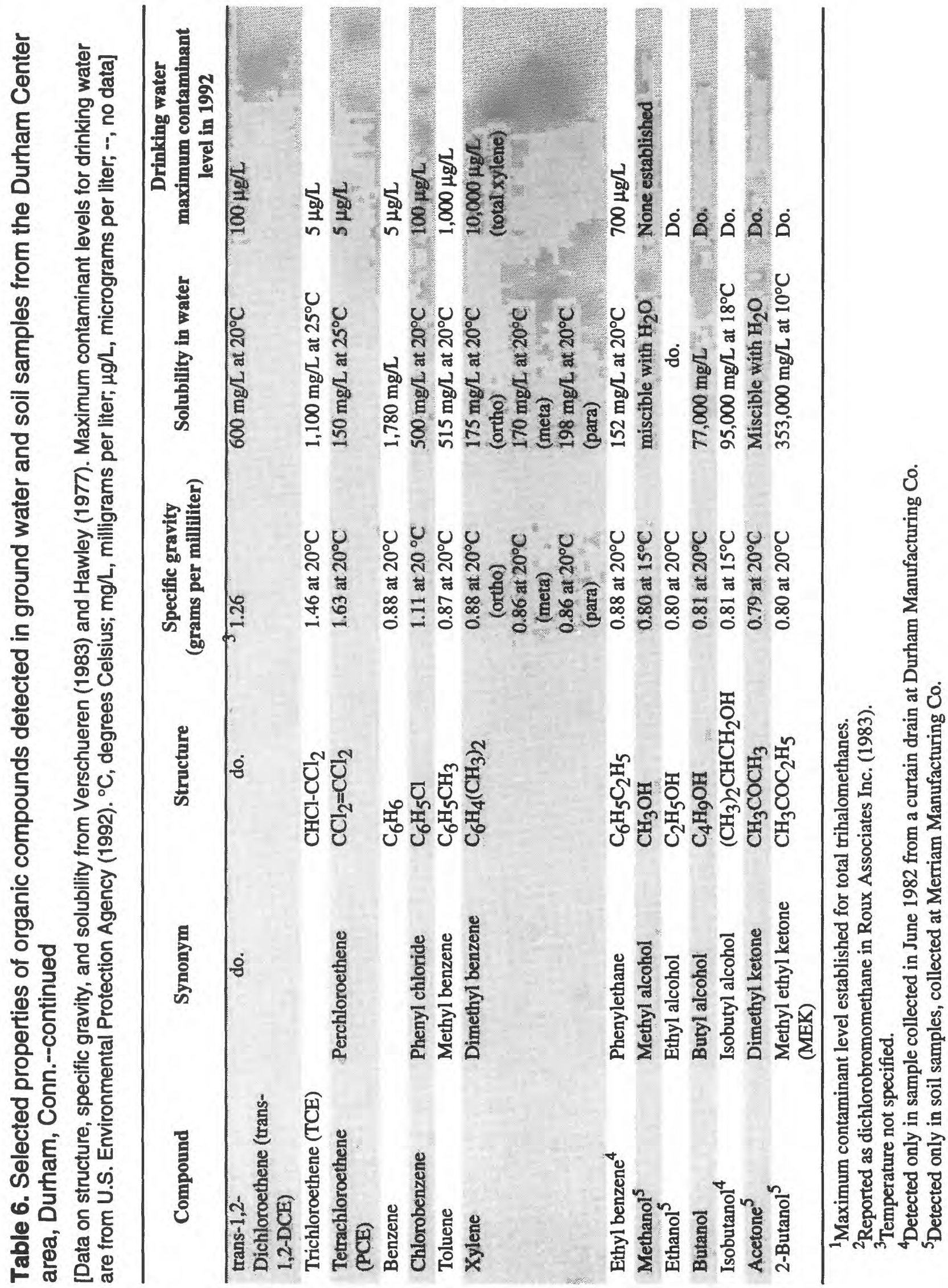


widespread in samples of ground water collected from the upper part of the saturated zone beneath unsewered residential areas. The presence of these compounds, in some cases, was ascribed to use and disposal of household chemical products through septic tanks (Grady, 1994, p. B29). Higher concentrations of these constituents are commonly associated with industrial and (or) commercial land use.

Some organic compounds have been reintroduced into the subsurface in the Durham Center area. Ground water containing organic compounds that is withdrawn by wells is largely discharged into septic tanks or onto the ground. Until effective filtration units were placed on water-supply systems with high concentrations of organic chemicals, these discharges of degraded water probably affected the subsurface distribution and concentrations of these chemicals.

The principal organic halides that were used and their reported periods of use at Durham Manufacturing Co. are TCE (from the 1940's to 1973), 1,1,1-TCA (from 1973 to 1976), and methylene chloride (since 1973). Merriam Manufacturing Co. used TCE and methylene chloride from an unspecified time until 1986 when they switched to 1,1,1-TCA (Caren Spieske, Connecticut Department of Environmental Protection, written commun.,1986). No information was found in the USGS review of reports and files that would allow estimates of the quantities of these organic chemicals that were released to the subsurface. The other organic compounds that were detected in samples of water, soil, and glacial sediments were reportedly used by one, or both of these companies, or are degradation products of compounds that were used (G. G. Bonadies, Connecticut Dept. of Health Services, written commun., 1970; Beth Flores, Connecticut Department of Environmental Protection, written commun., 1981; Kenneth Major, Connecticut Department of Environmental Protection, written commun., 1982; Leggette, Brashears and Graham, Inc., 1982;
M. A. Dones, Connecticut Department of Environmental Protection, written commun., 1984; Daniel Pearson, Merriam Manufacturing Co., written commun., 1987).

\section{Quality of Surface Water}

Streams in the study area were sampled at least four times during 1970-93. Water from a small artificial pond that receives wastewater from Durham Manufacturing Co. also was analyzed intermittently. The DOHS collected and analyzed samples from Ball Brook and a tributary to Ball Brook in March 1970 as part of the investigation of contamination at the Frank W. Strong School. Samples from Ball Brook and Hersig Brook were collected and analyzed in August 1982 as part of the Durham Manufacturing Co. study by Leggette, Brashears, and Graham, Inc. (1982). Roux Associates Inc. collected and analyzed samples from three locations on a tributary to Ball Brook in October 1989 (Roux Associates Inc., 1990a, 1990b). The latest surface-water sampling was done for USEPA by Metcalf and Eddy Inc. in July and August 1993. Nine samples, collected from Ball Brook, a tributary to Ball Brook, Hersig Brook, and Allyn Brook, were analyzed by a USEPA contract laboratory. Approximate locations of all surface-water-quality sampling sites are shown in figure 21.

The 1970 analyses by DOHS are qualitative, indicating only that an organic compound is present as a major or trace component of the sample (G. G. Bonadies, Connecticut Department of Health Services, written commun., 1970). The analyses are also limited to a few organic chemicals. Chloroform was the only major component found in the samples collected from Ball Brook and one of its tributaries. The other organics reported in the DOHS analyses include "petroleum ether," ethyl ether, and tetrachloroethane, all of which were contained in a sample collected from a site on Ball Brook east of Durham Manufacturing Co. Analytical data for surface-water samples collected in August 1982 are contained in Leggette, Brashears, and Graham, Inc. (1982) 


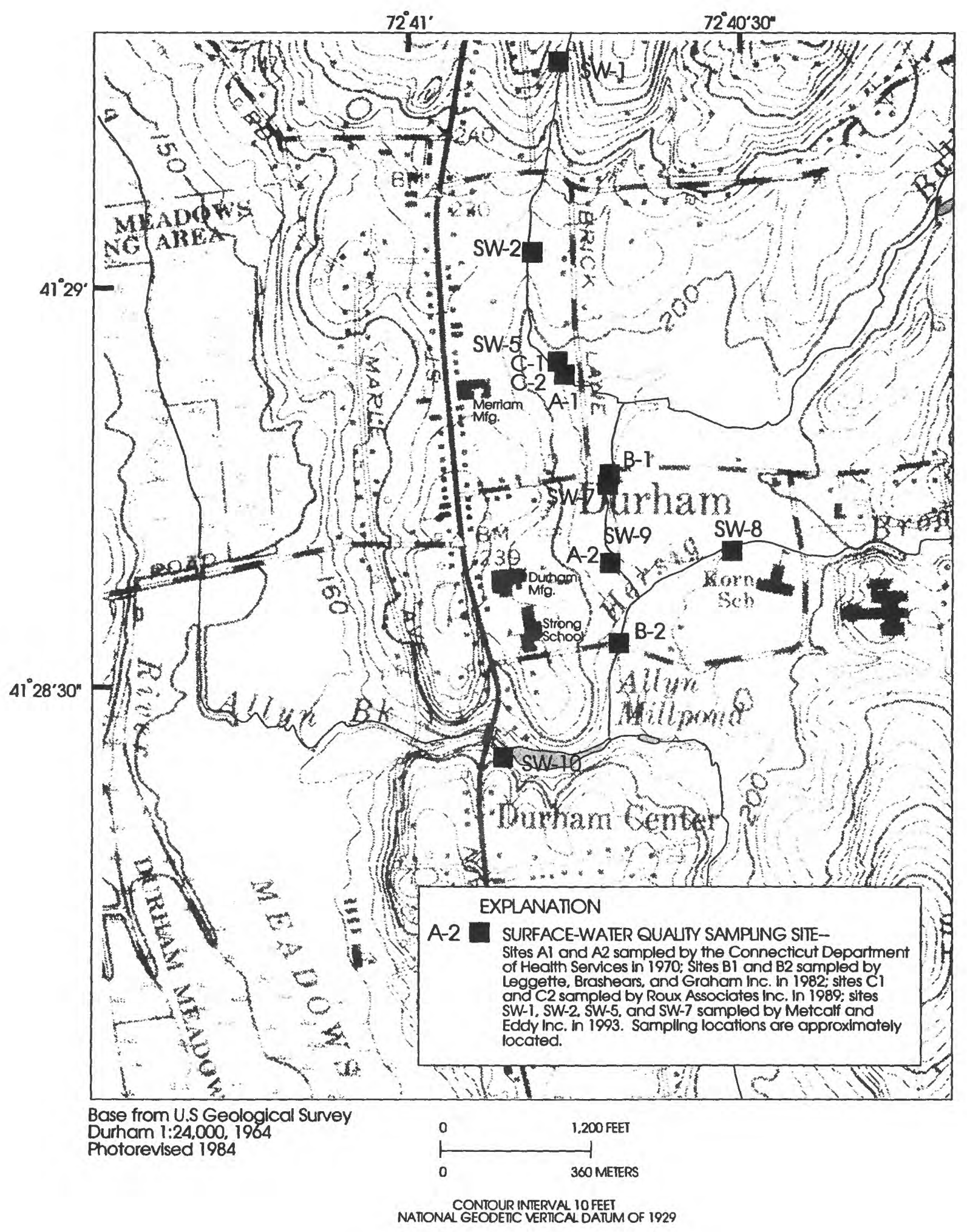

Figure 21. Locations of surface-water-quality sampling sites in the Durham Center area, Durham, Conn. 
and are summarized in table 7. Analytes include selected inorganic and organic constituents, total dissolved solids, total organic carbon, total organic halides, and $\mathrm{pH}$. These data show concentrations of inorganic constituents and total dissolved solids that are within the observed range for natural streams in this region under low-flow conditions (Weiss and others, 1982). TCE was detected at low concentration $(1.6 \mu \mathrm{g} / \mathrm{L})$ at the upstream site on Ball Brook and at higher concentration (5.0 $\mu \mathrm{g} / \mathrm{L}$ ) at the downstream site where 1,1,1-TCA was also present. The concentration of TCE at the downstream location was equal to the present MCL in drinking water (table 6). Streamflow on the sampling date in this part of Connecticut was relatively low--about 80-percent duration, as estimated from daily flow records of the Coginchaug River collected at USGS station 01192883. Streamflow at this flow duration consists largely or entirely of ground-water runoff. The organic halides detected in the samples were likely transported through the shallow ground-water flow system that discharges to Ball and Hersig Brooks; or their source could have been overflow from the then-existing wastewater lagoons at the manufacturing facilities that flowed eastward over the land surface to Ball Brook.

The three water samples collected on October 16, 1989, from two tributaries to Ball Brook located east of Merriam Manufacturing Co., were analyzed for a suite of organic halides using USEPA method 8010 (Roux Associates Inc., 1990a, p. 4-21). One sample was collected where the main tributary enters the Merriam property ( $\mathrm{Cl}$ in fig. 21 ); the other two samples were collected near Brick Lane (C2 in fig. 21). None of these organic compounds were detected in any of the samples.

Water samples collected in July 1993 for USEPA were analyzed for 24 inorganic constituents and an extensive suite of organic compounds, including volatile and semivolatile organic compounds, semivolatiles, pesticides, and polychlorinated biphenyls. The analyses and field measurements of water temperature, conductance, $\mathrm{pH}$, and dissolved oxygen are presented in the report by Metcalf and Eddy (1994, appendix I). Concentrations of inorganic constituents for which drinking water MCL's have been established (U.S. Environmental Protection Agency, 1992) did not exceed those limits. The concentrations of iron (as high as $4.2 \mathrm{mg} / \mathrm{L}$ ) and manganese (as high as $1.0 \mathrm{mg} / \mathrm{L}$ ) in water samples collected at sites SW-1, SW-6, SW-7, SW-9, and SW-10 (fig. 21) did exceed the National Secondary Drinking Water Standards of $0.3 \mathrm{mg} / \mathrm{L}$ and $0.05 \mathrm{mg} / \mathrm{L}$, respectively (U.S. Environmental Protection Agency, 1992). The inorganic analytical data were also compared to ranges of concentrations for natural streams at low flows reported by Weiss and others (1982, table 22). For the constituents that were common to both data sets (calcium, iron, magnesium, manganese, potassium, and sodium), only the iron and potassium concentrations at site SW-1 were above the range observed for natural streams in this part of Connecticut.

No organic compounds were detected at or above the reporting limits of the analysis, with the exception of cis-1,2-DCE, which had a reported concentration of $0.5 \mu \mathrm{g} / \mathrm{L}$ at site SW-9 (fig. 21) (Metcalf and Eddy, 1994, table 3.7). Estimated flow duration of local streams was also low during the July sampling (about 90-percent duration), and water in the sampled streams was likely ground-water runoff. The near absence of organic halides in the 1993 samples may indicate that these compounds are no longer being discharged into the streams from any source or that organic compounds entering the streams are present at concentrations below the analytical reporting limits because of dilution or rapid volatilization.

The pond east of Durham Manufacturing Co. that receives wastewater from this facility was sampled and analyzed several times between 1985 and 1988. Low concentrations of TCE (up to $20 \mu \mathrm{g} / \mathrm{L}$ ), 1,1,1-TCA (up to 12 $\mu \mathrm{g} / \mathrm{L}$ ) and PCE (up to $7 \mu \mathrm{g} / \mathrm{L}$ ) were reported 
Table 7. Analytical data for surface-water samples collected at Durham, Conn. on August 9, 1982

[Data from Leggette, Brashears, and Graham, Inc.,1982. Sampling locations are shown in figure 21. $\mathrm{mg} / \mathrm{L}$, milligrams per liter; $\mu \mathrm{g} /$, micrograms per liter; <, less than]

\begin{tabular}{|c|c|c|}
\hline \multirow[b]{2}{*}{ Constituent or property } & \multicolumn{2}{|c|}{ Location } \\
\hline & $\begin{array}{c}\text { Ball Brook at Maiden } \\
\text { Lane }\end{array}$ & $\begin{array}{l}\text { Hersig Brook at } \\
\text { Pickett Road }\end{array}$ \\
\hline Arsenic (mg/L) & $<0.05$ & $<0.05$ \\
\hline Barium (mg/L) & .53 & .18 \\
\hline Cadmium (mg/L) & $<.01$ & $<.01$ \\
\hline Chromium (mg/L) & $<.05$ & $<.05$ \\
\hline Lead (mg/L) & $<.05$ & $<.05$ \\
\hline Mercury (mg/L) & $<.002$ & $<.002$ \\
\hline Selenium (mg/L) & $<.01$ & $<01$ \\
\hline Silver $(\mathrm{mg} / \mathrm{L})$ & $<.01$ & $<.01$ \\
\hline Calcium (mg/L) & 10.8 & 12.0 \\
\hline Chloride (mg/L) & 11 & 10 \\
\hline Total dissolved solids (mg/L) & 100 & 94 \\
\hline $\mathrm{pH}$ (units) & 7.1 & 7.3 \\
\hline Total organic carbon (mg/L) & 17 & 14 \\
\hline $1,1,1$-trichloroethane $(\mu \mathrm{g} / \mathrm{L})$ & $<1$ & 3.4 \\
\hline 1,1,2-trichloroethene $(\mu \mathrm{g} / \mathrm{L})$ & 1.6 & 5 \\
\hline Tetrachloroethene $(\mu \mathrm{g} / \mathrm{L})$ & $<1$ & $<1$ \\
\hline Methylene chloride (mg/L) & $<.20$ & $<.20$ \\
\hline Methyl ethyl ketone (mg/L) & $<.20$ & $<.20$ \\
\hline Benzene (mg/L) & $<.05$ & $<.05$ \\
\hline Toluene (mg/L) & $<.20$ & $<.20$ \\
\hline Xylenes (mg/L) & $<.1$ & $<.1$ \\
\hline Total organic halides $(\mu \mathrm{g} / \mathrm{L})$ & 2 & 8 \\
\hline
\end{tabular}

(Metcalf and Eddy, 1994, appendix B). This pond is reportedly unlined, and the bottom is close to the surface of the bedrock (John Negrich, Durham Manufacturing Co., oral commun., 1993).

\section{Quality of Ground Water}

The major water-quality problem in the Durham Center area is the deterioration of ground-water quality in the bedrock-aquifer system as a result of human activities. At least 20 synthetic organic compounds were detected in ground-water samples collected from this area since January 1982 (table 6). The most commonly detected compounds were the organic halides TCE, 1,1,1-TCA, and PCE. Twenty-three other aliphatic and aromatic hydrocarbons were detected less frequently (table 6) and other synthetic organic compounds may have been present at concentra- 
tions below detection levels or were not included in the analysis.

The magnitude and extent of the degradation of ground-water quality in the glacial sediments (till and stratified drift) is not as well-defined as it is in the underlying bedrock. Only the ground water in the glacial sediments beneath the Durham Manufacturing Co. property and a wetland area directly east of Merriam Manufacturing Co. is known to have been degraded by organic chemicals (Leggette, Brashears, and Graham, Inc., 1982; Roux Associates Inc., 1990b). Some of the wells elsewhere in the Durham Center area that contained organic compounds in water, however, may be completed in till; records identifying the aquifer were not found for every well. Six observation wells (USGS wells D-193 to 195 and D-197 to 199) completed in till at Durham Manufacturing Co. were sampled on August 9, 1982, and the resulting analyses are contained in the reports by Leggette, Brashears, and Graham, Inc. (1982) and Metcalf and Eddy (1994, appendix D-2). The highest known concentrations of TCE $(118,000 \mu \mathrm{g} / \mathrm{L}), 1,1,1-\mathrm{TCA}(9,300 \mu \mathrm{g} / \mathrm{L}), \mathrm{PCE}$ $(2,900 \mu \mathrm{g} / \mathrm{L})$, methylene chloride $(7,100$ $\mu \mathrm{g} / \mathrm{L})$, methyl ethyl ketone $(2,000 \mu \mathrm{g} / \mathrm{L})$, toluene $(37,000 \mu \mathrm{g} / \mathrm{L})$, and xylenes $(310 \mu \mathrm{g} / \mathrm{L})$ in water from the Durham Center area were detected in the samples from wells D-193 and D-197 (fig. 7). These two wells were resampled on August 26, 1982, and the concentrations of TCE reportedly declined from 21,200 to $13,400 \mu \mathrm{g} / \mathrm{L}$ in D-193 and from 118,000 to $34,000 \mu \mathrm{g} / \mathrm{L}$ in D-197. Large decreases in concentrations of 1,1,1-TCA and PCE were also reported (Leggette, Brashears, and Graham, Inc., 1982). The last known sampling of these wells was in March 1983, by which time concentrations of TCE had declined to $610 \mu \mathrm{g} / \mathrm{L}$ in D-193 and $6,500 \mu \mathrm{g} / \mathrm{L}$ in D-197 (Robert LaMonica, Leggette, Brashears, and Graham, Inc., written commun., 1983).

One inorganic constituent, barium, was also detected in concentrations greater than its drinking water MCL of $1 \mathrm{mg} / \mathrm{L}$ (U.S. Environmental Protection Agency, 1992) in five of the six monitoring wells sampled on August 9, 1982 (all except well D-195). The source of the elevated barium concentrations (as high as $8.5 \mathrm{mg} / \mathrm{L}$ ) could not be definitely established. Barite (barium sulfate) is widely used as a pigment in paint (Parker, 1992, p. 108), and the high concentrations may reflect its presence in wastewater containing paint residue that was disposed of in this area. Barite also occurs locally in the Portland Formation (Hubert and others, 1992). No analyses of barium in ground water from the Portland Formation were found in USGS files, but Grady (1994, table 5) reported that barium concentrations greater than $100 \mu \mathrm{g} / \mathrm{L}$ are common in ground water from stratified-drift aquifers underlying residential, commercial, and industrial land in Connecticut.

The $500 \mathrm{mg} / \mathrm{L}$ concentration of chloride detected in water collected from well D-197 on August 9, 1982, exceeded the maximum contaminant level of $250 \mathrm{mg} / \mathrm{L}$ specified in the National Secondary Drinking Water Regulations (U.S. Environmental Protection Agency, 1992). The high chloride and an elevated calcium concentration were ascribed to use of road salt and calcium chloride treatment of wastewater by the Durham Manufacturing Co. (Leggette, Brashears, and Graham, Inc., 1982).

Four shallow wells (USGS wells D-200 to D-203) in the wetland area between Merriam Manufacturing Co. and Brick Lane (fig. 7) were sampled on October 12, 1989; at the same time samples of water were collected from nearby streams (Roux Associates Inc., 1990a, 1990b). Organic halides, including TCE (13 to $289 \mu \mathrm{g} / \mathrm{L}), 1,1,1-\mathrm{TCA}(12 \mu \mathrm{g} / \mathrm{L})$, PCE $(7.0 \mu \mathrm{g} / \mathrm{L})$, trans-1,2-DCE (34 to 77 $\mu \mathrm{g} / \mathrm{L})$, and 1,1-DCA $(5.0 \mu \mathrm{g} / \mathrm{L})$, were detected in samples from wells D-200, D-201, and D202 (Roux Associates Inc., 1990a, table 4-6). These wells are all less than $5 \mathrm{ft}$ deep and their logs (Roux Associates Inc., 1990b, appendix B) indicate that they are completed in either stratified drift or postglacial sand, silt, and 
clay. The water-table gradient in this wetland area is southeastward, away from the Merriam Manufacturing Co. No organic compounds were detected in water from well D-203, which is farthest downgradient.

Data on inorganic constituents in ground water from the sedimentary bedrock are sparse; they consist of a partial analysis of trace metals in a sample collected in 1982 from the Merriam Manufacturing Co. well (USGS well D-211) (Roux Associates Inc., 1983), DOHS partial analyses of samples collected between 1984 and 1991 from 14 wells in the Durham Center area (William Milardo, Durham Health Department, written commun., 1993), and USGS analyses of samples collected in 1971 and 1972 from 3 wells near Durham Center (USGS wells D-50, D-107, and D-108). The water sample from well D211 contained $140 \mu \mathrm{g} / \mathrm{L}$ of copper, $30 \mu \mathrm{g} / \mathrm{L}$ of chromium, and $240 \mu \mathrm{g} / \mathrm{L}$ of barium; nondetected analytes were lead and hexavalent chromium (Metcalf and Eddy, 1994, appendix E). The DOHS analyses included few constituents and varied with respect to the analytes. Ranges of concentrations or values and the number of analyses (in brackets) for various constituents or properties are: sodium, 13-32 $\mathrm{mg} / \mathrm{L} \mathrm{[14]}$; sulfate, $17-35 \mathrm{mg} / \mathrm{L}$ [13]; nitrate, $0.1-5.1 \mathrm{mg} / \mathrm{L}$ [11]; chloride, 11-56 mg/L [8], hardness, 110$190 \mathrm{mg} / \mathrm{L}$ [14]; and $\mathrm{pH}, 7.6-8.2$ [14]. The more comprehensive USGS analyses are summarized in table 8. None of the constituents in these analyses, except for nitrate in water from USGS well D-108, exceeded the MCL's in the National Primary Drinking Water Regulations (U.S. Environmental Protection Agency, 1992). The high nitrate $(19 \mathrm{mg} / \mathrm{L})$ and potassium $(6.4 \mathrm{mg} / \mathrm{L})$ concentrations in the water sample from well D-108 indicate that contamination may be from agricultural sources.

Almost all the organic compounds in table 6 were detected in ground-water samples collected from wells that tap the bedrock-aquifer system. TCE is the most widespread constituent and was detected in all but a few of the water samples collected from bedrock wells since January 1982. Concentrations of other organic halides, particularly 1,1,1-TCA, are also high (in excess of established MCL's for drinking water) in many of the analyses (Metcalf and Eddy, 1994). In several of the wells monitored by Merriam Manufacturing Co., the concentration of 1,1,1-TCA is commonly greater than TCE and may be as high as several hundred micrograms per liter (Metcalf and Eddy, 1994).

The distribution of TCE in ground-water samples analyzed during January 1982 - February 1983 , when widespread contamination was first recognized, is shown in figure 22. Observed distributions of TCE concentrations in water from bedrock wells in the north and central part of the study area in September 1989, December 1989, and January 1990 have been depicted by Roux Associates Inc. (1990a, figs. 4-1 and 4-2). The maximum concentration of TCE in water samples from monitored bedrock wells in the first half of 1993 is shown in figure 23. The highest observed concentrations of TCE in water from the bedrock-aquifer system to date were $4,500 \mu \mathrm{g} / \mathrm{L}$, measured in a sample collected from USGS well D-191 (Strong School) in October 1983 (Regional School District 13, written commun., 1993); $5,491 \mu \mathrm{g} / \mathrm{L}$ in a sample collected from USGS well D-211 (Merriam Manufacturing Co. production well) on September 15, 1988 (Roux Associates Inc., 1991a); and 4,995 $\mu \mathrm{g} / \mathrm{L}$ in a sample collected from a well at 199 Main Street (Distasio residence, directly south of Durham Manufacturing Co.) in October 1992 (William Warzecha, Connecticut Department of Environmental Protection, written commun., 1993). Concentrations of TCE greater than $100 \mu \mathrm{g} / \mathrm{L}$ shown in figures 22 and 23 , and reported by Roux Associates Inc. (1990a), are consistently found in water samples from wells at the manufacturing facilities and to the southwest and south. The southwestern direction is also the strike direction of the primary fractures in the bedrock as determined from bore- 
Table 8. Analysis of water samples from wells tapping the Portland Formation near Durham Center, Durham, Conn.

[All analyses by U.S. Geological Survey; $\mathrm{mg} / \mathrm{L}$, milligrams per liter; $\mu \mathrm{g} / \mathrm{L}$, micrograms per liter; ${ }^{\circ} \mathrm{C}$, degrees Celsius; $\mu \mathrm{S} / \mathrm{cm}$, microsiemens per centimeter; --, no data reported]

\begin{tabular}{|c|c|c|c|}
\hline \multirow[b]{2}{*}{ Constituent or property } & \multicolumn{3}{|c|}{ Local well number and date sampled } \\
\hline & D-50 (3-25-71) & D-107 (4-6-72) & D-108 (4-6-72) \\
\hline Temperature $\left({ }^{\circ} \mathrm{C}\right)$ & 11.0 & 11.5 & $=9.0$ \\
\hline $\begin{array}{l}\text { Specific conductance }(\mu \mathrm{S} / \mathrm{cm}) \text { at } \\
25^{\circ} \mathrm{C}\end{array}$ & 430 & 433 & 608 \\
\hline pH (standard units) & 8.3 & 8.0 & 7.6 \\
\hline Carbon dioxide $\left(\mathrm{mg} / \mathrm{L}\right.$ as $\mathrm{CO}_{2}$ ) & .1 & 3.6 & 8.4 \\
\hline Alkalinity, field (mg/L as $\mathrm{CaCO}_{3}$ ) & 177 & 185 & 171 \\
\hline Nitrate, total (mg/L as $\mathrm{N})$ & 0.4 & 0.0 & 19.0 \\
\hline Hardness, total (mg/L as $\mathrm{CaCO}_{3}$ ) & 160 & 170 & 270 \\
\hline $\begin{array}{l}\text { Hardness, noncarbonate ( } \mathrm{mg} / \mathrm{L} \text { as } \\
\mathrm{CaCO}_{3} \text { ) }\end{array}$ & 0 & 0 & 99 \\
\hline Calcium (mg/L) & 37 & 46 & 85 \\
\hline Magnesium (mg/L) & 17 & 14 & 14 \\
\hline Sodium (mg/L) & 33 & 32 & 10 \\
\hline Potassium (mg/L) & 1.0 & 2.0 & 6.4 \\
\hline Chloride $(\mathrm{mg} / \mathrm{L})$ & 7.5 & 5.5 & 29 \\
\hline Sulfate $(\mathrm{mg} / \mathrm{L})$ & 38 & 41 & 28 \\
\hline Fluoride $(\mathrm{mg} / \mathrm{L})$ & 0.5 & 0.2 & 0.1 \\
\hline Silica (mg/L) & - & 12 & 15 \\
\hline Iron $(\mu g / L)$ & 50 & 260 & 130 \\
\hline Manganese $(\mu \mathrm{g} / \mathrm{L})$ & 0 & 230 & 0 \\
\hline Solids, dissolved (mg/L) & 244 & 264 & 290 \\
\hline
\end{tabular}

hole and surface-geophysical data, whereas a north-south direction coincides with the strike of the bedding in the sedimentary rocks and the secondary strike direction of bedrock fractures (fig. 16).

Concentrations of TCE and other organic compounds in ground water in the Durham Center area vary with respect to time as well as location. Concentrations of selected ethene- series organic halides measured in water samples collected from bedrock wells are shown in figures 24 through 27 . The locations of the wells are shown in figure 28. These graphs (fig. 24 to 27) show there can be large differences in measured concentrations with respect to time and physical location. No statistical analyses have been performed to determine general or seasonal trends. 
Reported concentrations, including nondetections, of TCE and other ethenes in water samples collected from USGS well number D-191 at the Frank W. Strong School, for March 1981 through August 1993, are shown in figure 24 . The water from this well, located in the southern part of the study area (fig. 28), is the first known to have been contaminated. The graph in figure 24 shows consistently high levels of TCE, generally greater than $1,000 \mu \mathrm{g} / \mathrm{L}$. PCE is reported throughout much of the period of record, except for late 1982 until early 1985, and early 1992 through the end of the period. The other constituents, 1,1-DCE, trans-1,2-DCE, and cis1,2-DCE, are degradation products of TCE and PCE that were only analyzed intermittently and concentrations fluctuated considerably. Many of the available organic analyses do not include compounds that are degradation products of the principal contaminants (TCE, 1,1,1-TCA, and PCE) and, therefore, an assessment of water quality is incomplete.

The reported concentrations of TCE and other ethenes in water samples collected from USGS well number D-78 from May 1986 through May 1993 are shown in figure 25. The water from this well, located in the northern part of the study area, also shows high levels of TCE throughout the period of record, although concentrations are lower than at well D-191. Analyses do not consistently include PCE, 1,1-DCE, and trans-1,2-DCE until 1988.

Reported concentrations of TCE, including nondetections, in water samples collected from three wells (USGS well D-191 and two unnumbered wells) in the southern part of the Durham Center area from January 1985 to August 1993 are shown in figure 26. The three wells are in close geographical proximity and a visual inspection of the graph indicates a hydrologic relation among these data. The analytical data appear to form a band that oscillates around $1,000 \mu \mathrm{g} / \mathrm{L}$, with a slight decrease in concentrations beginning in 1987 and continuing through early 1989 , and a general increase thereafter. Samples collected from well D-191 in the spring of $1992 \mathrm{had}$ relatively low concentrations of TCE.

The water-quality data for samples collected at many of the wells show that the concentration of TCE generally stays within relatively narrow ranges ( 1 or 2 orders of magnitude) over periods of several years, although these ranges may vary considerably from one well to another. Reported concentrations, including nondetections, of TCE in water samples collected from three nearby unnumbered wells at 159,174 , and 188 Main St. are shown in figure 27. These wells were all sampled a minimum of 20 times between February 1985 and August 1993. These data were selected to graphically illustrate how TCE concentrations in water samples from individual wells commonly appear to stay within a defined range and that these ranges may differ by about an order of magnitude.

Several patterns in the concentration of TCE in ground water are shown by the data from other bedrock wells in the Durham Center area (Metcalf and Eddy, 1994, appendix L). Some patterns are of concern because they indicate limited data that may lead to erroneous conclusions about long-term trends, depending on sampling periods and frequency. For example, data on TCE in water samples collected from unnumbered wells at 133 Maple Ave., 188 Main St., 199 Main St., and 202 Main St., located in figure 28, show periods of several months during which concentrations were consistently low (even less than the drinking water MCL of $5 \mu \mathrm{g} / \mathrm{L}$ ) that are interrupted by significant increases. The concentrations reportedly increased most dramatically at 199 Main St., where in 1992 the concentration of TCE rose from 17 to $4,995 \mu \mathrm{g} / \mathrm{L}$ and then declined to $8 \mu \mathrm{g} / \mathrm{L}$ between successive sampling events (Metcalf and Eddy, 1994, appendixes K and L). 


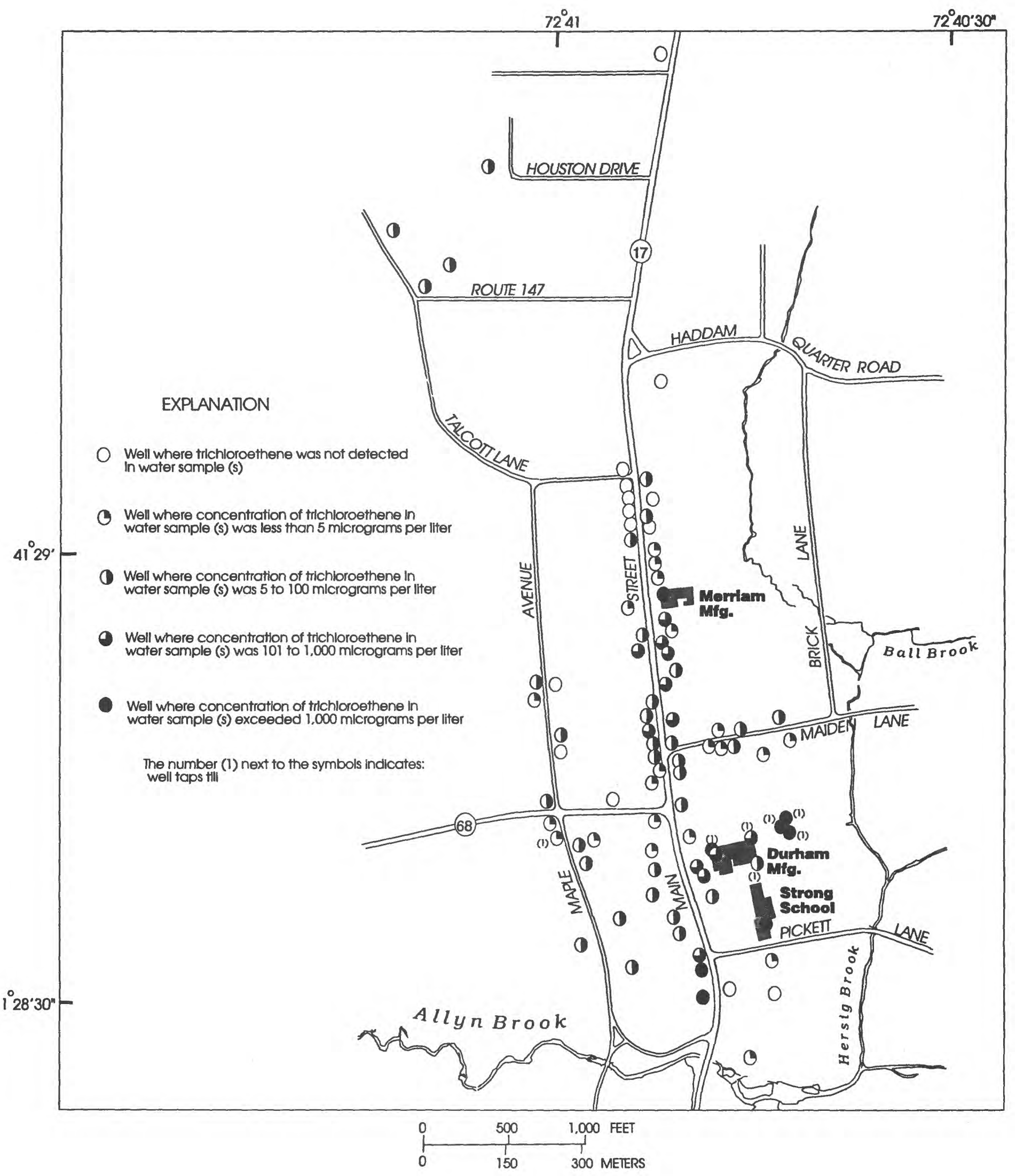

Figure 22. Concentrations of trichloroethene in water samples from bedrock wells in the Durham Center area, Duham, Conn., January 1982-February 1983. 


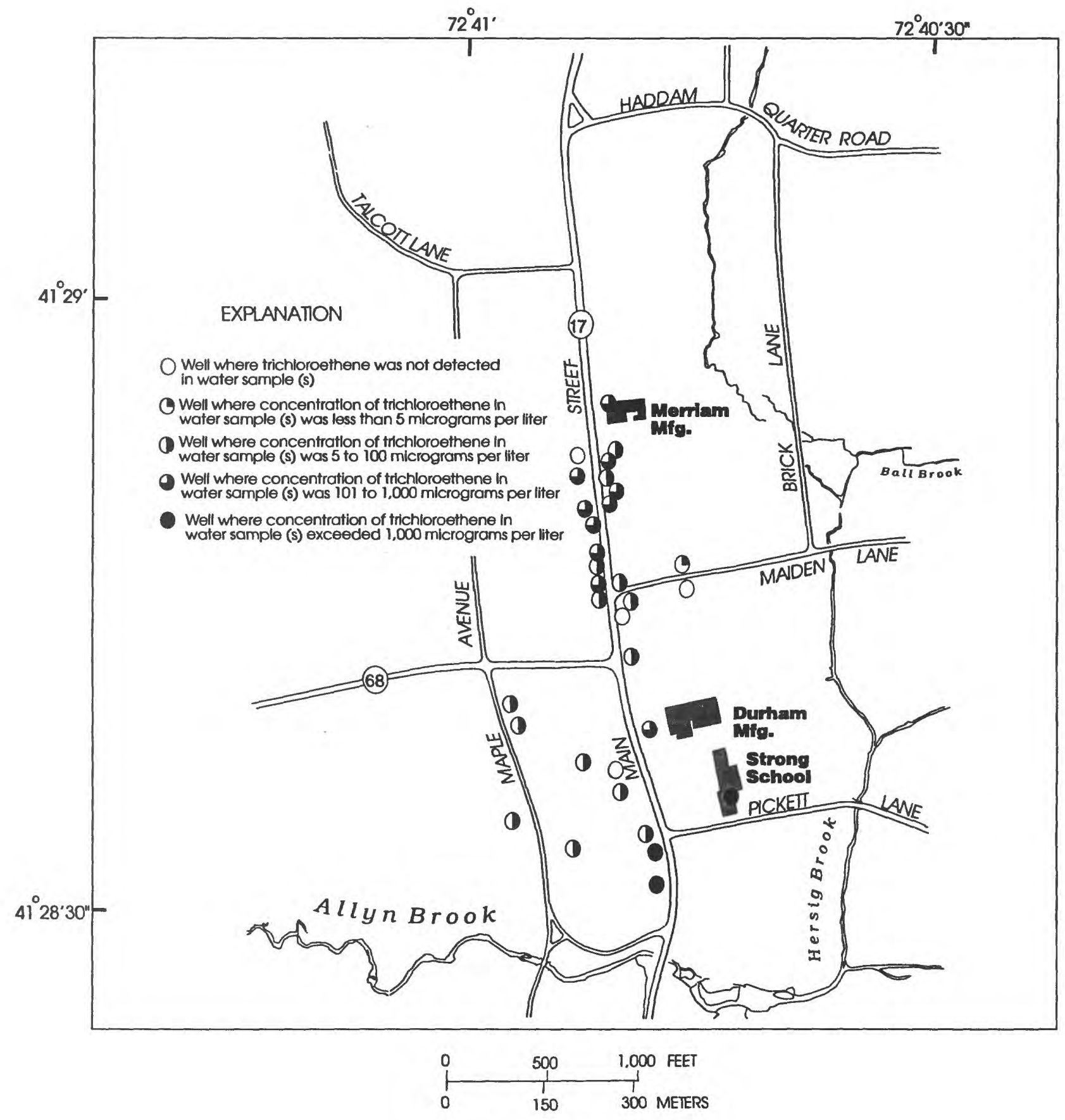

Figure 23. Maximum concentrations of trichloroethene in water samples from bedrock wells in the Durham Center area, Durham, Conn., January 1993-June 1993. 


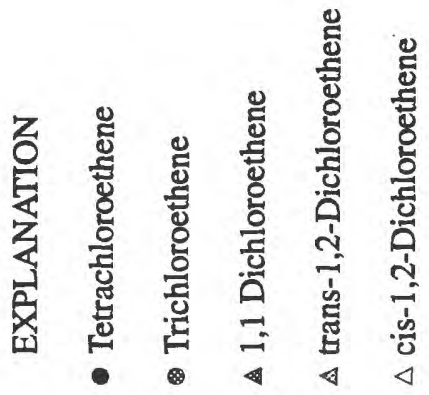

망

동

क :

응

它

วं

들

สํำ

4

तั के

क人

든

힝

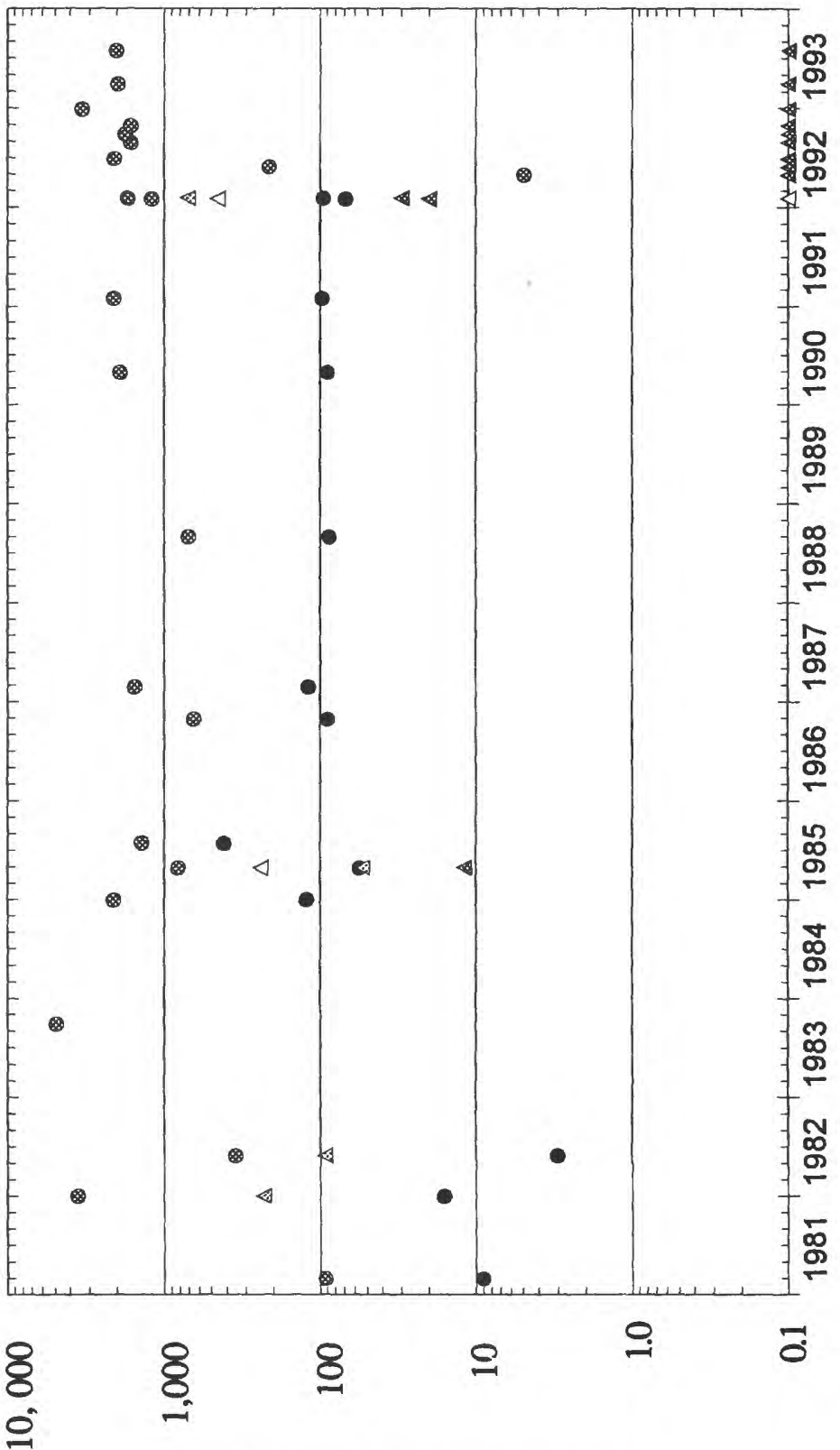

3

है

은

인

응

E

『

ธ。

ส

드 을

क

$\Phi$

Ф등

잉

$\infty$

중

흥

공

은

도. 드

옹

옹

잉

\%

क

흥

융

응

준

ऐ

잉 등

$-0$

ก

인

흔드

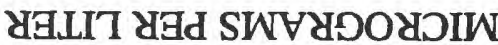

证员

NI ‘SGGTVH DINVDYO HO SNOILVY.LNGONOD 

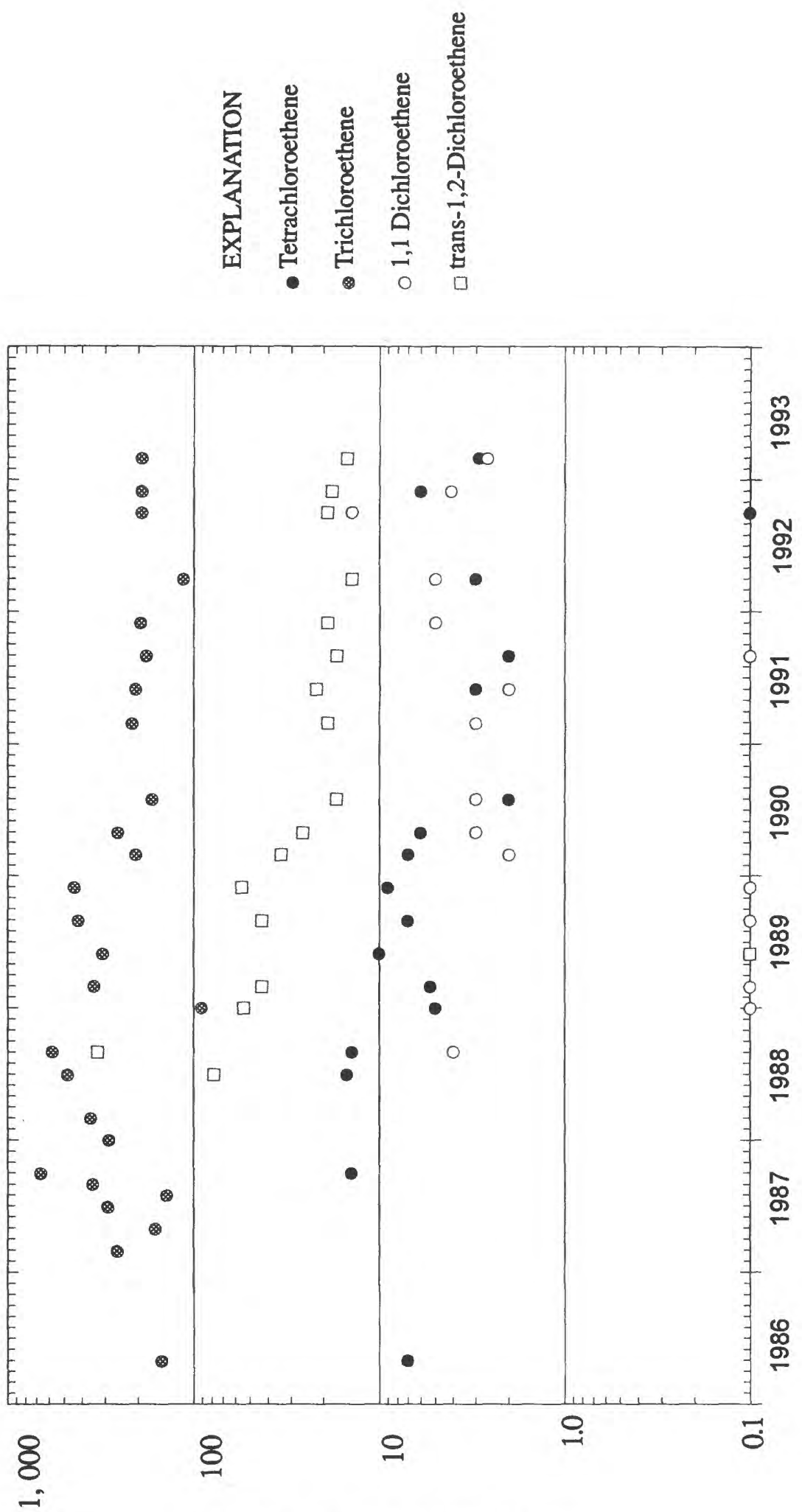

은

응

뜽 뀽

들 등

\&

๖ั ㅇํㅇ

$3 \infty$

도

ต

동 문

ᄃ.

क

\&

으 क

ฮี

읃ㄷㅇ

ช్ర

응으 함

엏ㅎ을

잉

둥

ธ๐ัㅇํㅇ

들 ह듬

중 온

등 ํํㅇ

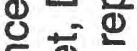

రํㅝㄴㅎㄴ

के ㄴำ 동

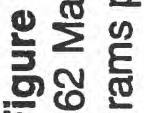

ill 눙

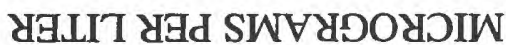

NI 'SGAITVH DINYDYO HO SNOILVYLNGDNOD 

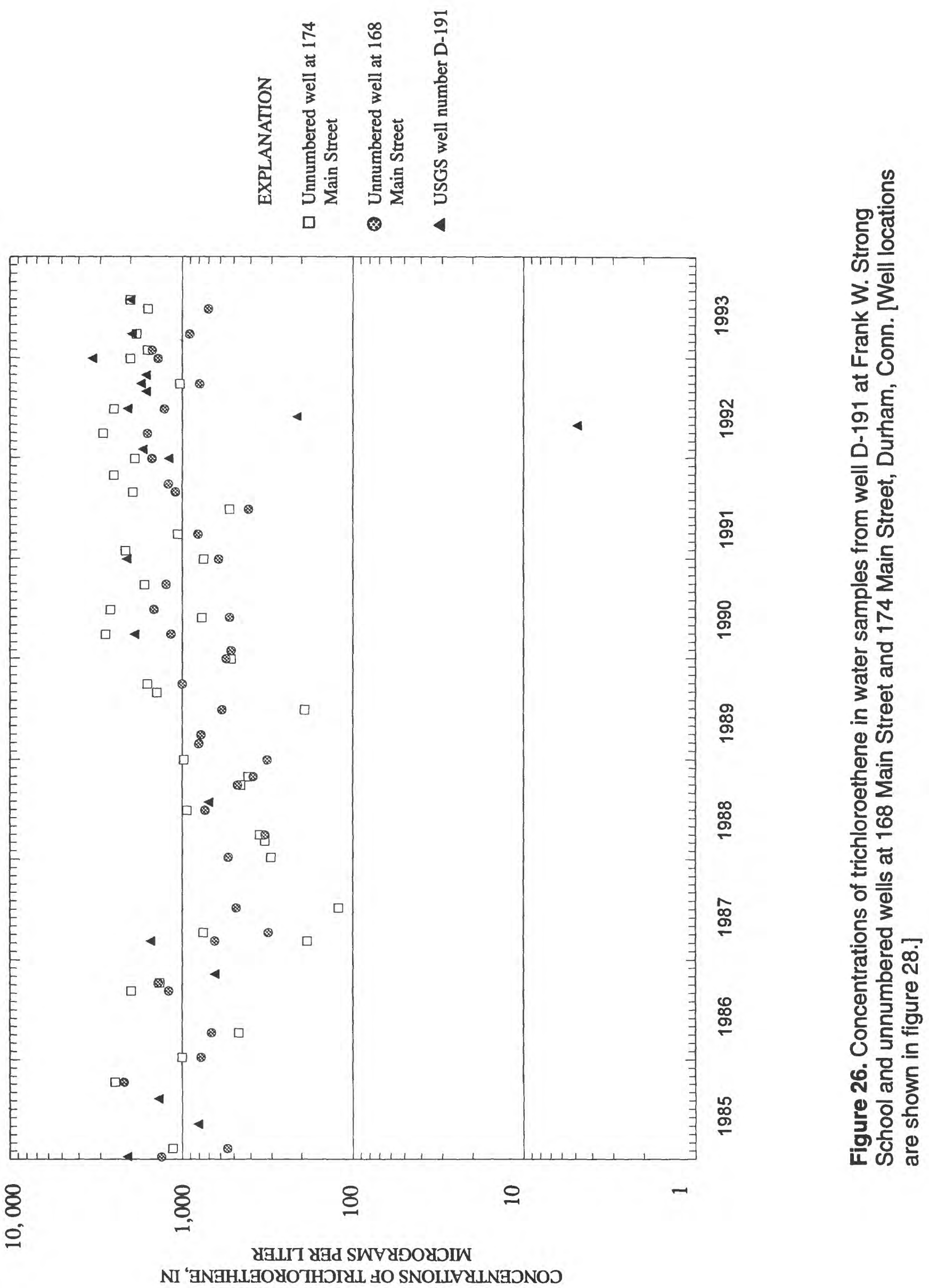

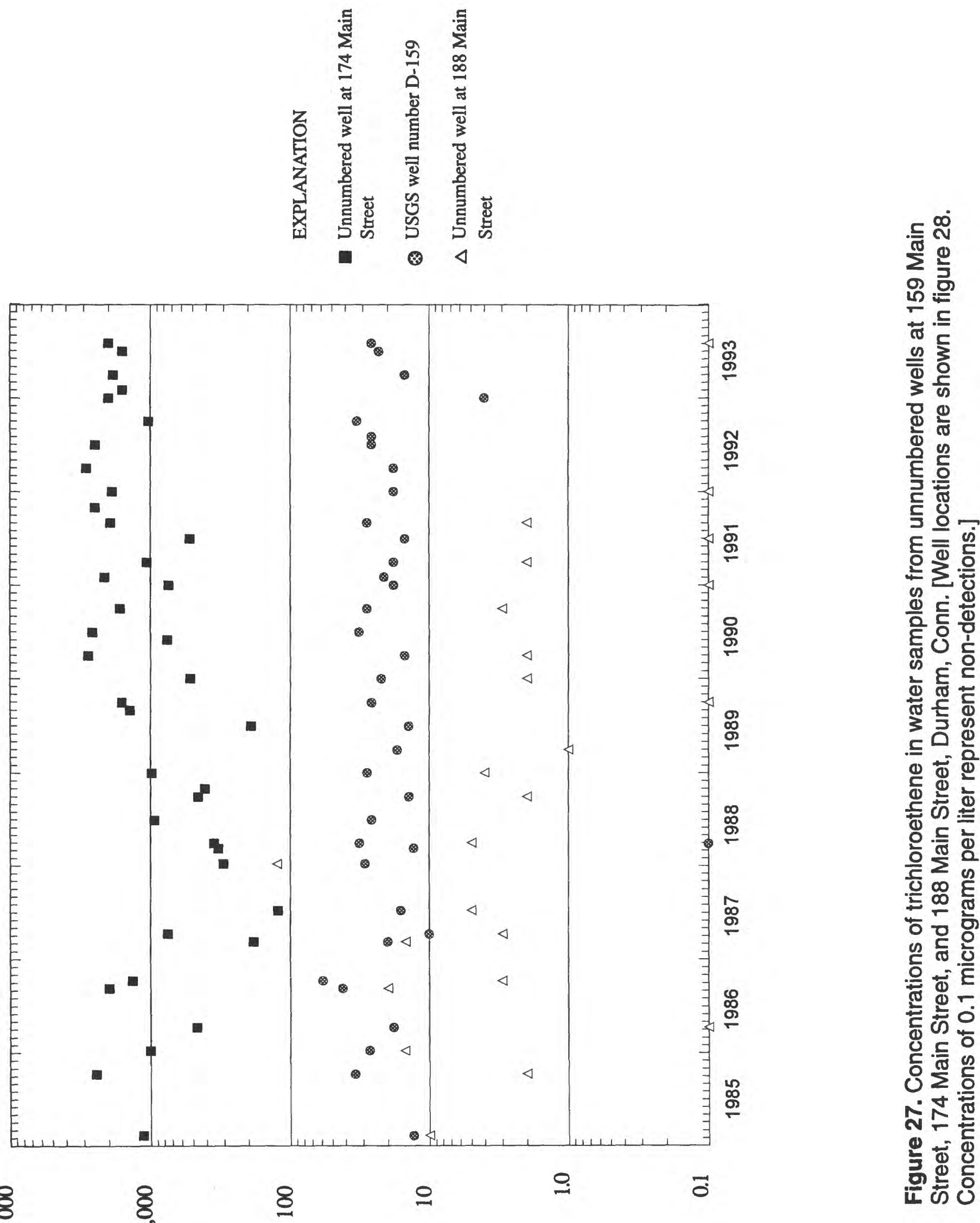


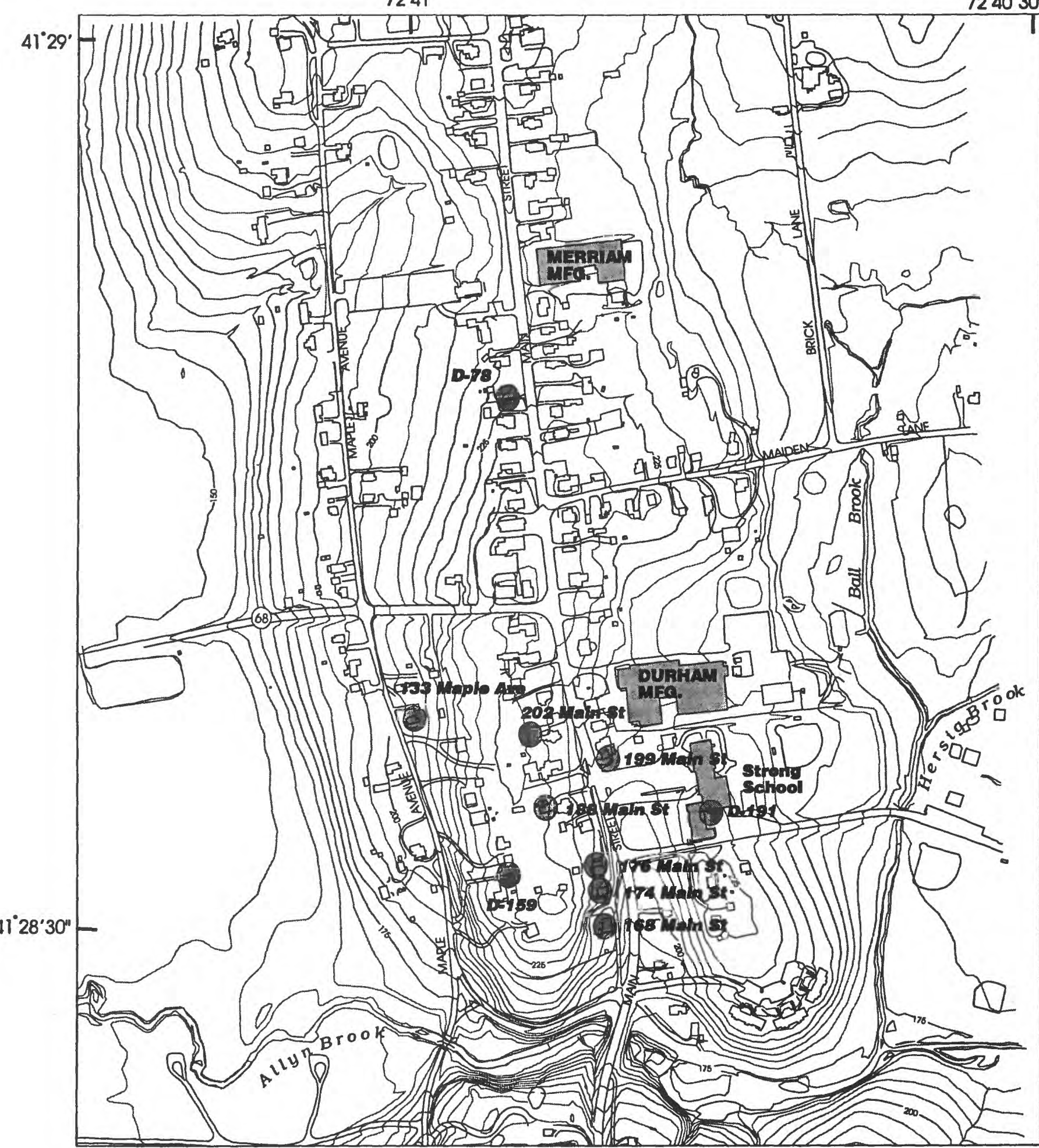

Base from U.S. Army Corps of Englneers, Durham Meadows 1:1,200, 1992

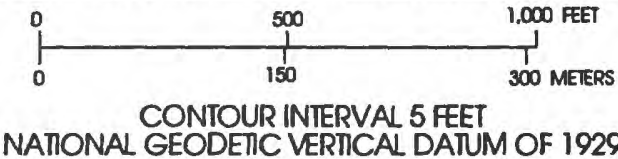

Figure 28. Locations of bedrock wells in the Durham Center area, Durham, Conn., for which long-term water-quality data are shown in figures 24-27. 


\section{CONCEPTUAL MODEL OF THE MOVEMENT AND FATE OF ORGANIC CONTAMINANTS IN GROUND WATER}

The current lack of information about the entry of organic chemicals into the subsurface, the physicochemical properties of the organic chemicals, and the complex geohydrology of the area preclude any reliable diagnosis of the movement and fate of the organic contaminants in the Durham Center area at this time. However, the knowledge of regional geology gained through this study and from earlier investigations (Simpson, 1968a, 1968b and LeTourneau, 1985), the information from hydrogeologic site studies by Leggette, Brashears, and Graham, Inc. (1982) and Roux Associates Inc. (1983, 1988, 1990a), and research on the movement and fate of NAPL's in the subsurface by Schwille (1988) and more recently by others such as Mercer and Cohen (1990); Kueper and others (1992); Bishop and others (1993b); Bourg and others (1993); Burston and others (1993); Lerner and others (1993a);Mouvet and others (1993); Parker and others (1993); and VanderKwaak and Sudicky (1993) allow for development of a credible conceptual model of the movement and fate of organic contaminants in this area. The development of this conceptual model is based on several assumptions:

(1) The principal points of entry to the subsurface of the organic compounds are on the properties occupied by Durham Manufacturing Co. and Merriam Manufacturing $\mathrm{Co}$. The organic compounds were released in accidental spills or leaks or in wastewater discharged to lagoons and subsurface disposal systems. This assumption is consistent with information compiled by the DEP, although other possible sources have been noted.

(2) The organic compounds entered the subsurface and reached the saturated zone in both aqueous and nonaqueous phases.
(3) The till and bedrock have both primary and secondary porosity and permeability. Most water and contaminants move through networks of interconnected openings (fractures and openings along bedding planes) but minor flow and transport take place through the intergranular matrices of the till and sedimentary bedrock.

(4) An unconfined, shallow ground-water flow system is present in most, if not all, of the Durham Center area. The water table in this system is a subdued reflection of the landsurface topography.

(5) The shallow ground-water flow system is superposed on a deeper, intermediate- or regional-scale flow system. Under natural conditions, ground-water flow and contaminant transport in this larger flow system would be westward toward the Coginchaug River and adjacent wetlands.

(6) The bedrock through which ground water flows is a heterogeneous system, where steeply dipping fractures interconnect openings along gently dipping bedding planes or highly fractured beds. Wells also serve to connect different water-yielding zones in the bedrock that might otherwise be hydraulically isolated from each other. The preferential directions of flow and transport coincide with the direction of the strike of a large fault; the dominant directions of the strike of smaller, steeply dipping fractures, some of which may also be faults; and the strike direction of the beds of sedimentary rock.

(7) Hydraulic gradients, and consequently directions and rates of flow and transport within this system, are strongly affected by the widespread cyclical pumpage of ground water.

The block diagram shown in figure 29 is an idealized representation of those parts of the geologic sections B-B' and C-C' (figs. 8 and 11) that transect the Durham Manufacturing Co. and Merriam Manufacturing Co. properties. The block diagram provides a physical 
framework for discussing the conceptual model of the subsurface movement and fate of organic contaminants. The geohydrologic settings at these two manufacturing facilities are similar in many aspects. At Durham Manufacturing Co., an estimated 7 to $18 \mathrm{ft}$ of till overlies sedimentary bedrock. The saturated thickness of this till ranged from 0 to $10 \mathrm{ft}$ in August 1982, shortly after wells D-193 to 199 were constructed (Leggette, Brashears, and Graham, Inc., 1982), and can be several feet greater, as evidenced by the higher water-levels in those wells in March 1983 (Robert LaMonica, Leggette, Brashears, and Graham, Inc., written commun., 1983). The till at Merriam Manufacturing Co. is about 4 to $20 \mathrm{ft}$ thick, and water-level measurements in test pits and shallow borings show that the water table is commonly within the bedrock and the till is either unsaturated or thinly saturated (a saturated zone of up to $3 \mathrm{ft}$ ) (Roux Associates Inc., 1983; 1990a; 1990b). Water-table fluctuations of several feet are common in the till (fig. 9) and the saturated thickness may vary from the observed values.

The conceptual model of contaminant transport and fate and subsequent discussions focus on the type of organic halides that have produced the most significant effect on ground-water quality. These compounds, which include TCE, 1,1,1-TCA, and PCE, and several of their degradation products, are all denser and less viscous than water, are relatively mobile in ground-water flow systems, and commonly degrade into progressively less chlorinated compounds. Less attention is given to the lighter aromatic compounds, such as toluene and benzene, although they have been locally detected in ground-water and samples of soil and glacial sediments. These compounds were detected in relatively few groundwater samples and, except in samples from wells at Merriam Manufacturing Co. (Roux Associates Inc., 1988; Metcalf and Eddy, 1994, appendix F), concentrations generally were much lower than USEPA-established MCL's for drinking water.

The conceptual model considers the movement and fate of the organic compounds first in the unsaturated zone and then in the saturated zone. The entry of the organic compounds from surface spills and leaks or from open pits and subsurface wastewater-disposal facilities is shown in figure 29. In the event of a spill or leak, the organic compound would initially percolate through a layer of disturbed earth or fill (labeled A in fig. 29) that is conceptualized as a porous medium. At Merriam Manufacturing Co. this layer is generally about $3 \mathrm{ft}$ thick, but may locally be thicker at the dry well and leaching field locations described by Roux Associates Inc. (1990a). A comparable average thickness of $3 \mathrm{ft}$ is assumed for this layer at Durham Manufacturing Co. The organic compounds would move downward through this material under the influence of gravity, but part of the mass would be retained as immobile blobs or ganglia within pores and other openings. This residual saturation can be high in porous media for at least some organic halides and increases with decreasing hydraulic conductivity (Schwille, 1988). The retained liquid is subsequently lost as it vaporizes or is slowly dissolved by infiltrating water and transported downward into deeper parts of the unsaturated zone. The vapor can move laterally in all directions thereby transporting some of the contaminants away from the source and may be dissolved in downward percolating precipitation or move upward and escape to the atmosphere.

The next subsurface layer (labeled B in fig. 29) is composed of compact lodgment till that extends down to the sedimentary bedrock (labeled C in fig. 29). The water table is believed always to be located in the till on the Durham Manufacturing Co. property except along the western margin near Route 17 


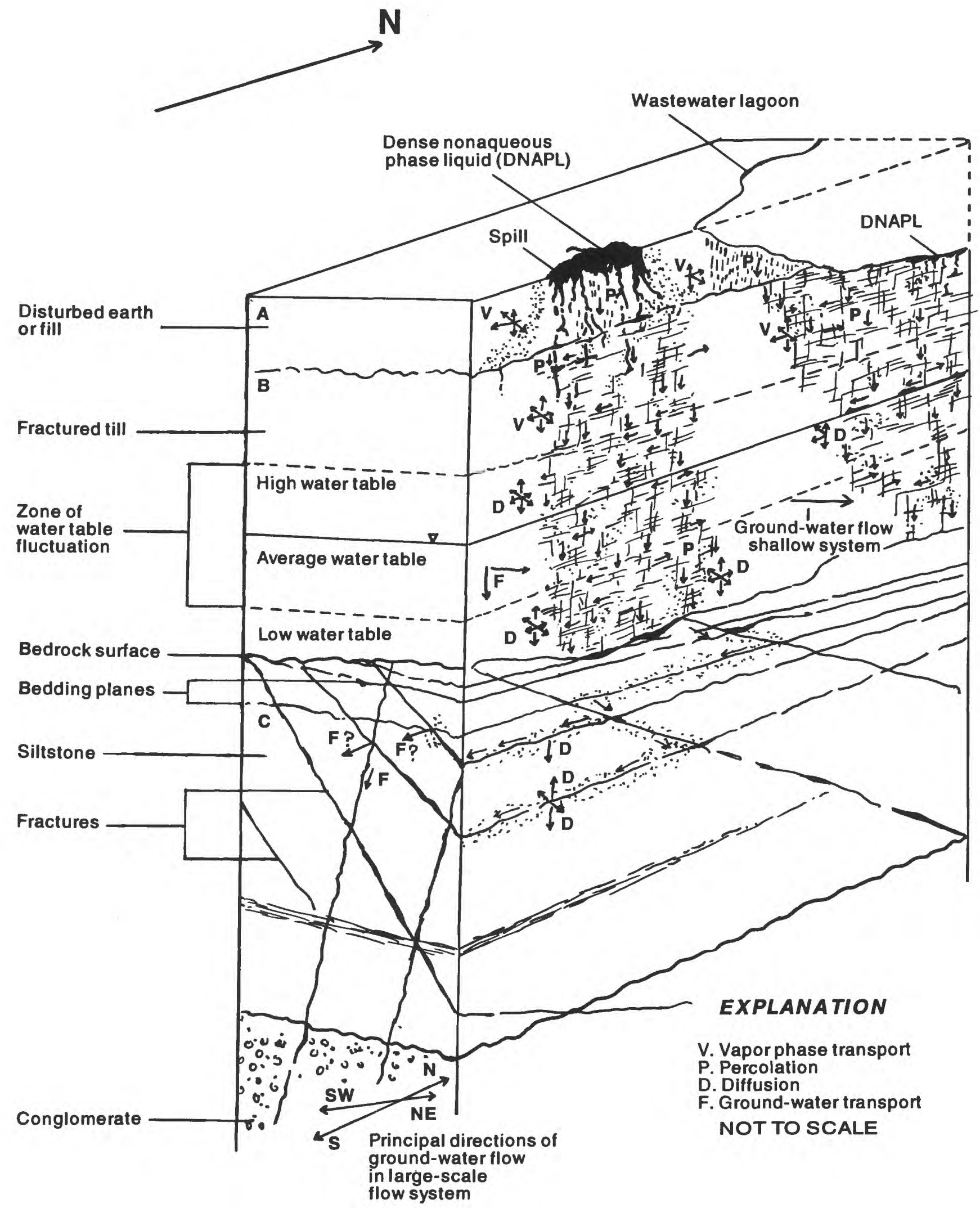

Figure 29. Idealized block diagram representing the physical framework for a conceptual model of contaminant fate and transport at Durham Center, Durham, Conn. 
where it is sometimes in the bedrock. The till beneath most of the Merriam Manufacturing Co. property may be saturated only when the water table is much higher than average--at other times the water table is beneath the bedrock surface except in the wetlands east of the facility. A thick capillary fringe probably exists above the water table at both locations

Any NAPL that percolates through the fill and soil at a spill site or accumulates at the bottom of an open pit or subsurface disposal system could enter the underlying till. Although fracturing has not been reported in till at either manufacturing facility, it is assumed to be present because fractured lodgment till is common in this part of Connecticut. Accordingly, the downward movement of NAPL's or dissolved organic compounds in till is seen as being almost entirely through a network of interconnected, small-aperture fractures and other secondary openings, such as root casts. Some lateral spreading is likely at the top of the till and, where the pores or fractures contain water, the capillary pressure at the entrance to the opening would exceed the entry pressure (Kueper and others, 1992). Movement of NAPL's within the till would be lateral where vertical or steeply dipping fractures intersect the more numerous subhorizontal fractures. Some lateral spreading also takes place at the base of the unsaturated zone (the water table or the top of the capillary fringe, where present).

Some of the NAPL would volatize in the unsaturated zone and the vapor would move away in all directions. Vapor would be preferentially transported through the more permeable fractures or any other type of secondary openings, but some vapor would enter and move through the till matrix. Part of the mass of NAPL is retained at residual saturation levels in the unsaturated, fractured till, but the total amount retained is small in comparison to an equivalent volume of porous media (Schwille, 1988). In the case of DNAPL's, the retention is in the form of films or blebs on the surfaces of the fractures. A fluctuating water table could remove some of the residual DNAPL and transport it deeper into the saturated zone. Transient retention of dissolved organics that are able to enter the low-permeability till matrix would also take place; the effects of this contaminant retardation on the quality of water and glacial sediments are unknown.

Although the movement and fate of LNAPL's are not the focus of this conceptual model, it should be noted that their downward movement ends at the water table or capillary fringe. If the LNAPL is transported that far, it will (1) dissolve in water at the interface between the floating lens of organic liquid and underlying ground water, (2) move as a lens in the direction of the water-table gradient, or (3) vaporize and move into the unsaturated zone.

Below the water table, or capillary fringe, the processes affecting DNAPL movement and retention differ somewhat from what has been described. The migration through fractures in the unsaturated till is shown in figure 29 as being relatively uniform. Below the water table, the migration is conceptualized as less uniform, because of the higher entry pressures required to move DNAPL into a waterfilled fracture and the reduction in the volumes of DNAPL resulting from residual saturation. There is continued dissolution and diffusion into the till matrix. The dissolved mass is transported downgradient with the flowing ground water, resulting in a contaminant plume. At Durham Manufacturing Co., the horizontal gradient in the upper part of the saturated zone is eastward toward Ball Brook. The direction and magnitude of vertical gradients have not been determined, but significant downward gradients are likely where water levels in the bedrock are lower than the water table in till because of pumping bedrock wells.

Most ground water in the till would flow through the fractures; very little would flow through the low-permeability matrix. The dissolved constituents, however, would diffuse 
into or out of the till matrix, depending on their concentrations in water within fractures and water within the adjacent matrix. During a period of several years during which groundwater transport was continuous, a large mass of dissolved organic constituents could have accumulated in the till matrix.

DNAPL'S would also be retained in the saturated zone (residual saturation).

Vaporization would not occur, and any reduction in the mass of DNAPL would result from dissolution and microbial degradation. Microbial degradation would likely be a principal means for the removal of DNAPL's and dissolved-phase organic compounds from the saturated zone.

Whether the organic halides and other organic compounds that are found within the bedrock-aquifer system entered the bedrock in the nonaqueous phase is unknown. The conceptual model considers entry of both aqueous and nonaqueous phase organic compounds into the bedrock. The likelihood of direct entry of nonaqueous phase liquids, particularly DNAPL's, is high in view of several factors that have been already cited, such as the long history of use prior to elimination or reduction of wastewater discharges, the ability of even small volumes of DNAPL's to migrate a great distance through low-porosity material such as fractured till, the relatively shallow depth of the bedrock, and the ability of a fluctuating water table to transport residual DNAPL deeper into the unsaturated zone.

The entry of dissolved organic compounds into the bedrock at the Durham Manufacturing Co. would be controlled by local hydraulic gradients. No data on the direction and magnitude of hydraulic gradients between the saturated till and underlying bedrock are known to have been collected at this locale. However, the pumpage of the Durham Manufacturing Co. supply well (USGS well D-212 in fig. 7) can produce substantial drawdown and water levels in bedrock wells in the area are commonly several feet lower than the bedrock surface (Leggette, Brashears, and Graham, Inc., 1982). This pumpage may locally result in large vertical hydraulic gradients and downward flow between saturated till and bedrock.

Any DNAPL that penetrated the entire thickness of till at this location would likely continue its vertical migration into the underlying fractured shales and sandstones. Lateral flow down the slope of the bedrock surface would continue until a permeable fracture was encountered. Some DNAPL could be retained in pools formed by depressions on the surface of low-permeability bedrock. Once in the bedrock, the DNAPL would move downward through the network of interconnected open fractures and bedding planes until its source was exhausted. The processes affecting movement and retention in the bedrock are similar to those in fractured till. The direction of movement would be largely controlled by the orientation of fractures and bedding planes. The orientations that have already been described include fractures that commonly strike northeastward and dip steeply to the southeast and northwest (figs. 10 and 16); beds that strike NNW and dip gently eastward, and the fault that crosses the Durham Manufacturing Co. property, which strikes northeastward and dips steeply to the northwest.

DNAPL in the bedrock could be retained as blebs or films on fracture surfaces or accumulations trapped in closed-end fractures and bedding-plane openings. The residual DNAPL would be subject to dissolution into ground water flowing through the fracture network and might also be mobilized by fluctuating water levels.

The organic compounds that enter bedrock in the aqueous phase, or are dissolved in ground water after entry, are transported away from the source areas, resulting in a plume (or plumes) of degraded ground water. Most flow of ground water and transport of dissolved 
organic constituents is through the network of interconnected fractures and bedding plane openings and is affected by the degree of connectivity of the openings and the variation in aperture along fracture or bedding planes. Minor flow and transport take place through the rock matrix, particularly through the matrix of more permeable sandstone layers. As in the case of till, dissolved organic compounds diffuse into the rock matrix from the ground water flowing through open fractures and bedding planes. Diffusion may greatly retard the movement of the mass of dissolved organic constituents through the bedrock-aquifer system, particularly in areas where the rock has high intergranular (matrix) porosity and the ground water in the fractures has high concentrations of organic compounds. This diffusive interchange of organic halides between fractures and the rock matrix has been identified by Bishop and others (1993a) as an important process in similar sedimentary rocks that are contaminated with TCE. The net effect is to extend the length of time during which contaminated ground water is present. Sorption of dissolved organics on carbonaceous material present in gray and black siltstone and shale units is also possible, but sorption would be minimal in the other sedimentary rocks (Bourg and others, 1993).

Cyclical pumping of wells at Durham Manufacturing Co. and Merriam Manufacturing Co. results in the flow of ground water toward these pumping centers. At other times, when the plants are not operating, the pumping of domestic wells along Main St. and Maple Ave. affects the pattern of ground-water flow in the Durham Center area. The predominant northeast-southwest orientation of fracture zones, the north to slightly west of north strike of bedding and some fractures, together with the pumping-induced gradients, have apparently resulted in preferential movement of dissolved contaminants to the southwest and south of the source areas. The water-quality data indicate that little transport occurs to the west, which under natural conditions is believed to be the general direction of groundwater flow in the regional bedrock flow system. Degradation of at least some of the organic halides in the ground water is shown by the presence of simpler (less chlorinated) compounds, such as cis-1,2-DCE. In the conceptual model, microbial degradation (biodegradation) is considered the most likely mechanism for long-term attenuation of the organic contaminants. The rates at which attenuation would occur and its effect on the potability of the water are unknown.

The conceptual model described herein is a general and, to some extent, speculative one. An improved understanding of waterquality degradation in the area would require additional data and new investigative techniques. Additional comprehensive water-quality analyses of samples from existing wells, including analyses for organic halides that are degradation products, and effective and welldocumented sampling protocols and qualityassurance procedures are the most essential requirement for assessing the magnitude of contamination. Data on the depths and open intervals of all monitored wells are also needed.

Other techniques or information that could provide additional insight on the threedimensional distribution of organic halides and the complex hydrogeology controlling their movement include the following:

(1) Collection and analysis of continuous core samples of till and bedrock, particularly in areas where contaminants may have been introduced into the subsurface. Analyses of pore fluids from these cores would provide information on the presence or absence of DNAPL's, concentrations of dissolved organic compounds in water from the till and rock matrices, and the importance of the process of diffusion in retarding contaminant transport. The core samples also could be used to determine intergranular (matrix) porosity and hydraulic conductivity. 
(2) Additional borehole-geophysical surveys, particularly acoustic-televiewer logs and heat-pulse flowmeter measurements made under ambient and pumped conditions. Other newer borehole-logging techniques, such as borehole radar (Olsson and others, 1992) and borehole seismic tomography (Wright and others, in press), can determine the extent and interconnection of fractures over relatively large distances (greater than $100 \mathrm{ft}$ in some settings). These logs, together with enhanced television images, would allow refinement and extension of bedrock lithologic and structural interpretations.

(3) Accurate head measurements to define natural and induced vertical and horizontal gradients in the till and bedrock. These measurements would require temporary cessation of ground-water withdrawals from the bedrock and (or) controlling withdrawal rates, which would be difficult. Delineation of head changes would also require use of packers to isolate zones within well bores.

(4) Hydraulic tests and forced-gradient tracer tests to determine bulk permeability of the bedrock, the hydraulic conductivity of individual fractures or fracture zones, and the interconnection of fractures. Cross-borehole flow tests together with borehole geophysics are reportedly effective in identifying hydraulic connections between fracture zones (Paillet, 1993).

(5) Collection and analysis of water samples from isolated zones of water inflow and outflow in bedrock wells. The resulting information would help define the vertical distribution of contaminants in the bedrock-aquifer system.

Much of the needed information can be obtained only by drilling additional holes, which could conceivably facilitate an increase in the extent of contamination of the bedrockaquifer system. A sequential procedure for investigating contamination by organic halides in areas geohydrologically similar to Durham Center has been recommended by Lerner and others (1993b). This procedure attempts to minimize the spread of contamination by initially drilling outside of contaminated areas. Within or near to contaminated areas, drilling methods that prevent the possibility of crosscontamination are used. One such method involves incremental drilling that stops at each low-permeability zone. Casing is extended to the low permeability zone; the basal part of the hole is then plugged and drilling is continued throughout the plug. 


\section{SUMMARY AND CONCLUSIONS}

Widespread and persistent contamination of ground water beneath Durham Center is well documented by analytical data. The principal contaminants are organic halides, most commonly TCE, 1,1,1-TCA, and PCE.

Organic halides in water from the sedimentary bedrock aquifer at concentrations that exceed the U.S. Environmental Protection Agency maximum contaminant levels for drinking water are a major environmental concern. Less extensive contamination of surface water, soil, and glacial sediments also has been observed. Two manufacturing companies, in the northern and southern parts of this area, were identified by the Department of Environmental Protection in 1982 as the principal sources of the organic contaminants, although other possible sources have been noted. Discharge of wastewater into subsurface disposal systems has undoubtedly redistributed organic contaminants at some locations.

The regional and local geohydrology of the area is highly complex with respect to the lithology, structural features, hydraulic properties, and the flow of ground water in the unconsolidated glacial deposits and sedimentary rocks. Compact lodgment till, 5 to $30 \mathrm{ft}$ thick, overlies the bedrock at Durham Center, whereas stratified-drift deposits are present only in valleys to the east and west. The till is believed to be fractured, on the basis of observations at nearby exposures. The bedrock consists of a sequence of layered sedimentary rocks; highlands to the east of Durham Center are underlain by crystalline rocks.

The sedimentary bedrock is lithologically heterogeneous and is composed mainly of red fluvial sandstone, siltstone, and conglomerate; locally interbedded with gray lacustrine sandstone and black shale. The sandstone units are largely composed of quartz, feldspar, and metamorphic rock fragments with albite and carbonate cements. Organic carbon is present in the lacustrine units, where it reportedly ranges from 1 to 4 percent by weight.

The sedimentary rocks have a generally northward strike and a gentle eastward dip. At least one high-angle normal fault cuts the bedrock beneath Durham Center. This fault, termed the Ball Brook fault in this report, strikes northeast and dips to the northwest. The presence of this fault, initially inferred from regional geologic information, has been corroborated in this study by surface-geophysical surveys. Additional faults may also cut the rocks in this area but have not been confirmed by geophysical methods. Acoustic-televiewer logs, measurements made at outcrops near Durham Center, and azimuthal, square-array dc-resistivity soundings indicate that fractures in these rocks have a dominant northeast strike and dip steeply to the northwest and southeast.

Recharge to till and bedrock is estimated to average about $8 \mathrm{in} / \mathrm{yr}$ on the basis of studies elsewhere in Connecticut. Both till and sedimentary bedrock are dual-porosity, dual-permeability media; most flow is through networks of interconnected fractures but some flow is also through the granular matrix of these materials. The hydraulic conductivity of the bulk mass of till is generally a few tenths of a foot per day to about $2.5 \mathrm{ft} / \mathrm{d}$, but the hydraulic conductivity of the till matrix is one to two orders of magnitude less. Average total porosity of the till matrix is about 25 percent; fracture porosity is currently unknown but is probably small (less than 1 percent). Transmissivity and storativity of the sedimentary bedrock have been estimated at many well sites, based on analysis of aquifer tests and specificcapacity data. These analyses assume artesian conditions and result in estimated transmissivities that range from less than $1 \mathrm{ft}^{2} / \mathrm{d}$ to about $1,700 \mathrm{ft}^{2} / \mathrm{d}$ and estimated storativities that range from $10^{-5}$ to $10^{-4}$. The accuracy of these estimates is uncertain, largely because field conditions failed to meet assumptions inherent in the methods of analyses. The intergranular porosity is estimated to average about 5 per- 
cent in the sandstones and siltstones on the basis of measurements made elsewhere in Connecticut. The fracture porosities of 1.1 and 2.7 percent were estimated from square-array dc-resistivity sounding data but these values may be too high because the analytical method assumes all anisotropy is caused by fractures.

A local ground-water-flow system is in the upper part of the saturated zone with a water-table configuration that is generally undefined but is likely a subdued reflection of the topography. Ground-water discharge from this flow system, under natural conditions, is to adjacent streams such as Ball Brook, Hersig Brook, and Allyn Brook. Water-level observations made at many locations over several decades indicate that the depth to the water table may vary from less than $3 \mathrm{ft}$ to $26 \mathrm{ft}$, and the water table may be in the bedrock at some sites.

A larger-scale ground-water-flow system in the bedrock is evidenced by the transport of organic contaminants beneath topographic highs that define surface-water drainage divides in the Allyn Brook basin. Groundwater flow in the bedrock, however, is poorly understood, and the bedrock shows features of both a single unconfined aquifer and a multiunit artesian or leaky-aquifer system. The numerous bedrock wells have changed the natural flow system by altering the direction and magnitude of hydraulic gradients and connecting fractures that were hydraulically isolated. Neither the details of the ground-water flow paths nor the nature of the aquifer system can be resolved without additional data.

The contaminants at Durham Center are principally organic halides that are volatile, denser than water, and only slightly soluble in water. These compounds are likely to have entered the subsurface as DNAPL's. Analytical data currently available are insufficient for a comprehensive assessment of water quality. Data on surface-water quality are sparse, but recent (1993) analysis of samples collected during a low-flow period indicate that degrada- tion of streams by organic halides is minimal. Most ground-water analyses are insufficient to evaluate water quality because concentrations of only a few compounds, primarily TCE, 1,1,1-TCA, and PCE, are reported. These data show that concentrations of organic halides in ground water from bedrock can differ considerably from one place to another as well as with time. Several general patterns are present, but at most wells, the concentrations show a relatively narrow range of fluctuation (one or two orders of magnitude) during periods of several years. Some degradation to less chlorinated compounds has also taken place as evidenced by the presence of compounds such as 1,1 DCE.

The geohydrologic and water-quality information collected at Durham Center, together with recent research on the subsurface transfer and fate of organic halides in ground water, have been used to develop a conceptual model of the transport and fate of organic contaminants in this area. Several conclusions, some of which are speculative, have been derived from this conceptual model. These conclusions are as follows:

(1) The principal ground-water contaminants are dense, low-solubility compounds. The documented long period of use and past handling and disposal practices at Durham Manufacturing Co. and Merriam Manufacturing Co., and relatively high concentrations in some samples of ground water from shallow wells, make it likely that DNAPL's were, and may still be, present in subsurface materials, although none have been observed.

(2) The persistence of high concentrations of organic halides in ground water from several bedrock wells located near purported sources indicates that there is some mechanism for contaminant retention. This mechanism could be residual saturation by DNAPL's in open pores in the upper part of the till, in fracture planes in deeper parts of the till, or in fracture planes in the bedrock; diffusion into the intergranular pores of the till and (or) bedrock; 
or temporary sorption on carbonaceous material and mineral surfaces. Residual saturation of till or bedrock has not been identified near any of the source areas but the possibility cannot be overlooked. Detection of DNAPL residual saturation in the fractured till or fractured bedrock could be difficult. The most probable mechanism for retaining dissolved organic contaminants in the saturated till or bedrock is matrix diffusion. The significance of this process in retarding contaminant movement has been identified in several of the studies cited in this report. Diffusion into the till or rock matrix, particularly into the more porous, coarse-grained layers of bedrock, could likewise result in significant retention and retardation of dissolved-phase constituents at Durham Center.

(3) An alternative explanation for the persistence of high concentrations of organic halides in ground water--namely, continued release from known or unknown sources--is possible. The water in the unlined, artificial pond east of Durham Manufacturing Co. reportedly had low concentrations of organic halides that could be transported into the subsurface. In the nonaqueous phase, these compounds could sink, accumulate on the pond bottom, and then enter the subsurface as DNAPL's.
(4) The transport of dissolved organic halides is affected by the structural features of the sedimentary bedrock. Preferential movement to the south and southwest of the purported source areas is coincident with the strike direction of the Ball Brook fault, the dominant and secondary strike directions of high-angle fractures, and the general strike direction of bedding. On the smaller scale, evidence indicates that ground water and associated dissolved contaminants flow through both the high-angle fractures and openings along gently dipping bedding planes.

(5) The flow of ground water and transport of dissolved organic compounds have also been affected by pumping from the numerous bedrock wells in this area. Results of aquifer tests indicate that some wells are hydraulically connected by the fracture network whereas others are not. Wells serve to connect fractures that were formerly isolated, as evidenced by heat-pulse flowmeter measurements made under ambient conditions. Pumpage also affects ground-water flow and contaminant transport by creating or altering hydraulic gradients. Large withdrawals, such as at Durham Manufacturing Co., can affect hydraulic head over distances of several hundred feet. 


\section{REFERENCES}

Acton, D.W., and Barker, J.F., 1992, In situ biodegradation potential of aromatic hydrocarbons in anaerobic groundwaters: Journal of Contaminant Hydrogeology, v. 9, p. 325-352.

Bingham, J.W., Paine, F.D., and Weiss, L.A., 1975, Hydrogeologic data for the lower Connecticut River basin, Connecticut: Connecticut Water Resources Bulletin 30, $59 \mathrm{p}$.

Bishop, P.K., Jakobsen, Rasmus, Gosk, Edmund, Lerner, D.N., and Burston, M.W., 1993a, Investigation of a solvent polluted industrial site on a deep sandstonemudstone sequence in the UK, Part 1. Site description and groundwater flow: Journal of Hydrology, v. 149, p. 209-229.

Bishop, P.K., Lerner, D.N., Jakobsen, Rasmus, Gosk, Edmund, Burston, M.W., and Chen, T., 1993b, Investigation of a solvent polluted industrial site on a deep sandstone-mudstone sequence in the UK, Part 2. Contaminant sources, distributions, transport and retardation: Journal of Hydrology, v. 149, p. 231-256.

Bourg, A.C.M., Degranges, Philippe, Mouvet, Christophe, and Sauty, J. P., 1993, Migration of chlorinated hydrocarbon solvents through Coventry sandstone rock columns: Journal of Hydrology, v. 149, p. 183-207.

Brown, J.S., 1928, Ground water in the New Haven area, Connecticut: U.S. Geological Survey Water-Supply Paper 540, 206 p.

Brown, R.H., 1963, Estimating the transmissibility of an artesian aquifer from the specific capacity of a well, in Bentall, Ray, compiler, Methods of determining permeability, transmissibility, and drawdown: U.S. Geological Survey WaterSupply Paper 1536-I, p. 336-338.
Brumbach, J.J., 1965, The climate of Connecticut: Connecticut Geological and Natural History Survey Bulletin 99, 215 p.

Buchanan, T.J., and Somers, W.P., 1969, Discharge measurements at gaging stations: U.S. Geological Survey Techniques of Water-Resources Investigations, book 3, chap. A8, $65 \mathrm{p}$.

Burston, M.W., Nazari, M.M., Bishop, P.K., and Lerner, D.N., 1993, Pollution in groundwater in the Coventry region (UK) by chlorinated hydrocarbon solvents: Journal of Hydrology, v. 149, p. 137-161.

Carter, R.W., and Davidian, Jacob, 1968, General procedure for gaging streams: U.S. Geological Survey Techniques of Water-Resources Investigations, book 3 , chap. A6, 13 p.

Cervione, M.A., Jr., Mazzaferro, D.L., and Melvin, R.L., 1972, Water resources inventory of Connecticut, part 6, upper Housatonic River basin: Connecticut Water Resources Bulletin 21, 84 p.

Cervione, M.A., Jr., Melvin, R.L., and Cyr, K.A., 1982, A method for estimating the 7day, 10-year low flow of streams in Connecticut: Connecticut Water Resources Bulletin 34, $17 \mathrm{p}$.

Cooper, H.H., and Jacob, C.E., 1946, A generalized graphical method for evaluating formation constants and summarizing well field history: American Geophysical Union Transactions, v. 27, p. 526-534.

Darboux-Afouda, R., and Louis, P., 1989, Contribution des mesures de l'anisotropic electrique la recherche des aquifres de fracture en milieu cristallin au Benin: Geophysical Prospecting, v. 37, p. 91-105.

D'Astous, A.Y., Ruland, W.W., Bruce, J.R.G., Cherry, J.A., And Gillham, R.W., 1989, Fracture effects in the shallow groundwater zone in weathered Sarniaarea clay: Canadian Geotechnical Journal, v. 26 , no. 1 , p. $43-56$. 
Eaton, G.P. and Rosenfeld, J.L., 1960, Gravimetric and structural investigations in central Connecticut: International Geological Congress, 21st., Report, part 2, Copenhagen, Denmark, p. 168-178.

Ferris, J.G., Knowles, D.B., Brown, R.H., and Stallman, R.W., 1962, Theory of aquifer tests: U.S. Geological Survey WaterSupply Paper 1536-E, p. 69-174.

Fetter, C.W., 1993, Contaminant hydrogeology: New York, Macmillan Publishing Co., 458 p.

Grady, S.J., 1994, Effects of land use on quality of water in stratified-drift aquifers in Connecticut-Chapter B, Analysis of nonpoint-source ground-water contamination in relation to land use: U.S. Geological Survey Water-Supply Paper 2381, 56 p.

Gregory, H.E., 1909, Underground water resources of Connecticut, with a study of the occurrence of water in crystalline rocks, by E.E. Ellis: U.S. Geological Survey Water-Supply Paper 232, 200 p.

Grisak, G.E., Cherry, J.A., Vonhof, J.A., And Blumele, J.P., 1976, Hydrogeologic and hydrochemical properties of fractured till in the Interior Plains region, in Leggett, R.F., ed., Proceedings of conference on glacial till: Royal Society of Canada Special Publication 12, p. 304-335.

Haeni, F.P., and Anderson, H.R., 1980, Hydrogeologic data for south-central Connecticut: Connecticut Water Resources Bulletin 32, $43 \mathrm{p}$.

Haley and Aldrich Inc., 1992, Remedial investigation (soil-gas survey), Merriam Manufacturing Co., Durham, Connecticut:

Hartford Courant, 1983, Bottled water no luxury in Durham: Hartford Courant, v. CXCVI, no. 13, p. E6.

Hawley, G.G., 1977, The condensed chemical dictionary (9th ed.): New York, Van Nostrand Reinhold Company, 957 p.
Hearst, J.R., and Nelson, P.H., 1985, Well logging for physical properties: New York, McGraw-Hill Book Co., 576 p.

Horne, G.S., McDonald, N.G., LeTourneau, P.M., and deBoer, J.Z., 1993, Paleoenvironmental traverse across the early Mesozoic Hartford rift basin, in Cheney, J.T., and Hepburn, J.C., eds., Field trip guidebook for the northeastern United States, v. 2; 1993 Geological Society of America Annual Meeting, Boston, Mass., October 25-28, 1993: Amherst, Mass., University of Massachusetts Department of Geology and Geography Contribution No. 67, p. P-1 to P-26.

Hubert, J.F., Feshbach-Meriney, P.E., and Smith, M.A., 1992, The Triassic-Jurassic Hartford rift basin, Connecticut and Massachusetts--Evolution, sandstone diagenesis, and hydrocarbon history: American Association of Petroleum Geologists Bulletin, v. 76, no. 11 , p. 1710-1734.

Hubert, J.F., Reed, A.A., Dowdall, W.L., and Gilchrist, J.M., 1978, Guide to the redbeds of central Connecticut in 1978 field trip, eastern section of the Society of Economic Paleontologists and Mineralogists:

Amherst, Mass., University of Massachusetts Department of Geology and Geography Contribution 32, $129 \mathrm{p}$.

Hvorslev, M.J., 1951, Time lag and soil permeability in ground-water observations: U.S. Army Corps of Engineers Waterways Experiment Station Bulletin 36, $50 \mathrm{p}$.

Keller, C.K., van der Kamp, Garth, and Cherry, J.A., 1989, A multiscale study of the permeability of a thick clayey till: Water Resources Research, v. 25, no. 11, p. 2299-2317.

Keys, W.S., 1990, Borehole geophysics applied to ground-water investigations: U.S. Geological Survey Techniques of Water-Resources Investigations, book 2, chap. E2, 150 p. 
Klimenok, John, Jr., 1989, A hydrogeological study of the town of Durham, Connecticut: Middletown, Conn., Wesleyan University, unpublished MA thesis, $288 \mathrm{p}$.

Kruseman, G.P., and deRidder, N.A., 1991, Analysis and evaluation of pumping test data (2nd ed.): International Institute for Land Reclamation and Improvement Publication 47, $377 \mathrm{p}$.

Kueper, B.H., Haase, C.S., and King, H.L., 1992, Leakage of dense nonaqueous phase liquids from waste impoundments constructed in fractured rock and clay--theory and case history: Canadian Geotechnical Journal, v. 29, no. 2, p. 234-244.

Lane, J.W., Jr., Haeni, F.P., and Watson, W.M., 1995, Use of a square-array directcurrent resistivity method to detect fractures in crystalline bedrock in New Hampshire: Ground Water, v. 33, no. 3, p. 476-485.

Leggette, Brashears, and Graham, Inc., 1982, Ground-water quality investigation Durham Manufacturing Company, Durham, Connecticut: Danbury, Conn., 38 p., 2 app.

Lerner, D.N., Burston, M.W., and Bishop, P.K., 1993a, Hydrogeology of the Coventry region (UK)--An urbanized, multilayer, dual porosity aquifer system: Journal of Hydrology, v. 149, p. 111-135.

Lerner, D.N., Gosk, Edmund, Bourg, A.C.M., Bishop, P.K., Burston, M.W., Mouvet, Christophe, Degranges, Philippe, and Jakobsen, Rasmus, 1993b, Postscript-Summary of the Coventry groundwater investigation and implications for the future: Journal of Hydrology, v. 149, p. 257-272.

LeTourneau, P.M., 1985, The sedimentology and stratigraphy of the Lower Jurassic Portland Formation, central Connecticut: Middletown, Conn., Wesleyan University, unpublished MA thesis, $247 \mathrm{p}$.
LeTourneau, P.M., and McDonald, N.G., 1985 , The sedimentology, stratigraphy and paleontology of the Lower Jurassic Portland Formation, Hartford Basin, central Connecticut, in Tracy, R.J. ed., Guidebook for fieldtrips in Connecticut and adjacent areas of New York and Rhode Island; New England Intercollegiate Geological Conference, 77th Annual meeting, New Haven, Conn.: Connecticut State Geological and Natural History Survey Guidebook, no. 6, trip B-7, p. 353-391.

Mazzaferro, D.L., Handman, E.H., and Thomas, M.P., 1979, Water resources inventory of Connecticut, part 8, Quinnipiac River basin: Connecticut Water Resources Bulletin 27, 88 p.

McNeill, J.D., and Labson, V.F., 1987, Geological mapping using VLF radio fields, in Nabighian, M.N., (ed.), Electromagnetic methods in applied geophysics--Applications Part A and Part B: Tulsa, Oklahoma, Society of Exploration Geophysicists, p. $521-640$

Melvin, R.L., 1985, Connecticut groundwater resources, in U.S. Geological Survey, National Water Summary 1984-Hydrologic events, selected water-quality trends and ground-water resources: U.S. Geological Survey Water-Supply Paper 2275, p. 161-166.

Melvin, R.L., deLima, V.A., and Stone, B.D., 1992a, Stratigraphy and hydraulic properties of tills in southern New England: U.S. Geological Survey Open-File Report 91$481,53 \mathrm{p}$.

Melvin, R.L., Stone, B.D., Stone, J.R., and Trask, N.J., 1992b, Hydrogeology of thick till deposits in Connecticut: U.S. Geological Survey Open-File Report 92-43, 43 p.

Mercer, J.W., and Cohen, R.M., 1990, A review of immiscible fluids in the subsurface--Properties, models, characterization, and remediation: Journal of Contaminant Hydrology, v. 6, no. 2, p. 107-163. 
Metcalf and Eddy, Inc., 1994, Data summary report, Start initiative, Durham Meadows, Durham, Connecticut: 92 p., 12 appendixes (A-L).

Michalski, Andrew, 1990, Hydrogeology of the Brunswick (Passaic) Formation and implications for ground water monitoring practice: Ground Water Monitoring Review, v. 10, no. 4.

Mouvet, Christophe, Barberis, Delphine, and Bourg, A.C.M., 1993, Adsorption isotherms of tri- and tetrachloroethylene by various natural solids: Journal of Hydrology, v. 149, p. 163-182.

National Oceanic and Atmospheric Administration, 1992, Climatological data annual summary, New England, 1991: Asheville, N.C., v. 13, no. 13, 51 p.

Newell, C.J., and Ross, R.R., 1992, Estimating potential for occurrence of DNAPL at Superfund sites: U.S. Environmental Protection Agency, Office of Solid Waste and Emergency Response, Publication 9355.4-O7FS, 9 p.

New York Times, 1984, Tainted wells lead to tax relief: The New York Times, v. 133, March 4, 1984, section 11, p. 1.

Olsson, Olle; Andersson, Per; Carlsten, Seje; Falk, Lars; Niva, Borge; and Sandberg, Eric, 1992, Fracture characterization in crystalline rock by borehole radar, in Pilon, J. ed., Ground penetrating radar: Geological Survey of Canada Paper 90-4, p. 139-150.

Paillet, F.L., 1985, Geophysical well log data for study of water flow in fractures in bedrock near Mirror Lake, West Thornton, New Hampshire: U.S. Geological Survey Open-File Report 85-340, 27 p.

1993, Using borehole geophysics and cross-borehole testing to define hydraulic connections between fracture zones in bedrock aquifers: Journal of Applied Geophysics, v. 30, p. 261-279.
Papadopolous, I.S., Bredehoeft, J.D., and Cooper, H.H., Jr., 1973, On the analysis of "slug test" data: Water Resources Research, v. 9, no. 4, p. 1087-1089.

Parker, B.L., Cherry, J.A., Gillham, R.W., and Broholm, M.M., 1993, Field and laboratory evidence of diffusive masstransfer rates from immiscible-phase organic liquids in clay Quaternary deposits [abs]: Geological Society of America 1993, annual meeting program with abstracts, p. A-258.

Parker, S.P., ed., 1992, McGraw-Hill encyclopedia of chemistry, 2d ed.: New York, McGraw-Hill Book Company, 1236 p.

Rantz, S.E., 1982, Measurement and computation of streamflow--volume 1. Measurement of stage and discharge: U.S. Geological Survey Water-Supply Paper 2175, $284 \mathrm{p}$.

Rodgers, John, compiler, 1985, Bedrock geological map of Connecticut: Connecticut Geological and Natural History Survey, Natural Resources Atlas Series Map, 2 sheets, scale 1:125,000.

Roux Associates Inc., 1983, Ground-water investigation, Merriam Manufacturing Company, Durham, Connecticut: Huntington, N.Y., 20 p., 2 appendixes.

----- 1988, Site investigation, Merriam Manufacturing Company, Durham, Connecticut: East Granby, Conn., 60 p., 4 appendixes.

---- 1990a, Phase II site investigation report, Merriam Manufacturing Company, Durham, Connecticut: East Granby, Conn., 73 p., 9 appendixes.

1990b, Phase II site investigation report, Merriam Manufacturing Company, Durham, Connecticut; volume II appendixes: East Granby, Conn., 140 p. 
---- 1990c, Addendum to the Phase II site investigation report, Merriam Manufacturing Company, Durham, Connecticut: East Granby, Conn., 26 p., 5 app.

---- 1990d, Proposed work plan for additional investigation, Merriam Manufacturing Company, Durham, Connecticut: East Granby, Conn., 28 p., 2 app.

1991a, Proposed water-quality screening program, Merriam Manufacturing Company, Durham, Connecticut: East Granby, Conn., 30 p.

-.-- 1991b, Addendum to the proposed workplan for additional investigation (Task 3: Ground-water investigation), Merriam Manufacturing Company, 124 Main Street, Durham, Connecticut: East Granby, Conn., variously paginated.

Roy F. Weston Inc., 1989, Removal program site investigation for Durham Meadows site, Durham, Connecticut: Prepared for U.S. Environmental Protection Agency Region 1, Contract no. 68-01-7367, Lexington, Mass., 19 p., 7 app.

Schwille, Friedrich, 1988, Dense chlorinated solvents in porous and fractured media: Chelsea, Mich., Lewis Publishers, Inc., $146 \mathrm{p}$.

Simpson, H.E., 1966, Bedrock geologic map of the New Britain quadrangle, Connecticut: U.S. Geological Survey Geologic Quadrangle Map GQ-494, scale 1:24,000.

-.--- 1968a, Preliminary bedrock geologic map of part of the Durham quadrangle, Connecticut: U.S. Geological Survey Open-File Report 69-257, 3 sheets, scale $1: 24,000$.

$1968 \mathrm{~b}$, Surficial geologic map of the Durham quadrangle, Middlesex and New Haven counties, Connecticut: U.S. Geological Survey Geologic Quadrangle Map GQ-756, scale 1:24,000.
Stephenson, D.A., Fleming, A.H., And Mickelson, D.M., 1988, Glacial deposits, in Back, William, Rosenshein, J.S., and Seaber, P.R., eds., Hydrogeology: Boulder, Colo., Geological Society of America, The Geology of North America, v. O-2, p. 301-314.

Stone, J.R., Schafer, J.P., London, E.H., and Thompson, W.B., 1992, Surficial materials map of Connecticut: U.S. Geological Survey Special Map, 2 sheets, scale 1:125,000.

Telford, W.M., King, W.F., and Belker, A., 1977, VLF mapping of geological structure: Geological Survey of Canada Paper 76-25, 13 p.

Theis, C.V., 1935, Relation between the lowering of the piezometric surface and the rate and duration of discharge of a well using ground-water storage: American Geophysical Union Transactions, part 2, p. 519-524.

1963, Estimating the transmissibility of a water-table aquifer from the specific capacity of a well, in Bentall, Ray, compiler, Methods of determining permeability, transmissibility, and drawdown: U.S. Geological Survey Water-Supply Paper 1536-I, p. 332-336.

Thomas, M.P., 1966, Effect of glacial geology on the time distribution of streamflow in eastern and southern Connecticut: U.S. Geological Survey Professional Paper 550-B, p. B209-B212.

U.S. Environmental Protection Agency, 1988, National Priority List for uncontrolled hazardous waste sites, proposed rule, 40 CFR, Part 300: Federal Register, v. 53, no. 122 , p. $23988-23998$.

-.--- 1989, National Priorities List for uncontrolled hazardous waste sites, final rule; 40 CFR, Part 300: Federal Register, v. 54 , no. 191 , p. $141015-41038$. 
1992, Final rule, National primary and secondary drinking water regulations-Synthetic organic chemicals and inorganic chemicals: U.S. Federal Register, v. 57, no. 138 , July 17,1992 , p. $31,776-31,849$.

1994, Superfund progress at National Priority List sites, Connecticut 1994 update: U.S. Environmental Protection Agency, Region 1, duplicated Publication Information Booklet.

VanderKwaak, J.E., and Sudicky, E.A., 1993, Numerical simulation of NAPL dissolution and aqueous-phase contaminant plume formation and remediation in discretelyfractured porous media [abs.]: Geological Society of America, 1993 annual meeting program with abstracts, p. A-487.

Verschueren, K., 1983, Handbook of environmental data on organic chemicals: New York, Van Nostrand Reinhold, $1310 \mathrm{p}$.

Vogel, T.M., Criddle, C.S., and McCarty, P.L., 1987, Transformations of halogenated aliphatic compounds: Environmental Science and Technology, v. 21, no. 8 , p. 722-836.

Weddle, T.K., Stone, B.D., Thompson, W.B., Retelle, M.J., Caldwell, D.W., and Clinch, J.M., 1989, Illinoian and late Wisconsinan tills in eastern New England--a transect from northeastern Massachusetts to westcentral Maine, with a section on Till stratigraphy of southern New England by B.D. Stone, in Berry, A.W., ed., New England Intercollegiate Geological Conference, 81st annual meeting, Farmington, Maine, Oct. 13-15, 1989, Guidebook for field trips in southern and west-central Maine: Farmington, Maine, University of Maine, p. 25-85.
Weiss, L.A., Bingham, J.W., and Thomas, M.P., 1982, Water resources inventory of Connecticut, part 10, lower Connecticut River basin: Connecticut Water Resources Bulletin 31, $85 \mathrm{p}$.

Williams, J.H., and Conger, R.W., 1990, Preliminary delineation of contaminated water-bearing fractures intersected by open-hole bedrock wells: Ground Water Monitoring Review, v. 10, no. 4, p. 118126.

Works Progress Administration for Connecticut, 1938, Records of wells, springs, and ground-water levels in the town of Berlin, Cromwell, Durham, Meriden, Middlefield, Middletown, Portland, and Wallingford, Connecticut: Connecticut Ground Water Survey Bulletin GW-4, $171 \mathrm{p}$.

Wright, D.L., Olhoeft, G.R., Hsieh, P.A., Majer, E.L., Paillet, F.L., and Lane, J.W., Jr., in press, Electromagnetic and seismic tomography compared to borehole acoustic televiewer and flowmeter logs for subsurface fracture mapping at the Mirror Lake site, New Hampshire, in Morganwalp, D.W., and Aronson, D.A., eds., U.S. Geological Survey Toxic Substances Hydrology Program--Proceedings of the 6th technical meeting, Colorado Springs, Colorado, September 20-24, 1993: U.S. Geological Survey Water-Resources Investigations Report 93-4014. 


\section{APPENDIX 1: Borehole-Geophysical Logs}

(See fig. 8 for well locations and fig. 10 for interpreted lithologic logs.) 


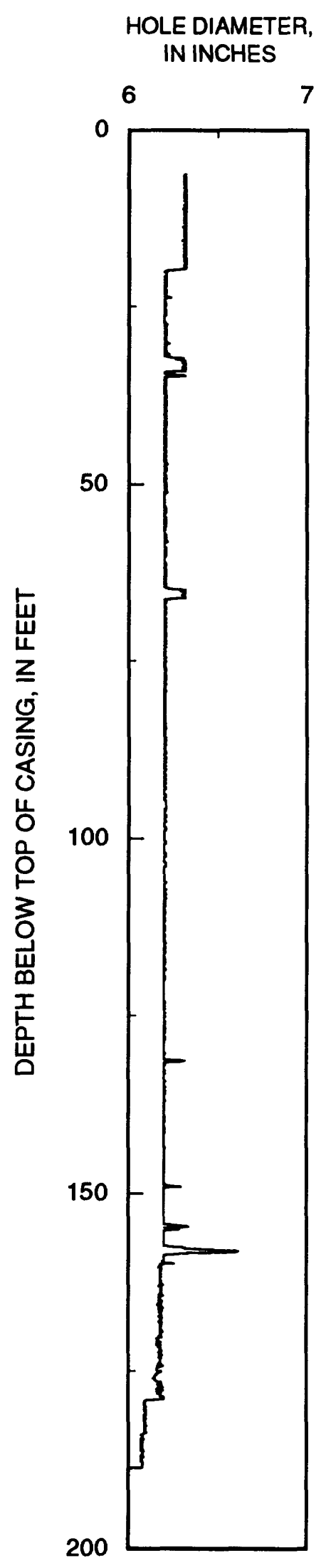

NATURAL GAMMA, IN API UNITS

o 100200300

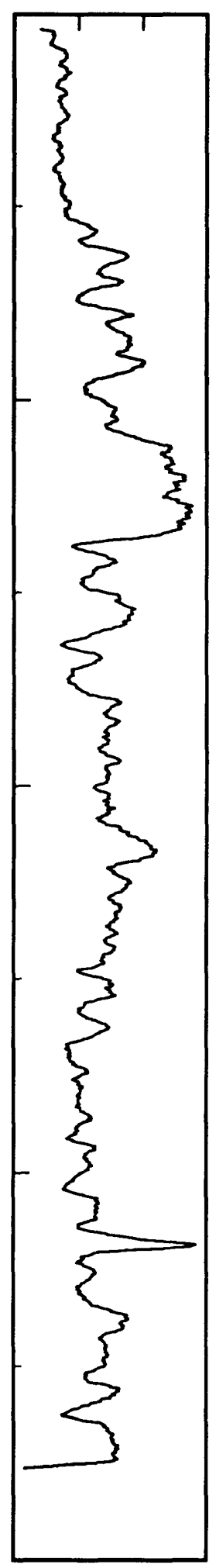

FLUID RESISTIVITY, IN OHM-METERS

$\begin{array}{llll}30 & 35 & 40 & 45\end{array}$

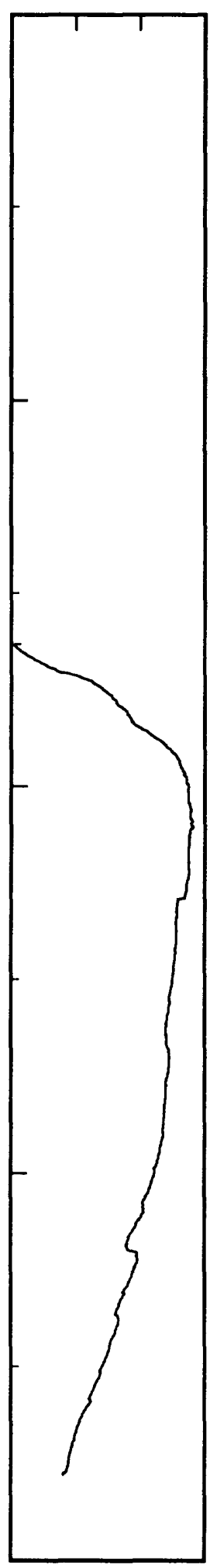

TEMPERATURE, IN DEGREES CELSIUS

11 12

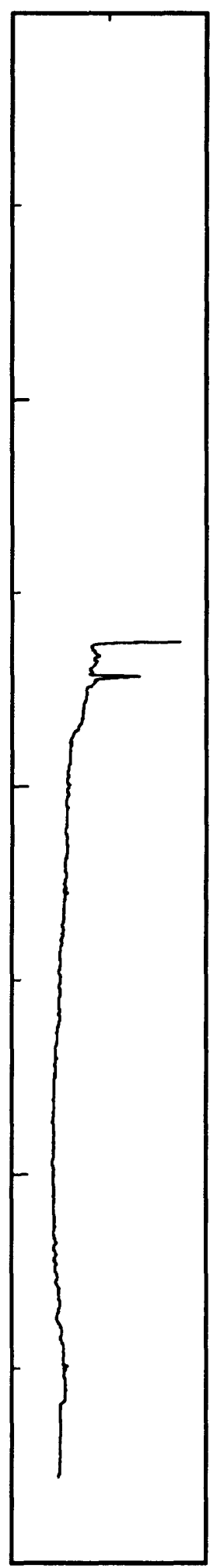




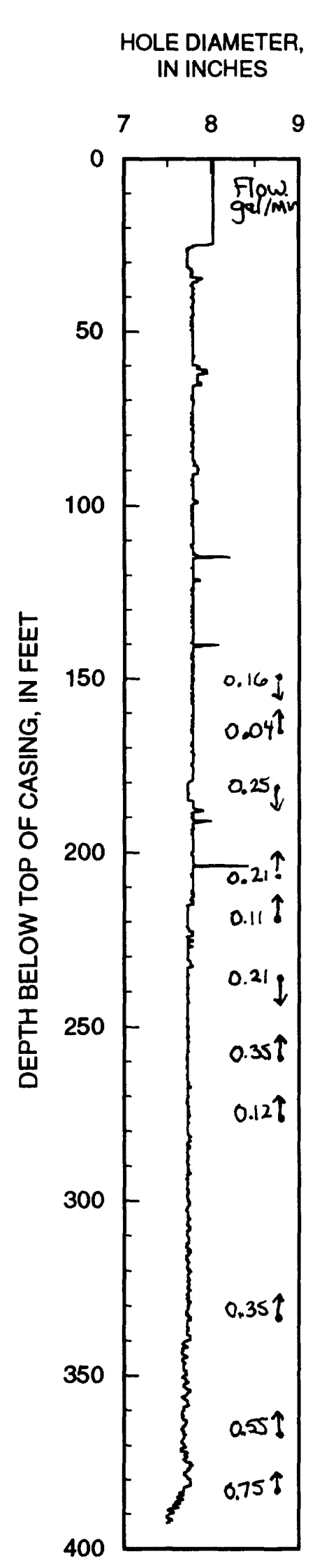

ACOUSTIC

AMPLITUDE,

IN MILLIVOLTS

$\begin{array}{llll}-800-400 \quad 0 \quad 400 & 0\end{array}$

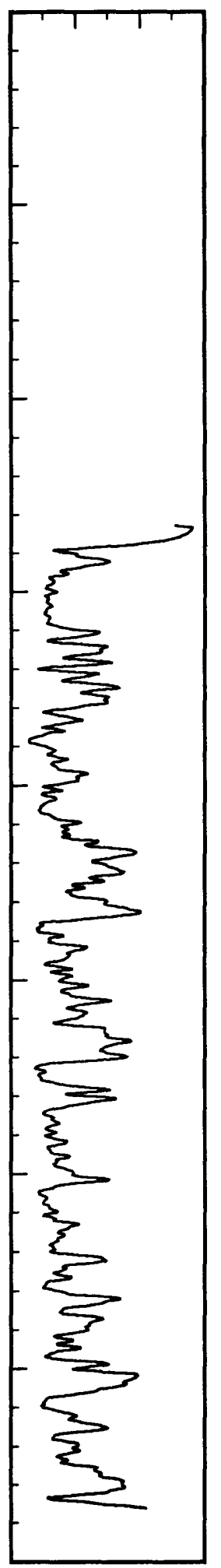

ACOUSTIC VELOCITY, IN MICROSECONDS

PER FOOT
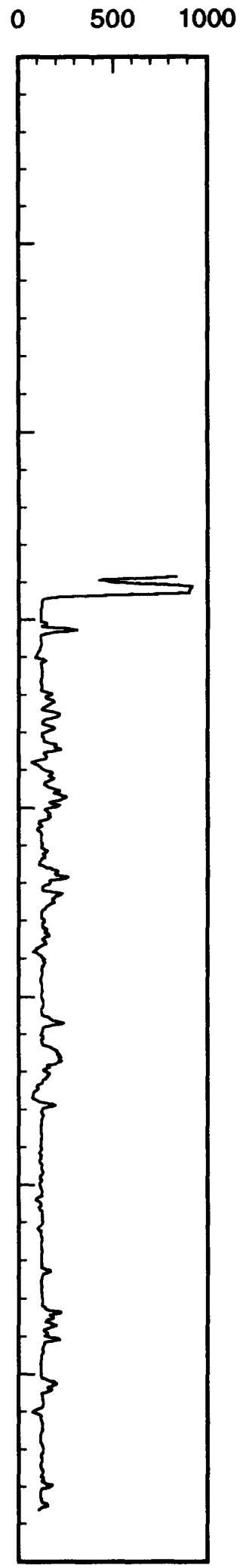


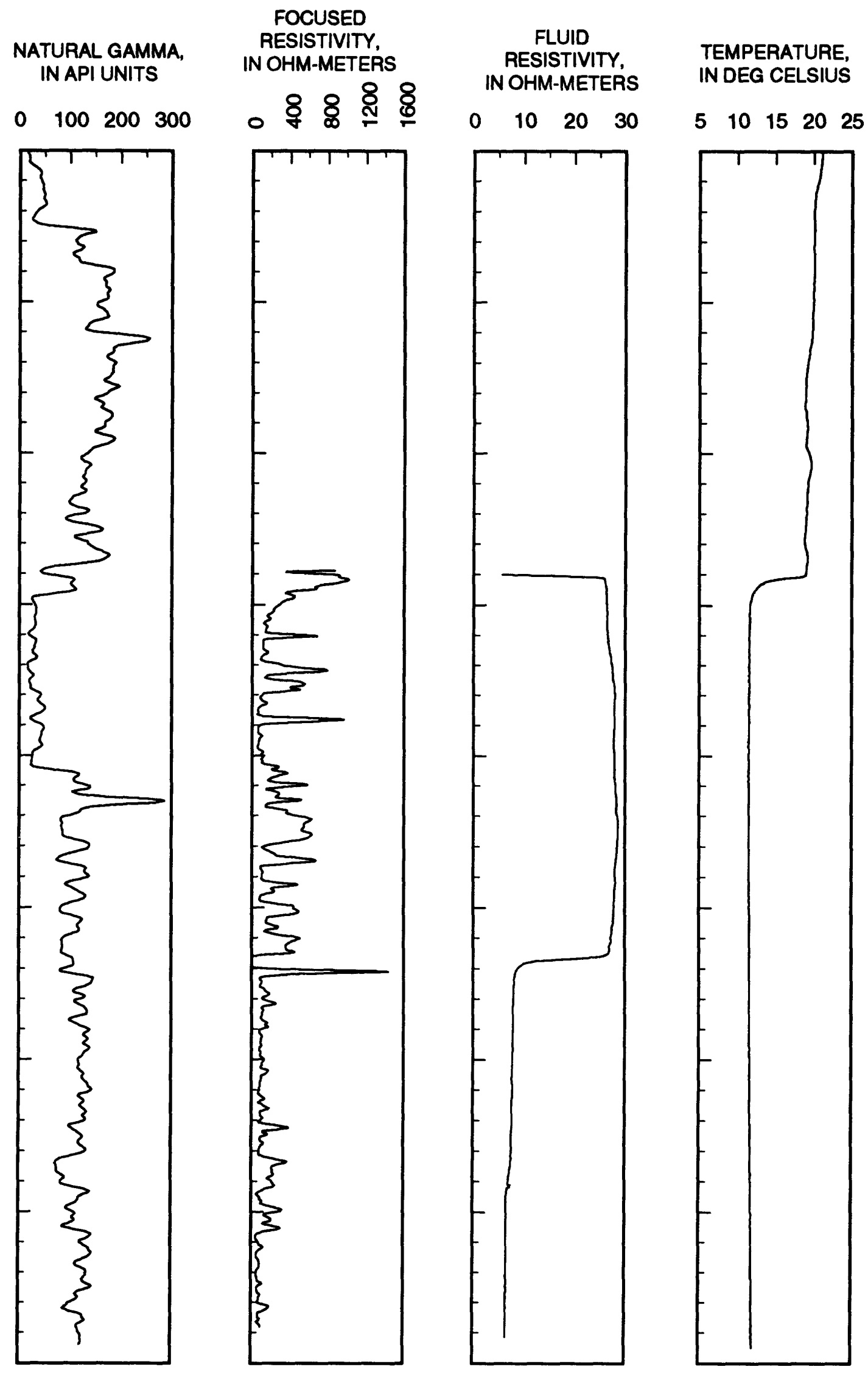

WELL D-129 


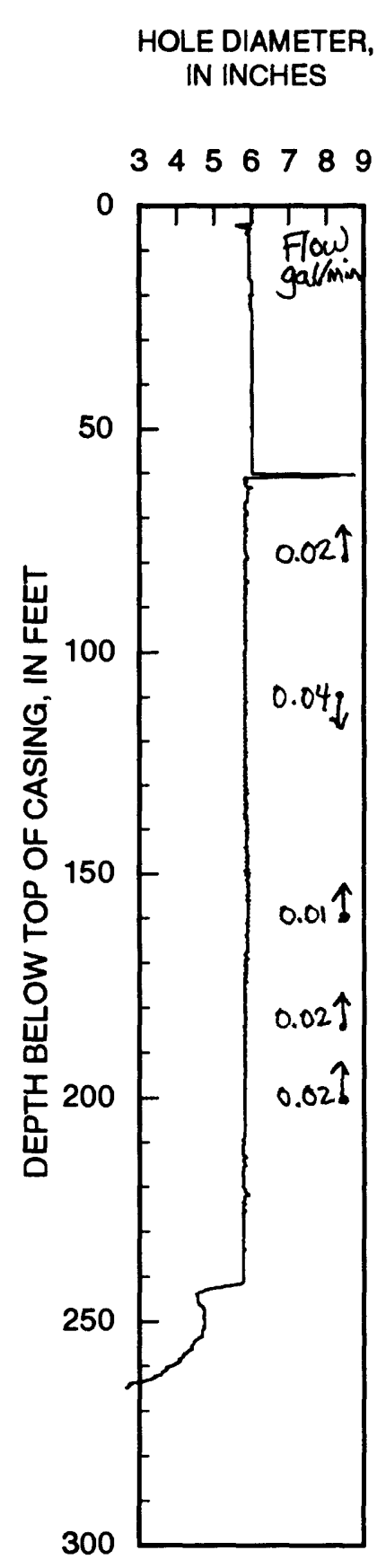

ACOUSTIC VELOCITY, IN MICROSECONDS PER FOOT
FLUID RESISTIVITY, IN API UNITS
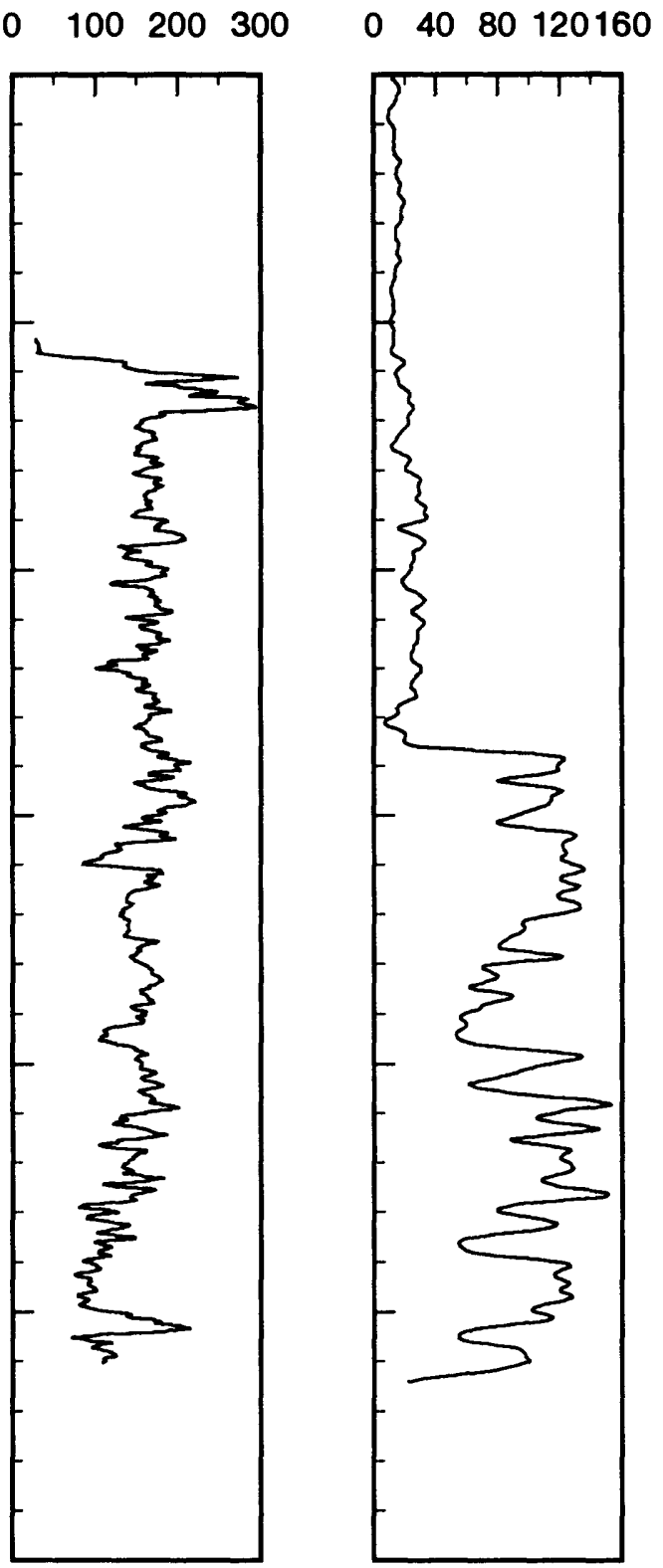
IN OHM-METERS

TEMPERATURE, IN DEGREES CELSIUS $\begin{array}{lllll}0 & 1020304050 & 10 & 11 & 12\end{array}$
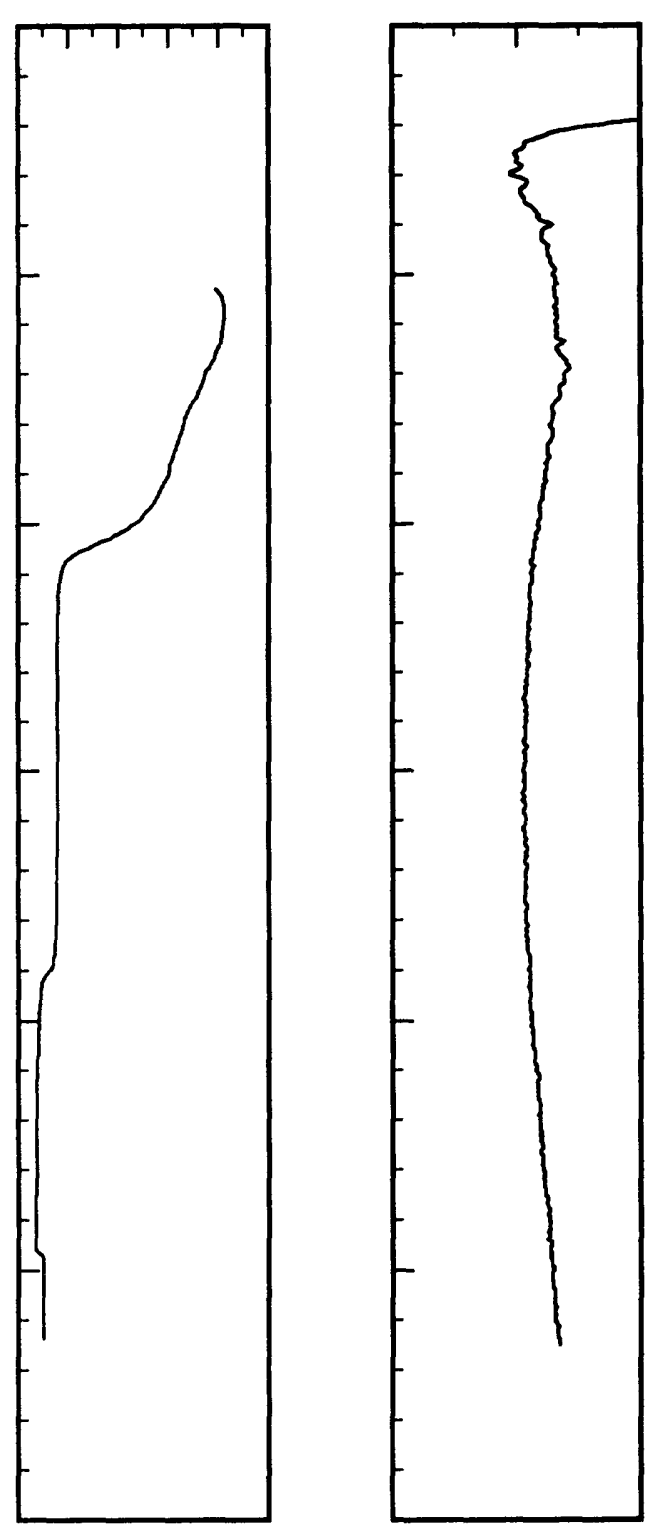

WELL D-138 

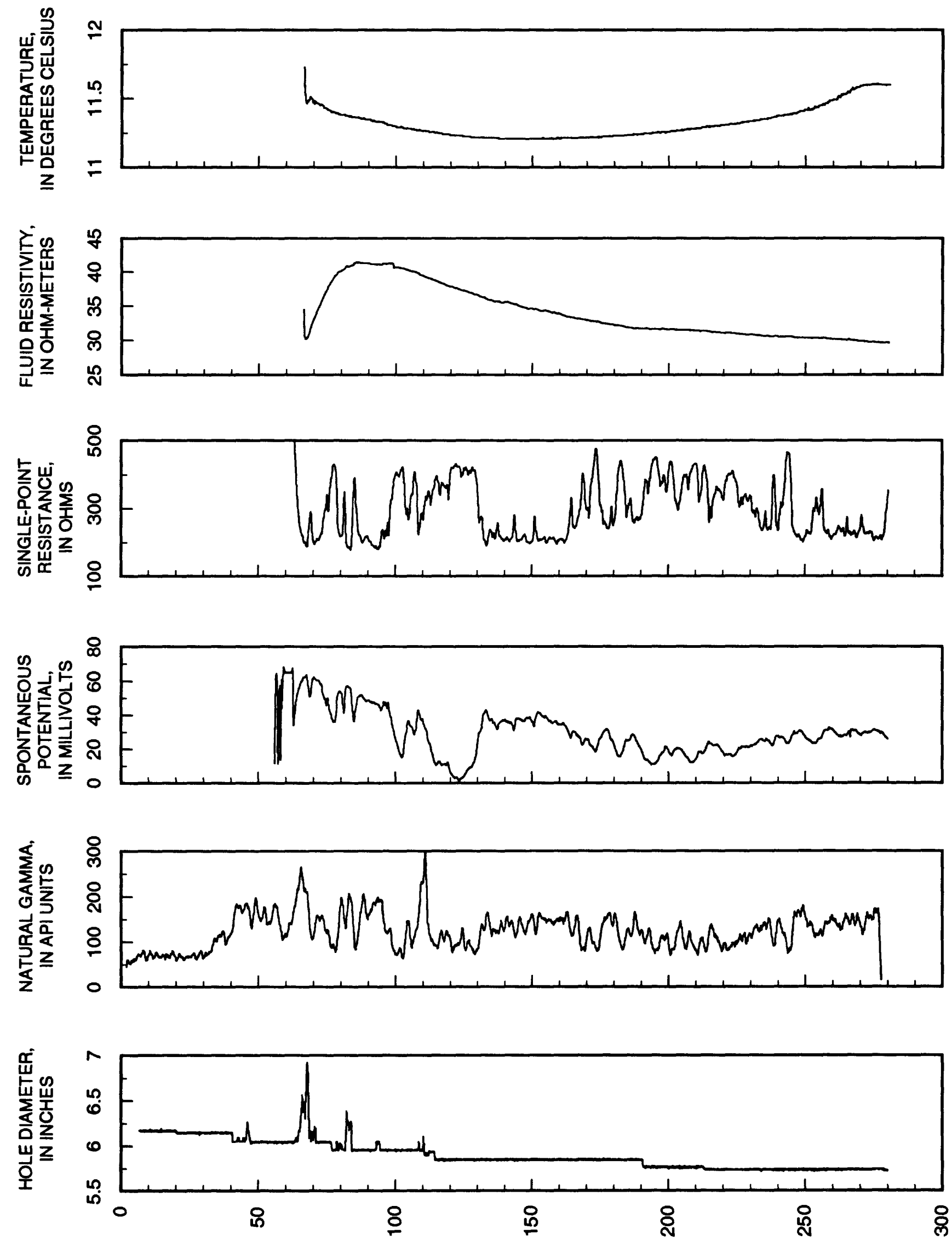

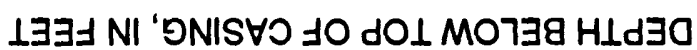



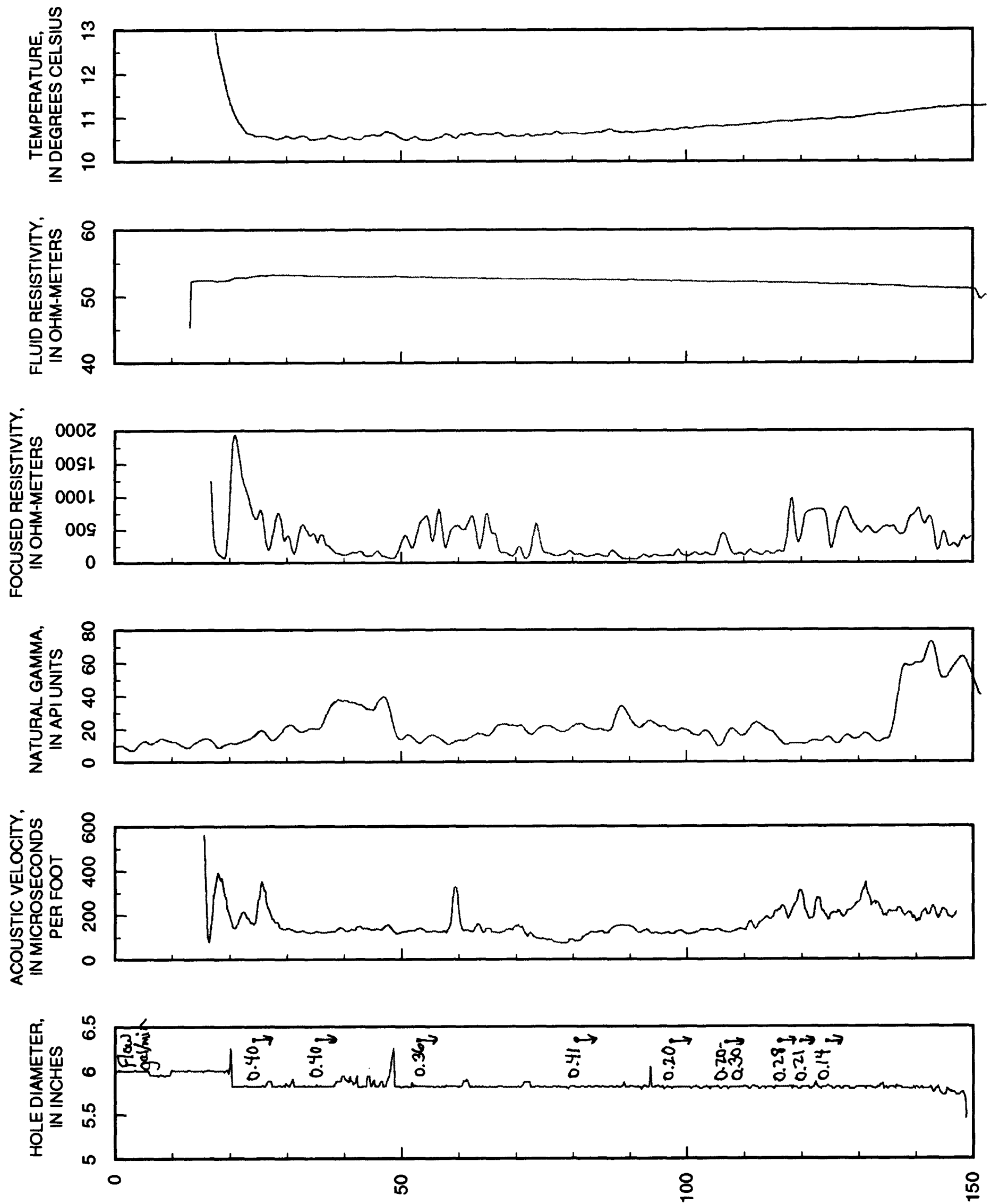


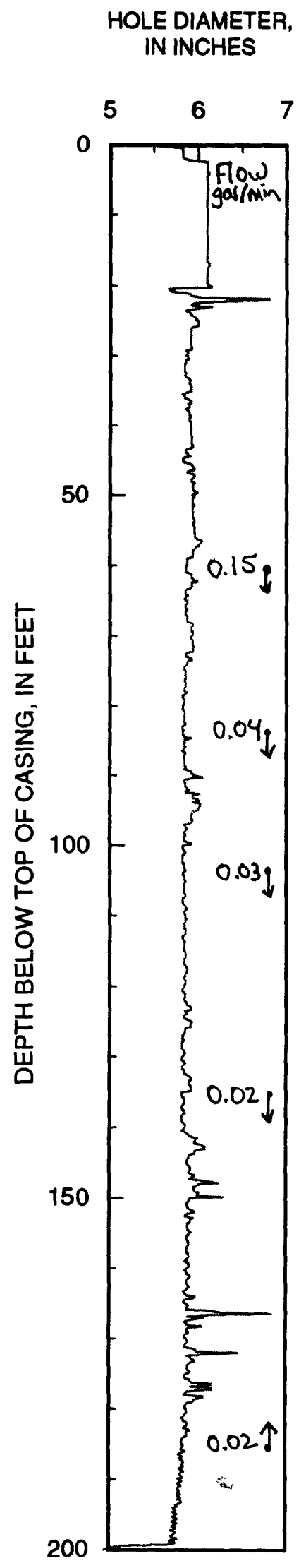

AMPLITUDE,

IN MILLIVOLTS

$\begin{array}{rrrr}-800 & -400 \quad 0 \quad 400\end{array}$

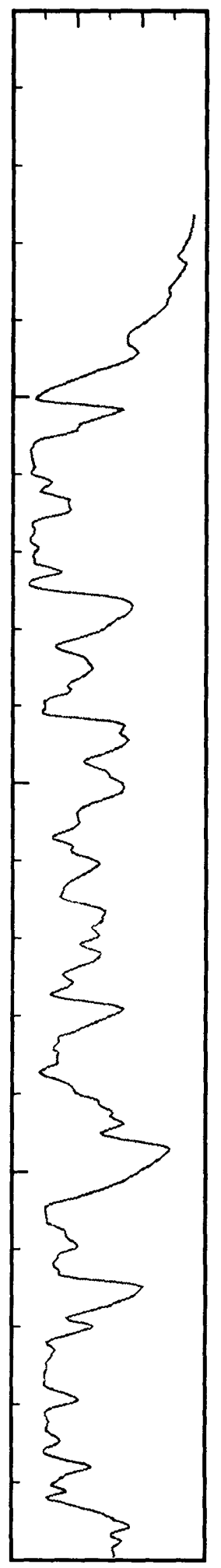

ACOUSTIC VELOCITY, IN MICROSECONDS PER FOOT

$0 \quad 250500750$

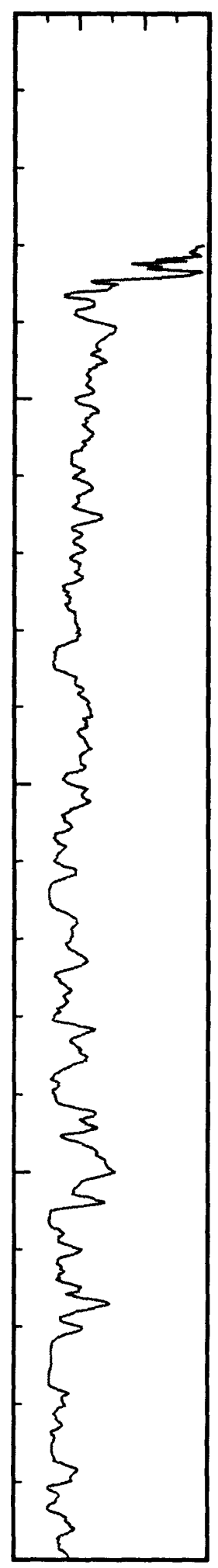

WELL D-149 
NATURAL GAMMA,

IN API UNITS

$0 \quad 40 \quad 80120160$

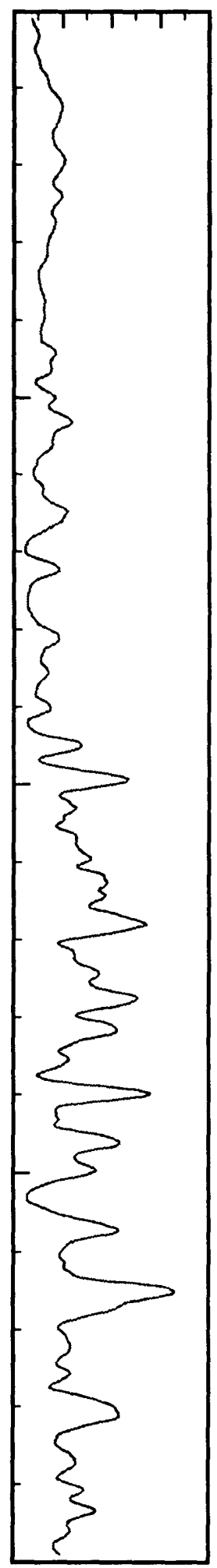

FLUID RESISTIVITY, IN OHM-METERS

$\begin{array}{llll}20 & 25 & 30 & 35\end{array}$

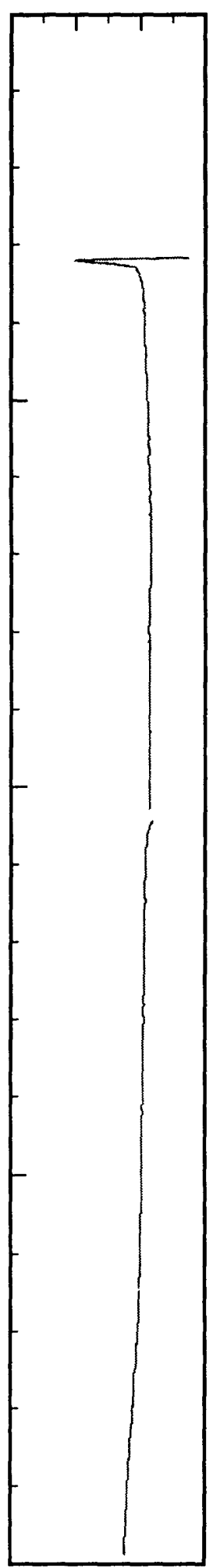

TEMPERATURE, IN DEGREES CELSIUS
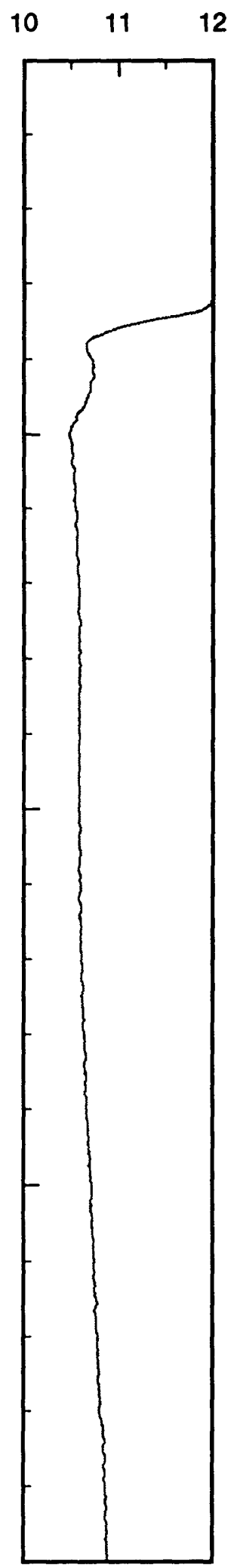

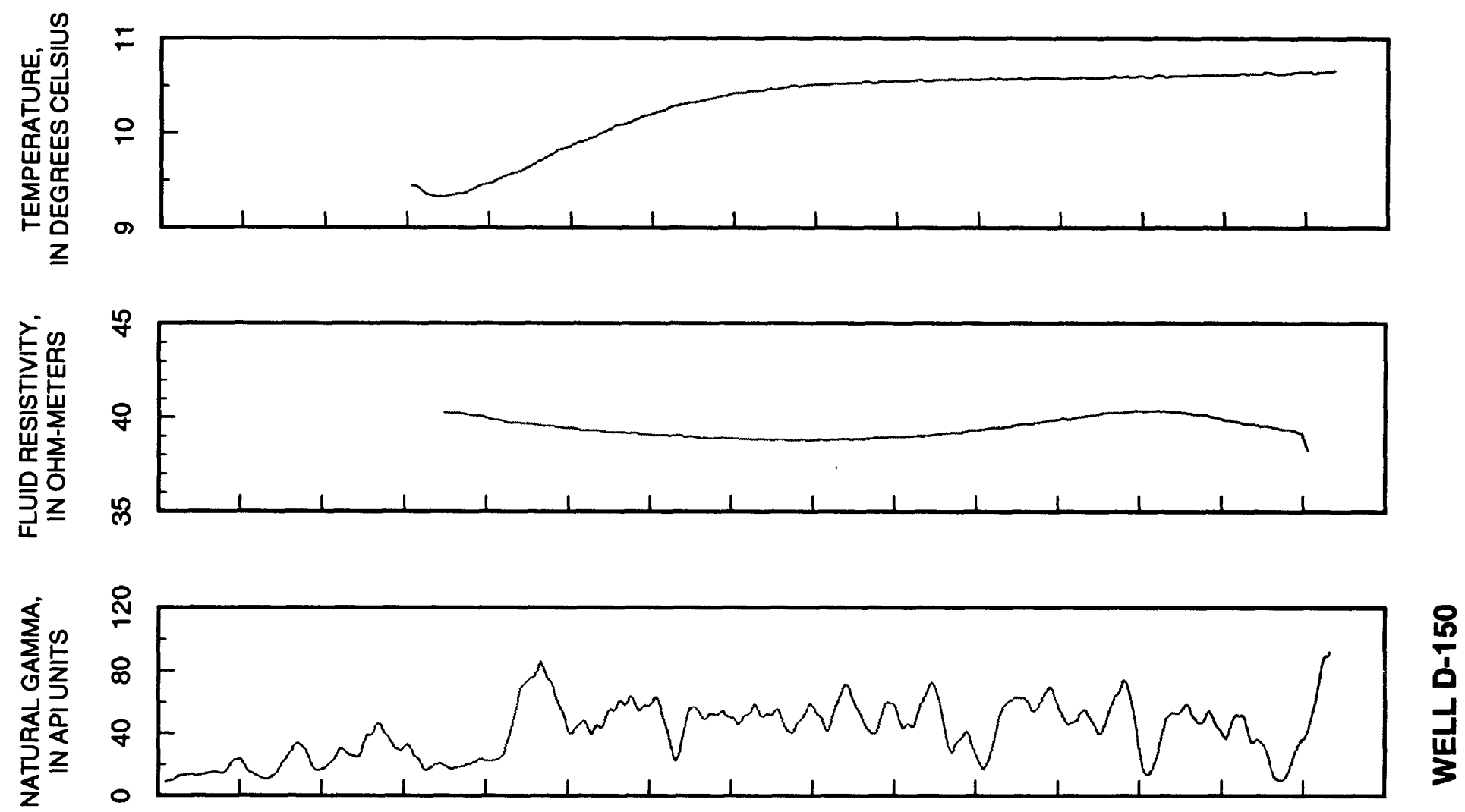

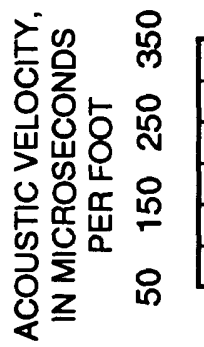
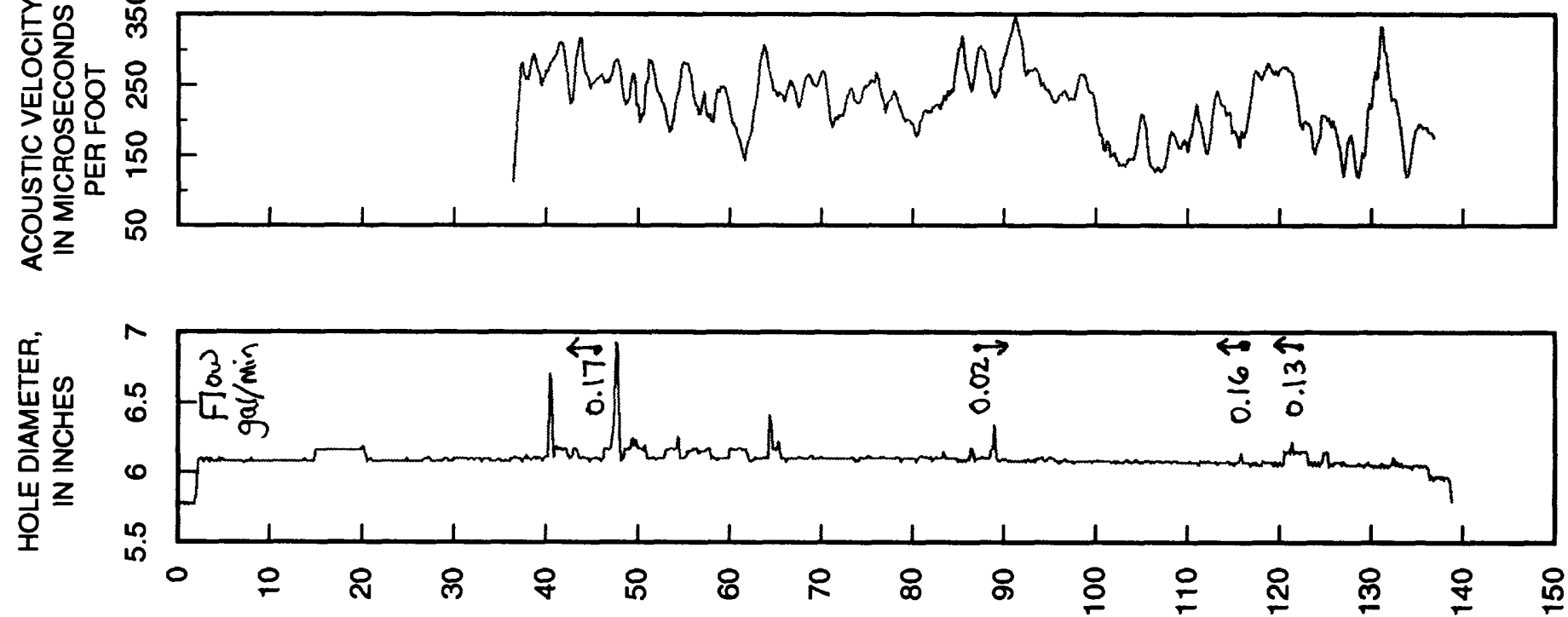

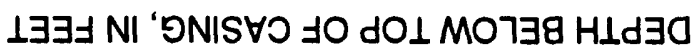



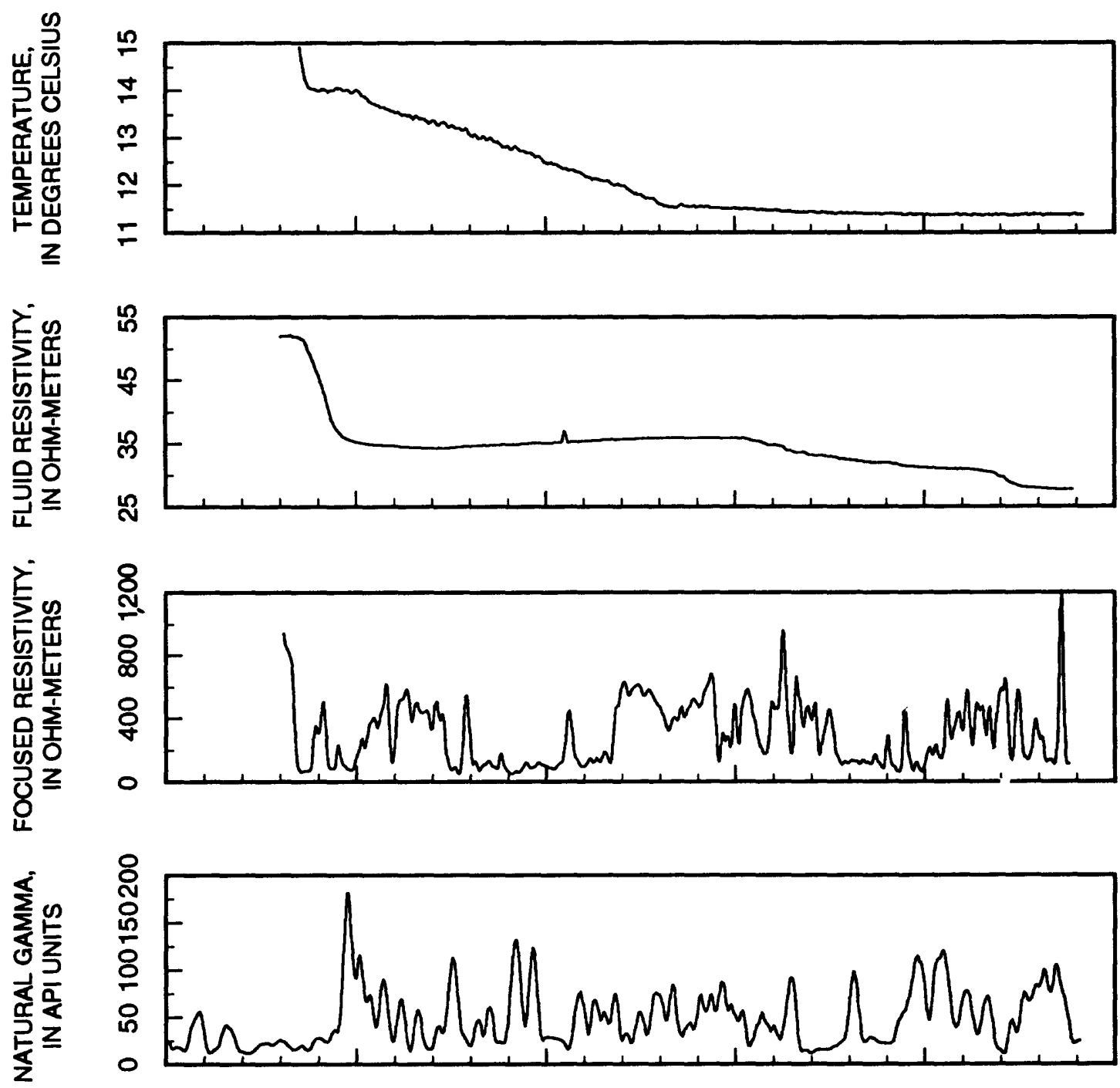

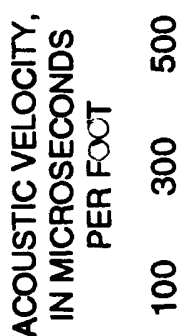
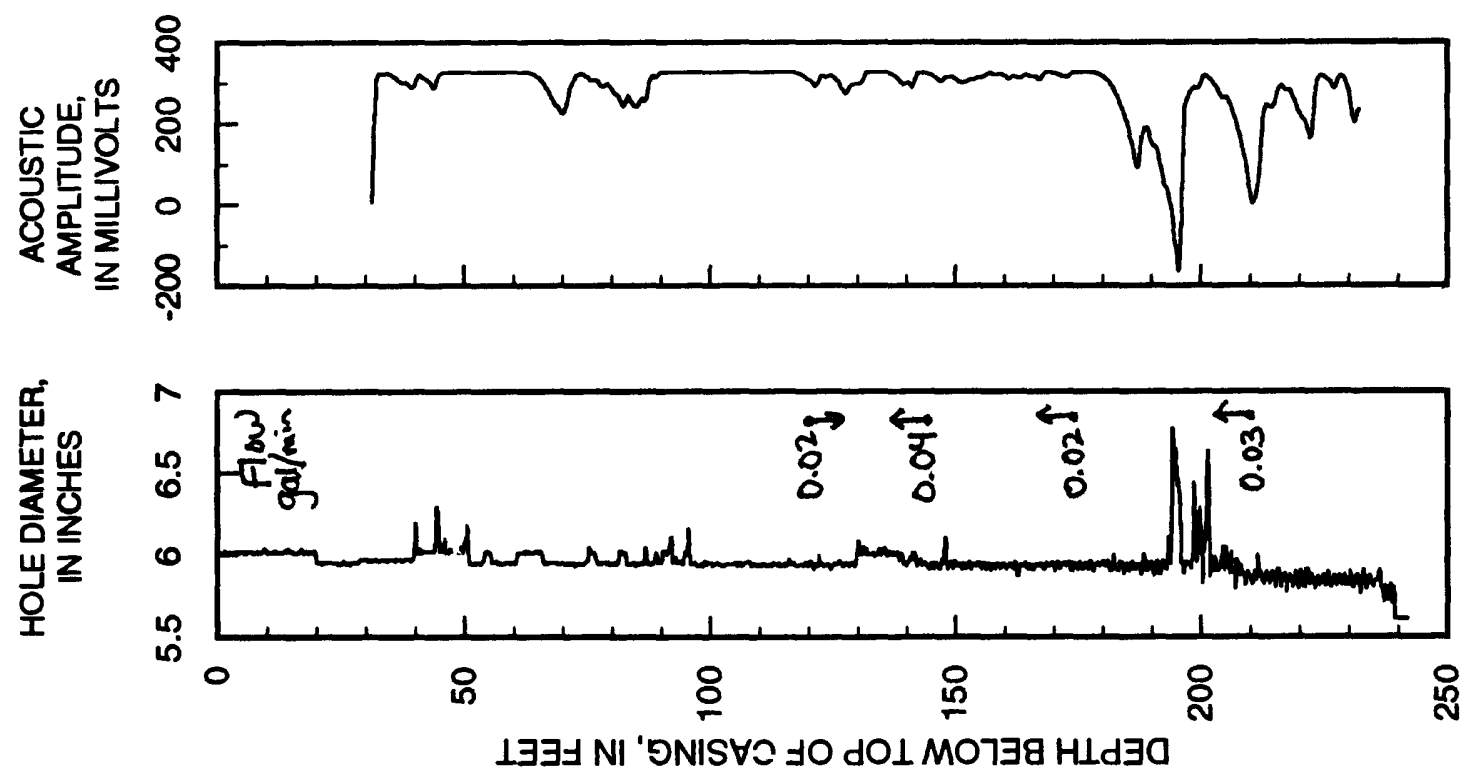


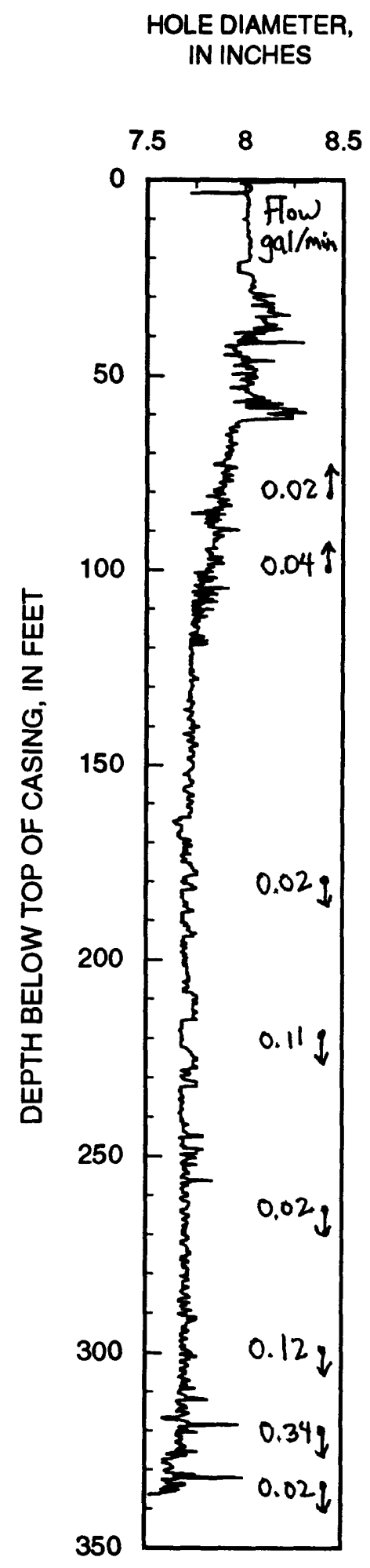

ACOUSTIC

AMPLITUDE,

IN MILLIVOLTS

$\begin{array}{cccc}-800 & -400 & 0 & 400\end{array}$

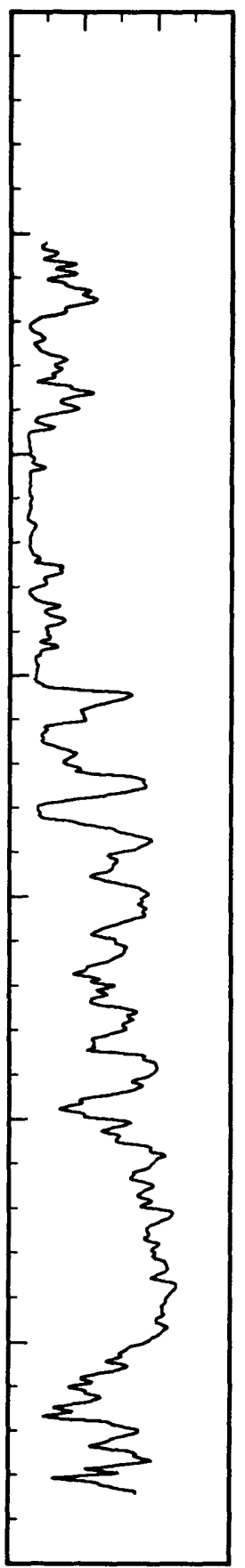

ACOUSTIC VELOCITY, IN MICROSECONDS

PER FOOT

$50 \quad 150 \quad 250$

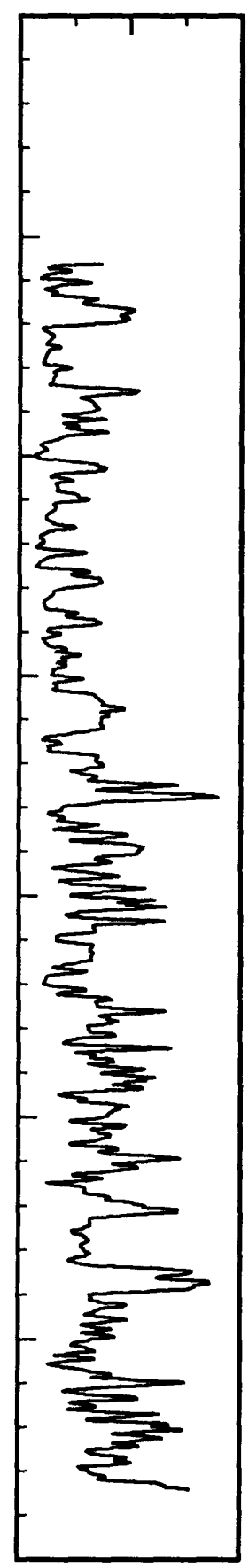



$\begin{array}{ccc}\text { NATURAL GAMMA, } & \text { FOCUSED RESISTIVITY, } & \text { FLUID RESISTIVITY, } \\ \text { IN API UNITS } & \text { IN OHM-METERS } & \text { TEMPERATURE, } \\ \text { IN OHM-METERS } & \text { IN DEGREES CELSIUS }\end{array}$
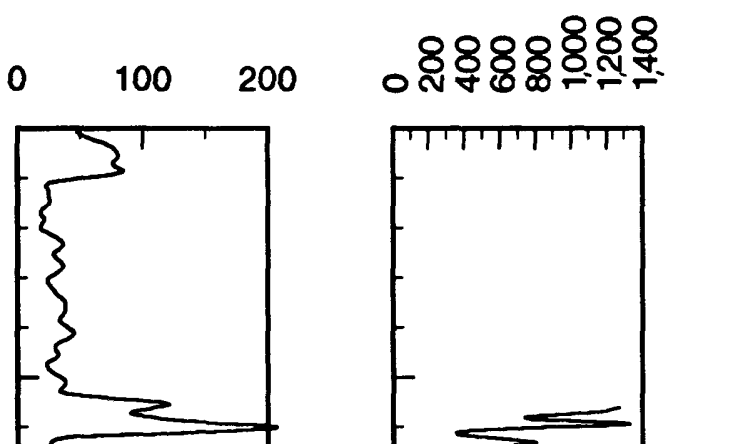

-

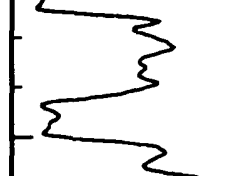

$\sum$

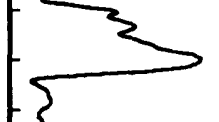

\{

$-\{$ 2

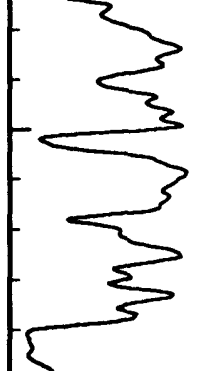

$-$
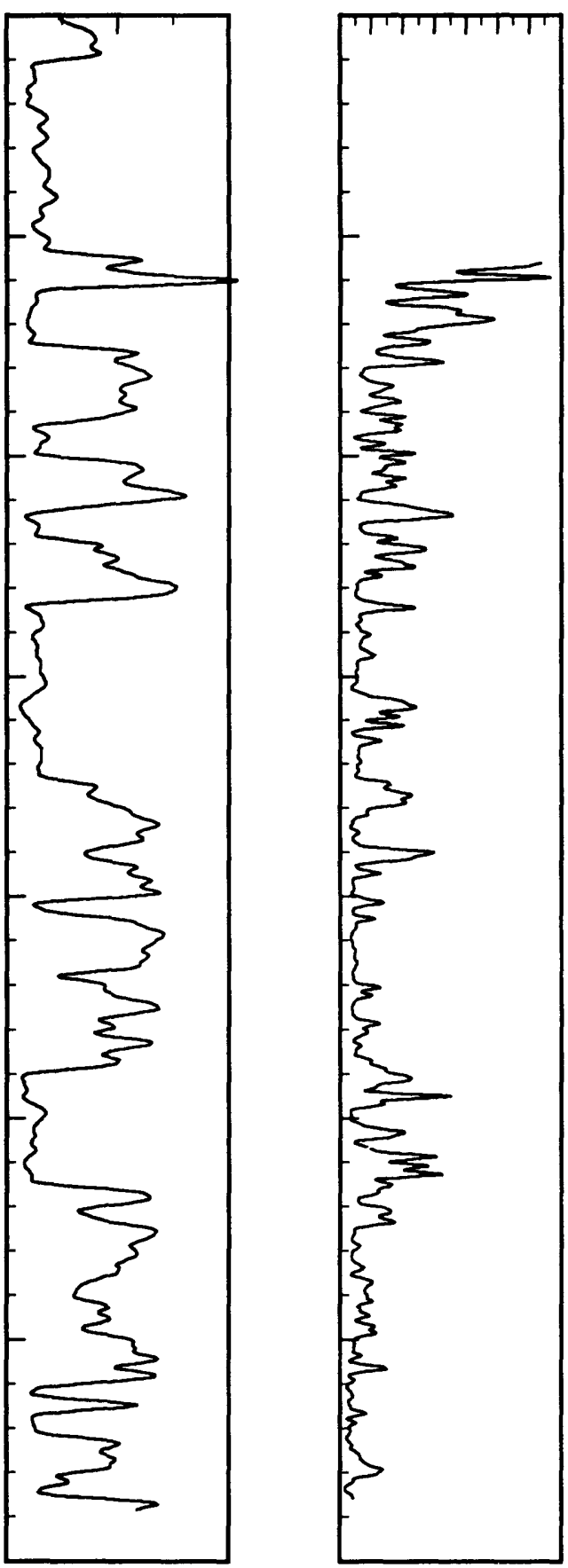

$\begin{array}{llllllll}0 & 10 & 20 & 30 & 11 & 12 & 13 & 14\end{array}$
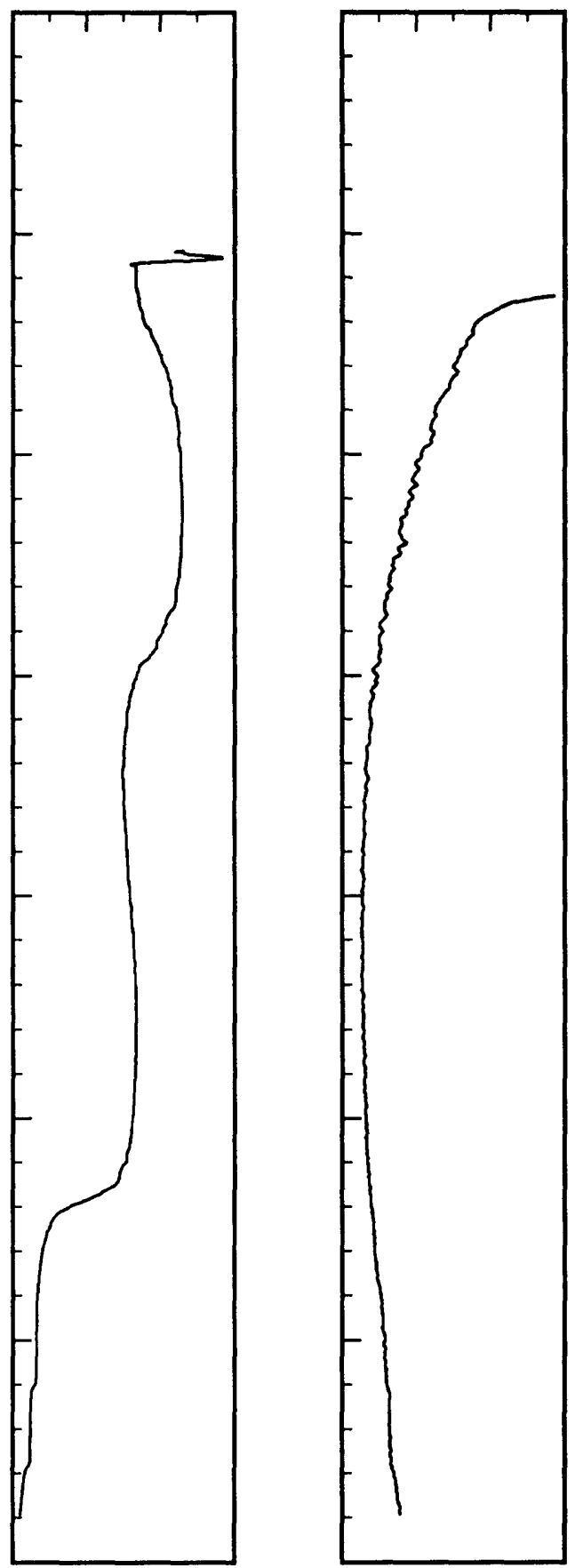

WELL D-157 


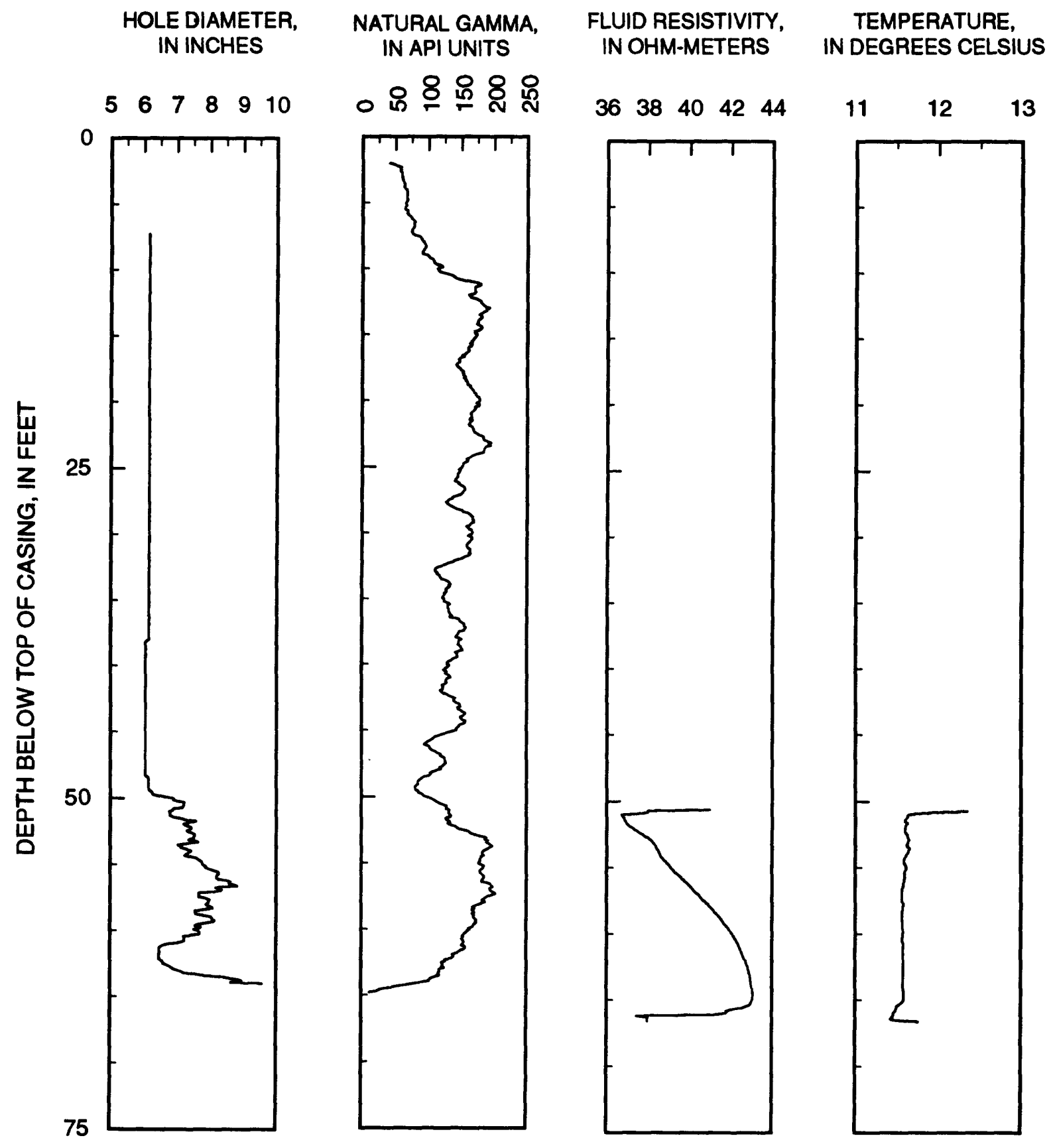

WELL D-178 

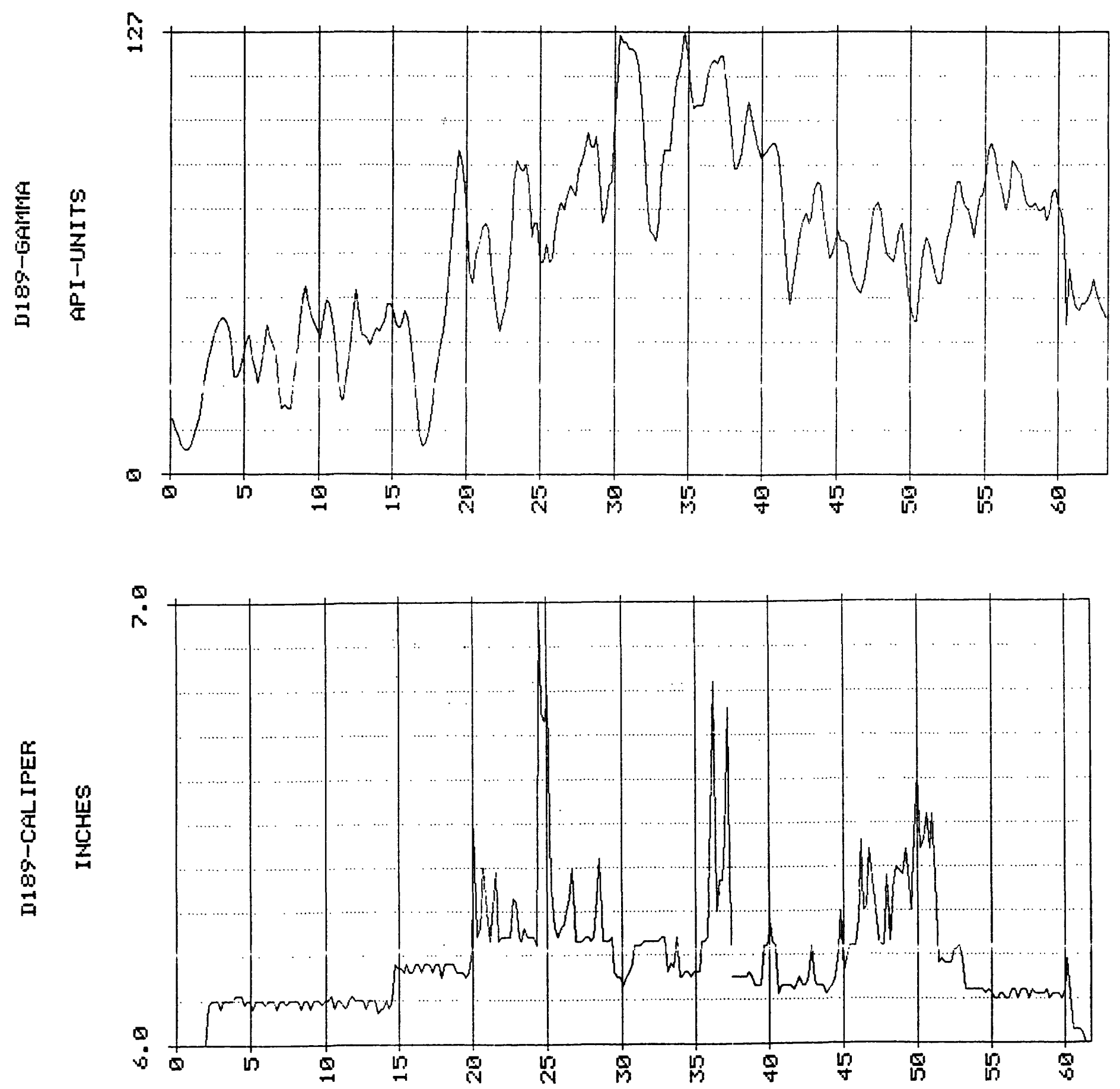

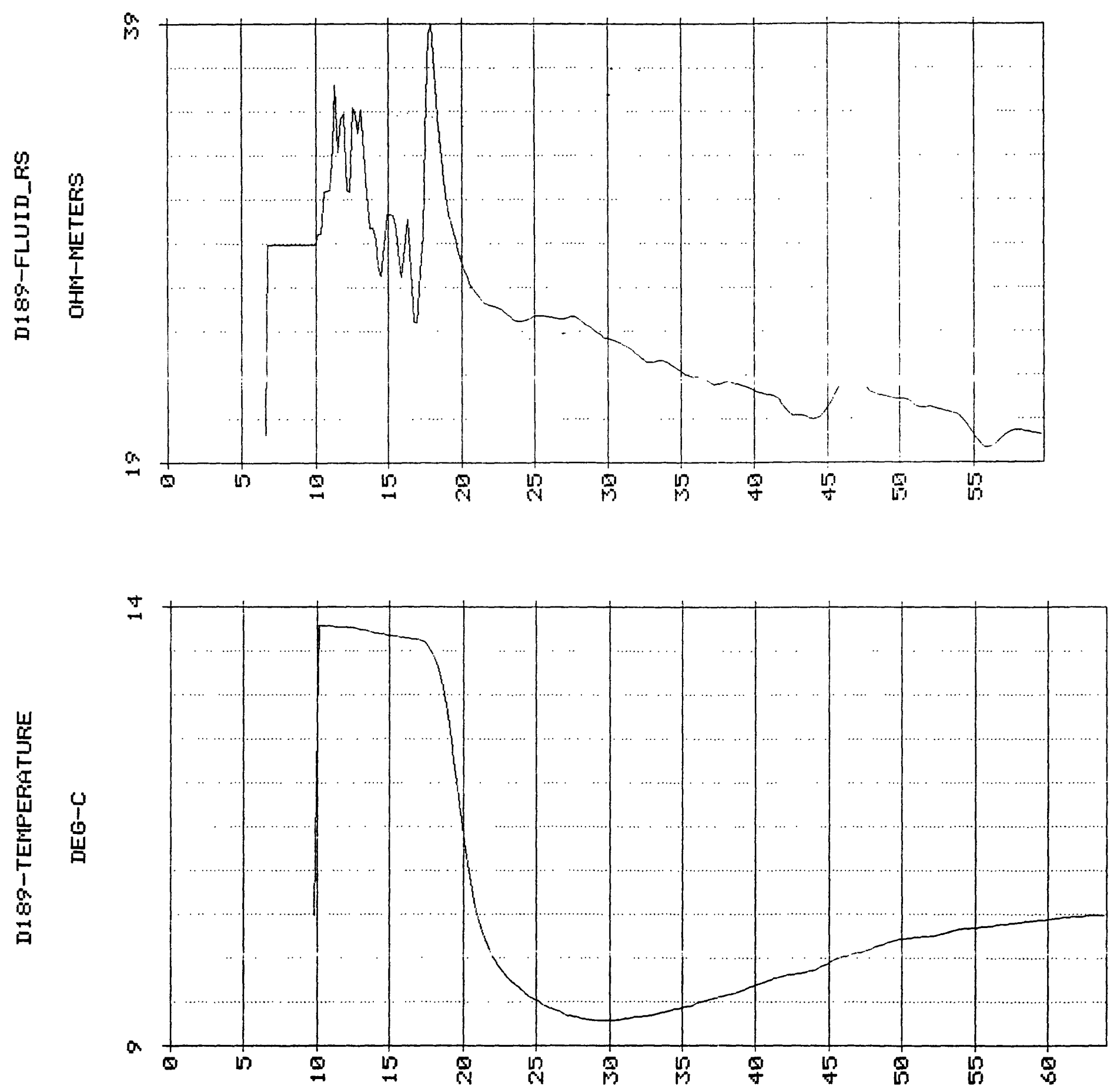

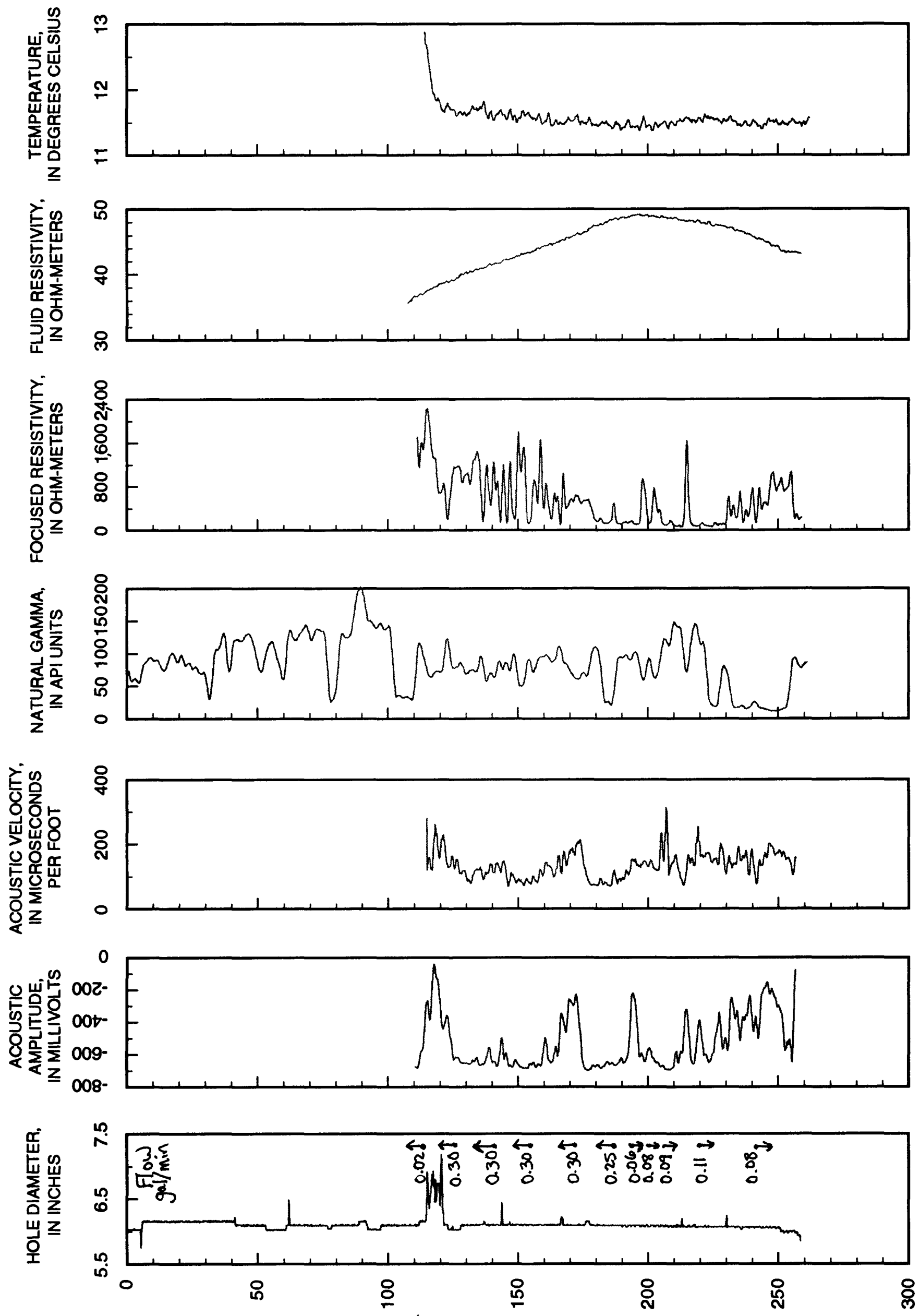
NATURAL GAMMA, FOCUSED RESISTIVITY, FLUID RESISTIVITY, IN API UNITS

0

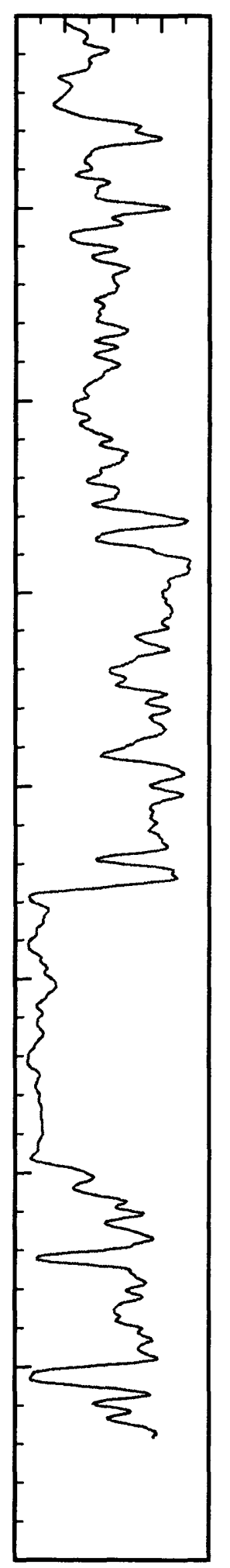

IN OHM-METERS

IN OHM-METERS

$0200400600800 \quad 0 \quad 510152025$
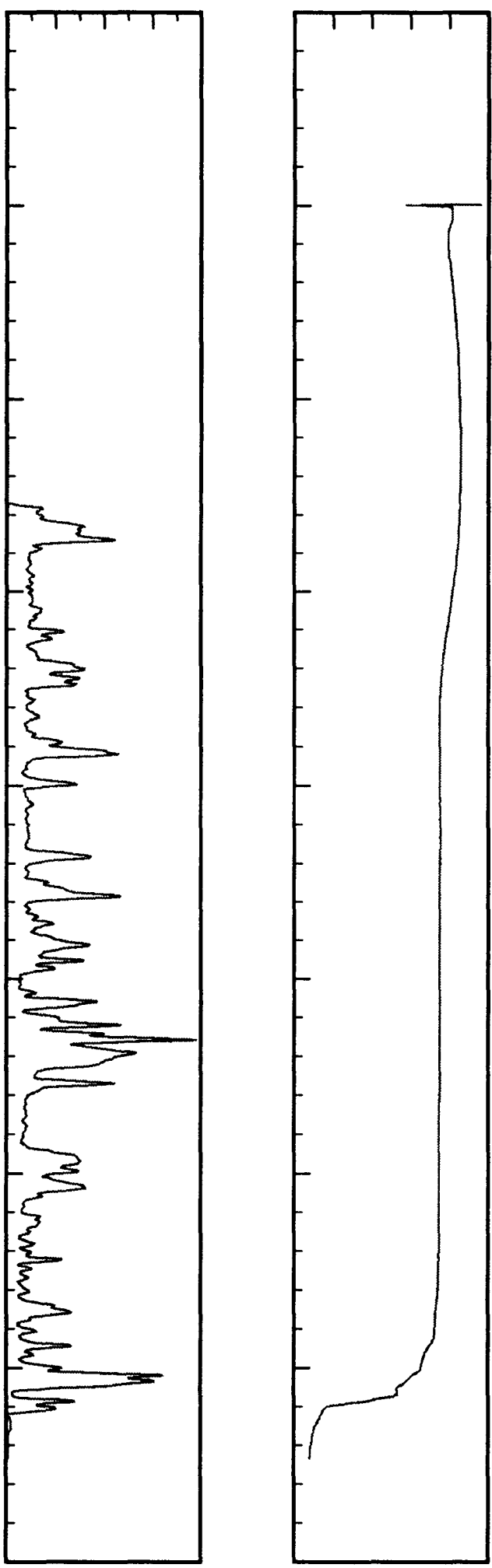

TEMPERATURE,

IN DEGREES CELSIUS

101214161820

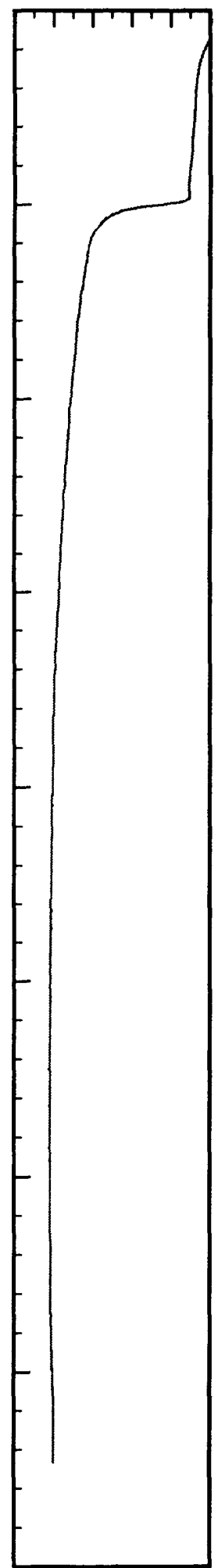

WELL D-191 


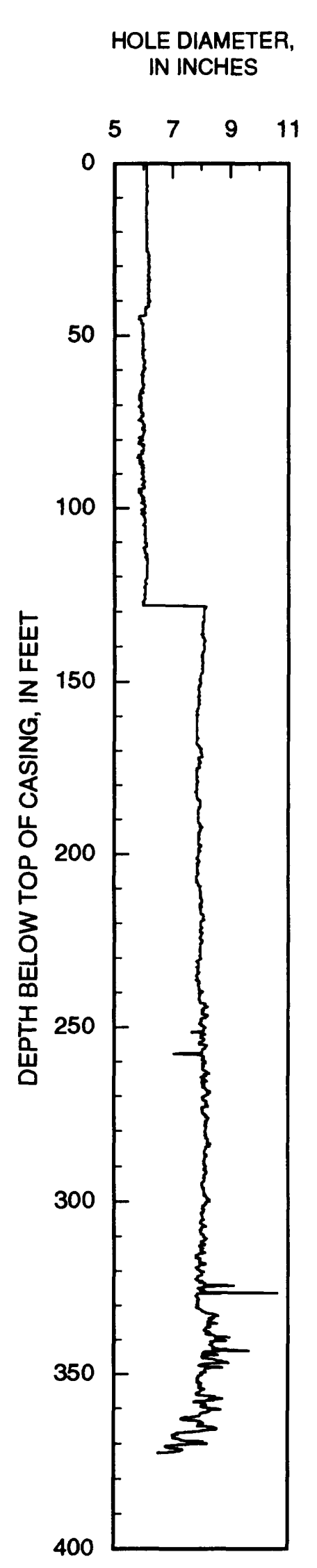

ACOUSTIC

AMPLITUDE,

IN MILLIVOLTS

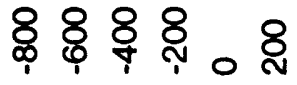

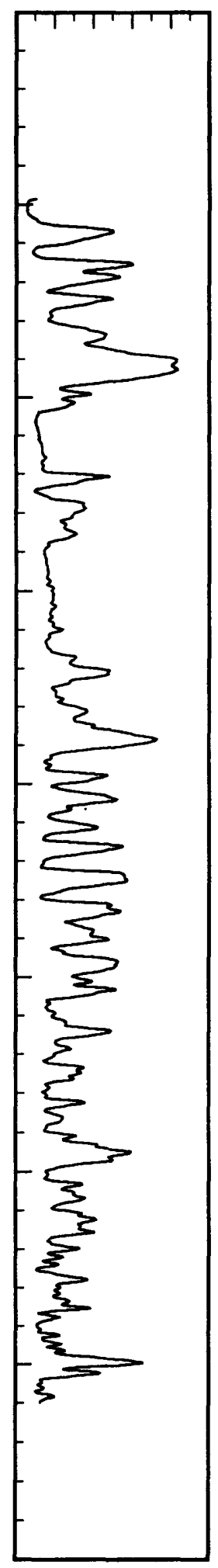

ACOUSTIC VELOCITY, IN MICROSECONDS

PER FOOT
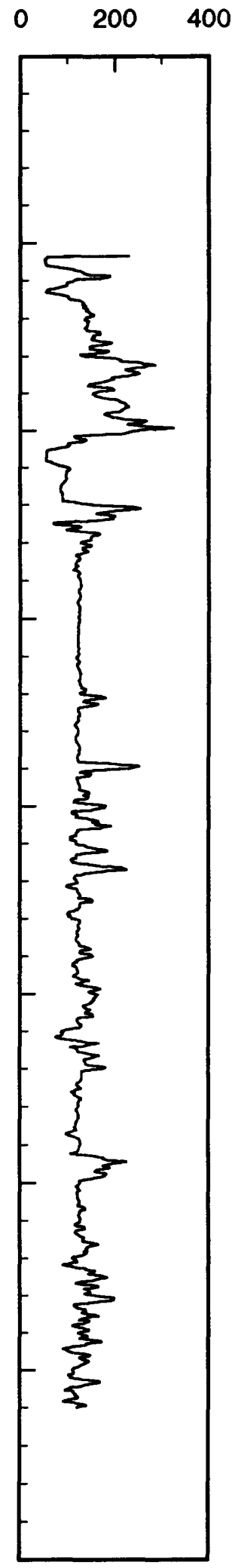